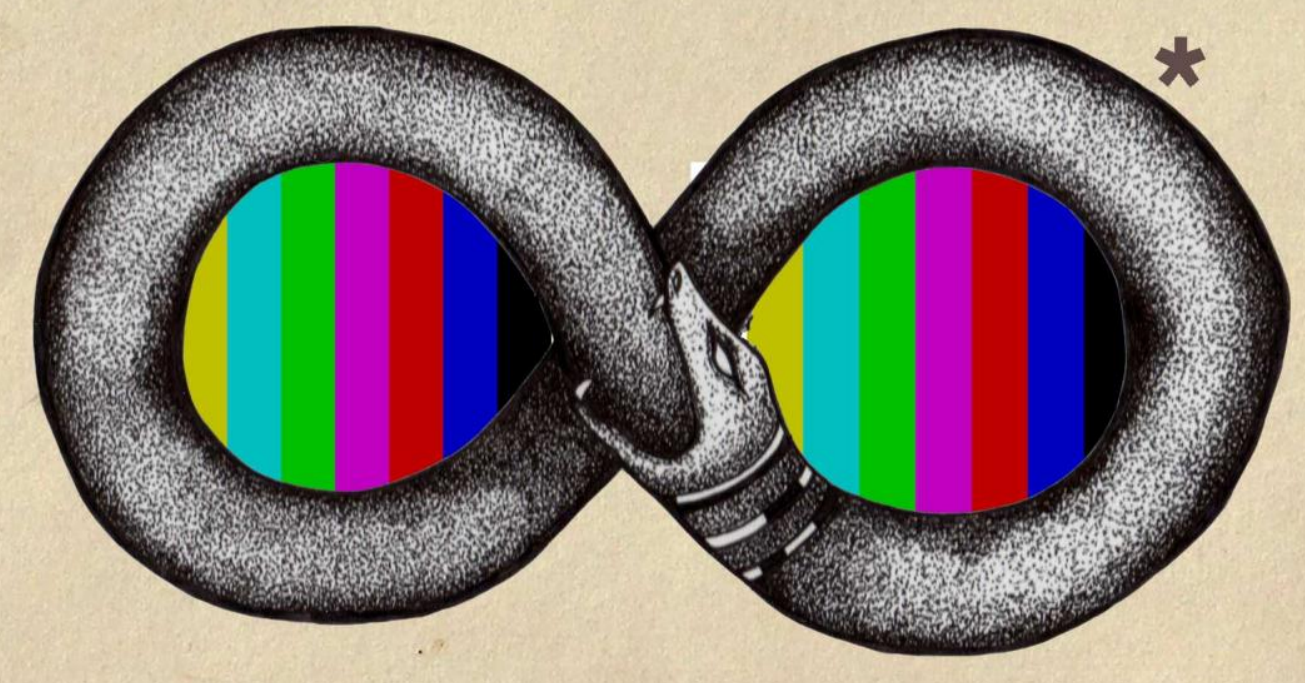

MDN5TRD-MÁ5CHRA5 VIDEGGRÁFICH5: VDNTHOE DE PUTÉNCIA NA LEI DU ETERND RETDRND 


\section{* Ouroboros}

Criatura mitológica em forma de serpente ou dragão que engole a própria cauda por isso simboliza o ciclo da vida, a eternidade, a mudança, o tempo, a evolução, a fecundação, o nascimento, a morte, a ressurreição, a criação, a destruição e a renovação. Figura mitológica e muitas vezes religiosa (conexão entre os homens e Deus), o Ouroboros está presente em muitos textos antigos do Egito, da Grécia, da Índia, do Japão e na cultura asteca. É o símbolo do Deus Romano Janus (Deus do início, das entradas e das escolhas); da serpente bíblica do Jardim do Éden; do símbolo chinês do Ying e Yang e na mitologia nórdica a serpente, “Jörmungandr". No budismo, a Ouroboros simboliza o olhar para si como forma de evoluir espiritualmente, marcado pela ausência de início e fim. Por sua vez, na alquimia é usado como um norteador das estações do ano, dos céus, a partir da representação da serpente que devora a própria cauda, simbolizando, dessa forma, a energia cíclica da vida, a unidade primordial, a totalidade do mundo. 


\author{
Universidade de São Paulo \\ Escola de Comunicação e Artes \\ Departamento de Artes Cênicas
}

WINSTON KURTZ

(ROBERTO GOMES BARBOSA)

\title{
Monstro-máscaras videográficas: Vontade de potência na lei do eterno retorno
}

São Paulo

2014 


\author{
WINSTON KURTZ \\ (ROBERTO GOMES BARBOSA)
}

\title{
Monstro-máscaras videográficas: vontade de potência na lei do eterno retorno
}

Dissertação de Mestrado para a obtenção do Título de Mestre em Artes Cênicas apresentada ao Programa de Pósgraduação em Artes Cênicas da Escola de Comunicação e Artes da Universidade de São Paulo.

Área de concentração: Texto e Cena.

Orientador: Prof. Dr. Felisberto Sabino da Costa

São Paulo

2014 
Autorizo a reprodução e divulgação total ou parcial deste trabalho, por qualquer meio convencional ou eletrônico, para fins de estudo e pesquisa, desde que citada a fonte.

Catalogação na publicação

Serviço de Biblioteca e Documentação

Escola de Comunicação e Artes da Universidade de São Paulo

Dados fornecidos pelo(a) autor(a)

Kurtz, Winston

Monstro-máscaras videográficas: vontade de potência

na lei do eterno retorno / Winston Kurtz. -- São Paulo: W.

Kurtz, 2014.

180 p.: il.

Dissertação (Mestrado) - Programa de Pós-Graduação em Artes

Cênicas - Escola de Comunicações e Artes / Universidade de

São Paulo.

Orientador: Felisberto Sabino da Costa

Bibliografia

1. Máscara teatral 2. máscara videográfica 3. monstro 4.

sociedade prometeica e fáustica 5. teatro multimídia I.

Costa, Felisberto Sabino da II. Título.

CDD 21. ed. -792 
Nome: Winston Kurtz (Roberto Gomes Barbosa)

Título: Monstro-máscaras videográficas. Dissertação apresentada ao curso de pós-graduação em Artes Cênicas da Escola de Comunicação e Artes para a obtenção do título de Mestre em Artes Cênicas.

Aprovado em: 
À minha esposa Viviane pela paciência, sabedoria e compreensão que tornou um sonho em realidade; e aos meus pais, Manoel e Lucy, que transformaram uma realidade em sonho. 


\section{AGRADECIMENTOS}

Minha infinita gratidão, amor e respeito a minha companheira Viviane Rin pela constante compreensão, paciência e apoio nas horas difíceis, indispensáveis para a conclusão deste trabalho.

Aos meus pais Manoel Pessoa Barbosa e Lucy Gomes Barbosa que despertaram no filho o gosto pela leitura e a curiosidade pela pesquisa.

A Jorge Garcia Piñero pela ajuda providencial e preciosa nas traduções desta dissertação.

A professora Helena Bastos que me apresentou as multiplicidades e subjetividades do corpo em sua disciplina. Além da confiança em meu trabalho ao me admitir como estagiário e me proporcionar grandes conhecimentos.

A professora Marília Franco que ampliou o meu horizonte pedagógico audiovisual com suas aulas objetivas e estimulantes.

Ao professor Luis Fernando Ramos com sua contagiante aula e conhecimentos filosóficos que proporcionaram um caminho melhor para este trabalho.

Aos professores Almir Almas e Marcelo Denny com seus pensamentos híbridos, conhecimentos múltiplos e visão de mundo que não só proporcionaram um crescimento profissional, mas pessoal.

Aos professores da PUC-SP, Rubens Fernandes Jr., Sergio Basbaum, Lia Chaia, Rosangella Leote, Nelson Brissac, Maria Candida de Almeida Castro e Lucia Santaella que me apresentaram a um mundo pós-humano, tecnológico e fomentaram a base desta dissertação.

Aos amigos Michel Mauch, Juliana Pedreira, Marcucci, Caio Fernandes, Rafael Rios, Jonas de Moraes, Fabio Medeiros, Leonel Carneiro, Ipojucan Pereira, Eli Ridolfi, por suas conversas construtivas e enriquecedoras ao longo de todo este período.

Aos alunos do primeiro ano da graduação de Artes Cênicas (2013) pelo seu afeto e disposição. A professora Patricia Moran por compartilhar sua visão de mundo. A Steve Dixon, pela performatividade afetiva. A Otávio Donasci e Denis Marleau pela disponibilidade, acolhida, dom visionário e talento. 
Ao Capes pela concessão da bolsa, vital para a continuidade de todo processo de trabalho.

A todos os funcionários da pós-graduação e da biblioteca da ECA, atenciosos, carinhosos e sempre dispostos a ajudar um pesquisador em apuros.

E finalmente ao professor e mestre Felisberto Sabino da Costa pela orientação desta pesquisa, pelo carinho e pela confiança ao me proporcionar a experiência mais enriquecedora e mais importante de minha vida: a docência. 
O amanhã jamais igualará o ontem; nada, exceto o mutável pode perdurar!

Frankenstein, Mary Shelley

Dou-lhe a certeza,

caro amigo e senhor. Vai regalar-se numa só hora mais que em todo um ano do seu viver monótono. Os cantares que se hão-de ouvir a espíritos mimosos, $e$ as imagens formosas, sedutoras, que esse coro gentil virá mostrando, será tudo real, que não prestígios de nenhuma arte oculta enganadora. Haverá para o olfato almas delícias. Depois para o paladar tão finos gostos como nunca os provou. Depois volúpias até às fibras íntimas. À obra!

Tudo é prestes.

Espíritos potentes!

Podeis principiar. Eis-nos presentes.

Fausto, Goethe 


\section{RESUMO}

A pesquisa analisa como a forma do monstro e o conceito da máscara atravessam o tempo histórico como elementos paradoxalmente de coerção social e política, como também exercem a função de objeto de transformação pessoal. Munidos destas duas abstrações, o videoperformer brasileiro Otávio Donasci e o encenador canadense Denis Marleau utilizam máscaras videográficas e, através de suas obras, revelam respectivamente as aspirações das sociedades de controle: prometeica e fáustica.

\section{Palavra-chave:}

Monstros - máscaras - máscaras videográficas - sociedade do controle - prometeico fáustico - teatro - Otávio Donasci - Denis Marleau. 


\section{RÉSUMÉ}

La recherche analyse comment la forme du monstre et le concept du masque traversent le temps historique comme des éléments, paradoxalement, de coercition sociale et politique, mais aussi exercent la fonction d'objet de transformation personnelle. Á partir de ces deux abstractions, le videoperformer brésilien, Otávio Donasci et le régisseur canadien Denis Marleau utilisent des masques vidéographiques et, à travers ses œuvres, révèlent respectivement les aspirations des sociétés de contrôle: prometheique et faustienne.

\section{Mots-clés:}

Monstres - masques - masques vidéographiques - sociétés de contrôle - prometheique - faustienne - Théâtre - Otávio Donasci - Denis Marleau. 


\section{LISTA DE ILUSTRAÇÕES}

Figura 1 - Blêmia - Hartmann Schedel, Chronica Mundi, Nuremberg, Anton Koberger - 1493 .

Figura 2 - Ciápode - Hartmann Schedel, Chronica Mundi, Nuremberg, Anton Koberger - 1493.

Figura 3 - Cinocéfalos - Mestre Boucicaut, Livre des Merveilles, século XV, Paris, Bibliothèque Nationale.

Figura 4 - Alexandre luta contra os homens selvagens e as bestas de Le Livre et la vraye historie du bom roi. Alexandre Royal, ms. 20, b XX, f. 51, séc XV, Londres, British Library.

Figura 5 - Ulisses Aldrovandi. Monstrorum historia - 1642.

Figura 6 - Conrad Gesner. Historia animalium - 1549.

Figura 7 - Ulisses Aldrovandi. Monstrorum historia - 1642.

Figura 8 - Ambroise Paré. Des monstres et prodiges. Paris : Nicolas Buon- 1628

Figura 9 - capa do livro Malleus Maleficarum -1487. Strasbourg. França.

Figura 10 - Códex Gigas. Biblioteca Nacional da Suécia - 1200 d.C. e 1230 d.C.

Figura 11 - Pã e Syrinx, quadro de Nicolas Poussin -1637, Dresden, Alemanha Gemäldegalerie Alte Meister.

Figura 12 - As Tentações de Santo Antão (1495-1510), Hieronymus Bosh. Museu Nacional de Arte Antiga, em Portugal, (reprodução parcial).

Figura 13 - Pasquel Penon, o homem de duas cabeças, nasceu no México em 1862. Trabalhou até que a cabeça de cima sofreu um ataque de paralisia, deixando-o mentalmente afetado. A partir de então, começou a atuar no Sell's Circus. Fotografia tirada 17 de agosto de 1917. Coleção Akimitsu Naruyama. 
Figura 14 - Mulher não identificada com um bebê gêmeo siamês crescendo para fora do seu abdômen; a cabeça cresce por dentro do seu corpo. A mulher chamase, provavelmente, Margaret Clark - 1947. Coleção Akimitsu Naruyama.

Figura 15 - ORLAN, The Reincarnation of Saint Orlan, (1990 - 1993). Depois das operações.

Figura 16 - Stelarc. Third Hand - 1981.

Figura 17 - Máscara de madeira Gelede Yoruba (1930-1960) - Indianapolis Museum of Art.

Figura 18 - Caligo memnon - Borboleta do gênero Caligo encontrada desde o México até a Floresta Amazônica.

Figura 19 - Cabeça de Medusa que adorna escudo de Forma circular, Obra de Filippo y Francesco Negroli - 1541.

Figura 20 - Artemis de Éfeso - Museu Capitolino, Roma.

Figura 21 - Máscara de Dionísio, Myrina, século II a.C.

Figura 22 - Jacques Copeau.

Figura 23 - Jacques Lecoq.

Figura 24 - Núcleo de Máscara - Escola Livre de Teatro. Mostra de processo, máscara neutra - 2009.

Figura 25 - Máscaras Larvárias - USP - 2013.

Figura 26 - Enrico Bonavera - Arlecchino, servidor de dois patrões. Piccolo Teatro di Milano “Arlecchino Tour - New York - 2005.

Figura 27 - The bride of Frankenstein. Filme de James Whale - 1935.

Figura 28 - Videotauro.

Figura 29 - Videobusto. SESC - Pompeia. SP - 1992.

Figura 30 - Videomanequim - IX VIDEOBRASIL.

Figura 31 - Videocriaturas Família.

Figura 32 - Videocriatura e Videofantoche. 
Figura 33 - Videotango no circuito bodearte - 2012

Figura 34 - PlasmaCriatura - videocriatura com rosto e parte do corpo de monitor de plasma de 42 polegadas.

Figuras 35, 36, 37 e 38 - Donasci - demonstrando a utilização da videocriatura.

Figura 39 - Fausto (Alemanha - 1926) Filme de F.W. Murnau.

Figura 40 - Denis Marleau.

Figura 41 - Le trois derniers jours de Fernando Pessoa - 1997.

Figura 42 - exemplo de moldes - Cabeças em gesso para exposição de manequins Jean Paul Gaultier, criadas originalmente para Musée des beaux-arts de Montréal - 2011.

Figuras 43, 44 e 45 - Dors mom petit enfant - 2004.

Figuras 46 e 47 - Les Aveugles - Fantasmagories Tecnhologiques - 2002.

Figuras 48, 49 e 50 - Une Fête pour Boris - 2009.

Figuras 51 e 52 - Agamennon - 2011.

Figura 53 - Gran Serata Futurista 1909 - 1930 - Fabio Mauri - 1980. 


\section{LISTA DE TABELAS}

Tabela 1 - Os quatro modos de ser - Pierre Levy.

Tabela 2 - As quatro passagens de ser - Pierre Levy. 


\section{Sumário}

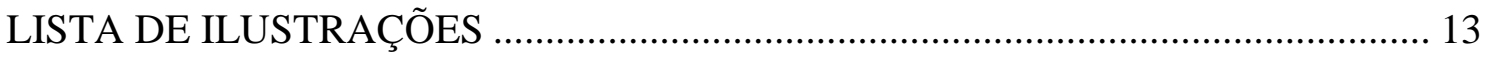

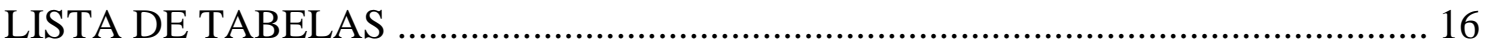

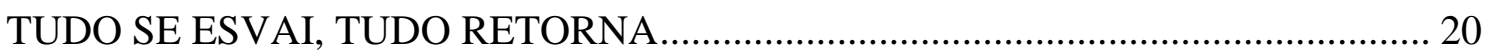

\section{CAPÍTULO 1 - MONSTROS: EXCEDER PARA CONTROLAR}

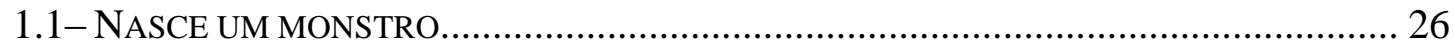

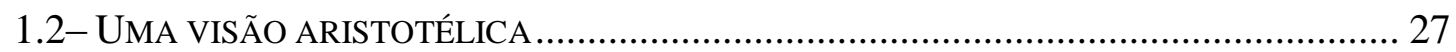

1.3 - PRODÍGIOS E RAÇAS FABULOSAS NO IMAGINÁRIO MEDIEVAL ............................... 29

1.4 - OS MONSTROS MARAVILHOSOS DE SANTO AGOSTINHO ...................................... 35

1.5 - OS BESTIÁRIOS DO RENASCIMENTO .................................................................... 38

1.6 - O MONSTRO CADA VEZ MAIS PERTO ................................................................... 42

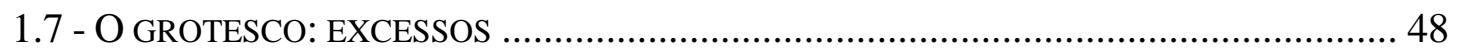

1.8 - A TERATOLOGIA COMO DIVERSÃO. OS FREAK-SHOWS ...................................... 50

1.9 - MONSTROS HÍBRIDOS: BODY-BUILDERS, CIBORGUES E MUTANTES ...................... 57

1.10 - UMA PEQUENA, MAS MONSTRUOSA CONCLUSÃO............................................. 62

\section{CAPÍTULO 2 - MÁSCARAS: ESCONDER PARA REVELAR}

2.1 - PALIMPSESTOS CORPORAIS. A MÁSCARA E SEUS CONCEITOS ...................................... 68

2.2 - As TRÊS POTÊNCIAS SAGRADAS DA MÁSCARA..................................................... 73

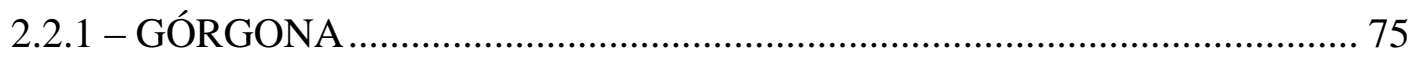

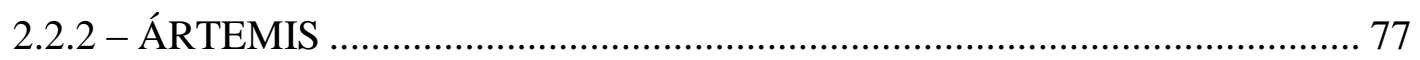

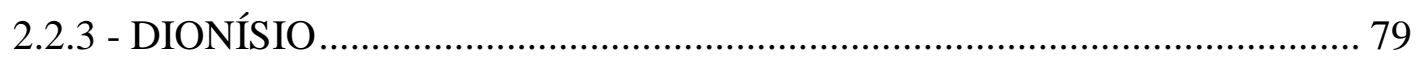

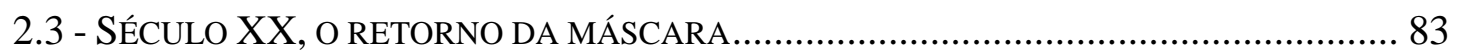

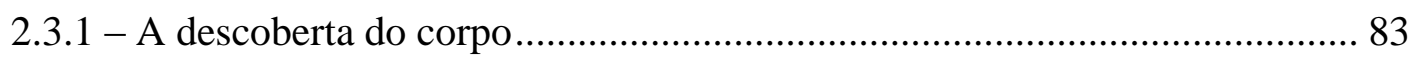

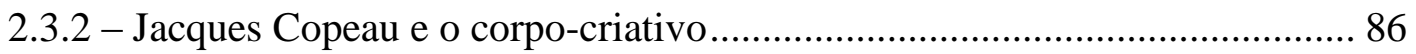

2.3.3 - O corpo-poético de Jacques Lecoq........................................................ 88

2.3.4 - Novas tecnologias: corpo-projetado/corpo híbrido ................................... 94

\section{CAPÍTULO 3 - MONSTRO-MÁSCARAS VIDEOGRÁFICAS: UNIR PARA REPRESENTAR}

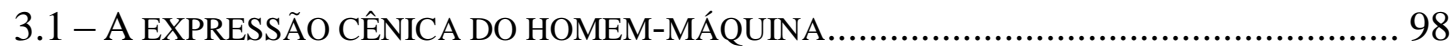

3.2 - SocIEDADES DA TÉCNICA - DE PROMETEU A FAUSTO. ........................................ 99

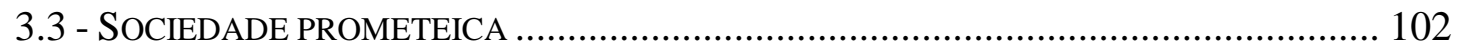

3.4 - OTÁVIO DONASCI - A TELA COMO SEGUNDA PELE.............................................. 104

3.4.1 - o mito de Frankenstein ....................................................................... 108

3.4.2 - A técnica por trás da técnica ................................................................ 111

3.4.3 - Videocriaturas prometeicas............................................................. 118 
3.5 - SOCIEDADE FÁUSTICA .

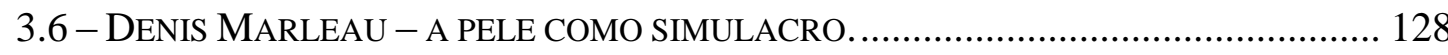

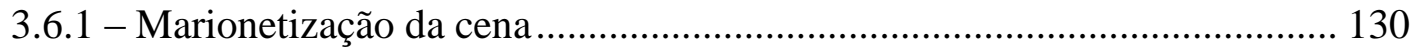

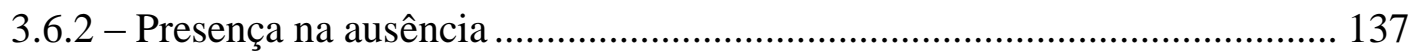

3.6.3 - Fantasmagorias fáusticas ............................................................... 140

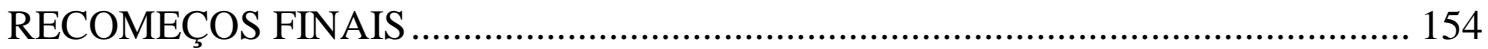

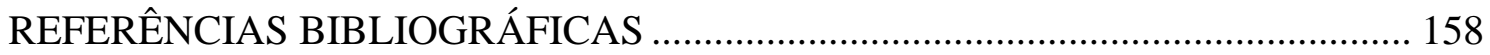

ANEXO 1 - DESCRIÇÕES SOBRE A MULHER DO MALLEUS MALLEFICARUM

170

ANEXO 2 - FREAKS - A DEFORMIDADE COMO DIVERSÃO. 


\section{Tudo se esvai, tudo retorna}

O propósito das linhas que se seguem é apresentar como a forma do monstro e o conceito de máscara se renovam com o passar do tempo e como as antefaces videográficas do videoperformer brasileiro Otávio Donasci, e do diretor canadense Denis Marleau, unem cenicamente o paradoxo contido na máscara do "esconder para revelar" com a forma do monstro, o "exceder para controlar", num ritual cênico cheio de estranheza e ao mesmo tempo identificação com o tempo e com o pensamento recorrente do período em que estão inseridos. Ambos celebram, identificam e expõem o pós-biológico, o homem híbrido, o homem da técnica celebrado pelas correntes de pensamento chamadas prometeicas e fáusticas: "unem para representar". Nesta mediação sujeito/objeto, máscara/monstro, presença/ausência, as máscaras videográficas criam um potencial poético através de um novo ser, de um duplo misturando realidade e fantasia. Processos estes inerentes à alteridade humana, onde a imagem técnica não constitui a perda de contato com o sensível e sim, cria um novo modelo de interlocução.

Inicialmente discute-se a fascinação do olhar pela qual o monstro nos arrebata com seu excesso de presença, dos prodígios da visão aristotélica, das raças fabulosas medievais, das mirabilias de Santo Agostinho, da invenção do diabo, do grotesco, dos freak-shows e a vertentes híbridas como os body-builders, ciborgues e mutantes.

A figura do monstro tão antiga quanto o homem, sempre assumiu um poder imagético preponderante como duplo, uma vez que foi transformando-se ao longo dos tempos conforme os interesses políticos, econômicos e sociais. Um produto cultural concebido em algum momento da história para assegurar, reforçar ou mesmo transformar ideias em verdades absolutas, garantindo desta forma determinado comportamento dentro de um sistema ideológico. Nesta figuração impera, como a máscara, a lei do eterno retorno. Nietzsche em seu livro Ciência Gaia (1882) descreve que a vida parece ser uma sucessão de alternâncias que se repetem eternamente. Criação e destruição, alegria e tristeza, saúde e doença, o bem e o mal, belo e feio. Tudo se esvai, tudo retorna. Não obstante, estas duas faces não se antagonizam, mas são concomitantes, um completando o outro num jogo perpétuo. 
Na sequência aborda-se como a máscara cênica ainda conserva em essência os conceitos da máscara ritual, sagrada, portentora dos segredos dos deuses. Artistas periodicamente se inspiram em posturas da Commedia Dell'arte ou das máscaras gregas trágicas ou cômicas, ou exploram a linguagem dos teatros tradicionais do Oriente, como o Nô, Katakhali e o teatro balinês, interessados também, pelas cerimônias do passado e pelos rituais.

[...]Graças aos artistas, pudemos entrar mais profundamente nas técnicas do jogo com máscaras, captar as implicações da máscara na concepção e no desenvolvimento do espetáculo, medir os perigos de uma teorização rígida num domínio em que tudo está sempre para reformular e para redescobrir. (ASLAN, 1999, pág. 280-281).

Símbolo entre os gregos que permeia duas realidades, a natureza e a sobrenatureza, a máscara possibilita a imagem figurada do deus, do demônio, de animais ou de figuras arquetípicas, gerando o produto de uma imitação (mimese) requintada pelo seu caráter técnico e ilusionista. Contudo, com o passar do tempo perde sua conotação religiosa e liga-se ao domínio estético da realidade, ao deixar de ser um instrumento mágico-religioso para se estabelecer como objeto artístico.

Apesar de tal mudança, a máscara conserva em seu âmago a representatividade da potência divina espelhada em três figuras: a Górgona, que é uma potência inteiramente máscara, que atua nela e através dela; Ártemis, uma deusa que nunca foi representada por uma máscara mas que reserva em seu culto um lugar aos disfarces; e Dionísio, que ocupa em todos os níveis afinidades tão íntima com ela que chega a ser considerado o deus-máscara.

Conforme AMARAL (1991), com o teatro erudito da Renascença que traz a figura do dramaturgo e a peça escrita, a máscara perde espaço e atua com finalidade cenográfica, "onde entra o pensamento racional, ela se torna simples adorno" (pág.49). Todavia no século XX um fator influencia o retorno da máscara aos palcos, devido à conscientização do corpo a partir do início do século com os saberes médicos e a espetacularização dos esportes. Paralelamente, a influência da arte abstrata africana, do teatro oriental revisitado por grandes nomes como Craig, Maeterlinck, Meyerhold, Copeau, Lecoq e nos experimentos cênicos da Bauhaus, a máscara adquire um novo 
estatuto, um objeto de treinamento corporal, exigindo do ator tempo, paciência e muita concentração. Portar uma máscara exige tal atenção e precisão de movimento em mínimos gestos, o que confere ao ator uma grande sensibilidade aos estímulos físicos que o cercam. O tempo dilata, o corpo transmuta em nuances extracotidianas, o que confere ao seu gestual um poder maior de comunicação sígnica e de imaginação.

Finalmente por intermédio da lei do eterno retorno, monstro e máscara reafirmam-se como objetos adaptáveis e correspondentes visualmente à época em que estão inseridos, agora no seu formato videográfico, numa adequação às novas tecnologias. O conjunto de técnicas e de habilidades artísticas do Renascimento até o século XIX eram artesanais, ou seja, dependiam de uma habilidade manual. Com a terceira fase da Revolução Industrial, a técnica de produzir imagens potencializa-se e o artista produz suas obras através da mediação de dispositivos maquínicos. Para SANTAELLA (2005), o poder revolucionário da máquina fotográfica resultou gradativamente na desconstrução da visualidade vigente até os dias atuais.

Desta forma, quando um novo meio de produção de linguagem e de comunicação surge: num primeiro momento, o novo meio provoca um impacto sobre as formas e meios antigos. Posteriormente, os meios e linguagens que podem nascer deste choque entre o novo e o antigo são tomados pelos artistas como objeto de experimentação.

A partir deste pressuposto a arte do vídeo, desde 1970, expande-se com o surgimento das videoinstalações e ambientações multimídia, instaurando novas paisagens sígnicas em ambientes que colocam em aposição objetos, imagens artesanais bi e tridimensionais, fotos, filmes, vídeos em arquiteturas muitas vezes inusitadas que proporcionam novas ordens de sensibilidade. Como também, a partir de 1990, a arte computacional ganha força com o alvorecer da era digital. A mediação feita por computador produz uma hibridização sem precedentes ampliando a percepção humana através da virtualização, o que por sua vez alimenta o imaginário de uma reconstrução "pós-biológica".

Sendo assim, o corpo midiático, através de seu simulacro (imagem) fomenta experimentações através da substituição do real, acarretando um processo gerado pelo seu duplo operatório. BAUDRILLARD (1981) é enfático ao estabelecer que dissimular 
é fingir não ter o que se tem (presença). Já simular é fingir ter o que não se tem (ausência). "Precisamos de um passado visível, um continum visível, um mito visível da origem, que nos tranquilize sobre os nossos fins" (pág.18). Trata-se de provar o real pelo imaginário, o teatro pelo antiteatro, a arte pela antiarte, tudo se metamorfoseia no seu termo inverso, no seu duplo.

As monstro-máscaras videográficas com características grotescas, simbolistas e neoexpressionistas, trazem à tona a nova relação do homem com o mundo. A imagem torna-se poderosa e para LEHMANN (2007), a percepção imediata é intersubjetivada e coloca em jogo a interação corporal, "uma relação de encontro comum em uma situação social, que constitui outro tempo entre sujeitos" (pág.366). A partir deste pressuposto, o videoperformer brasileiro Otávio Donasci e o diretor canadense Denis Marleau, cada um ao seu modo, concebem suas monstro-máscaras de diferentes pontos de vista. Donasci em sua videocriatura potencializa a forma presencial do ator, duplicando-o: corpo (ator presencial) + imagem (rosto reproduzido videograficamente de outro ator). Marleau, por sua vez, multiplica a imagem de um único ator, sobreposta em vários bonecos, em cabeças cenográficas, criando vários rostos videográficos que promovem a presença na ausência.

Instintivamente ao unirem o monstro (sombra) e máscara (persona), os dois artistas criam suas obras expondo os ideais da sociedade do controle e da técnica, corroborando os anseios prometeicos (Donasci) e fáusticos (Marleau) presentes atualmente no pensamento do sociólogo português Hermínio Martins. O mito do titã Prometeu interessa-se, ou pelo menos em seu pensamento original, no benefício que a ciência e a tecnologia promovem ao ser humano, no que o saber pode melhorar a sociedade. Em outra vertente, a lenda de Fausto, da ambição de conhecimento sem limites torna-se patente. Sua intenção é abolir as doenças, as deformidades e até mesmo transferir o cérebro humano para dentro de uma máquina. Para tal corrente o homem deve controlar seu próprio destino sem a interferência do divino através da bioinformática e biotecnologia.

Donasci/Marleau expõem, profetizam e materializam o pensamento ideológico pelo qual o homem contemporâneo sonha atingir. Ambos projetam um espaço cênico, onde as figuras aparentam ser mais marionetes do que personagens em si, apresentam-se 
como imagens especulares de sonhos e de temores, hibridismos pós-biológicos, espelho da realidade de uma sociedade cada vez mais virtual. 


\section{O MONSTRO}

Monstro (latim monstrum). 1. Produção animal ou vegetal contrária a ordem regular da natureza. 2. Ser monstruoso das lendas. 3. Animal de tamanho extraordinário. 4. [Figurado] pessoa muito feia. 5. Pessoa perversa, desnaturada. 6. Prodígio, portento, assombro (a boa parte). 7. Monstruoso, colossal. 8. Muito grande em quantidade.

Dicionário Michaelis

\section{CAPÍtULO 1}

\section{EXCEDER PARA CONTROLAR}




\section{1- Nasce um monstro}

A figura monstruosa acompanha a humanidade desde os seus primórdios como seu artífice catártico. A priori o monstro é etimologicamente associado a palavra monstrare que significa mostrar, designar, indicar com o olhar. Como também pode absorver o sentido de moneo, advertir. Sentido este muito usado por Aristóteles e Santo Agostinho, que interpretam o monstro como um conselho, uma advertência dada pelos deuses.

Os seres ou eventos monstruosos, no sentido religioso, carregam em si contrariedades, quando se trata de sinais de descontentamento dos deuses com a comunidade de adoradores através do nascimento de uma criança ou animal anatomicamente peculiar. Assim, de um contexto em que os monstra deveriam atemorizar não tanto pelo que aparentam, mas pelo que carregam em si enquanto misteriosos desdobramentos no âmbito da quebra da PaxDeorum ${ }^{1}$. TREVIZAM (2008) enfatiza que a língua latina estendeu-lhe a vigência ameaçadora também para casos em que sua face temível era apenas mantida em superfície, seja através de um mau evento realizado no mundo concreto, seja de um ser real ou imaginário passível de causar arrepios. Do prodígio que adverte da vontade divina, o significado do monstro sofre constantes mutações e também pode ser caracterizado como um ente de características inusitadas. Os múltiplos sentidos da monstruosidade são características da polissemia do vocábulo latino monstrum que revela uma rica série de caminhos semânticos, expressando desta forma um objeto ou ser de caráter sobrenatural.

Não só no mundo da fantasia ou da imaginação habitava o monstro: as instituições romanas já previam a efetiva existência e regras do monstruoso com o intuito de atribuir-lhe um espaço aceitável no plano das relações intra-humanas. Seres que não podiam ser reconhecidos como filhos de seus pais por destoarem do aceitável quanto aos mínimos padrões da "normalidade” humana. “[...] as Doze Tábuas das Leis aludiam ao destino esperado para tais monstra humanos (a execução sumária) [...]" (TREVIZAM, 2008. pág. 76).

\footnotetext{
${ }^{1}$ Os romanos praticavam rituais pagãos, acreditando que eram importantes para alcançar um estado de PaxDeorum (A Paz dos deuses) em vez de Deorum Ira (A Ira dos deuses). As definições de monstro se desenvolvem de maneira quase histórica: para os antigos gregos e romanos, o monstro era um prodígio, um aviso contra a infração da PaxDeorum. Qualquer aliança que os deuses pudessem ter tido com os humanos estava para ser reincidida por causa de algum malefício.
} 
Então as pessoas nascidas com anomalias físicas com o número de dedos a mais nas mãos ou pés, cabeça disforme ou genitais ambíguos por exemplo, ao longo do tempo foram associadas ao bizarro, ao risível, ao medo, à pena, além das implicações religiosas que julgavam a deformidade como castigo divino. $\mathrm{O}$ monstro existe não para mostrar o que somos, mas o que poderíamos ser, para experimentarmos os limites de nossa humanidade. Entre monstros criados pelo imaginário e a deformidade física real forçamos nossa difusa existência em seres cada vez mais numerosos e variados com o intuito de reforçar ou encobrir as mudanças, como se uma nova forma exigisse um período de transição. "[...] Porque nos períodos transitórios, de intensa mudança cultural, [...] surgem as mais variadas aberrações”. (GIL, 2006, pág.16). Cada período terá seu respectivo monstro, seu espelho, seu duplo camuflado em agente opressor ou catártico que impelirá a humanidade a criar uma imagem distorcida de si mesma.

\section{2- Uma visão aristotélica}

Para Aristóteles o monstro é um fenômeno que se opõe à "generalidade dos casos", mas não à natureza concebida como totalidade. Em seu livro sobre a Geração dos Animais esboça até com certo rigor científico uma reflexão sobre os seres vivos. A formação dos indivíduos, seja animal ou humano, insere-se num embate entre a Forma (masculino - ser em ato) e a Matéria (feminino - ser em potência). A primeira etapa deste encontro entre Forma e Matéria decidirá a natureza do embrião e, em primeiro lugar, seu sexo. Caso a Forma consiga domesticar a Matéria, o embrião será do sexo masculino e, o inverso, do sexo feminino. O ideal nesta concepção aristotélica é a reprodução idêntica: um menino parecido com o pai (Forma). Quanto maior a distância deste modelo, maior será a imperfeição e nesta diferença, por via de regra, reside o monstro, destoante dos seres que o geraram.

A noção de monstruosidade refere-se a qualquer criança que não se pareça com os pais e, a partir deste pressuposto, seria caracterizada como monstro devido à natureza ter saído dos limites do tipo original. Contudo Aristóteles toma cuidado, segundo KAPPLER (2008), em ressaltar que tal imperfeição é necessária à sobrevivência da espécie; portanto não seria ilícito deduzir que a mulher não é um monstro, mas simplesmente um homem imperfeito. Embora o nascimento de indivíduos femininos 
não seja absolutamente uma monstruosidade, por ser necessária e generalizada, na maioria dos casos onde o triunfo é da Matéria, o princípio feminino, a porta estaria aberta para a monstruosidade.

Os atos envolvidos em mudanças chamam-se "formas", e o termo "matéria" é utilizado como um termo técnico para designar aquilo que possui a capacidade para sofrer uma mudança substancial. Desta maneira, Aristóteles sustenta também a ideia da mulher ser um homem castrado. Para DA SILVA; FOLBERG (2008) o monismo sexual, ou seja, a hipótese de um só, e mesmo aparelho genital é a primeira das teorias sexuais freudianas e tem em sua concepção a importância da particularidade e do determinismo para a feminilidade, uma vez que o único órgão sexual reconhecido pela criança nos dois sexos é o órgão masculino. Tal distinção anatômica se expressa em consequências psíquicas, constatando-se que as meninas responsabilizam a mãe pela falta do pênis e "não perdoam por terem sido, desse modo, colocadas em desvantagem". (FREUD, 1932. pág. 73).

As deformidades dos fetos serão associadas à imagem do monstro de Aristóteles até o século XVIII. Nesta corrente de pensamento, existe uma relação muito direta entre os nascimentos monstruosos e a depravação do desejo feminino, que poderia ser resumida da seguinte maneira: a devassidão é uma das causas da existência dos monstros, acrescentando uma carga metafórica, uma mácula moral, "à sujidade matricial que alimenta o embrião". (GIL, 2006, pág. 85). A metáfora transforma-se em signo: o filho carrega consigo a anomalia física, visível ao olhar de todos da alma da mãe. Corrupção do embrião de origem visceral apodrecida.

"O olhar é capaz de arrebatar a imagem do outro e de absorver o desejo no corpo, de tal modo que irá moldar a matéria do embrião. De maneira menos direta, os desejos, essas marcas que os recém-nascidos trazem no corpo, resultam de desejos animalescos, incestuosos, canibais." (GIL, 2006. pag. 89). Esta tradição de atribuir monstros ao desregramento, aos apetites da carne e, sobretudo, aos desejos insatisfeitos irá se expandir. O monstro seja qual for a carga simbólica, aparece visível como a natureza culpada da mãe. Aqui temos a tentativa de tornar o desejo socialmente controlado. Ou seja, ser aceito na comunidade, ser Homem (e não monstro) é aquele que sabe cumprir as regras sociais, pessoais ou coletivas. Desta forma, adaptar-se as regras é deixar de se animalizar, é entrar em contato com o duplo para manter a projeção pré- 
concebida daquela sociedade em que se habita, visto que o monstro assinala o limite interno da humanidade.

\section{3 - Prodígios e raças fabulosas no imaginário medieval}

Nas fronteiras do mundo europeu-ocidental pairavam regiões recheadas de mistérios, de puro caos, onde histórias fabulosas de raças fantásticas, de seres que habitavam as orlas (zonas periféricas) eram relatadas por vários navegantes. De pigmeus, aves com pescoço longo como as girafas, os ciápodes, munidos de um único pé que lhes serviam de guarda-sol com o qual se protegiam das intempéries; cinocéfalos, homens com cabeças de cachorro, que se comunicavam através de latidos; homens peludos e sem cabeça, com olhos nos ombros, conhecidos como blêmias, entre outros e que povoavam as mitologias, nutriam as superstições, agitavam os espíritos e aguçavam o imaginário social.

No Ocidente medieval acredita-se que existam, nos confins da Terra, seres que não se sabem ao certo se eram humanos ou mais próximos do animalesco: as raças fabulosas do Oriente. Esta estereotipia imagética não irá mudar, com relatos dos viajantes gregos que foram transmitidos através de compiladores e historiadores, entre os quais os mais ilustres estão: Homero, Heródoto, Plínio, Estrabão, Solinus e Diodoro da Sicília ${ }^{2}$.

Uma espécie de apocalipse, sob o signo da besta, do medo e do mistério produz na imaginação das pessoas uma série de ornamentos abstratos e um considerável universo monstruoso. Para DEL PRIORE (2000) nesse período o Oriente transmite ao Ocidente um bestiário fantástico, que assimila e integra sistemas culturais. A arte, com sua decoração exuberante, seus monstros, sua fauna, sua humanidade, parece pertencer menos à natureza que algum reino inventado e às regiões da imaginação sem limites.

\footnotetext{
${ }^{2}$ Tais autores se basearam em duas fontes: o tratado de Ctésias (400 a.C.) sobre a Índia e a obra de Megástenes (cerca de 290 a.C.), geógrafo grego que acompanhou Alexandre ao Oriente (GIL, 2006. P. 23-24).
} 
A relação da teratologia ${ }^{3}$ na Idade Média diz respeito aos nascimentos monstruosos, considerados como presságios, portenta; ao mesmo tempo em que se limita a admitir a existência de raças fabulosas nos confins da Terra. Os portentos eram eventos prodigiosos e estupefacientes, mas naturais (como o nascimento de bebês hermafroditas ou dicéfalos). O mundo clássico era sensível aos portentos, que eram constantemente associados como signos de desgraça iminente. Eram acontecimentos como chuvas de sangue, incidentes inquietantes, chamas no céu, nascimentos anômalos ou crianças de duplo sexo.

É muito provável que tenha sido com base no conhecimento de anomalias semelhantes que Platão pode imaginar a figura do andrógino originário e que sobre as mesmas bases tenham sido concebidos, pelo menos em parte, muito dos monstros tidos como habitantes da África ou Ásia, dos quais só havia raras e imprecisas notícias. (ECO, 2007. pág.107).

Como sinônimo de portento e prodígio, a palavra monstro tem um significado que projeta seu sentido no futuro. Mas o destino é, quase sempre, inexorável. Escaparlhe é uma impossibilidade. Isidoro ${ }^{4}$ exemplifica a ação premonitória de um portento com o relato de um nascimento que anuncia a morte de Alexandre, o Grande. Uma criança nasceu como criatura híbrida, tendo a parte superior de seu corpo a forma humana, com os membros mortos, e a parte inferior a forma de um animal (besta), mas com os membros vivos, significando que o pior deveria sobreviver ao melhor. Do mesmo modo, previu-se a destruição do Império de Xerxes quando uma mula nasceu de uma égua. Nesse sentido, Isidoro os aproxima dos sonhos e dos oráculos. Os premonitórios, porém, correspondem a alguns tipos de portentos.

\footnotetext{
${ }^{3}$ Teratologia é parte da História Natural ou da Medicina que trata dos monstros, das formas excepcionais dos seres. Estudo das malformações.

${ }^{4}$ Santo Isidoro (c.560-636), nascido em Sevilha na época visigoda. É um dos grandes elos de transmissão da cultura clássica para a Idade Média. Sua obra Etimologias é uma espécie de enciclopédia, muitíssimo utilizada ao longo de toda a Idade Média e conta com um capítulo que disserta sobre os homens e os seres prodigiosos.
} 
Os monstros que se apresentam como sinais do que ocorrerá no futuro morrem pouco depois de nascer. Mas sua existência não é contrária à natureza. Tais criaturas nascem da vontade divina, e a natureza (natura) de todo ser criado é parte da vontade divina. Assim, se os portentos nascem de acordo com a vontade de Deus, não podem ser entendidos como contranatural.

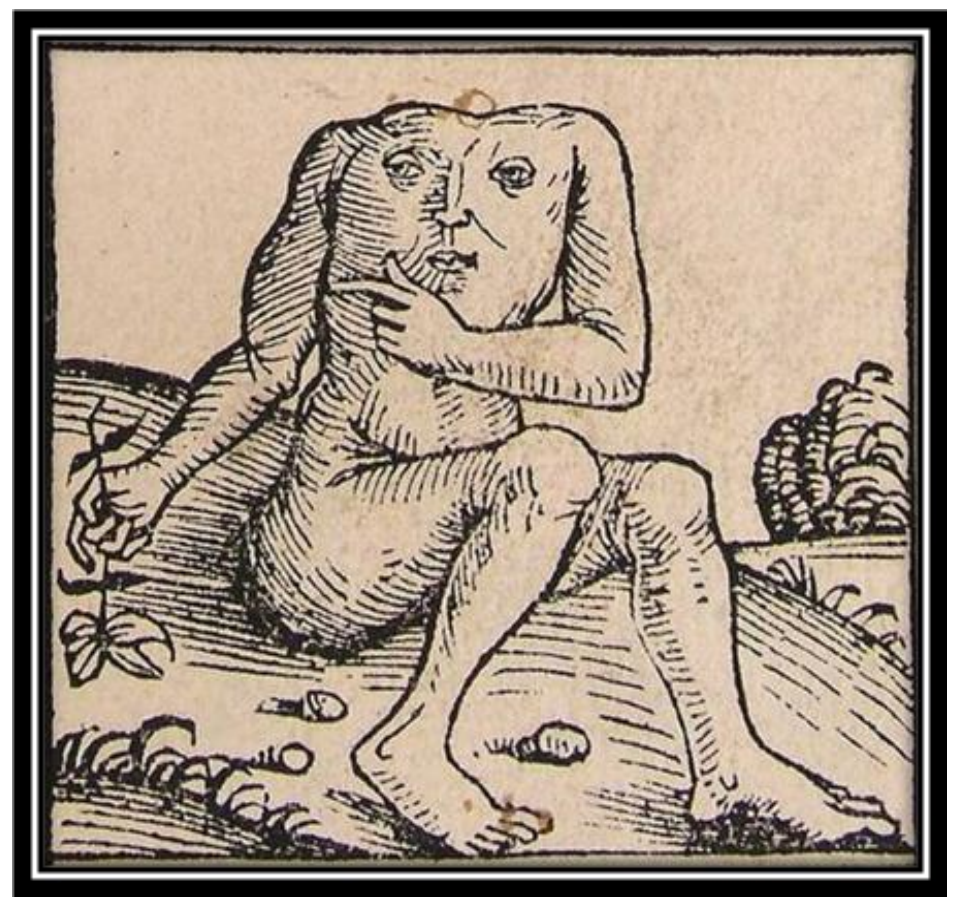

Figura 1 - .Blêmia - Hartmann Schedel, Chronica Mundi, Nuremberg, Anton Koberger - 1493. 


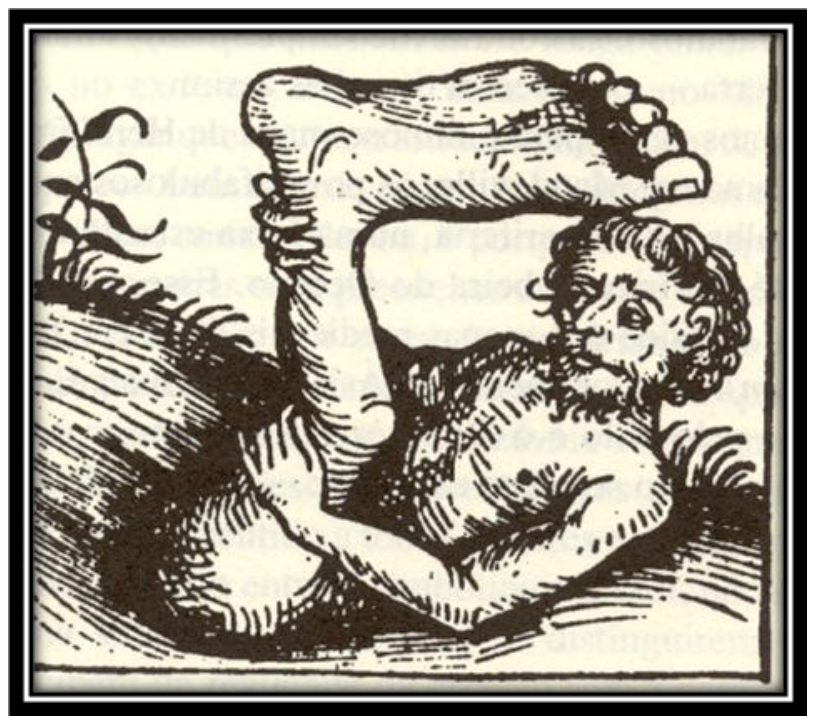

Figura 2 - Ciápode - Hartmann Schedel, Chronica Mundi, Nuremberg, Anton Koberger - 1493

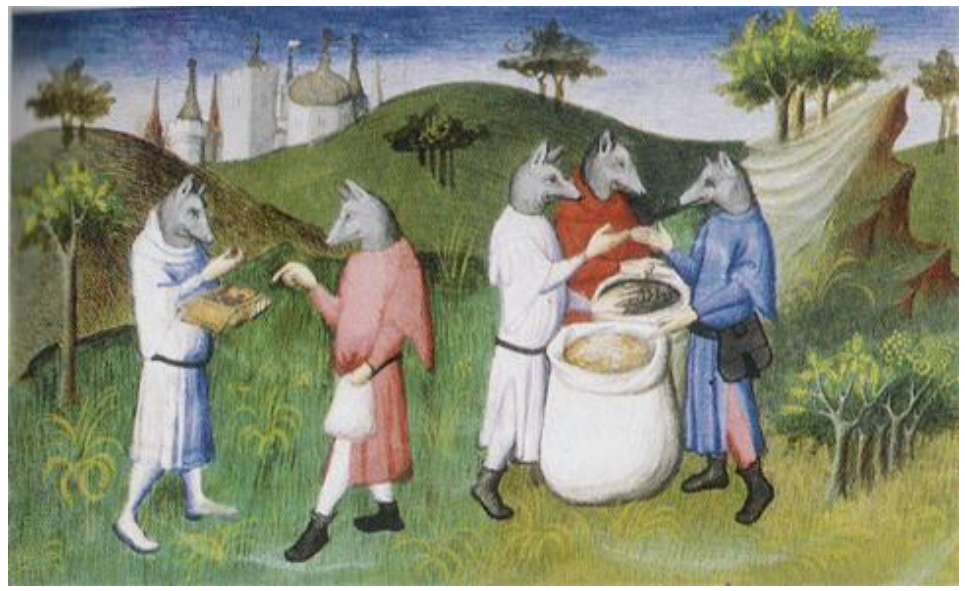

Figura 3 - Cinocéfalos - Mestre Boucicaut, Livre des Merveilles, século XV, Paris, Bibliothèque Nationale.

O Extremo Oriente torna-se uma terra de lendas devido a publicação do $O$ Romance de Alexandre, um conjunto de cartas supostamente escritas por Alexandre, o Grande, à sua mãe Olímpia e a seu preceptor, Aristóteles. Traduzidas para o latim tornaram-se leitura obrigatória, "as campanhas e as conquistas do grande rei serviam como pretexto para tratar de mil prodígios e maravilhas ocorridos na longínqua Índia, [...] as fantásticas aventuras de Alexandre eram vistas como páginas fiéis da história" (DEL PRIORE, 2000. pág.30). O relato abrangia de histórias de batalhas do rei contra 
comedores de carne humana a dragões, porcos voadores, de homens e mulheres com seis braços, gigantes e blêmias, entre outros seres fantásticos. Bem mais variados e interessantes do que as histórias eruditas, esses textos provocam a fascinação do público e cada autor procura, assim, tirar partido do sucesso da história anterior acrescentando novos personagens ou novos monstros a história. Sem procurar saber a verdade de tais fatos os homens acreditavam cegamente na existência das raças monstruosas e caso as evidências cotidianas não corroborassem a existência de tais seres fantásticos, testemunhos eram inventados que os descreviam com uma razoável dose de realidade.

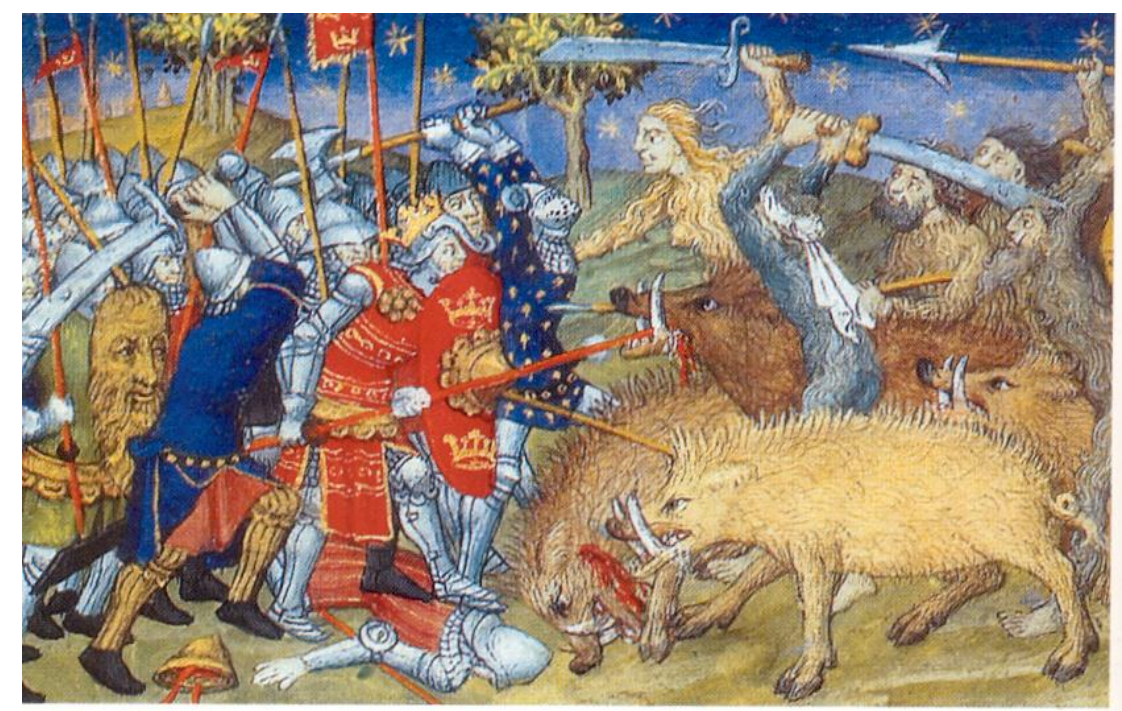

Figura 4 - Alexandre luta contra os homens selvagens e as bestas de Le Livre et la vraye historie du bon roi. Alexandre Royal, ms. 20, b XX, f. 51, séc XV, Londres, British Library.

Esta forma de criar monstros imaginários e condicioná-los aos extremos do mundo era uma forma de os escritores da época, segundo SCHNEIDER (1999) de tornar o indizível visível. Quando falamos do mal tendemos a criar referências metafóricas, relacionando um ser ou um acontecimento a algo que existe em um plano diferente. Quando o mal é transposto para a esfera legal, atribuímos-lhe o caráter de transgressão das leis sociais; quando o mal aparece no domínio religioso, o reconhecemos como uma quebra das leis divinas, e quando ele ocorre no reino estético ou moral, damos-lhe o nome de monstro ou monstruosidade. JEHA (2007) afirma que as metáforas mais comuns quando pensamos ou nos referimos simbolicamente ao mal, 
pensamos no crime, no pecado e na monstruosidade. Pelo fato de as metáforas alterarem a significação natural de uma palavra é substituí-la por outra, elas podem desmembrar a organização da realidade e recriá-las nas formas mais antinaturais possíveis.

Fomentar o medo sempre foi uma estratégia eficaz para perpetuar o poder vigente, através dos "medos particulares", ou seja, "medos nomeados" podem-se tornar operatório no nível coletivo com a distinção que a psiquiatria estabelece no plano individual entre medo e angústia. $\mathrm{O}$ temor, o espanto, o pavor, o terror dizem mais respeito ao medo; a inquietação, a ansiedade, a melancolia, à angústia.

O primeiro (medo) refere-se ao conhecido; a segunda (angústia), ao desconhecido. O medo é material, tem um objeto determinado que podemos determinar e enfrentar. A angústia é vivida como uma espera dolorosa diante de um perigo tão temível, mas claramente menos identificado: um sentimento global de insegurança. Desse modo, a ansiedade é mais difícil de suportar que o medo. Uma sensação de aperto na garganta, enfraquecimento das pernas, de tremor, acrescentada à apreensão com o futuro.

Para conservar o equilíbrio interno o Homem transforma e fragmenta a angústia incerta, infinita e indefinível em medos precisos de alguma coisa ou de alguém. $\mathrm{O}$ espírito humano fabrica permanentemente o medo para evitar uma angústia mórbida que resultaria da abolição do eu. Em uma sequência longa de traumatismo coletivo, desta forma vence-se a angústia "nomeando", isto é, identificando ou até mesmo "fabricando" medos "particulares".

O monstro é um excesso, uma forma de controle de multidões que determinam as opiniões e as crenças de uma multidão. Os fatores remotos trabalham com conceitos que impulsionam as multidões a adotarem certas convicções e serem incapazes de se afetarem por outras. Neste terreno germinam ideias novas com força e resultados que surpreendem, mas que só aparentemente são espontâneas, as ideias ficam nas camadas superficiais e tem adesão fulminantemente repentina. Por sua vez, os fatores imediatos são aqueles que, sobrepostos a um longo trabalho de persuasão, sem o qual não poderiam agir, provocam uma atitude ativa das multidões, isto é, fazem com que a ideia tome forma e desencadeiam-na com todas as consequências. Para LE BON (1980. pág.40), "é sob o impulso destes fatores imediatos que surgem as resoluções que abalam bruscamente as coletividades; é através deles que se declara um motim ou se 
decide uma greve; é ainda por meio deles que enormes maiorias levam um homem ao poder ou derrubam um governo". Todos os seres em multidão têm uma instintiva necessidade de obedecer a um condutor e uma opinião popular torna-se rapidamente uma opinião geral.

Os monstros desempenham, reconhecidamente, um papel político como sustentação do poder que rege as regras de uma sociedade. Grupos sociais precisam de fronteiras para manter seus membros unidos dentro delas e proteger-se contra os inimigos reais ou imaginários fora delas. As fronteiras existem para manter a ordem e qualquer transgressão desses limites causa desconforto, o que requer um retorno ao mundo que a sociedade acreditar ser o certo. O monstro é um estratagema, uma fórmula que rotula tudo que infringe os ideais vigentes, que desobedece aos limites culturais e portanto, deve ser combatido.

Os limites sociais afetam nosso conhecimento do mundo toda vez que ampliamos ou conquistamos novos territórios, o que por conseguinte afetam as fronteiras que controlam nossas vidas, fazendo com que elas também se movam. Da mesma forma, quando inventamos ou produzimos algo nossa visão de mundo tem de se adequar à nova ordem e, neste caso, acomodar outros seres ou novos fenômenos. JEHA (2007) completa: “nossa experiência se baseia em fundamentos epistemológicos e ontológicos; mudanças epistemológicas vão gerar alterações ontológicas, e um acréscimo ontológico vai forçar nosso conhecimento a se expandir". Quando isso ocorre, sentimos que nossas expectativas de ordem, que as fronteiras estabelecidas pela ciência, filosofia, moral e estética, foram transgredidas. E conceitualmente transgressões geram monstros.

\section{4 - Os monstros maravilhosos de Santo Agostinho}

Ao oferecer grande diversidade à monstruosidade, os povos exóticos invadiram a literatura erudita com as narrativas de viagem ou com as epopeias. Nestas narrativas, Santo Agostinho percebe a importância dos monstros no imaginário da população e perguntava-se: seriam os monstros ao mesmo tempo homens e criaturas de Deus? 
Porque os monstros tinham algo a mostrar (monstra=monstrare), manifestavam $($ ostenta $=$ ostentare $)$, prediziam (portenta $=$ pra-ostendere $)$ anunciavam (prodigia $=$ prodicere) e antecipavam tudo que Deus ameaçava realizar, futuramente, com os corpos humanos. Assim, os monstros são a imagem do que poderia acontecer aos homens se não seguissem um comportamento dentro das intenções pré-determinadas pela Igreja, além de instigá-los a pensar como seriam se não fossem como eram. Essa derivação é aceita por Santo Agostinho na medida em que ele via nos monstros mais do que a expressão da vontade de Deus.

As questões medievais sobre a existência da monstruosidade tinham como objetivo apontar se tais povos nos confins da terra realmente existiam. Se Deus nos criara sua imagem semelhança, as raças monstruosas lançavam uma confusão nessa identificação, porque seu excesso não os identifica com o sagrado. GIL (2006) salienta que a ambiguidade destas discussões deve-se pela solução que Santo Agostinho dera ao tema. Em seu texto Cidade de Deus apresenta o monstro como existente em todos os níveis da criação (evidente também para Aristóteles). Seja no reino humano, no animal, mineral ou no vegetal, seu interesse pelos monstros humanos ou considerados como tal representa um problema teológico. Sua preocupação era manter a unidade da espécie humana através de sua discussão sobre a veracidade ou não das raças monstruosas.

Entretanto, paradoxalmente, o significado dos nascimentos monstruosos como presságio é negado por Santo Agostinho pela recusa em acreditar na existência de povos fabulosos. O fato de não compreender o monstro não quer dizer que não tinha sido desejado por Deus. Não é uma advertência divina sua existência, porque não há como Deus ter falhado em sua obra. Apenas seres como nós, terrenos, ficamos chocados com tal monstruosidade, uma vez que não enxergamos o todo da criação. Com este pensamento os monstros para Santo Agostinho serão tratados como mirabilia, curiosidades maravilhosas da Natureza. Ao se retirar o estatuto de realidade contida nas raças de monstros, frequente na tradição clássica, e ao fazer da sua existência algo de provável e de incompreensível, ele torna-se maravilhoso. Santo Agostinho, ao mesmo tempo em que os integra no sistema de representações que a Bíblia contempla, abre a porta à admiração diante dessas mirabilias, situando os monstros no espaço terrestre.

Para KAPPLER (1994) Agostinho convida energicamente o fiel a não duvidar do bom fundamento e da perfeição da criação em sua totalidade: porque aquele que 
julgar estar diante de um erro do Criador, demonstra ter um espírito pobre, pois apenas enxerga um aspecto limitado do Todo e não pode perceber aquilo que o choca. $\mathrm{O}$ homem que duvida é simplesmente ignorante; seu horizonte é extremamente limitado. É o reencontro com a ideia aristotélica de que nada acontece por acaso e que Deus - ou a natureza - não podem se enganar.

Nas fronteiras da estranheza ao tratar de seres de formas bizarras a identidade humana, Santo Agostinho tenta minimizar ao máximo a bestialização do monstro. Ao dar-lhes um estatuto vizinho de mirabilia, abre a porta à integração das raças monstruosas no conceito cristão do mundo. Vale lembrar que, para ele, a diferença entre o monstro e o homem está no corpo considerado normal, cristão, ocidental e em seu pensamento torna-se necessário reduzir a aberração corporal que coloca em risco a alma humana. Este modo de pensar a natureza tem grande sucesso durante a Idade Média e está dividido em aspecto da ordem (sagrada ou profana) e do maravilhoso, do desconhecido. Este último está à beira da desordem, proporcionando um desafio constante e ameaça em relação ao primeiro. Para além da esfera da ordem estável marcada por sinais religiosos, sobeja o espaço mágico das figuras fantásticas.

Para inserir o monstro dentro da criação divina, Santo Agostinho criou a estrutura teológica da assimilação da cultura profana - popular e erudita - pela religião cristã. Sua intenção clara era de inserir os seres maravilhosos dentro da exegese dos textos sagrados. Contudo, o intento seria particularmente difícil, pois a cultura medieval deu origem a vários bestiários ${ }^{5}$ e romances maravilhosos que misturaram o profano e o sagrado, não no mesmo sentido que ele os entendia. GIL (2006) declara que já não se tratava apenas de ficar maravilhado com as lendas e romances, mas também de associar a lenda, as criaturas (reais ou legendárias) a um ensinamento moral.

O saber sobre os monstros foi herdado da Antiguidade (grega ou romana) e depois, a partir dos séculos XII e XIII, tomado de empréstimo ao Oriente, principalmente da China, onde a propensão intelectual em relação à monstruosidade não se renova. Até o século XV existem poucas criações ou pensamentos originais sobre

\footnotetext{
${ }^{5} \mathrm{O}$ primeiro texto a entrar no mundo cristão com esse caráter foi Fisiólogo, escrito em grego entre os séculos II e III e traduzido em seguida para o latim, além de várias línguas orientais, listando cerca de quarenta animais, pedras e árvores. Depois da descrição de cada ser, o Fisiólogo mostra como e por que cada um deles possuem um ensinamento ético e teológico. O leão, por exemplo, que segundo as lendas apaga as próprias pegadas com a cauda para escapar dos caçadores, transforma-se em símbolo de Cristo, que apaga os pecados dos homens. (ECO, 2007, pág.114).
} 
esse assunto; ainda que, no desenho e na pintura, encontre-se uma nova geração de monstros, será preciso esperar até o século XVI para se obter uma tentativa de reflexão coerente e sistemática sobre o assunto.

\section{5 - Os bestiários do Renascimento}

Ao longo da Idade Média os Bestiários ou Livro das Bestas foram obras singulares que marcaram este período por descreverem vários animais existentes ou seres imaginários através da sistematização deste conteúdo de forma empírica, simbólica e de caráter alegórico. Organiza-se em torno de pequenas narrativas com propósitos morais e didáticos, onde cada uma dessas narrativas é composta por duas partes distintas: uma parte descritiva de sentido literal (a descrição, proprietas ou naturas) e a sua moralização e interpretação teológica de sentido simbólico-alegórico (também designada como moralização, moralitas ou figuras). Para os autores de tais obras nada parece arbitrário na construção deste universo onírico, porque se apoia nas aparências, sem preocupação lógica ou científica à margem da biologia: humanidades, faunas e floras fundamentadas.

Os Bestiários são obras didáticas, controladas pela Igreja, que pretendem um entendimento monológico do monstruoso, entretanto a articulação do texto com as imagens permite uma infinidade de leituras diferentes. Suas ilustrações veiculam informações desiguais do texto escrito que favorecem a imaginação, criam uma relação dialógica que frequentemente questiona também a ideologia dominante. Esta ambivalência fornece imagens (símbolos) que não expressam uniformidade, podendo ser lidas de forma dúbia dentro do contexto em que surgem.

Os monstros são frutos de observações sem bases científicas de um universo constituído de uma geometria simbólica, segundo a escala de valores que insere elementos espirituais ou materiais, criando signos potentes de controle. Para (KAPPLER, 1994, pág. 14), "o universo medieval é extremamente estruturalista: a forma é o significante e é dela que se parte para imaginar o conteúdo ignorado ou para justificar o conteúdo conhecido". Não só no texto a vertente alegórica e simbólica do Bestiário se situa, mas através das imagens. Era uma forma de expressão de seu 
conteúdo aos que não sabiam ler, proporcionando um poder às imagens como fonte de "ensinamento" dos processos de união e totalidade de Deus. A imagem é lida em vários níveis, num processo de assimilação do conteúdo de forma gradual em que o sentido literal, através da observação, cede lugar aos significados alegórico, moral e anagógico ${ }^{6}$.

Os nascimentos monstruosos híbridos foram um sucesso levado aos limites mais extremos. Texto e imagem destas obras potencializam o hibridismo homem-animal, monstros semi-humanos e semianimais nascidos pelo cruzamento entre ambos. Podemos enxergar tal hibridismo como uma mestiçagem e formação de novos polos culturais, assim, as culturas dominantes continuam dominantes porque pertencem aos centros que disputam o controle e as dominadas continuam dominadas porque pertencem a polos periféricos que devem se acomodar a essa expressão.

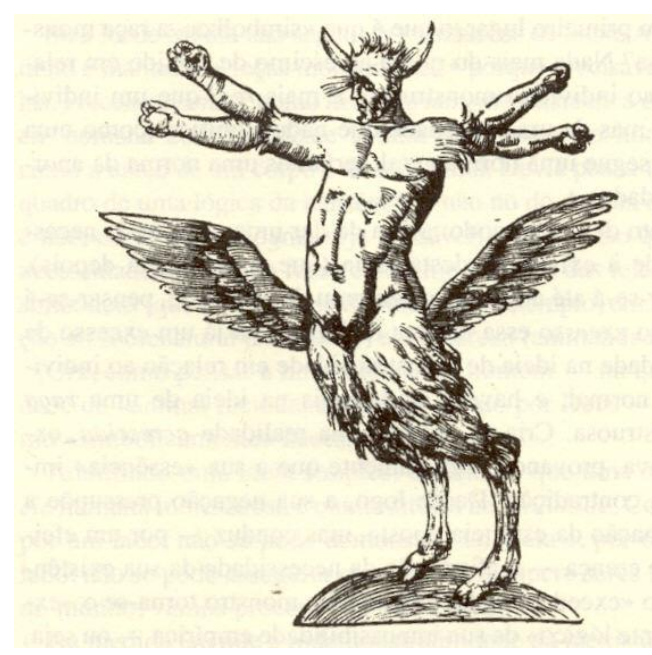

Figura 5 - Ulisses Aldrovandi. Monstrorum historia - 1642.

\footnotetext{
6. Relativo a anagogia. Arroubamento místico. Dicionário Priberam da Língua Portuguesa. http://www.priberam.pt
} 


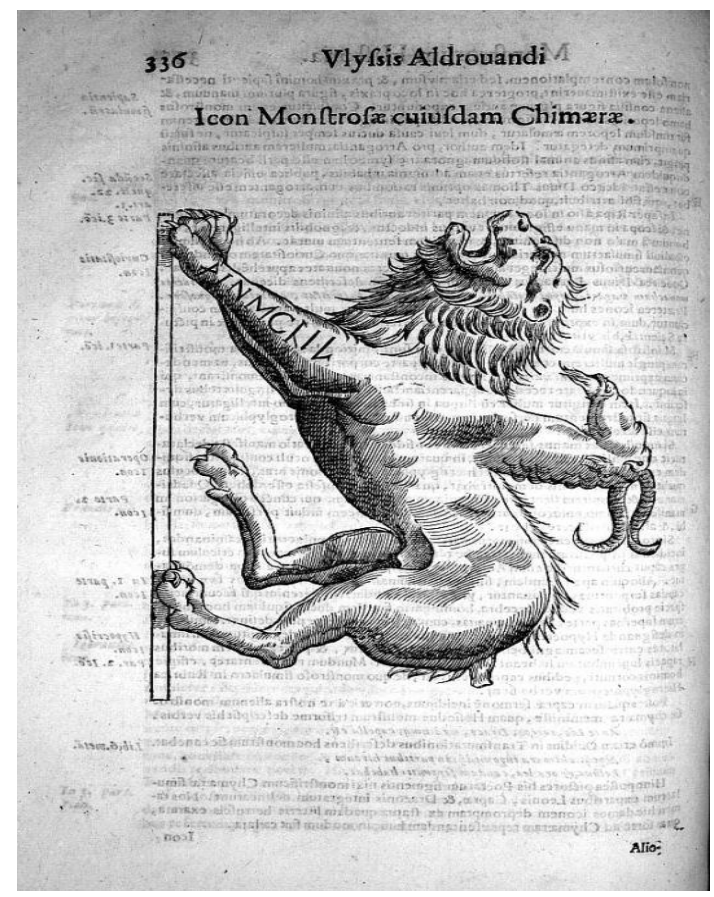

Figura 6 - Conrad Gesner. Historia animalium - 1549.
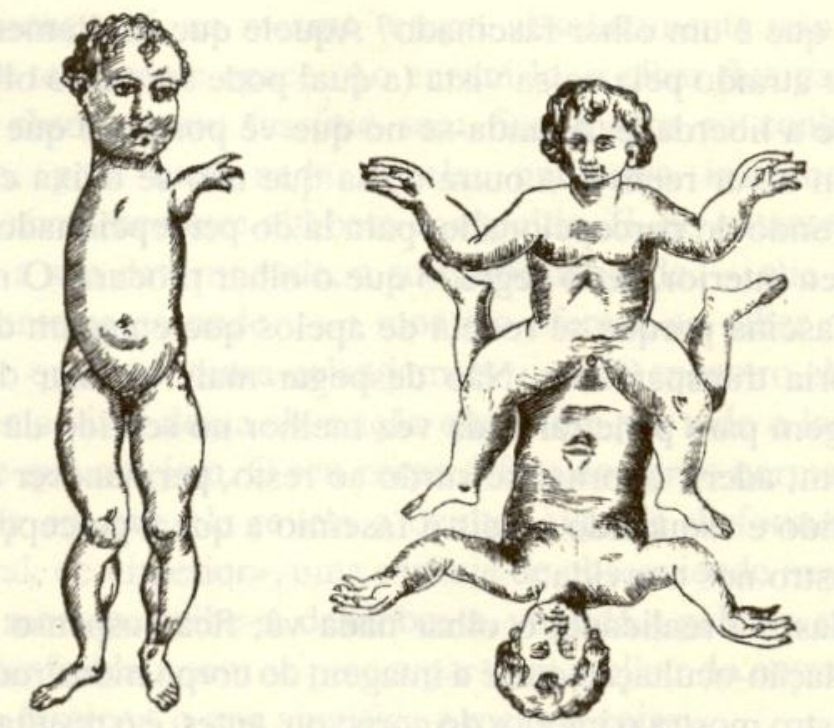

Figura 7 - Ulisses Aldrovandi. Monstrorum historia - 1642. 
No livro Des monstres et prodiges (1575), Ambroise Paré revoluciona o campo da monstruosidade no Renascimento, com relatos que "desvendam" as circunstâncias que determinam o nascimento ou o surgimento do monstro. O intuito não era confrontar descrições, discernir o verdadeiro do falso, mas fomentar o imaginário, e foi assim que identifica em um capítulo do livro treze causas da geração dos monstros: de causas humanas emolduradas por Deus até atos de inspiração demoníaca ${ }^{7}$.

Este imaginário elaborado confere um enorme sucesso de público aos Bestiários, que segundo VARANDAS (2006) está profundamente ligado à enorme importância do neoplatonismo $^{8}$ na cultura medieval e toda a realidade, incluindo a natureza e as criaturas, escondendo e espelhando uma verdade divina e transcendental. Principalmente pela teoria da emanação, ou seja, todas as coisas existentes derivam necessariamente de Deus e vão-se tornando cada vez mais imperfeitas à medida que d'Ele se afastam.

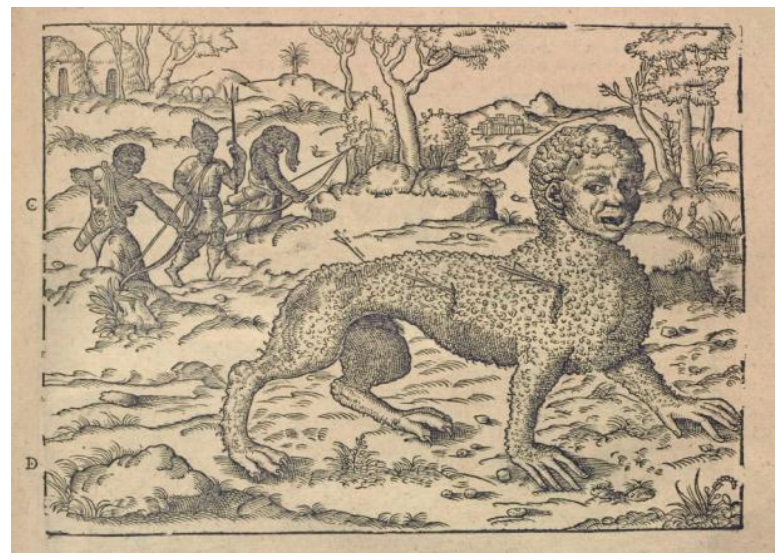

Figura 8 - Ambroise Paré. Des monstres et prodiges. Paris : Nicolas Buon - 1628.

\footnotetext{
${ }^{7}$ Primeira: É a glória de Deus; segunda causa; ira de Deus; terceira: grande quantidade de semente (sêmen); quarta, quantidade demasiado pequena das sementes; quinta, a imaginação. Sexta, a estreiteza ou pequenez do útero; sétima, o assentar-se inconveniente da mãe que, em estado prenhe, permanece sentada por longo tempo com as coxas cruzadas ou apertadas contra o ventre; oitava, por queda ou golpe dado contra o ventre da mãe que está grávida; nona, por enfermidades hereditárias ou acidentais; décima, por podridão ou corrompimento da semente; e décima primeira, por mistura ou cruzamento de sementes, décima segunda, por artifício das más disposições da parteira; e décima terceira, pelos demônios ou diabos.

${ }^{8}$ Corrente filosófica do séc.IlI da era cristã, fundada por Amônio Sacas e divulgada por Plotino e seus seguidores Porfírio, Iâmblico e Proclo (séc.V). O neoplatonismo se caracteriza por uma interpretação espiritualista e mística das doutrinas de Platão, com influência do estoicismo e do pitagorismo. Segundo o neoplatonismo, o real é constituído por três hipóteses: o Uno, a Inteligência (Nous) e a Alma, sendo que as duas últimas procederiam da primeira por emanação. E considerado um sistema um tanto obscuro, embora tenha tido grande influência no início da formação do pensamento cristão, sobretudo devido a seu espiritualismo.
} 
Durante o Renascimento, os monstros saíram da zoologia para os espetáculos e textos literários. Neste caso, exorcizar a angústia diante da insegurança política e econômica que se vivia no século XVI e no início do XVII parece ter sido uma das funções das imagens fantásticas e monstruosas ${ }^{9}$. Homens e mulheres pertencentes às classes mais baixas acotovelavam-se para ver "o nunca visto". Prodígios e monstros circulavam tanto em peças de teatro como em brochuras baratas que anunciavam nascimentos de monstros e aparições no céu. No período elisabetano, o monstruoso e o inexplicável enraizavam-se na sombra e associam-se ao imaginário noturno. E a partir destes fenômenos prodigiosos foi inserido no inconsciente coletivo o maior de todos os monstros: O Diabo, senhor da metamorfose.

\section{6 - o monstro cada vez mais perto}

No fim da Idade Média, a visão de mundo se torna mais pessimista, sombria, o que por sua vez se intensifica nas correntes estéticas. O monstro que até então pertencera a categorias naturais apresenta-se com características novas. Assistimos ao surgimento do monstro "individual”, datado, localizado, com pretensões à historicidade. Agora, o monstro exibe realidades próximas, que condena ou aprova circunstâncias presentes, que interpela um povo inteiro em nome de Deus. Diferente das monstruosidades que antigamente habitavam as fronteiras, que estavam distantes e eram justificadas por visões do mundo, através dos navegantes ou de livros (Bestiários) de conteúdo imaginativo. As fronteiras ficam cada vez mais perto, e o monstro irrompe na vida, na arte, na religião e na teologia. Com a chegada do cristianismo na cultura europeia ocorre uma profunda transformação no imaginário coletivo, redefinindo tanto as relações do homem com seu corpo, quanto à caracterização da própria natureza do mundo sobrenatural. Entra em cena a figura sorrateira e manipuladora do Diabo.

Duas representações do Diabo coexistiram nesta época: a popular, que o descreve ao mesmo tempo de forma ridícula, divertida, representado por uma forma mais humana, menos temível como assegura a Igreja e a forma erudita, mais trágica, refletida na iconografia: como um alucinante conjunto de imagens infernais, com similitudes animalescas e a ideia fixa das inumeráveis armadilhas e tentações que ele

${ }^{9}$ Del Priore cita Willy Ley, Ces bêtes qui firent nos legends, pp. 156. Paris, France-Empire - 1968. 
impele aos seres humanos. A cultura popular foi aos poucos contaminada por essas imagens, contadas pela elite instruída que consideram um dever revelar aos ignorantes a verdadeira face da identidade satânica através de sermões, obras demonológicas, catecismos e acusações.

Neste embate, o monstro e a mulher passam a constituir, sozinhos ou aos pares, um corpo poderosíssimo. O Diabo é um monstro; que se torna diabolicamente feminino. NOGUEIRA (2000, pág.42) explica que a figura do Diabo, amplificado pelo discurso da Igreja tem como uma vítima por excelência a mulher. "Porque a mulher está mais predestinada ao Mal que o homem, segundo os textos bíblicos" - Toda a malícia é leve, comparado com a malícia de uma mulher; que a sorte dos pecadores caia sobre ela! (Eclesiástico 25:26). A denúncia da mulher como instrumento para o mal e participante do complô satânico é acompanhada de um doloroso esforço pessoal. Os clérigos precisavam dar o exemplo diante da invasão demoníaca e diante da heresia. Ela é o instrumento que Satã se apropria para atrair o outro sexo ao pecado. Segundo DELUMEAU (1996), uma libido reprimida transformou-se em agressividade. Sexualmente frustrados, já que não podiam deixar de conhecer as tentações da carne, projetaram o que não queriam identificar em si mesmos. "Colocaram diante deles bodes expiatórios que podiam desprezar e acusar em seu lugar" (pág.320). Na crença de maior susceptibilidade ao demônio faz da mulher um instrumento passível de vigilância.

A associação da mulher com o pecado original cria uma falsa analogia com a luxúria, por ter apetites carnais insaciáveis que o homem não tem como saciar. Do ponto de vista masculino medieval, a mulher tem o poder de dar prazer, mas também tem o poder de retirá-lo. Este controle sobre o prazer é um poder sobre a vida, assim como pode recusar o prazer, pode retomar a vida. Assim a imagem da mãe, fecunda, acalentadora, seguidora das rígidas normas sociais contrapõe-se com a feiticeira, mulher destruidora, esterilizadora, que atua no ato sexual sugando a vitalidade do homem, anulando-o. Considerar a mulher impura é atribuir a ela atitudes tomadas diante do monstro: é relegá-la a posição em que se pode ser acusada, julgada, eliminada. Quando o mito da feiticeira se desenvolveu, a sociedade medieval conseguiu projetar seu medo da mulher, seu medo da morte, numa imagem unicamente maléfica, transformando-a num bode expiatório que carregava todas as deformidades de caráter. 
Estas pretensas afirmações sobre a demonização feminina são potencializadas pelo desenvolvimento da imprensa, que proporciona e fomenta histórias em larga escala, transmitidas de século em século, com uma constância impressionante. Histórias que enriquecem a imaginação popular sobre a monstruosidade contida na mulher, como também à medida que o contato com as literaturas gregas, árabes e as narrativas das Cruzadas aguçavam o gosto pelo exótico. Um dos livros que mais intensificam tal imagem foi o Malleus maleficarum, que dá continuidade a uma série de manuais da Inquisição, onde o discurso está repleto de caricaturas com um firme propósito de incitar o medo, um códex sobre bruxaria (ver ANEXO 1). Segundo PEREIRA JR; SILVEIRA e ROBERTO, (2007. pág.251) “[...] Malleus pode ser estudado como um dos grandes documentos de discriminação de gênero da história humana”. Simbolismo conveniente de culpa e maldição que perdura até hoje.

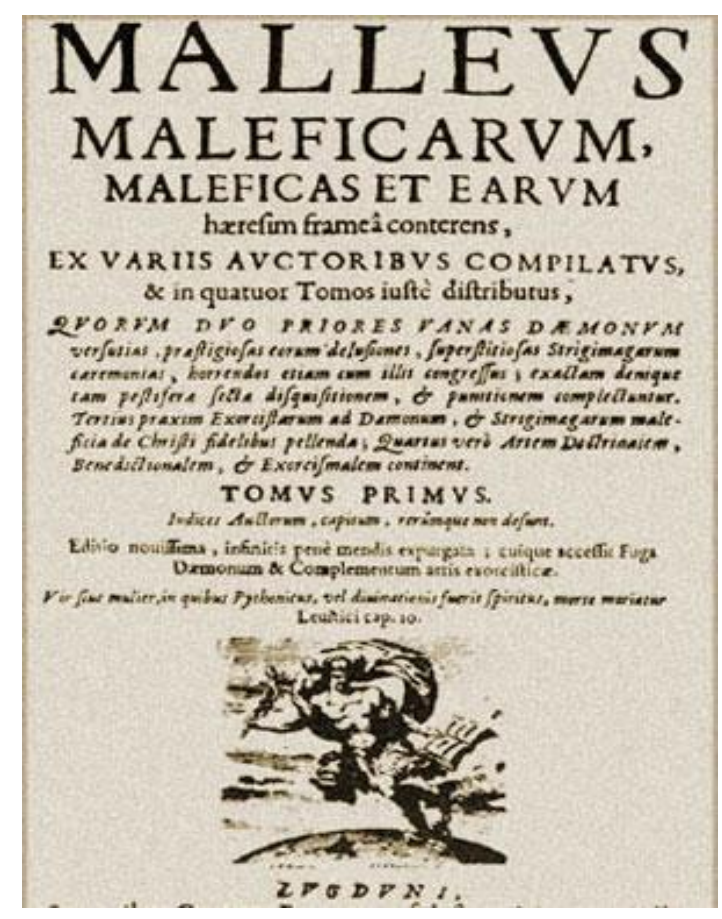

Figura 9 - capa do livro Malleus Maleficarum -1487. Strasbourg. França. 


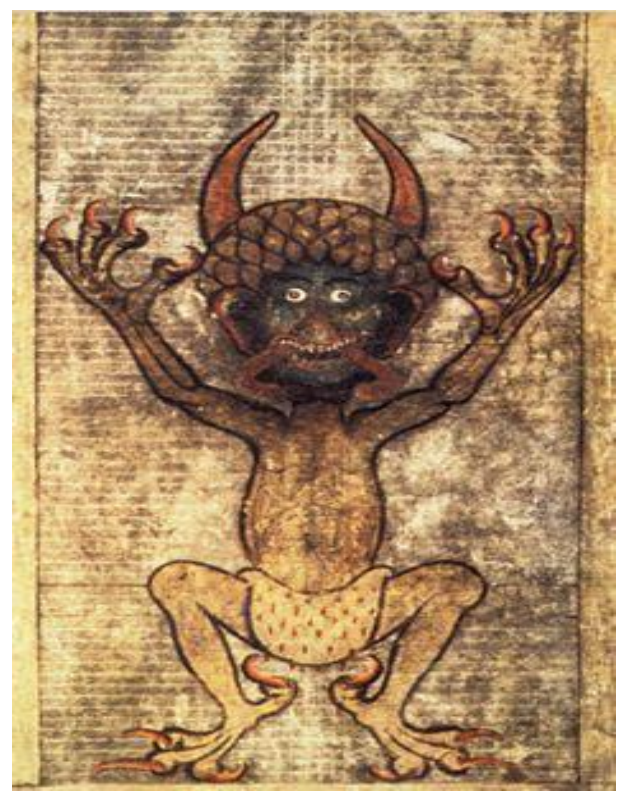

Figura 10 - Códex Gigas $^{10}$. Biblioteca Nacional da Suécia - 1200 d.C. e 1230 d.C.

Para a Igreja, o demoníaco apresenta-se sob a forma animal ou mescla-se com formas humanas, contribuindo para salientar sua natureza bestial, de acordo com a orientação canônica, mas também constitui um costume tradicional, como já verificamos, de representar seres sobrenaturais de modo monstruoso, por meio da combinação de diversos elementos da natureza. Na tradição popular da época o Diabo é claudicante, como resultado de um ferimento adquirido ao ser expulso dos céus (anjo caído). Disso resulta a crença de que seu o corpo é defeituoso, sinal claro da deformidade de toda a sua natureza. Crença que é levada para o cotidiano, em prejuízo de homens e mulheres que serão levados a justiça como agentes do Diabo unicamente por possuírem deformidades físicas.

Para estruturar todo este hibridismo disforme, o grande modelo que influenciou toda uma iconografia diabólica foram as clássicas imagens de Pã e dos sátiros: criaturas meio-homem, meio-bode, com chifres, cascos partidos, olhos oblíquos e orelhas

\footnotetext{
${ }^{10}$ O Códex Gigas (ou Bíblia do Diabo), é um volumoso manuscrito do século XIII, da Bohemia, uma das históricas terras tchecas. Famosa por seu tamanho e sua impressionante representação do diabo, em página inteira (encontrada na página 577), contém um número de partes: o Velho e o Novo Testamento, duas obras de Josephus Flavius, Etimologias de Isidoro de Sevilha, Etymologieso livro-padrão para o ensino de medicina na Idade Média conhecido como Ars medicinae (A arte da medicina), a Chronica Boëmorum (Crônica dos Boêmios) do século XII, de Cosmas de Praga e um calendário. De especial interesse são as seções que testemunham a origem boemia do manuscrito e sua história repleta de acontecimentos. No final do século XVI, o Códex foi incorporado às coleções do governante Rudolph II, da Casa de Habsburgo. Durante o cerco sueco de Praga, no final da Guerra dos Trinta Anos (1648), o manuscrito foi levado como troféu de guerra e transferido para Estocolmo.
} 
pontiagudas. A essa combinação a imaginação cristã acrescenta um ingrediente essencial: asas. Asas de anjos caídos, as que não poderiam ser de um pássaro que voa à luz do dia, e sim, as de um morcego, que ama as trevas e que de um modo absolutamente diabólico vive de cabeça para baixo. Cruz invertida, um símbolo tipicamente demoníaco.

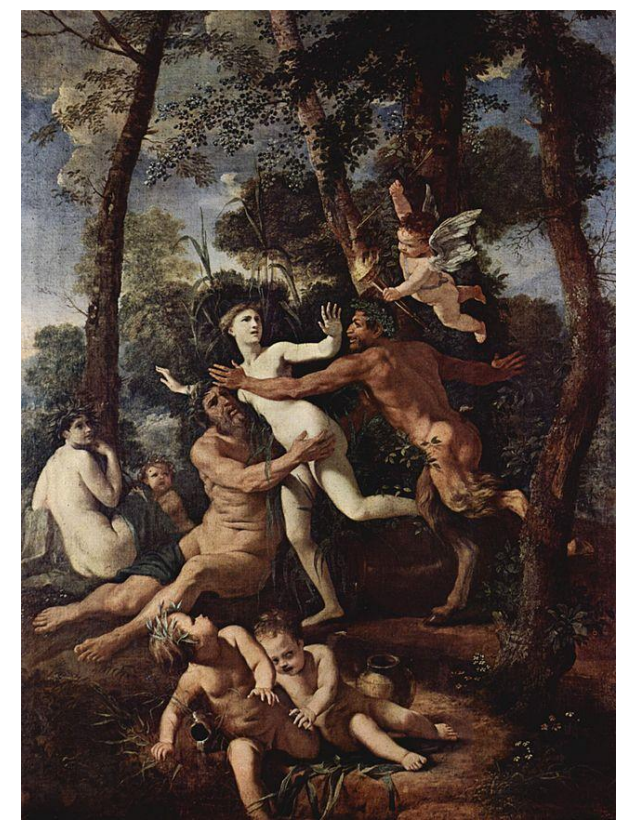

Figura 11 - Pã e Syrinx, quadro de Nicolas Poussin - 1637,

Dresden, Alemanha - Gemäldegalerie Alte Meister.

O hibridismo monstruoso de corpos e a bestialidade feminina podem ser notados também na pintura Tentações de Santo Antão, de Hieronymus Bosch (1450-1516) onde o aspecto satânico apresenta analogias feitas pelo espírito do mal e pelas forças do inferno. A obra recorre tematicamente ao eremita cristão Çakyamuni, que é submetido a uma série de provas, algumas para amedrontá-lo; outras para seduzi-lo. Ele precisa então resistir aos gigantes disformes, aos arremessos de projéteis à noite, ao ruído, ao dilúvio e as mulheres de seios nus que procuram tentá-lo. O Diabo exibe diante do eremita todos os recursos de sua arte mágica. Assim sendo, categoriza a tentação sendo mais perigosa que o tormento, daí a necessidade de prevenir continuamente os muitos crédulos humanos contra as artimanhas satânicas. 


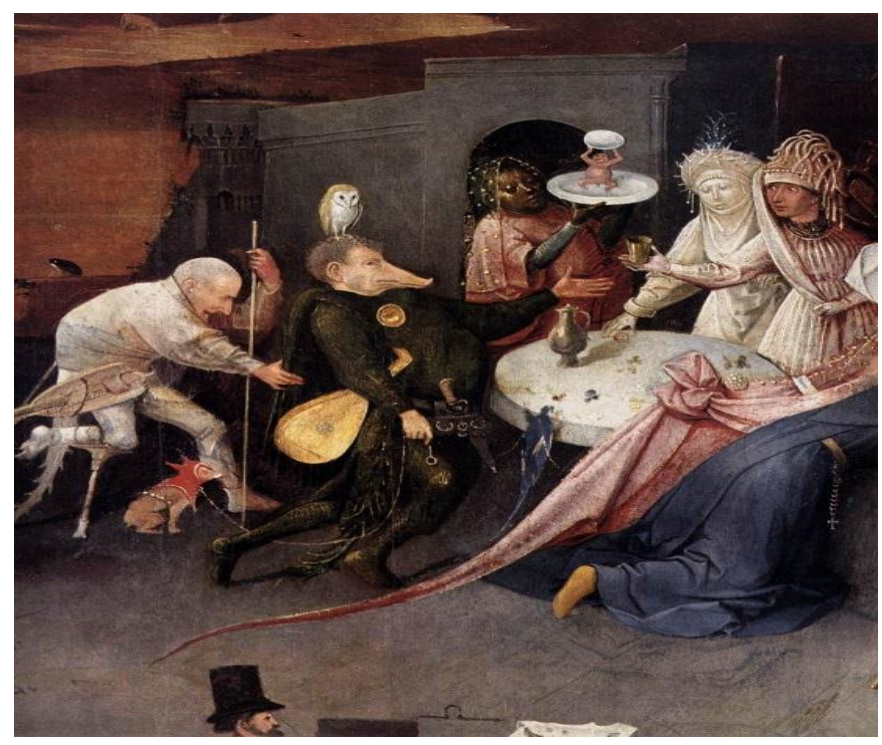

Figura 12 - As Tentações de Santo Antão (1495-1510), Hieronymus Bosh. Museu Nacional de Arte Antiga, em Portugal, (reprodução parcial).

Como ícone de controle, o Diabo atua sobre o tempo e as ações humanas devem se pautar em ações antidiabólicas: obedecer para ganhar a imortalidade. Para FLUSSER (2008) o "Divino" é concebido como algo que age dentro do mundo fenomenal, para alcançá-lo e salvar este mundo, precisamos nos transformar em um ser puro, portanto em intemporalidade. Para que se atinja esta espiritualidade para além do mundo real, é preciso lutar contra as tentações, passar por provações e dentro desta forma de pensar o dever do Diabo é manter o mundo no tempo. É uma estrutura construída para o controle, onde o mal opera através dos pecados capitais, no intuito de seduzir e aniquilar almas. $\mathrm{O}$ Diabo age no subconsciente arquetipicamente. Em sua propaganda antidiabólica a Igreja deve nomear a soberba, avareza, luxúria, inveja, gula, ira e preguiça como tentações do Diabo e criar ações de constante luta do fiel para suprimi-las, só assim ele irá retardar o Apocalipse. Desejos humanos inatos são um estorvo para as visões utópicas ou totalitárias. É o comportamento desregrado que instiga, fortalece o monstro, comportamentos pelos quais o Diabo tenta eliminar a influência divina. $\mathrm{O}$ excesso ou até mesmo a simples aceitação dele deve ser controlado para se alcançar a vida eterna. Porque agora, no comportamento se encontra o monstro. 


\section{7 - O grotesco: excessos}

O hiperbolismo, a profusão e o excesso são características do estilo grotesco, que através de imagens corporais monstruosas impetram um comportamento adquirido, transmutado. Na Renascença não apenas algo lúdico e alegre, mas seu aspecto de excesso, de algo disforme no comportamento, é algo angustiante e sinistro em face de um mundo onde as ordenações de realidade estavam suspensas, ou seja: a clara separação entre os domínios dos homens e dos animais, bem como da simetria e da ordem natural das grandezas.

Parecem mesmo proceder do universo onírico as formas em tudo dessemelhantes ao que se tinha como familiar - membra disjecta, pedaços de um corpo despedaçado, incoerentes, absurdos (PAIVA; SODRÉ, 2002.pág.30).

O disforme (conexões imperfeitas) e o onírico (conexões irreais) ampliam as transformações metafóricas ao longo dos séculos. Do seu uso como substantivo, restrito à avaliação estética de obras-de-arte, o grotesco torna-se adjetivo a serviço do gosto generalizado, do gosto popular e é capaz de qualificar - a partir de conflitos entre o centro e margem ou a partir do equilíbrio precário de formas - figuras identificadas da vida social, onde discursos, roupas ou comportamento se sobressaem.

O grotesco herda do monstro seu excesso e gera a sensibilidade espontânea de uma forma de vida. Nas palavras de PAIVA; SODRÉ (2002. pág.38), "é algo que ameaça continuamente qualquer representação (escrita, visual) ou comportamento marcado pela excessiva idealização. Pelo ridículo ou pela estranheza, pode fazer descer ao chão tudo aquilo que a ideia eleva alto demais". Mais do que enquadrá-lo nas categorias do cômico, da ironia ou da sátira, o grotesco esconde algo de sinistro, que se acha em secreta aliança com as fatalidades reais e alienantes entre os homens. Em seu conceito manifesta-se o caráter insondável, abismal e mediador diante do horror da fragmentação. 
Percebe-se um aspecto de descrição anatômica e transmuta-se a hierarquia corporal: o baixo toma lugar do alto, assim excrescências, atos escatológicos, palavras de baixo calão tem um valor especial, o de reunir num só corpo o mundo não-corporal. O corpo grotesco jamais está pronto nem acabado, está sempre em estado de construção, de criação, onde absorve o mundo e é absorvido por ele. Ele é bicorporal, um fenômeno em perpétua renovação. O escatologismo medieval suscitava o riso, onde elementos da linguagem corporal criam uma atmosfera licenciosa, a maioria ligada ao "baixo" material, onde se rebaixam os atos nobres dissimulados, misturam o corpo no mundo preparando desta forma a transformação.

[...]o fundo incessante de monstruosidades que aparecem, cintilam, caem em ruína e por vezes se mantêm. E aí está o ponto fundamental: a natureza só tem uma história na medida em que é suscetível do contínuo. É porque ela assume, um a um, todos os caracteres possíveis (cada valor de todas as variáveis) que se apresenta sob a forma da sucessão. (FOUCAULT, 2000.pág.207-213).

Nos planos constitutivos da estética grotesca, existe uma constância a se observar de três características que se repetem: criação, composição e efeitos. $O$ primeiro pelo caricatural e satírico frente à visão desencantada da vida. O segundo, pelo fato do monstruoso (sob formas humanas, animais, vegetais ou mesmo maquínicas) se destacar como traço mais constante. Em seu clássico As Palavras e as Coisas, Michel Foucault vê na "[...] monstruosidade uma espécie de ruído de fundo, o murmúrio incessante da Natureza", necessário como exemplo de variedade de forma ou metamorfose do protótipo, para que se torne visível a continuidade da espécie humana. E por último, o grotesco seja pelo risível ou pelo monstruoso produz o efeito de estranhamento, uma sensação de absurdo ou de inexplicável. O conceito freudiano de Uhheimlich, que se traduz por "inquietante familiar", é algo que deixamos de reconhecer como identidade normalizada, por efeito de forças obscuras e incompreensíveis. Temos a propensão de caracterizar aquilo que é "estranho" e assustador por não ser exatamente conhecido e familiar. Refere-se a tudo que estava escondido e veio à tona. $\mathrm{O}$ contraste entre o que foi reprimido e o que foi superado não pode ser transposto para o estranho na ficção sem modificações profundas. Ou seja, há um paradoxo: muito do que acontece na ficção seria estranho caso acontecesse na vida 
real e que também existem meios de criar estranhamentos na ficção, mais do que na vida real.

O monstro teratológico ou a crença no Diabo envolve um controle de ideais tanto externos como internos. O medo de tudo é imenso e fortemente ditado pelos sistemas religiosos com o fim de oprimir o homem, de dominar sua consciência. A comédia grotesca exagera caricaturalmente um fenômeno social negativo, levando os vícios ao extremo. Reconhece-se a imoralidade e a corrupção através de uma imagem impossível e inverossímil. Um jogo eterno entre descontentamento e prazer. O primeiro, pelo relato de forma absurda e contundente da falha moral; e o segundo pela experimentação de uma satisfação pela caricatura e ridicularização da imoralidade. $\mathrm{O}$ grotesco é uma forma de destronar e renovar todo o mundo das concepções e das estruturas medievais, que moldavam comportamentos através da fé, seus santos, relíquias, da falsa ascese e seus monstros.

O grotesco é uma inversão de parâmetros, o monstro agora volta-se contra o sistema constituído, pagando na mesma moeda: o excesso para colocar em xeque suas verdades. A monstruosidade sob a forma do comportamento representa o pensamento da filosofia humanista do Renascimento e reestrutura o cosmos da verticalidade à horizontalidade em torno do homem e do corpo humano. Radiografia inquietante do real, o grotesco impele o homem, movido pelo desejo de ultrapassar os instintos pelas pulsões e ingressar-se na cultura, num universo não só das transposições, mas também de regras e contenções. O monstro encontra um novo formato: exceder pelo espetáculo passível do riso.

\section{8 - A Teratologia como diversão. Os freak-shows}

Os arquétipos não são apenas impregnações de experiências típicas, incessantemente repetidas, mas também se comportam empiricamente como forças ou tendências à repetição das mesmas experiências. Cada vez que um arquétipo aparece em sonho, na fantasia ou na vida, ele traz consigo uma "influência" específica ou uma força que lhe confere um efeito luminoso e fascinante ou impele à ação. 
Na segunda metade do século XIX a curiosidade, quase universal, pela anatomia humana e por suas deficiências culmina na criação, por volta de 1840, em Nova York, do primeiro Museu de Teratologia. Esta fascinação pelo bizarro, por corpos deformados terá seu auge até a Primeira Guerra Mundial, com sinais de esgotamento em 1930 e se extinguirá a partir do fim da década de 40.

COURTINE (2006. pág.253) relata que o diretor de um circo de curiosidades pede permissão para exibir "uma moça-macaco (microcepohalus) da Albânia". Segundo ele: "Ela vai ser apresentada ao público em local conveniente, e de maneira que não ofenda os bons costumes" $" 11$. Desta forma, na virada da década de 1880 procurase exibir todo tipo de criaturas bizarras para o entretenimento do público nos chamados "entra-e-sai" (entre-sorts). Nome que se dava ao incansável observador das estranhezas anatômicas que povoavam as feiras, as ruas parisienses, o teatro, numa cortina ou numa barraca, O entra-e-sai é uma palavra que define bem este fenômeno, uma vez que, o público entra, a peculiar criatura se apresenta, emite um balido ou fala grotesca e o público se retira. Simples: entra e sai. Os monstros das feiras possuíam a banalidade rotineira dos divertimentos familiares e incitavam o risível e a estupefação alheia (ver ANEXO 2). De prodígio com Aristóteles a status de mirabilia com Santo Agostinho, na Idade Moderna, o monstro tende a banalização.

Nessas festas do olhar, as pessoas rendem-se a curiosidade destes estranhos seres deformados e os olhares capitalizam um inventário sem limites de bizarrices do corpo humano: "fenômenos vivos", deformações humanas, animais extraordinários; espécimes teratológicos em frascos de vidro, patologias sexuais dos museus de cera anatômicos; morfologias exóticas e rituais selvagens dos "zoos humanos"; truques e ilusões de ótica: "decapitados falantes", "mulheres-aranhas" ou "mulheres-lunares"; museus realistas com seus fatos do dia sangrentos, ou episódios da vida. Num misto de casa dos horrores, antropologia sem fundo científico, feira de órgãos e de um museu dos horrores, o espetáculo dos monstros rendia muito dinheiro.

\footnotetext{
${ }^{11}$ Arquivos da Diretoria de Polícia da Prefeitura de Paris [APP], DA 127. Dossiê: exibição da mulhermacaco (Claessem).
} 


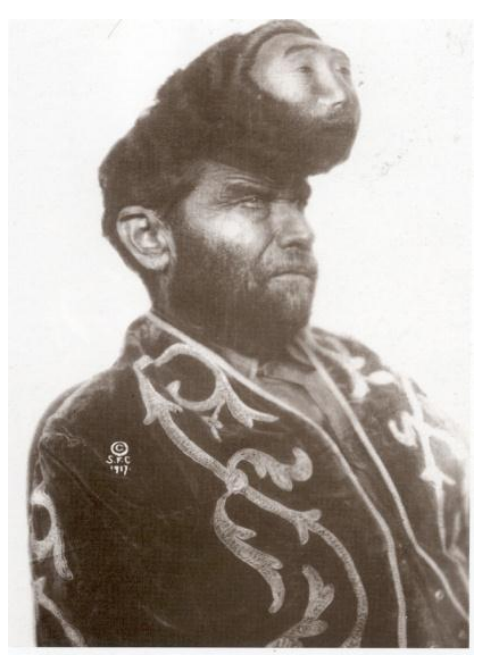

Figura 13 - Pasquel Penon, o homem de duas cabeças, nasceu no México em 1862. Trabalhou até que a cabeça de cima sofreu um ataque de paralisia, deixando-o mentalmente afetado. A partir de então, começou a atuar no Sell's Circus - 1917. Coleção Akimitsu Naruyama.

Nessa espécie de "Disneylândia teratológica", o corpo monstruoso é uma imagem bizarra, suscita o interesse de famílias e trabalhadores, o que possibilita um lucro marginal em uma microeconomia da curiosidade. Longe de ser uma atividade marginal ou duvidosa, os freak-shows serviram de laboratório, onde a exibição do corpo humano no espaço urbano, sua constituição anormal, suas deformidades, distorções, mutilações e disfunções constituía o suporte principal de espetáculos, onde se experimentaram as primeiras formas de diversão da indústria moderna. Os astros deformados dos Freak-shows foram os primeiros atores contemporâneos da diversão de massa na América do Norte e, em proporção menor, na Europa.

Os monstros aparecem em carne e osso, multiplicam-se, são objetos de exibição, e por toda a parte o grotesco prolonga o gosto ao exótico e ao prestigioso, sem se dar conta até que ponto essas formas lhes são necessárias. Sejam os irmãos siameses, a mulher barbada, o homem-elefante ou qualquer anormalidade física da forma humana apresentam-se de forma real ou inventada - pelas leis da natureza. Um perturbador espetáculo $^{12}$ do "valor negativo" de seres vivos, um misto dos reinos animal e o reino

\footnotetext{
12 Em 1841, Phineas Taylor Barnum funda, bem no coração de Manhattan, seu American Museum. Segundo COURTINE (2008.p.265) o museu, até a data de 1868 quando um incêndio o destruiu, era a atração mais frequentada da cidade e do país inteiro, onde estima-se cerca de 41 milhões de visitantes neste período. A ideia de Barnum foi unir os museus de curiosidades, que apresentavam coleções de historia natural e já existiam desde a Guerra de Secessão, com o freak shows que continham uma série de anomalias do corpo humano. Fundir os dois tipos de estabelecimento foi uma estratégia comercial de
} 
humano, que desperta as mais variadas percepções por parte da audiência com rompantes de repúdio, espanto e estupefação. Para FOUCAULT (2001) na mistura entre duas espécies, entre dois corpos e uma cabeça ou duas cabeças e um corpo, na combinação entre sexos, num misto de formas encontra-se o monstro.

Com os progressos da medicina no início do século XIX, a percepção da deformidade humana, sempre associada à figura do monstro, começa a se fragmentar. De duplo grotesco, pai bestial ou negação viva do homem, o corpo enfermo vai progressivamente se dissociar do corpo monstruoso. Isso se dá pelo fato da invenção da teratologia científica, baseada nos progressos da embriogenia e da anatomia comparada.

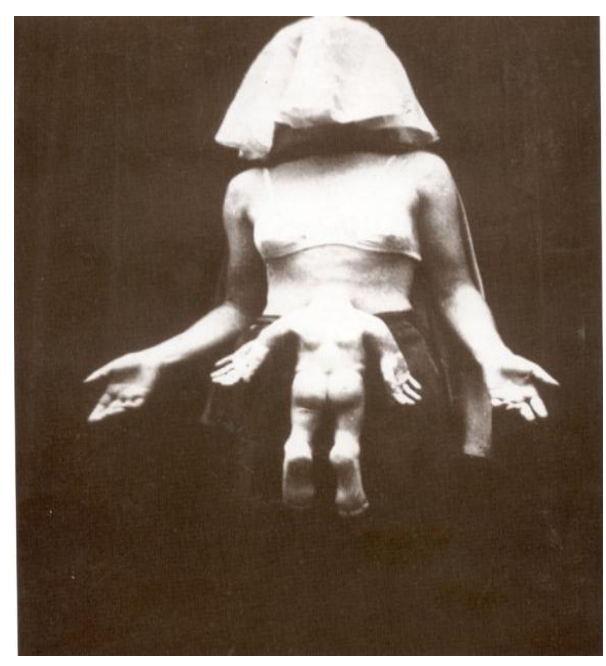

Figura 14 - Mulher não identificada com um bebê gêmeo siamês crescendo para fora do seu abdômen; a cabeça cresce por dentro do seu corpo. A mulher chama-se, provavelmente, Margaret Clark - 1947. Coleção Akimitsu Naruyama.

Uma ciência autônoma das anomalias organiza uma nova forma de pensar o monstruoso e abala o olhar sobre este corpo deformado. A medicina e a biologia se apoderam do monstro por intermédio dos avanços da genética e da embriologia que geram questionamentos científicos: o monstro pode ser agora fruto de mutações

grande êxito pelo fato da população nova-iorquina estar em pleno crescimento. "Imigrantes recémchegados, classes laboriosas e estratos médios, homens e mulheres, habitantes da cidade e visitantes que vinham do interior da América rural. E, nas cenas e nas galerias do American Museum, são precisamente os monstros que constituem a maior atração do espetáculo. No prédio da Broadway, muita gente vai passar o domingo em família e fazer piquenique em companhia dos fenômenos vivos, para a grande alegria das crianças e edificação geral". (COURTINE, 2008:266-267). 
provocadas em laboratório. A representação dos monstros humanos torna-se um conflito entre uma cultura do voyeurismo e uma cultura da observação científica.

Este conflito, esta mudança de olhar encontra-se também contida no Manifesto Futurista, assinado pelo poeta Filippo Marinetti que enaltece com exacerbado fervor como a tecnologia industrial poderia realizar uma "higiene do mundo", com a ajuda de artefatos mecânicos, a fim de criar um novo tipo de ser humano. "Essa higiene científica aplicada ao corpo prometia depurar as suas falhas ancestrais e aprimorar a velha configuração de carne e osso, contribuindo para o surgimento de uma nova subjetividade mais adequada ao novo tecnomundo[...]" (SIBILIA, 2003, pág.86). A visão tecnocrata espalhava-se pelo mundo a partir das fábricas, das estradas de ferro e das grandes obras de engenharia da época.

\footnotetext{
Vamos, disse eu; vamos amigos! Partamos! Finalmente a mitologia e o ideal místico estão superados. [...] Será preciso sacudir as portas da vida para experimentar seus gozos e ferrolhos! [...]. Nós cantaremos as grandes multidões agitadas pelo trabalho[...], dos estaleiros incendiados por violentas luas elétricas[...], as oficinas penduradas às nuvens as locomotivas de largo peito[...], como uma bandeira, aplaudir como uma multidão entusiasta. ${ }^{13}$
}

Se os avanços da ciência estabeleceram mudanças sobre a visão da deformidade, isto se alteraria profundamente diante das atrocidades da Primeira Guerra Mundial. Grande número de mutilados volta à sociedade, e tal experiência com relação à amputação, o corpo desmembrado e olhar cotidiano de cadáveres, aliado a profundidade do trauma e do sofrimento psicológicos registram a desfiguração e ferem a percepção do corpo no seio da sociedade. Para COURTINE (2008), a deficiência corporal entra então simultaneamente em um universo de culpa e de obrigações morais. A sociedade irá reconhecer o pesado fardo que estes homens pagaram em batalha e ocorre uma cisão entre a imagem do monstro e do enfermo. O período entre as duas grandes guerras irá

\footnotetext{
${ }^{13}$ Manifesto Futurista, escrito pelo poeta italiano Filippo Tommaso Marinetti, e publicado no jornal francês Le Figaro em 20 de fevereiro de 1909. Este manifesto marcou a fundação do Futurismo, um dos primeiros movimentos da arte moderna. Consistia em 11 itens que proclamavam a ruptura com o passado e a identificação do homem com a máquina, a velocidade e o dinamismo do novo século.
} 
substituir o enfermo pelo mutilado, a invalidez será uma insuficiência a compensar e tal lógica se estenderá até a Segunda Guerra Mundial.

Ao não enxergar o monstro como um enfermo, mas sim como um mutilado, que deve ser compensado e algumas vezes até vê-lo como semelhante em devir, o voyeurismo que o público exibia anteriormente já não se sustenta como inocência cruel ou indiferença lúdica. Depois da Segunda Grande Guerra tais exibições de monstroshumanos desapareceram, pois anteriormente a guerra, o vínculo do espectador era fraco com relação ao objeto de exibição. Ir aos freak-shows era um passatempo, uma fuga do dia a dia e só a partir do momento em que o homem/espectador reconheceu a monstruosidade como algo humano, sua exibição começou a declinar. O monstro deixa de ser lucrativo e o espetáculo teratológico cede espaço às ilusões de ótica. Dispositivos engenhosos de espelhos projetam agora a deformidade do corpo, onde o simulacro é introduzido nas convenções visuais da época. O corpo é dotado de uma segunda vida, cuja presença e complexidade o cinema das primeiras décadas irá intensificar. A partir daí assumem na tela o papel de instrumento gestor emocional da sociedade. Para COURTINE (2008), o espetáculo oferecido por esses rituais de catarse dos medos coletivos, conhecidos como filmes de terror, é agora permanente, mas seu poder de desestabilização do olhar é bem menor do que aquele que, ainda ontem, surgia com a simples presença dos fenômenos vivos.

Com a invenção do cinematógrafo, os monstros deixam os entra-e-sai e invadem as telas. Os parques de diversão nas duas primeiras décadas do século XX transformamse em estabelecimentos cinematográficos itinerantes e multiplicam os corpos monstruosos. Nestes primeiros anos, o cinema primitivo aposta nos filmes de terror, demonstrando uma ligação estreita com a cultura do horror dos parques e a teatralidade sangrenta do Grand Guinol. Filmes como O gabinete do Dr. Caligari (1919) e Nosferatu (1922), provocam um choque nos espectadores e instala-se na cultura visual dos anos de 1920 um gênero que se abastece com seus monstros oficiais, que vão reaparecer sempre mais tarde, os 'revenants'. "No sentido literal do termo [revenant, de revenir: o que vem de novo, o que retorna, o que aparece de novo [...] da tela grande e depois da telinha. Frankenstein, Doutor Jekyll e Mister Hyde, Drácula, etc”. (COURTINE, 2008.p.320). 
Um fato importante que redefine o papel do monstruoso nas telas e o apresenta estilizado é o primeiro longa-metragem da Disney, Branca de Neve e os Sete Anões (1938), que desceu os anões do tablado do freak-show para transformá-los em produtos de consumo para o universo infantil. O sucesso da Disney na segunda metade do século XX é o ponto de ruptura entre o espetáculo de deformidades corporais e o recalque em escala industrial das sensibilidades. Disney percebeu o quão vantajoso seria associar a imagem das ficções monstruosas a artigos de consumo para todo tipo de público: com a venda de bonecas, bombons, pingentes, brinquedos de celuloide, barras de chocolate, álbuns de figurinhas, lenços, lingerie, gorros e bonés e tema de parques de diversões. $\mathrm{O}$ monstro volta a ser lucrativo.

O monstro dos entra-e-sai agora é uma enxurrada de signos que transbordam nas telas o que irá gerar consequências políticas. "As sociedades democráticas de massa quiseram transformar o corpo anormal em corpo ordinário" (COURTINE, 2008, pág.335). Tornaram deste modo o campo de conflito entre razão política e visão singular: a primeira requer que se tratem de modo igual os indivíduos seja qual for a sua aparência, enquanto a segunda registra a perturbação do olhar diante dos desvios do corpo.

O triunfo da Disney assinala o fim da separação do espetáculo da monstruosidade para o de gestor emocional das massas. $\mathrm{O}$ que antigamente incitava $\mathrm{o}$ medo coletivo através dos monstros clássicos, agora sensibiliza o olhar através da benevolência, da fantasia. De espetáculo risível e curioso até o monstro dócil, o efeito monstruoso de controle caminhou à pasteurização, como ícone da cultura popular. Ele infringe outro tipo de medo, não àquele de postura social comedida e imposta, mas sim, o medo de não consumir o produto que traz sua imagem, Ele é desejado, precisa ser consumido, onde o conceito de controle está inserido em outro formato: o econômico. 


\section{9 - Monstros híbridos: Body-builders, ciborgues e mutantes}

Estigmatizado por séculos pela tradição judaico-cristã, o corpo e seu duplo foram objetos de exaustiva atenção, "Este corpo [...] uma obscena massa de carne e imagem de um espírito divino", (VILLAÇA, 1998, pág.57), representado pela figura austera, física e moralmente perfeito do herói em contraponto ao vilão, feio, deformado moral e fisicamente ditam respectivamente o bem e o mal. No século XX a paixão por conhecer este corpo, por compreender seus mecanismos acentua-se produzindo novas visibilidades do homem e da sociedade, novas armadilhas numa incessante criação monstruosa, mutável, mas condizente com o pensamento científico instaurado.

O corpo e suas deformidades sejam por vias burocráticas, médicas ou publicitárias, enquadram um paradigma incessante de novas configurações, reais ou ilusoriamente produzidas. Destarte, cria-se um paradoxo, onde o discurso de tolerância e compaixão pelo corpo anormal convive com o fluxo de submeter esta realidade a uma estigmatização do defeito. A partir deste pensamento, a deformidade e a feiura, conceitos de monstruosidade, são constantemente incutidos na comunicação de massa através da produção industrial que avaliza o consumo e encanta com produtos dedicados ao corpo, como moda, cosméticos e pela força das mídias que entram na vida privada das pessoas e despertam sonhos e desejos de transformação.

O body-building ganha espaço na era pós-industrial pela espetacularização do corpo, o homem mecânico dos anos 30 retorna sob a forma da eficiência esportiva, onde o monstruoso torna-se manifestação da perfeição sem norma. Corpo construído, vivo, objeto para ser visto tem suas raízes em uma série de circunstâncias, "[...] o movimento de cultura física germânica, a influência emergente do palco popular como espaço de exposição [...] e a crescente importância da fotografia como meio de contemplação estética [...]" (VILLAÇA.1998, pág. 60). O surto hedonista de 1960 modela a sua identidade através de músculos como produção pessoal e dominável. Trata-se de fabricar a si mesmo. Em 1980 existe um desejo pelo corpo liso, pelo polido, pelo esbelto, em contraste com tudo que aparente relaxado, franzido, machucado, amarrotado, enrugado, pesado, amolecido ou distendido. A projeção de uma autoestima dedicada a simulacros é ambígua por se caracterizar pelo prazer e o sofrimento. A ideia da metamorfose é essencial, como também os excessos que tal prática acarreta. 
Fundamentos do monstruoso, com a roupagem adequada ao pensamento narcisista introjetado numa verdade fabricada pela propaganda que ditas normas estéticas e comportamentais.

[...] "Verdade" [...] conjunto de procedimentos regulados para a produção, a lei, a repartição, a circulação e ao funcionamento dos enunciados. A "verdade" está circularmente ligada a sistemas de poder que ela induz e que a reproduzem. "Regime" da verdade". (FOUCAULT, 2010, pág. 11)

O espetáculo de corpos apresenta-se grandioso, positivo, indiscutível e como projeto a ser acessado, o que aparece é bom, porque o bom aparece. Exige uma atitude passiva como monopólio da aparência. O corpo trabalhado pelo condicionamento físico até as modelagens de implantes, enxertos e cirurgias plásticas são a forma de entrada ou adaptação deste corpo aos padrões estéticos em vigor. Para LE BRETON (2003) o discurso científico contemporâneo do corpo é pensado como objeto ontologicamente distinto do sujeito, como matéria-prima a ser melhorada, "declinado em peças isoladas", que pode ser substituído, remanejado seja por motivos terapêuticos ou por simples vaidade pessoal, um rascunho a ser modificado. $\underline{\text { Um corpo remodelado }}^{\mathbf{1 4}}$.

$\mathrm{Na}$ body art entra a materialidade do corpo, o questionamento deixa de ser afirmação do belo para ser provocação da carne, onde virar o corpo do avesso, confere o nojo ou o horror e o reivindica como fonte de criação. Neste conceito, para a artista francesa Orlan ${ }^{15}$ o corpo é um templo de profanação. Em suas performances reinventase, ao estabelecer um elo entre a desfiguração e uma nova escrita no corpo, ao criar uma nova criatura, um ser híbrido, grotesco, neoteratológico. Seu corpo é um ready made que deve buscar novas versões, autorretratos onde a artista através de cirurgias plásticas, sem referências à enfermidade ou sofrimento moral experimenta os possíveis corporais.

\footnotetext{
${ }^{14}$ Grifo meu.

${ }^{15}$ Realiza trabalhos em vídeos, fotografias, performances e instalações, explorando o seu próprio corpo como uma superfície de transformação e de criação. Criadora do "manifesto da arte carnal", autoretrato clássico passeando entre desfiguração e figuração. O seu trabalho tão radical procura realizar questionamentos sobre o status do corpo na sociedade. http://www.orlan.ne
} 
A tarefa não é estética, nem lutar contra o envelhecimento e sim construir um corpo arbitrário que não necessita prestar contas a ninguém. E neste corpo, nesta colagem obscura, estreita-se a linha tênue do homem e do monstro. Homem monstruoso ou monstro humanizado? "Orlan sonha com uma intervenção cirúrgica que lhe permita construir o nariz mais comprido possível. A máscara não é mais um acréscimo ao rosto: torna-se o próprio rosto e dissolve-se como máscara”. (LE BRETON, 2003, pág. 49).

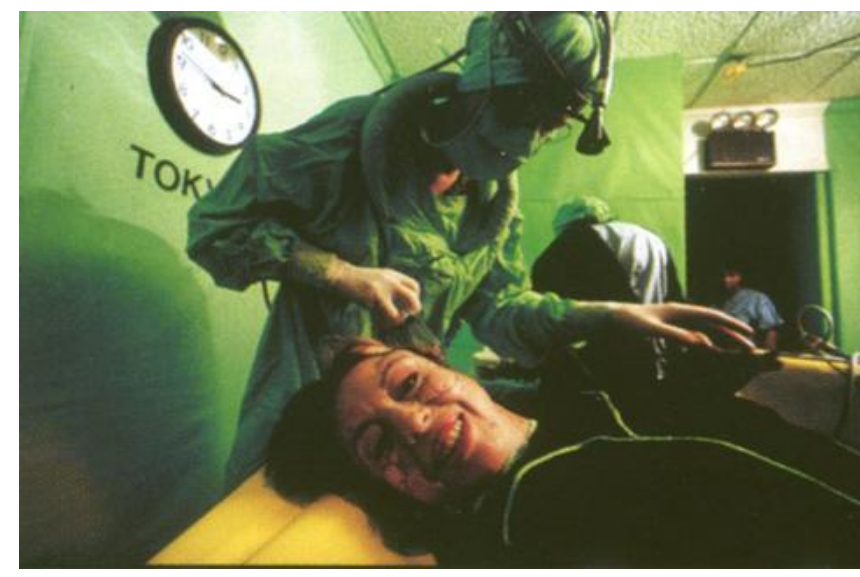

Figura 15 - ORLAN, The Reincarnation of Saint Orlan, (1990 - 1993). Depois das operações @ ORLAN

Descartes, no século XVII, já pensara no corpo como máquina, desligando a inteligência do homem da carne. A metáfora mecânica contemporânea ecoa também neste sentido indagando ser preciso uma reparação, uma mudança, para que o corpo atinja sua perfeição. Corrigir este corpo é torná-lo uma máquina ou acoplá-lo a ela. Sendo assim, a precariedade da carne, sua falta de durabilidade, imperfeições e ausência de confiabilidade em seu desempenho são os "defeitos" que serão solucionados através da genética, robótica ou informática. O tempo pós-biológico, pós-orgânico. Corpo protético $^{16}$.

Enquanto no corpo remodelado as alterações são externas, o corpo protético estabelece uma ligação com o interior, com implantes de biochips e próteses artificiais.

\footnotetext{
${ }^{16}$ Grifo meu
} 
Entretanto, para SANTAELLA (2004) é preciso notar a diferença entre uma prótese e um sistema artificial autônomo (androide). Uma prótese é uma parte, um suplemento que não é complexamente integrada. É uma parte artificial complementar que executa um sistema de operações diferentes do sistema orgânico do corpo. Atualmente, qualquer parte do corpo, exceto o cérebro e o sistema nervoso, é passível de substituição protética e nesta categoria habita a figura do ciborgue.

Além de um fato científico, o ciborgue é uma criatura da imaginação da literatura médica ocidental, que busca a possibilidade de fuga de nossas próprias limitações corporais. Isto fez com que militares americanos em 1960 canalizassem verbas para projetos de construção de exoesqueletos e braços robóticos. Entretanto, para HARAWAY (2009) o ciborgue de hoje é bem diferente de seus ancestrais mecânicos, são "máquinas de informação" e trazem consigo sistemas autônomos de controle. Juntas pélvicas artificiais, implantes de tímpanos para surdos, implantes de retina para cegos anunciam fronteiras transgredidas e perigosas possibilidades.

Exemplo vivo deste conceito, o artista-performer australiano Stelarc leva a cabo a concepção mcluhiana pelas quais as máquinas são extensões do nosso corpo, ao utilizar em seus trabalhos instrumentos médicos, próteses, procedimentos de robótica e sistemas de realidade virtual explorando interfaces entre a tecnologia e seu corpo. No final de 1970, um engenheiro japonês especializado em robótica, construiu para Stelarc uma terceira mão do mesmo tamanho de sua mão direita. Presa ao corpo através dos braços, essa mão é ativada diretamente pelos sinais elétricos dos músculos do seu abdômen e das pernas, gira o pulso, como também pode agarrar e soltar coisas. Foram meses de aprendizado para manejar o mecanismo e foi necessária uma recognição do controle do sistema nervoso central. Na criação deste ser amplificado, homem-máquina, o interesse é alterar, introjetar e provocar as percepções sensórias desta experiência. Para Stelarc, o corpo está obsoleto, em sua forma biológica e precisa ser readaptado para transcender. Da ficção científica surge o ciborgue, o sonho de integração entre dois mundos. 


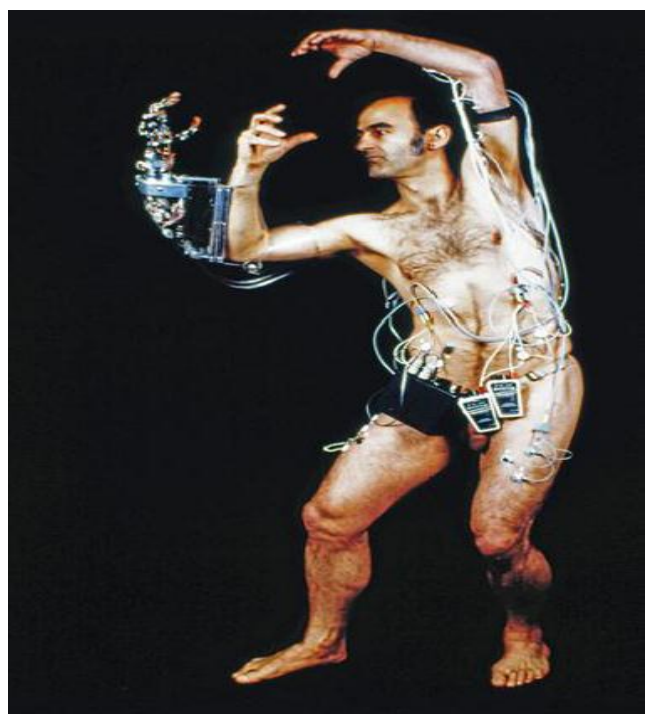

Figura 16 - Stelarc. Third Hand - 1981

À medida que aumenta o poder de manipulação de objetos em escala molecular, as diferenças microfísicas entre o biológico e inorgânico tendem a se reduzir, ocorrendo uma integração maior entre os componentes orgânicos e os criados artificialmente. Nesta vida de síntese, os ciborgues não temem uma afinidade com animais ou máquinas, numa cultura humana cumulativa, onde novas formas, ideias, imagens, técnicas, modos de vida surgem e se misturam vertiginosamente na mesma proporção que a nanotecnologia miniaturiza a vida.

De portento a mirabilia, de seres imaginários contidos em grandes Bestiários ao senhor das trevas, do grotesco aos freak-shows, os monstros do século XX transmutaram seu excesso, sua duplicidade na diferença, sua espetacularidade, num hibridismo tecnológico, numa fronteira entre o natural e o artificial. A monstruosidade assume uma nova face diante das transformações corporais,consciente ou inconscientemente, mutam de acordo com as sociedades disciplinares ou de controle, onde os conceitos do monstro, através do tempo, estimularam à atenção, a vigilância, a curiosidade, a inquietação e os modos de conhecer através do incerto, do vago, do risco. Para FOUCAULT (2000), os monstros são personagens para serem repensados, onde cada época constrói a sua própria versão. Os mitos atravessam os tempos, mas trocam de roupa. Cada geração o deforma, o recicla e introduz algo novo segundo sua vontade. Cada vez mais o monstro de carne e osso contemporâneo abre espaço para a criatura 
digital, onde o artista-cientista deixa de lado os pedaços de corpos para viver sua duplicidade em pixels entrelaçados: "Frankentecnosteins" ou "Digital Ghosts". O monstruoso assinala momentos de desconstrução e reconstrução da subjetividade, valoriza e ao mesmo tempo recusa o corpo em todos seus limites. O monstro contemporâneo, pós-humano é uma tecnologia que se afirma como máscara, como objeto de novas subversões da carne impondo verdades absolutas como caminho natural do desenvolvimento humano.

\subsection{0 - Uma pequena, mas monstruosa conclusão}

O monstro fascina pelo olhar, pela visão arrebatadora que sua figura exerce, pela superabundância e pelo excesso de presença. Se considerarmos a junção de duas ou mais espécies veremos os mesmos excessos. O Minotauro, meio homem meio touro; não é nem um corpo humano sem cabeça que possui uma cabeça de touro, nem uma cabeça de touro sem corpo enxertado num corpo de homem. Pelo olhar os seres se mostram, deixam-se habitar, "na medida em que também a vejo, elas permanecem moradas abertas ao meu olhar e, situado virtualmente nelas, percebo sob diferentes ângulos o objeto central da minha visão atual. Assim cada objeto é o espelho de todos os outros". (MERLEAU-PONTY 1999, pág.105). Duplicidade projetada para inferir ao espectador que o excesso que ele vê é o que está em excesso em todos nós.

Desta forma, corpo e meio ambiente se interpenetram constantemente, numa troca contínua de mão-dupla, onde as mais variadas percepções são geradas. O conceito de Unwelt (mundo ao redor) criada pelo biólogo e filósofo Jakob von Uexküll (18641944) ressalta que toda realidade é um fenômeno subjetivo. Cada sujeito tem diferentes visões/percepções e que estes sistemas têm como ambiente o mundo. A mesma realidade, no entanto, cada um irá perceber de maneira diferente, portanto subjetiva. Um dos exemplos clássicos é o "ambiente do carvalho", onde Uexküll relata que esta árvore habitada por diversos animais e integrada também ao ambiente do homem, proporciona diferenciadas experiências e percepções do carvalho. Que nestes inúmeros ambientes com diversos habitantes, o carvalho, enquanto objeto, desempenha papéis completamente variados e diferentes: ora assustador, ora protetor, ora econômico, ora 
grande, ora pequeno, enfim multifacetado. Em cada ambiente, cada sujeito realiza um recorte da realidade, conecta-se com as propriedades importantes para sua existência. Para Uexküll, o Unwelt é composto de sistemas abertos à espera de um ambiente favorável para se abrir, agir e se reproduzir. Uma conotação histórica evolutiva de interação. Segundo ele, as espécies exploram a relação espaço e tempo tendo uma interação que varia de espécie para espécie em função de exigências do próprio ambiente.

O monstro vira a pele do avesso, a expõe e a desonra. Mostra que o interior do corpo é feito de carne e osso e ao corporificar este interior subverte a ordem mais sagrada das relações entre alma e corpo. "A alma revelada deixa de ser uma alma, torna-se no sentido próprio, o reverso do corpo, um outro corpo, mas amorfo e horrível, um não-corpo. Que monstruosidade carrega o monstro teratológico com ele? A de uma alma feita de carne, vísceras e órgãos" (GIL, 2008, pág.79). O corpo teratológico provoca a vertigem da irreversibilidade. Na figura do monstro podem-se exteriorizar as fantasias, para mais tarde (ou não) através da catarse livrar-se delas, parcial ou totalmente. É a busca de si mesmo, a maneira de ver o que não se vê habitualmente, o que não se gostaria de ver e neste devir conjugam-se angústia e desejo.

E neste constante devir os monstros inserem-se na lei do eterno retorno. Nas sociedades arcaicas havia a necessidade de regeneração periodicamente, através dos rituais por intermédio da repetição de um ato arquetípico. A vida do homem arcaico, baseada na incessante representação dos mitos essenciais, apesar de acontecer no tempo não carrega o peso do tempo, não registra sua irreversibilidade. Vivia num presente contínuo, mimetizando geração após geração os gestos que lhe foram ensinados, perpetrando através da repetição um presente atemporal. Um exemplo clássico para ELIADE (2002) é a crença relativa à lua, revelando uma busca pelo eterno retorno. Em suas fases - aparecimento, aumento, diminuição, desaparecimento e seguido novamente da mesma sequência mostra que o ritmo lunar revela a estrutura cíclica do tempo, que é regenerado a cada novo "nascimento". E para se garantir a durabilidade de uma ideia ou norma de uma suposta verdade absoluta, certas cosmogonias sempre associaram a criação do mundo através do sacrifício de um monstro primordial o que concebia a desmobilização do caos. Nada pode durar se não for "animado" se não tiver uma alma. 
Para Nietzsche, todas as coisas do mundo estão inevitavelmente articuladas na infinidade do tempo, onde tais forças se combinam até que se esgotem todas as possibilidades e ao final deste embate retomam as combinações já pré-estabelecidas. Tudo liga-se num perpétuo jogo de elos interligados. No mundo algo não se torna; passa; vivendo de si mesmo: "suas dejeções são seus próprios alimentos". (NIETZSCHE. 2011, pág. 136).

Contudo, Deleuze aponta que o que retorna não é o mesmo, não é o mesmo ciclo, e sim, o diferente, por meio da repetição, onde o eterno retorno não tem como princípio a identidade, mas a vontade de potência ${ }^{17}$. O monstro é a diferença na repetição. Na repetição do monstro há a transgressão, a exceção por natureza, “[...] manifestando sempre uma singularidade contra os particulares submetidos à lei, um universal contra as generalidades que estabelecem a lei” (DELEUZE, 1988, pág.26). Mas ele (o monstro) distingue-se no que não pode se distinguir: o homem. É uma luta contra um adversário que se opõe a algo que não se pode distinguir. Como o relâmpago difere do céu negro de onde se origina, mas ele o acompanha, é imanente à sua origem.

O sono da razão engendra monstros, possibilitando ao que está no fundo suba, adquirindo uma existência autônoma; quando a forma sobe a superfície, o rosto humano se decompõe, deforma-se num espelho que determina a diferença. "Uma receita barata para se produzir um monstro é amontoar determinações heteróclitas ou sobredeterminar o animal" (pág.64). O pensamento estabelece a diferença e o que é diferente a priori nos parece maldito, seja no pecado ou na figura do mal condenado à expiação. O único pecado é emergir do fundo em forma dissoluta, calcada na relação essencial entre o determinado e o indeterminado, entre o claro e o escuro. Quando a representação encontra em si o infinito apresenta-se como uma representação orgíaca e não mais orgânica. Ela reencontra o monstro na diferença, pois a introdução do conceito do disforme ao infinito reporta-se ao fundamento. Seja para o bem, que age como princípio de escolha e de jogo, seja um fundamento negativo, atuando como dor. Em suma, o monstro é uma representação orgíaca que guarda a forma como princípio. O ser unívoco (homem) reporta-se as diferentes individualidades (monstro). Ou seja, uma cor tem várias tonalidades, mas permanece a mesma cor em essência.

\footnotetext{
${ }^{17}$ Falaremos sobre vontade de potência no capítulo 2 quando mostramos que as máscaras guardam a vontade de potência divina.
} 
O monstro insere-se no eterno retorno pois nele pensamos o mesmo a partir do diferente. Só as formas extremas que se desenvolvem no limite retornam e vão até o extremo da potência. Só retorna o excessivo que no outro se torna idêntico. "Eis por que o eterno retorno se diz somente do mundo teatral das metamorfoses e das máscaras da vontade de potência[...]" (DELEUZE, 1988, pág.84). O monstro de forma destoante e universal tem um papel fundamental na psique humana. Se o monstro aparece em todas as civilizações, em qualquer época, relacionado seja com indivíduos "normais" quanto em doentes mentais é porque ele realmente habita a natureza humana. Porque o medo sempre foi um poderoso agente pelo qual o poder vigente exerce sua força de coerção moral, política, social e econômica. O político se preocupa, antes de tudo, em negar tudo que gera diferença para conservar a ordem estabelecida.

Entretanto, o monstro também é o guardião do tesouro, simboliza os obstáculos que exigem superação, é quem incita o heroísmo através do medo e através de seus enigmas desvenda-se o desconhecido, ao mesmo tempo em que coloca à prova nossas capacidades e nossos méritos. Devora internamente o homem num rito de passagem cíclico. Sinal de sagrado e profano, todas as riquezas, conhecimentos, as salvações e a imortalidade passam por ele, deve-se atravessá-lo para transgredir, transmutar ou transcodificar o invisível: regeneração representada de um novo homem. Como também suscita as forças irracionais bíblicas, a imaginação contra o caos e a desordem, algum desejo pervertido, perfeita imagem da angústia e do medo, estado convulsivo de atitudes diametralmente opostas: o bem e o mal. Forma de expressão compartilhada, dentre inúmeras versões por vezes contraditórias. De caráter ambíguo, duplo. É o espelho da carne, é a diferença no olhar, produto político de contenção; social de catarse e econômico por diversão. Excede-se em sua imagem como elemento gerador de sentidos para que pensemos sobre nossa própria humanidade. È também na pluralidade de sentidos e formas, aliados à tecnologia, que o território da arte se expande, fazenco com que a vida adquira uma experiência profunda de polissemia.

Tais experiências revelam um novo monstro no horizonte, e leia-se monstro tudo aquilo pelo qual não se pode ser julgado com clareza, mas exposto numa dimensão que gera discussões sobre qual o próximo passo, para onde convergimos, quais as implicações do controle social e do ufanismo híbrido. Otávio Donasci e Denis Marleau criam seus próprios seres, atualizam o mutante emergente dentro da contemporaneidade. Dão a luz ao que as inteligências teóricas, durante dois milênios, tornaram possível ao 
se reproduzirem nos organismos projetados pela sociedade tecnológica. Conforme HANNA (1972) a filosofia e a ciência guiam, interpretam e ajudam no parto doloroso, desta nova forma de coexistência híbrida, destes novos monstros que se avizinham e que tornam ainda mais as percepções do corpo em possíveis construções transumanas.

Os monstros de Donasci/Marleau nos proporcionam uma percepção analítica do mundo, que Merleau-Ponty e os psicólogos da Gestalt observam como inquiridora, atenta, que ajustam nossos controles somáticos, de maneira que nossas experiências possam conceber uma forma. Ou seja, ao procurarmos por algo, direcionamos nossa atenção e arrumamos nossas "antenas" de modo que nossa percepção esteja condicionada a focalizar uma forma, uma entidade, uma figura dentre muitas outras. Desta forma, seus monstros denunciam o homem como produto de um modo de pensar configurado pelos sistemas de controle, como uma maneira pré-concebida de perceber o mundo. Possibilitam a descoberta e isolamento desta figura para que possamos refletir sobre os caminhos, as possibilidades que o excesso ou ausência, tão peculiares ao monstro, são realmente necessários a esta nova configuração que espreitamos em pleno século XXI. Ao mesmo tempo, expõem como os organismos adaptam-se ao ambiente, deixando claro que as instituições sociais, políticas e religiosas tem como fundamento a reunião eficiente dos homens e suas consciências moldadas pela moral da comunidade.

O novo monstro é um ser da técnica, diferentemente do Renascimento até o século XIX, quando as artes eram artesanais. A técnica é um saber fazer, que caracteriza habilidades que são introjetadas por um indivíduo, entretanto a tecnologia também é uma técnica, mas a transcende. O monstro videográfico subjetiva a transformação do ser, a inevitabilidade diante de um outro mundo, da simbiose do orgânico com o inorgânico. Um mundo animado por carne e pixels, onde o espectador atualiza o real na presença ou na ausência do ator e nos incita a julgarmos criticamente o que está detrás desta máscara. 


\section{A MÁSCARA}

“[...] é o rosto perturbado e perturbador do desconhecido, é o sorriso da mentira, é a própria alma da perversidade que sabe corromper à medida que aterroriza, é a mordaz luxúria do medo, é a angustiante e silenciosa eventualidade deste desafio lançado à curiosidade dos sentidos: "Será feia? Será bonita? Será jovem? Será velha?". É a galanteria temperada de macabro e de picante, e quem sabe, condimentada com uma pitada de ignomínia e um gostinho de sangue. Mas onde é que vai acabar a aventura? [...]"

Jean Lorrain, Histoire des masques.

"Uma máscara pode servir para mascarar outra".

Max Ernst.

\section{CAPÍTULO 2}

\section{ESCONDER PARA REVELAR}




\section{1 - Palimpsestos corporais. A Máscara e seus conceitos}

Se o ser humano ao longo de sua existência adaptou-se para poder sobreviver, a máscara trilhou um caminho semelhante ao se reinventar até hoje. As antigas sociedades utilizavam a máscara como um veículo de comunicação entre o mundo natural e o sobrenatural. Seu portador, através de uma cerimônia, concilia-se com as forças do bem, vence os demônios, capta energias de um outro mundo, possibilita a transformação animalesca, representa um deus e mimetiza as forças da natureza. Animar uma máscara sagrada é ir além do irracional, é proporcionar à comunidade mutar o ambiente em que se insere. Mascarar-se é tornar-se outro, é a forma como as sociedades antigas dialogavam com o sagrado, e a partir deste conceito introjetavam no pensamento coletivo e individual, as normas, as mudanças, fomentando a passagem do real ao imaginário - e vice-versa - através do rito.

Quem contempla a máscara é submetido a uma torrente de concepções só por ela conhecida. Transmutação coletiva jamais dissociada de coreografia, figurino, dança e música, a máscara proporciona ao seu portador ser "animado" pelo espírito dotado de uma energia superior a sua. O mascarado permanece imóvel, baila, salta, agita-se, seus pés golpeiam cada vez mais forte o chão captando as energias telúricas. Destarte, encarna temporariamente as forças assustadoras, imita-as, identifica-se com elas e figura como o verdadeiro laço social.

De madeira, papel, pano, metal, marfim, couro e dos mais diversificados materiais, a máscara suprime o rosto, criando um paradoxo do "esconder para revelar", onde a energia sintonizada naquele estado de presença confere vida aos corpos extracotidianos, suscitando através deste processo um elo de comunicação entre duas realidades: (visível e invisível) ao mesmo tempo que se caracteriza como polo de catarse coletiva. 


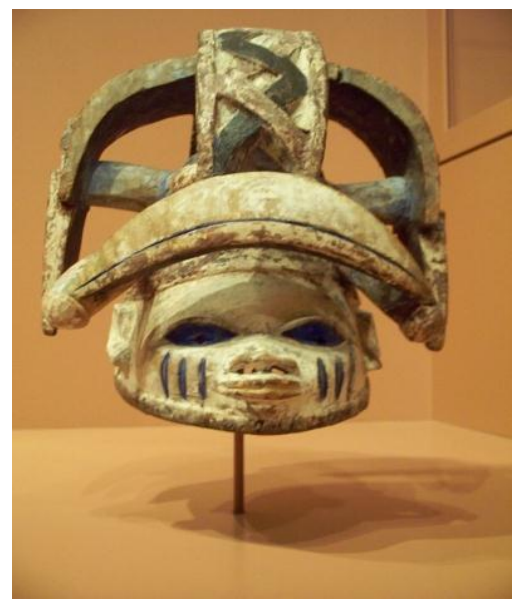

Figura 17 - Máscara de madeira Gelede

Yoruba (1930-1960) - Indianapolis Museum of Art.

Como "médium" traz consigo a imanente questão do simbólico, conjura o invisível em visível através de experiências físicas e emocionais. $\mathrm{O}$ ato de transmutar presente tanto na religião como na arte, é se permitir entrar noutra dimensão por meio da despersonalização, do disfarce. Uma ideia animista pela qual se toma conhecimento das coisas através do domínio dos mitos de origem. Ao se reproduzir uma figura animal ou antepassado, a máscara centraliza poderes entre dois mundos: o real e o sobrenatural.

Ao operar entre estes mundos, suscita fenômenos mágicos de uma realidade alterada ou expandida. Por intermédio da magia acontece a interlocução entre estas duas diferentes realidades, pelas quais FRAZER (1982) pontua dois princípios com os quais a magia ocupa-se. Pelo princípio de similaridade, simpatia ou afinidade, semelhante atrai semelhante, onde através da mimesis o fato a ser imitado se reproduz. Aspectos do sobrenatural são executados para que, através de sua reprodução se manifestem perante aos olhos dos espectadores. A ação mais conhecida deste tipo de magia, feita por muitos povos e em muitas épocas, está no ato de ferir ou destruir um inimigo danificando ou destruindo sua imagem. Neste pensamento se a imagem (simulacro) perecer o homem também perecerá. Pelo princípio da contiguidade (contágio), pessoa ou objeto que tiveram contato físico entre si conectam-se um ao outro, trocam energias. Fundamentase na crença de que algo ou alguém que teve uma ligação, por um breve momento, deve sempre conservar uma relação de simpatia, de modo que se um for afetado o outro também será. $\mathrm{O}$ exemplo mais notório deste tipo de magia de contágio é a clássica 
utilização de cabelos ou unhas, ou mesmo artefatos em rituais mágicos, em que a pessoa da posse de tais objetos exerce influência a qualquer distância sobre a sua vítima.

A máscara cênica ainda guarda esta essência ritualística-mágica tanto da similaridade quanto do contágio. $\mathrm{O}$ ator mascarado, ao compor a personagem, baseia a sua movimentação gestual pela forma, linhas, ondulações e características da máscara que animará. Assim, o corpo do ator tende a se aproximar do formato da máscara, buscando similitude entre corpo e forma. Lembrando que toda a regra gera uma exceção e compor uma gramática corporal diferente (contra-máscara) da máscara confeccionada é totalmente possível (e desafiadoramente muito interessante). Pelo princípio do contágio, ao ser iniciado nesta arte, o ator é submetido a uma série de regras e introjeta, muitas vezes sem questionar, alguns procedimentos para sua utilização. $\mathrm{O}$ ator incide sobre a máscara delicadamente seus dedos ao colocá-la e ao tirá-la do rosto, deposita-a sobre a mesa como se fosse o mais raro dos objetos, jamais colocando-a com a face voltada para a mesa, o que seria um grande sacrilégio, como também jamais tocar a máscara de seu parceiro em cena. E de contágio em contágio o ator passa a respeitá-la como um objeto ainda de extraordinário poder. Mascarar-se é objetivar uma crença, afirmar uma ideia ao mesmo tempo em que também há espaço para a transmutação. Assim, nas sociedades antigas a situação de cada povo - dominante/dominado - o ritual primitivo reforça a mensagem cultural ou política através das cerimônias-espetáculos com máscaras, bonecos ou sombras. Muitos povos reafirmam seu domínio sobre os outros, transmitindo sua religião, promovendo o conhecimento de seus heróis, ditando normas morais ou educando conforme sua conveniência e conceito da cultura popular.

A forma como são reforçadas essas crenças conforme CALLOIS (1990) é por meio da aceitação temporária de uma ilusão através do jogo, que se realiza na encarnação de um personagem ilusório e na adoção do respectivo comportamento. Ou seja, o indivíduo tem como característica comum de fazer crer a si mesmo ou ao outros que é realmente outra pessoa, que já não é o mesmo ao portar a máscara. Esquece, disfarça, despoja-se temporariamente da sua personalidade para ser outra pessoa. Esta forma de jogo denomina-se mimicry, que inglês refere-se ao mimetismo, como ao dos insetos, com a intenção de mudar a aparência e meter medo num possível inimigo. A mimicry é uma invenção recorrente com todas as características do jogo: liberdade, convenção, suspensão do real e espaço tempo delimitados. A máscara convida o espectador, durante um certo período de tempo, acreditar numa suprarrealidade. 


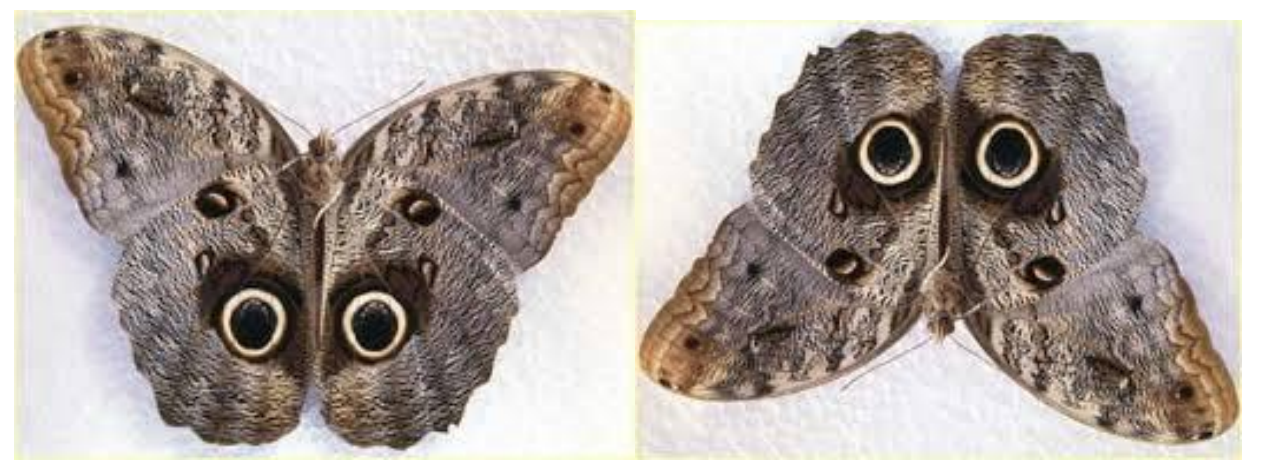

Figura 18 - Caligo memnon - Borboleta do gênero Caligo encontrada desde o México até a Floresta Amazônica.

O jogo é definido como uma atividade livre e voluntária, fonte de enlevo e diversão. Mesmo porque se fossemos obrigados a participar, seria coerção, uma obrigação, que rapidamente repudiaríamos. O que perderia a condição fundamental de jogo, que seria o fato de o jogador entregar-se espontaneamente à atividade proposta. Ele não tem outro sentido enquanto jogo e é por isso que suas regras são imperiosas e absolutas, transcendendo qualquer discussão.

Portar uma máscara é ocupar-se isoladamente da realidade, em geral dentro de espaço e tempo. É desfazer-se temporariamente das intricadas e confusas leis da vida cotidiana e durante um tempo transpor regras irrecusáveis, arbitrárias e aceitas como tais para um potencialização do jogo mascarado. É buscar o lúdico e colocar-se em situações constantes de risco, onde o ator ao jogar constrói em seu corpo um estado orgânico, onde brincar transforma-se em arte. O jogo depende do movimento, do gesto e ao mudar de rosto automaticamente muda o corpo, o que acarreta entrar num jogo maior que o do dia-a-dia, para além do cotidiano.

A máscara como símbolo é uma ideia que se propaga, que se manifesta no sensível através da forma. $\mathrm{Na}$ imagem figurada se vê o todo num só momento. A imagem divina, na representação figurada de um deus está na forma plástica pela qual a imagem é transmitida. Uma imagem concreta, concisa, delimitada, permite que o simbolismo do deus projetado intensifique-se pelo olhar, monopolizando o invisível em visível. É interessante perceber que o símbolo religioso, onde a máscara atua como polo mediador atua numa realidade que se preocupa menos em representar e se ater mais em manifestar, efetivar a energia no mundo visível. "O símbolo religioso implica a 
presença em si do referente, posto como potência[...], um poder que se exerce num domínio definido" (VERNANT, 1991, pág. 18). O referencial da máscara fica excluído do domínio da linguagem ao qual não pertence pois está na "natureza". Seu simbolismo religioso fundamenta-se mais que uma linguagem humana, de significado e significante. É a força divina que se comunica com os homens através dos símbolos, onde o real é captado sob forma de força ou de ordem. FELÍCIO (1989) pondera que o ator é mais inclinado a não pensar no espectador e no sentido da ação, elaborando seus gestos a partir de seu figurino e de sua máscara, o que lhe confere presença simbólica em cena.

A máscara promove também um esvaziamento da interioridade, o ator cria sua imagem de modo que a significação da personagem para o público está nas situações que seu gestual define. Entregar-se é a melhor forma de a conhecer, contudo não permite que você seja você mesmo atrás/através dela. A máscara exige um esmaecimento temporário da personalidade, mas não a ponto da alienação. $\mathrm{O}$ ator não suprime por inteiro sua personalidade, mas trabalha com uma justaposição.

Em sua tese de pós-doutorado, A Outra Face: A Máscara e a (Trans)formação do ator, Felisberto Sabino da Costa propõe de forma poética um pequeno órganon ${ }^{18}$ para a máscara e como ele mesmo afirma, este texto-máscara, um palimpsesto, que cada um pode usar como melhor desejar. Vestir e (re)vestir como assim o desejar. O ato de mascarar-se não é uma ciência exata e alguns de seus tópicos exemplificam pontos importantes que aparecem nas monstro-máscaras de Donasci/Marleau.

Espaço-tempo de alteridade[...] (des)veste, (re)veste, (trans)veste. A máscara fascina porque traz em si vida e morte[...].

A máscara não é o território do absoluto[...]. Invasora de um corpo que é invadida por outro.

Potencial de algo que será criado. Um outro que irá surgir. Devir. Espaço de multiplicidade e de virtualidade.

\footnotetext{
18 Órganon é o nome dado pelos comentadores gregos de Aristóteles ao conjunto de seus escritos sobre a lógica. Arcabouço lógico indispensável para uma demonstração filosófica ou científica.
} 
Lugar onde movimento e imobilidade se encontram[...]. A máscara é o entre-dois [...].

[...] Sintese que amplia os significados.

O mundo quântico é caracterizado pela ausência de permanência: há uma agitação perene incessante. A rigidez material familiar é uma ilusão causada pela nossa percepção macroscópica da realidade. O vazio está cheio de energia [...].

O outro lado do espelho [...] (Ultra)Passagem entre o real e imaginário[... $]^{19}$.

Em sua rigidez facial, a máscara representa sempre o geral, os tipos, nunca o particular. É um conglomerado de ideias e emoções que segundo AMARAL (1991), transcende a própria forma e revela uma realidade além do olhar, do indizível-invisível. O palco é um lugar onde o invisível pode aparecer e exercer grande influência imagética em nossos pensamentos. Se a maior parte da vida nos escapa aos sentidos, a repetição ritual que a máscara proporciona através de ritmos e formas, enfatiza os comportamentos, as multidões e os ideais. As máscaras manifestam no presente o que está por vir e exerce na potência sua vitalidade e longevidade. Como subjétil ${ }^{20}$, confere ao corpo a possibilidade de criação de gramáticas, estados e ações. Suporte e superfície para poesias extracotidianas.

\section{2 - As três potências sagradas da máscara.}

Denomina-se potência a capacidade de realizar mudança em si mesmo ou a outro, como também guarda a ambiguidade de predeterminação de resistir a qualquer mudança. Para BERGSON (2006), a potência é a "miragem do presente no passado", onde o porvir certamente tornar-se-á presente, com o efeito de miragem prolongando na imagem do amanhã. Neste ciclo é como se nos configurássemos diante de nossa imagem no espelho, onde a potência estaria o tempo todo, sempre, como um fantasma que espera sua hora para entrar em cena. De trás para frente o presente se remodela, da causa pelo efeito.

\footnotetext{
${ }^{19}$ SABINO, Felisberto. Tese de pós-doutorado - ECA -USP - 2006, pág. 158.

20 Subjétil é uma expressão de Artaud citada por Derrida em Enlouquecer o subjetil e está relacionado com o trabalho do ator entre sujeito e objeto, como encontrar novos territórios não subjetivos, onde as coisas o atravessam.
} 
Onde há vida, existe vontade de potência e estamos propensos a um eterno esforço contra o niilismo. Não se trata apenas de um instinto de sobrevivência, de preservação da vida, mas um ir além, um constante vir a ser, o estado instintivo mais forte que governa a evolução orgânica. Vontade de potência, como afirma Nietzsche, é a luta permanente entre dois impulsos: um para mais; outro para menos. O de mais é um impulso de vida, de potência. Em contrapartida, há o impulso de menos, um impulso de morte, de passividade, de degeneração, de aniquilação. Na vontade de potência busca-se também a contradição; o que é feio quer tornar-se belo, ou ainda, o escravo deseja tornar-se senhor. "A vontade de acumular forças é inerente ao fenômeno da vida: nutrição, procriação, hereditariedade para a sociedade, Estado, costumes, autoridade [...]. Ao mesmo tempo que invisto em minha própria sobrevivência, posso também ir além, ao transcender dedico-me ao desejo de apropriação, de tornar senhor" (NIETZSCHE, 2011, pág.105).

Esta vontade de potência é uma força criadora, plástica, é o impulso que toda força se efetiva, criando desta forma novas configurações. Nietzsche afirma que o mundo é múltiplo e a multiplicidade de forças estão constantemente em combate umas com as outras.

A máscara absorve a personalidade do ator e dela se alimenta. Acende seus sentimentos e esfria a sua cabeça. Permite ao ator vivenciar, de forma muito virulenta, a química da atuação: no exato momento em que os sentimentos do ator estão no seu ápice, por trás da máscara, a urgente necessidade de controlar as suas ações físicas obriga-o a ter desapego e lucidez. (SAINT DENIS, apud JOHNSTONE, 2003, pág. 199).

A máscara cênica até hoje conserva tais potências divinas. Em primeiro lugar a potência que opera através da máscara que não tem outra configuração a não ser a própria máscara é a Górgona. Outra divindade sem ser por si máscara, mas que carrega consigo o seu fundamento e que concebe ao seu portador um papel distinto é o de Ártemis e por último, a potência com maior intimidade com a máscara, em todos os planos, caracterizando-se como o deus-máscara é Dionísio. 


\subsection{1 - GÓRGONA}

Sua representação pictórica na arte grega arcaica, em vasos, na frente de templos em acrotérios ${ }^{21}$ e antefixos, como também nos escudos dos soldados, tem como conceito principal a frontalidade. Sua imagem, sem exceção, sempre está de frente ao espectador que a contempla. Pura máscara ou personagem inteiro, sua figura serve como interferência entre o humano e o bestial. Sua multiplicidade de formas através de sua cabeça larga e arredondada, o que lembra a fronte leonina, com os olhos enrugados, fixos e penetrantes, sua cabeleira de serpentes, orelhas deformadas, parecidas com a de um boi, promovem uma distorção que petrifica. Mirar frontalmente a Górgona é se perder em seu olhar, sem poder desviar a atenção. Neste processo realiza-se um efeito de desdobramento, onde através do jogo do fascínio que a máscara exerce, o indivíduo se vê retirado de si próprio, invadido por sua figura que o imobiliza, que apodera-se dele e o possui. Conforme VERNANT (1991) sua visão inquietante gera estranheza, um monstruoso que oscila entre dois polos: o temor angustiante e a gargalhada catártica. $\mathrm{O}$ masculino e o feminino, o jovem e o velho, o belo e o feio, o celeste e o infernal entram em simbiose, confundem-se e intercruzam-se.

\footnotetext{
"O rosto da Górgona é o Outro, o duplo de nós mesmos, o Estranho, em reciprocidade com a nossa figura como uma imagem no espelho seria ao mesmo tempo menos e mais do que nós próprios, simples reflexo e realidade do além, uma imagem que nos traga porque em vez de nos devolver simplesmente a aparência de nossa figura, de refratar o nosso olhar, representa, em seu esgar, o horror terrífico". (VERNANT, 1991, pág. 92).
}

A Górgona conduz quem a fita ao pavor em estado puro, porque se mostra em campo de batalha, retratada nos escudos, como um prodígio, uma face-monstro (pélor) que é mimeticamente reproduzida pelo rosto do guerreiro em seu furor. O olhar da Górgona associado com frenesi facial e petrificado do combatente irradia a morte e

\footnotetext{
${ }^{21} \mathrm{O}$ acrotério, do grego, elemento mais elevado, é o recurso que serve como arremate ornamental para o ponto mais alto de um frontão. Templos antigos apresentam esse elemento em uma grande variedade de materiais: pedra ou terracota, por exemplo, dependendo do material de que é feita a cobertura
} 
através do vigor da batalha induzem ao transe furioso. A cólera do guerreiro transformase em máscara.

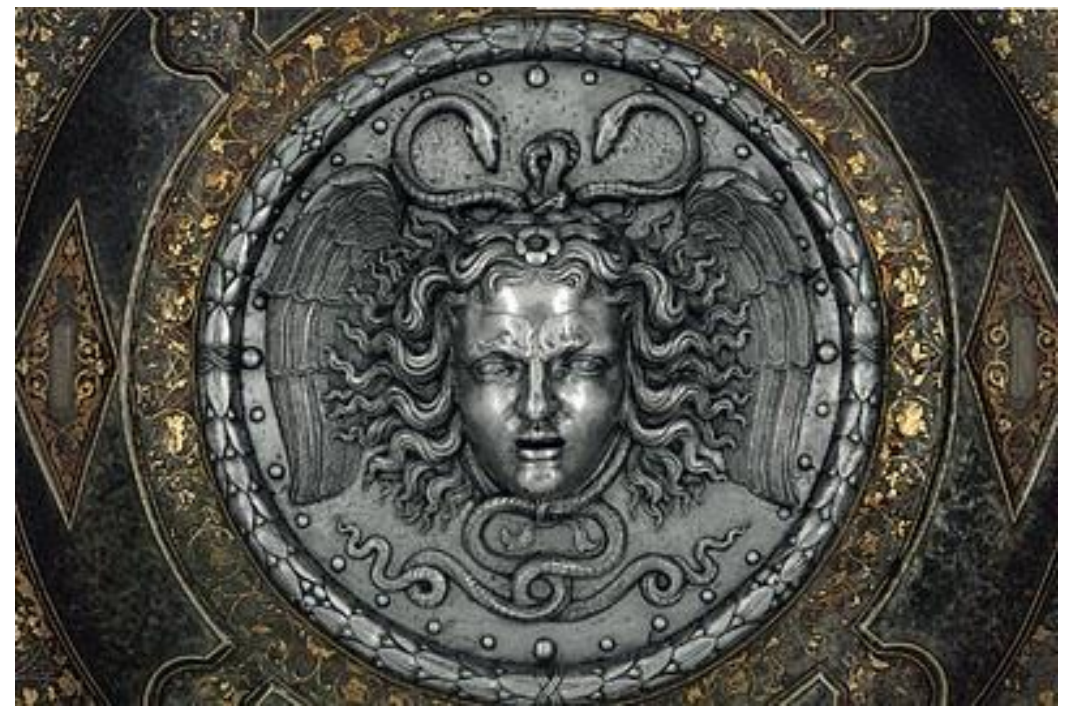

Figura 19 - Cabeça de Medusa que adorna escudo de Forma circular. Obra de Filippo y Francesco Negroli - 1541.

O transe é um dos principais mistérios que envolvem as práticas mascaradas. A correlação entre máscara e possessão potencializa-a como instrumento de controle. $\mathrm{O}$ portador "veste" a máscara, traja um figurino e começa a dançar ao som de uma batida rítmica sequencial, ininterrupta e excessivamente alta. Tais vibrações surtem efeito no corpo que parece adquirir cada vez mais energia até um estado de entorpecimento. Neste ato estabelece-se, consequentemente, uma aproximação, uma troca de identidade, que consiste em arrancar-se a si próprio e projetar-se numa alteridade efêmera no espaço, mas transformadora, no tempo. O grupo que a tudo assiste, cúmplice desta epilepsia e destas convulsões sagradas, fica absorto na irrupção destes fantasmas, espíritos manifestos através do transe e do frenesi. Encontram no rito a embriaguez de ter medo ou de meter medo, numa espantosa cumplicidade entre simulação e vertigem. Nesta desmesurada epifania energética que o possesso pela máscara exibe, há uma certa propensão de espalhar o pânico e a angústia. A máscara serve para inspirar terror aos profanos e, ao mesmo tempo, para esconder a identidade do convertido. Impõe ferocidade ou graça quando o portador através da simbiose converte a máscara em seres 
vivos, onde os mortos são chamados à vida pelo ato simbólico da representação de forças etéreas.

\subsection{2 - ÁRTEMIS}

A potência de Ártemis é um conceito ampliado da máscara e está ligada diretamente ao rito. O indivíduo realiza uma série de gestos, que ao serem executados tem como finalidade unir vontades, orientar ações, harmonizar as almas e atingir um equilíbrio geral de forças. Todos estes gestos são pautados na necessidade de coerência social. Podemos ter um exemplo claro de tais ritos em nossas ações do cotidiano, como exemplifica BENOIST (1977), quando retirarmos o chapéu por respeito, quando inclinamos a cabeça em deferência a algo ou alguém, ou mesmo ao estendermos a mão em cortesia, estamos repetindo antigos ritos sagrados, hoje profanos, uma miscelânea de símbolos transformados em hábito. O rito delimita um círculo sagrado, reservado, que sacraliza o ato para celebrar as potências invisíveis, das quais esperamos em retribuição, ajuda na transformação ou proteção.

A deusa Ártemis é a virgem caçadora, a arqueira que atinge com suas flechas todos os animais selvagens, cujo ressentimento é evitado a todo custo devido a sua vingança impiedosa. Prelúdio de querela e massacre, Ártemis não encarna precisamente a selvageria em estado puro, ela atua nos confins entre o selvagem e o civilizado, intervindo nestes dois mundos, na vida individual e social. Não é representada por uma máscara, mas em forma de escultura, de um ídolo arcaico, de madeira, de aparência rude que os gregos chamavam de xoanón ${ }^{22}$. Olhar tal ídolo, muitas vezes é se entregar ao delírio, a loucura.

A função de Àrtemis é encarregar-se do crescimento dos jovens (homens e mulheres) até a maturidade. Cabe a ela a transmutação de um estado a outro, através da potência que perpetua a vida, para que o grupo se desenvolva dentro das normas previstas. Padroeira dos jovens, o ritual a Ártemis prepara a nova geração de adolescentes para integrar e ocupar o seu lugar no mundo, onde serão inseridos nele sem perturbá-lo. Esta

\footnotetext{
22 “xóanon", ídolos de madeira, mais ou menos aplainada, com forma também de pilastra, que é adorada, comporta algo de divino, sobrenatural, possuindo assim uma vida ritual.
} 
passagem serve de treino para que o jovem aprenda a tornar-se adulto abandonando comportamentos aberrantes, desviados e até delirantes.

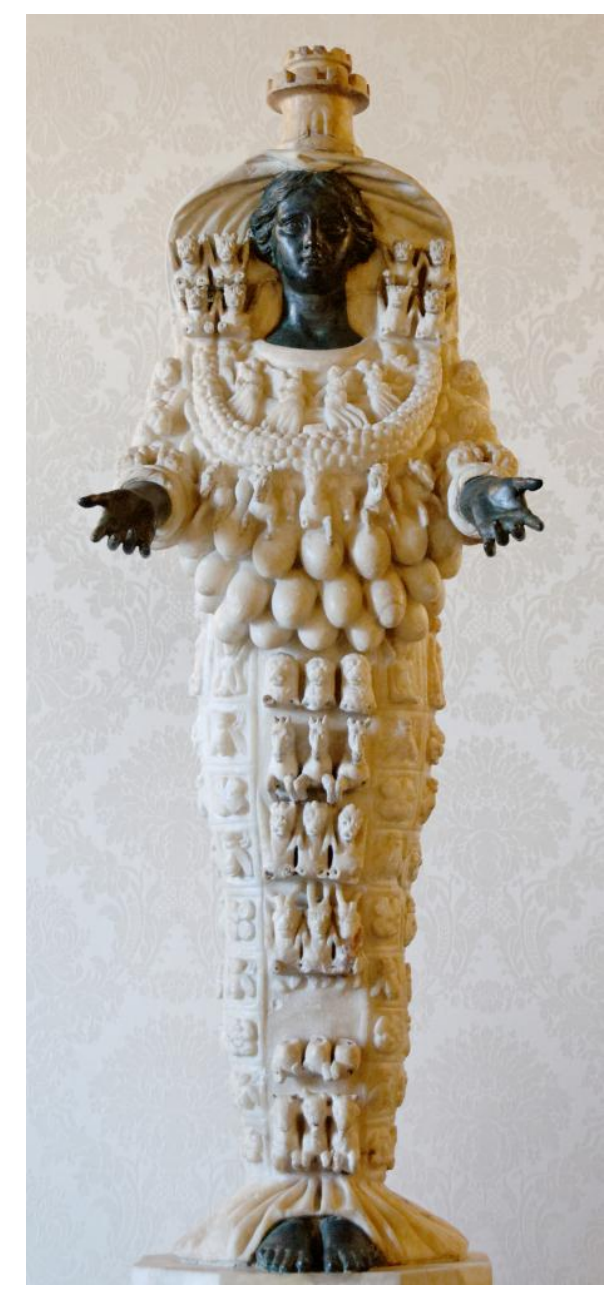

Figura 20 - Artemis de Éfeso - Museu Capitolino, Roma.

Sendo assim, tornar-se adulto é renunciar-se a si, abandonar a deusa, morrer simbolicamente para o estado anterior e assumir novas funções e percepções de um novo estágio da vida. A potência de Ártemis opera entre o selvagem e o civilizado, entre a ordem e o caos. O furor e o pânico produzem efeitos análogos ao impulso cego, destrutivo. $\mathrm{O}$ homem que se entrega a fúria transgride os limites e torna-se cego para o divino. Invadido pela potência, possuído por um delírio, o transforma por dentro e o emancipa pelo devir na aquisição de um novo estado e o devir é a matéria do simulacro. “Os simulacros [...] fazem valer seus efeitos (o que poderíamos chamar de “fantasmas”). O mais encoberto tornou-se o mais manifesto, todos os velhos paradoxos do devir reaparecerão numa nova juventude - transmutação" (DELEUZE, 1974, 
pág.7). A passagem para alteridade o define como indivíduo e o assimila à norma comum.

A potência de Ártemis trabalha o conceito expandido da máscara, que atua consequentemente em nosso psiquismo, como as pranchas de Rorschach que analisam a vontade de dissimulação, através das interpretações dadas aos borrões. Estas máscaras virtuais (manchas) penetram na zona em que a ideação e a imagética permutam continuamente suas ações. A maioria das pessoas examinadas por tal método não extraem figuras, nem caricaturas, nem símbolos, mas reproduzem suas máscaras. De acordo com BACHELARD (1994) ela não é percebida, é profundamente sentida, o sujeito a reforma do mesmo modo que a forma e a cada reformulação acredita piamente que esta seja verdadeiramente sua máscara.

\subsection{3 - DIONÍSIO}

A par das estátuas antropomórficas comuns aos outros deuses, Dionísio, especificamente, dispõe de um tipo particular de representação: uma simples máscara de madeira ou de pedra. É o próprio deus-máscara, um rosto com que o espectador se defronta e que olha nos olhos. Como a Górgona, esta divindade tem uma relação de frontalidade, dualizada, simétrica, um olhar que fascina o homem, o possui.

Os rituais dionisíacos, o cômos, implica em música, dança, vinho e embriaguez, comportamentos excessivos e disformes, onde os homens afastam-se das normas dos comportamentos habituais através do trajar e da atitude. Era necessário abandonar a boa aparência e o completo domínio de si para se aproximar de Dionísio. Desta maneira, os homens transformam-se através de um gestual desordenado e passam a ser outrem. Deus essencialmente teatral, um símbolo da presença imediata que envolve o público.

Senhor da epifania, ri de todas as regras, da ordem, "riso que precede, paradoxalmente, o silêncio da morte" (FELÍCIO, 1989, pág. 17). Esta torrente furiosa de caos faz tudo que estava fechado abrir-se, alterando as próprias dimensões habituais de tempo e espaço. Não há como compreender o deus-máscara senão entrar no seu jogo, porque Dionísio dispõe e submete seus fiéis a uma força irracional, é alheio as nossas 
normas, nossos costumes, as nossas indagações, para além do bem e do mal, está apenas interessado em fazer surgir em nós: o outro.

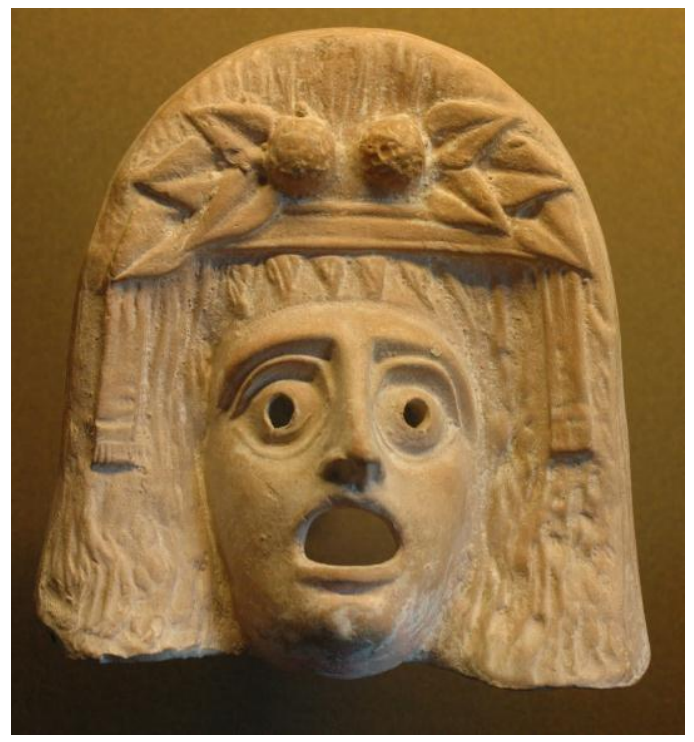

Figura 21 - Máscara de Dionísio, Myrina, século II a.C.

Podemos correlacionar à potência de Dionísio com relação ao espelho, ou seja, um distanciamento de si mesmo. Olhar-se frente a frente é confrontar nossa dualidade. No mito de Narciso, ele se vê como outro. O espelho é o meio de alguém se conhecer, de se dividir, de dualidade do sujeito fora da realidade cotidiana, onde o elemento enigmático (o outro eu) se comporta com um ar misterioso na forma de sombra, de fantasma ou monstro. Por outro lado, ROSSET (1976) estabelece que o espelho é um enganador, a ilusão de uma visão, ao mostrar o inverso do "eu", do não-corpo, de uma superfície, um reflexo. A busca do eu, especialmente nas perturbações de desdobramento está sempre ligada ao retorno ao espelho. O duplo fabricado é apenas uma representação de sua unicidade.

Otto Rank em seu livro, O Duplo, afirma que o desdobramento de personalidade está relacionado com o medo ancestral da morte. Sendo assim, o duplo imaginado é um duplo imortal com a intenção de nos salvar da própria morte. Ou seja, o problema psicológico do desdobramento de personalidade não se encontra na mortalidade, mas na dúvida da existência: “quem sou eu?”, “o que pretendo ser?”. É uma segurança contra a 
destruição do ego, a duplicidade contra a extinção, como afirma Freud (1919) e tem sua contraparte na linguagem dos sonhos e no narcisismo primário que domina a mente da criança e do homem primitivo.

Como potência, encontramos tanto nas monstro-máscaras de Donasci quanto de Marleau o que os gregos chamavam de kolossós, um efeito desconcertante de presença na ausência, que opera no duplo e registra no vazio o próprio ser que ele evoca, através de um substituto (homem mascarado). Como também a psuché, que se manifesta em forma de aparição, fantasma de um corpo, um duplo que reproduz suas particularidades. Kolossós é consistente e denso, evoca-se o morto ou desaparecido no mundo das sombras, simulando sua aparência de outrora em uma pedra bruta. Já na psuché, a aparência do indivíduo é similar e constitui outra face da sua irrealidade, ou sobrenatureza. Tanto a psuché, quanto o eídolon ${ }^{23}$ não consistem o fantasma do morto após sua morte, e sim, o duplo do corpo desaparecido. O corpo então desmaterializa-se para tornar-se imagem vaga, irreal, transitória do que na verdade somos. A preocupação dos gregos com o duplo consistia em peça essencial para entender a presença-ausência.

Entende-se por presença uma relação espacial com o mundo e seus objetos e seu poder de impacto em corpos humanos. A produção de sentido refere-se ao ato de "trazer para diante" um objeto para o espaço e seu impacto sobre nós. Nas culturas de presença, como afirma GUMBRECHT (2004) os seres humanos acreditam que seus corpos fazem parte de uma cosmogonia, de uma criação divina, e neste tipo de cultura o conhecimento válido é o conhecimento revelado. A máscara por atuar entre os limites do natural e sobrenatural, materializa a presença e realiza o ato de desvelamento, e uma vez o ato consumado não pode ser desfeito. Cada cultura de presença opera com concepções diferenciadas, mas com uma similaridade, a união do significante puramente material com um significado (sentido) puramente espiritual. Cabe lembrar que uma produção de presença o significante puramente material deixa de ser objeto de atenção quando se identifica o seu sentido subjacente. Corpos cotidianos transformados em extracotidianos geram sentidos de estranhamento, geram a ilusão de algo divino em cena.

A máscara carrega consigo o sagrado como potência, ao mesmo tempo em que produz uma presença ao esconder a identidade de quem a porta, proporcionando um

\footnotetext{
${ }^{23}$ Do rego EIDOLON - Ídolo. Aspecto, imagem mental, fantasma, aparição”, também “imagem material, estátua", de EIDOS, "forma".
} 
caminho que exige maturidade e discernimento de quem a utiliza. Confere ao homem a quem a ela se submete uma "jornada" igual ao do monomito, descrito por Joseph Campbel nos doze passos do herói:

Passo 1. O homem apresenta-se em seu mundo, em seu cotidiano.

Passo 2. É convidado a portar a máscara e aventurar-se por um corpo diferente.

Passo 3 - As negações de estar mascarado aparecem, os "nãos" psicossomáticos surgem como fantasmas: "não posso", "não consigo", "não quero" estar atrás da máscara.

Passo 4 - Encontra um mentor, um professor, um mestre, que o aconselha a tomar uma decisão.

Passo 5 - Precisa atravessar o limiar, ingressar num outro mundo mediado pela máscara. Sua decisão é motivada por inúmeros fatores que o impelem a tomar esta decisão: desejo de transformação permanente, de ser simplesmente outro ou de disfarce.

Passo 6 - Nesta fase é testado. No mundo mascarado desenvolve sua história, fora do seu ambiente normal. Passa por obstáculos, recebe ajuda (esperada ou inesperada) de aliados externos e terá que enfrentar os inimigos internos (psicológicos).

Passo 7 - Aproxima-se do objetivo da transmutação, a tensão aumenta e as regras da máscara são colocadas à prova. Acertos e erros o impelem a prosseguir.

Passo 8 - Provação máxima. É o mascaramento, o espetáculo, estar no centro das ações, colocar à prova todo o aprendizado.

Passo 9 - É a conquista da recompensa. Passada a provação máxima, a sensação de dever cumprido. Um mundo imagético conquistado, cognição alcançada e corpo extracotidiano entendido.

Passo 10 - Caminho de volta. O momento pós-mascaramento, passagem para o mundo cotidiano.

Passo 11 - Ações avaliadas pelo mestre. Pelo sucesso da jornada torna-se um iniciado, um homem, que agora, transita entre dois mundos. 
Passo 12 - Retorna ao mundo de origem, revigorado, transmutado, já não é mais o mesmo.

A frontalidade, o transe, o conhecer a si mesmo, o poder de alteridade, a produção de presença, o simulacro, o jogo, o improviso, o duplo são conceitos-chave que exaltam a sacralidade que a máscara impõe e que perdura até hoje. Dos ritos religiosos à manifestação teatral, as máscaras são sonhos materializados em corpos transmutados que codificam suas ações em gestos, movimentos e ritmos. Corpos que tornam-se objetos de experimentação, livres de grilhões naturalistas que o tangem a um comportamento padronizado.

\section{3 - Século XX, o retorno da máscara}

\subsection{1 - A descoberta do corpo}

O início do século amplia as condições para o ressurgimento da máscara, restaurando e aprofundando questões sobre o corpo "animado". Nenhuma das noções causa, efeito, meio, fim, matéria, forma - bastam para pensar as relações do corpo com a vida total, sua influência sobre a vida pessoal ou a influência da vida pessoal sobre ele. "O corpo enigmático: parte do mundo, por certo, mas estranhamente oferecida, como seu habitat, a um desejo absoluto de aproximar-se do outro e de unir-se a ele também em seu corpo, animado e animante” (MERLEAU-PONTY, 1964, pág. 258). Neste processo aparece uma consequência inevitável, a obsessão do outro. Este outro aparece na forma de tormento, da inveja ou, pelo menos, de inquietude e comparece ante um olhar alheio e justifica-se diante dele, quando o corpo vira objeto de contemplação.

O século XX inventa teoricamente o corpo, que sofre mutações do olhar com a eliminação das distinções entre são e enfermo, corpo normal e anormal, do afrouxamento de coerções e disciplinas herdadas do passado, legitimando o prazer ao mesmo tempo que normatiza uma série de novos direitos biológicos e políticos. $\mathrm{O}$ conhecimento médico preventivo ganha força com sua utilização justificada pela necessidade de uma imediata volta ao trabalho. A crença popular nos antibióticos 
abrevia a recuperação e cabe ao médico enviar o mais rápido possível ao front, para escola, para a fábrica ou para o escritório.

O corpo também torna-se espetáculo através das grandes multidões esportivas que, aos poucos, conquista espaços de lazer urbano. A preocupação com o esporte coloca em confronto o imaginário do desenvolvimento e do progresso, com o prazer voyeurístico da desenvoltura de corpos observados, com a velocidade ou força que imprimem. E neste jogo de massas a comparação se revela evidente, como afirma VIGARELLO (2008) o esporte identifica-se com os atores: Sentimento "exacerbado" do público, o frio na barriga dos esportistas antes de cada partida ou evento, ou ainda, os conflitos latentes entre público e atletas, que poderiam inflamar-se ao menor incidente. A sociedade esportiva criou seus próprios modelos de espetáculo: a criação real ou imaginária de uma lenda, a construção de um espaço mítico, que gera uma fascinação muito especial, um imenso sonho social que identifica às massas a este ser todo particular. $\mathrm{O}$ esporte ajuda a crer, acreditar na perfeição social, de se chegar à vitória contando consigo mesmo. O corpo renasce e começa a ser modelado para as necessidades que adentram ao século.

Eclode assim um sexto sentido, a priopercepção que cria no observador fluxos de movimentos, de signos e imagens através de uma paisagem urbana dinâmica. A visão começa a exercer sobre o corpo uma subjetividade e esta maneira de enxergar a vida reorganiza as emoções. A ciência descobre que toda percepção - antes mesmo de ser consciente de uma sensação, de uma emoção - provoca descargas motoras, ligando mobilidade e percepção. Neste corpo moderno dialogam o sensível e o imaginário, com repertórios refinados que dão origem a uma multiplicidade de corpos poéticos.

Paralelamente o corpo adquire uma nova visibilidade com a influência da arte primitiva africana, pela assimilação dos ideiais dadaístas, cubistas e futuristas, como também, pelos contatos com o Teatro Nô do Japão, de Bali, de Java, como também pelo nascimento do cinema. Nos palcos ou nas telas a corporeidade explorada suscita as experimentações sedutoras e condizentes com a evolução tecnológica da época.

Rudolf Laban (1879-1958) já demonstra em suas observações como o corpo deveria desenvolver um "saber-sentir" atrelado aos fluxos da vida moderna e de suas 
vibrações. Para ele, o bailarino, como também o ator ou o mímico deveriam afinar suas percepções concomitantemente com as tecnologias da era industrial. Das montanhas russas, passando pelo filme ou pela fotografia, seus corpos criariam experiências com rupturas espaço-temporais, através de solavancos, acelerações que induziriam coordenações cinestésicas e novas modalidades de comportamento. Para Laban a corporeidade do homem moderno é um palimpsesto, está ligado proprioceptivamente a cada época, década ou século. As expressões materiais de uma civilização - sua arquitetura, seus objetos, tecnologias conferem a cada indivíduo, desde a primeira infância uma assinatura corporal, uma configuração cinemática de seus gestos que caracterizam cada época.

Com Isadora Duncan o torso da bailarina adquire ressonâncias afetivas. As primeiras gerações de bailarinos, herdam a ideia de um centro fisiológico e emocional do movimento que irá desempenhar um papel primordial na dança moderna. Da mesma forma que a amplitude e a velocidade de movimentos "são efeitos da potência dinâmica do fôlego que se revela no grau de intensidade e de tensão do momento" (SUQUET, apud De MILLE, 2008, pág.519). É a tomada de consciência do corpo como espaço que contrai e se estira, produzindo a relação de encadeamento entre o espaço interior e exterior.

Com o advento do cinema, a construção das expressões corporais se transforma, pois tal representação oferece um novo horizonte imaginário como fonte do espetáculo de massa. Registrar imagens corporais e contar histórias resultam numa variedade de corpos estranhos, assustadores, impressionantes, magníficos, perversos e cheios de esperança. No cinema primitivo para atrair o público devia-se apresentar corpos excessivos e por este motivo, os filmes eram de monstros, sobre grandes criminosos e suas vítimas, pornográficos ou imagens de atletas. Desde as primeiras projeções, o laço entre imagem e fantasia se estabelece. "O cinema captura a imagem de corpos que deixarão de existir, um jazigo eletrônico de fantasmas, sensação percebida pelos primeiros espectadores” (BAECQUE, 2008, pág.484).

A evidência do corpo torna-se a emergência e contato com o mundo, ponto de interações permanentes entre o cultural e o social, tanto na prática como na representação. Através dele que toda a sociedade reflete ou simboliza seus ideiais e como cita BAUDRILLARD (1976), o modo de organização da relação do corpo reflete 
o modo de organização da relação com as coisas e o das relações sociais. Sendo assim, a técnica, os comportamentos aprendidos ou simplesmente transmitidos direcionam sinergias constituindo verdadeiros sistemas de um aparato sociológico. $\mathrm{O}$ andar, o jeito de correr, a forma do repouso ou do sono, passando pelas atividades profissionais, de gestos repetitivos e dispostos em determinado espaço/tempo conferem ao corpo a mecanização, a fabricação de corpos. A máscara é um objeto de desestruturação, de caos criativo, instrumento de fragmentação de atitudes sedimentadas que seu portador viabiliza. Ao mesmo tempo em que a técnica produz eficácia do gesto produtivo (taylorismo $^{24}$ e fordismo ${ }^{25}$ ), também através da máscara fomenta liberdade corporal, confere criatividade e potencialidade diferentes dos somatismos impostos pelo modelo econômico.

\subsection{2 - Jacques Copeau e o corpo-criativo}

Nos palcos também se reflete a ode ao corpo e a máscara como instrumento de improvisação renasce com Jacques Copeau (1879-1949) que busca exercitar no ator a qualidade da atuação, a verdade através do domínio físico. Ou seja, potencializar seu estado criativo pela técnica de improvisação como um treinamento, capaz de desenvolver uma poética própria de atuação. Para Copeau a máscara não era um fim, mas um meio, uma concepção idealista que visa resgatar a arte do teatro e proporcionar ao ator uma formação que não dissocia o teatro da dança, da música e das artes acrobáticas. Desta forma, busca na Commedia Dell'arte as habilidades necessárias de improviso e de corporeidade que os atores deveriam ter. Para Copeau, estas máscaras representam e criticam os costumes, as classes sociais, os ofícios, as paixões e os vícios,

\footnotetext{
${ }^{24}$ Taylorismo ou Administração científica é o modelo de administração desenvolvido pelo engenheiro norte-americano Frederick Taylor (1856-1915), considerado o pai da administração científica e um dos primeiros sistematizadores da disciplina científica da Administração de empresas. O taylorismo caracteriza-se pela ênfase nas tarefas, objetivando o aumento da eficiência ao nível operacional. Taylor concentra seu argumento na eficiência do trabalho, que envolve fazer as tarefas de modo mais inteligente e com a máxima economia de esforço. Para isso era preciso selecionar corretamente o operário e treiná-lo na função específica que iria desenvolver.

${ }^{25}$ Fordismo: é um termo criado por Henry Ford, em 1914 refere-se aos sistemas de produção em massa (linha de produção) e gestão idealizados em 1913 pelo empresário americano Henry Ford (1863-1947). Buscava-se assim a eliminação do movimento inútil: o objeto de trabalho era entregue ao operário, em vez de ele ir buscá-lo. Cada operário realizava apenas uma operação simples ou uma pequena etapa da produção. Desta forma não era necessária quase nenhuma qualificação dos trabalhadores.
} 
servindo-se de algumas circunstâncias de situações imaginativas e vivas. Sua ideia não foi recriar nos mínimos detalhes situações jogadas pelos italianos do século XVI e XVII, mas adaptar os tipos e arquétipos às situações modernas, proporcionando uma nova tipologia para o pantalone, arlequino e outros personagens desta linguagem.

A busca por tal modelo surge devido ao seu descontentamento com o teatro francês devido ao seu aspecto comercial, poluído de sensacionalismo, exibicionismo barato e falta de disciplina. Através de seu "Ensaio de renovação dramática”, embora desprovido de postura de vanguarda tão popular nos manifestos artísticos da época, propôs restaurar a beleza no espetáculo cênico preconizando uma simplicidade que permite uma maior expressividade ao ator. No seu pensamento, a máscara juntamente com o palco nu, sem cenário ou figurino, aumenta a presença do ator, direcionando todo foco da cena para si. Um novo ator floresce e experimenta temporariamente a ausência do texto, criando estratégias para que o ator-criador pudesse crescer. Para isto, a máscara torna-se o instrumento mais adequado para a aquisição de uma autonomia criativa, construída e vivenciada antes de viver o seu papel.

Seu objetivo era minimizar os processos racionais como elemento analítico do ator. A partir da neutralidade busca um ator-criador. Enquanto Stanislavski, como relata ICLE (2006), inicia do exterior para buscar a organicidade do ator, acreditando na consciência e na razão analítica como caminho para o inconsciente, Copeau pretende a minimização da consciência, sem perda do controle, através da neutralidade corporal como caminho para se atingir a emoção necessária.

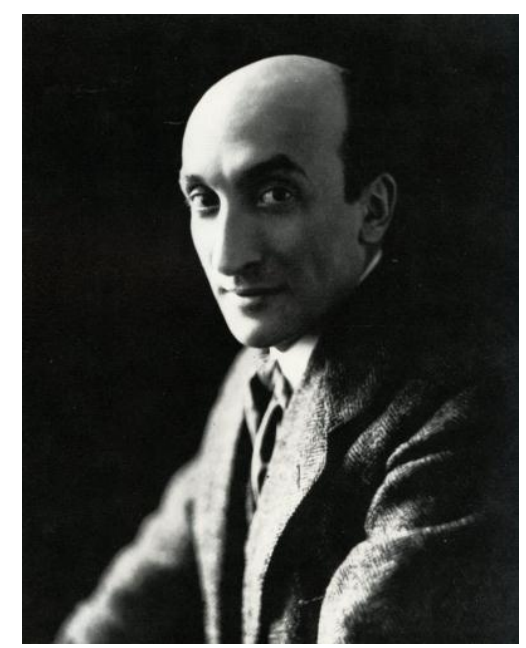

Figura 22 - Jacques Copeau 
Copeau cria o que chama de via negativa. Um método de eliminação onde o diretor-pedagogo suprime os obstáculos do ator, sem enfatizar as ações que funcionam, mas sim aquelas que não servem à representação ou proposta apresentada. Ou seja, apenas com um simples não o professor indica o que o aluno está fazendo errado, sem dizer o porquê e nem enaltece seus acertos. Desta forma o ator pensa e age sobre a consciência de forma particular, eliminando obstáculos cotidianos para se atingir a consciência extracotidiana.

\subsection{3 - O corpo-poético de Jacques Lecoq}

O trabalho de Jacques Lecoq (1921-1999) tem significativa importância quando o que está em questão é o desenvolvimento da máscara teatral no treinamento do atorcriador. Sistematizador de uma pedagogia que se concretizou além das fronteiras francesas, seu método encontra-se hoje enraizado na maioria dos professores desta linguagem. Suas ideias visam uma maior autonomia do ator para além dos gêneros e estilos, sensibilizando-o de sua capacidade expressiva. A "viagem sobre si mesmo" como o próprio Lecoq enfatiza, impele este novo intérprete, através do jogo físico a descoberta de um caminho, onde o mais importante não é interpretar bem a dramaturgia já existente, mas propiciar inteligência, jogo cênico, despertar a curiosidade e a imaginação. "O que lhes permite inventar seu próprio teatro ou interpretar textos, se assim o desejarem, mas de maneira nova”. (LECOQ, 2010, pág.44).

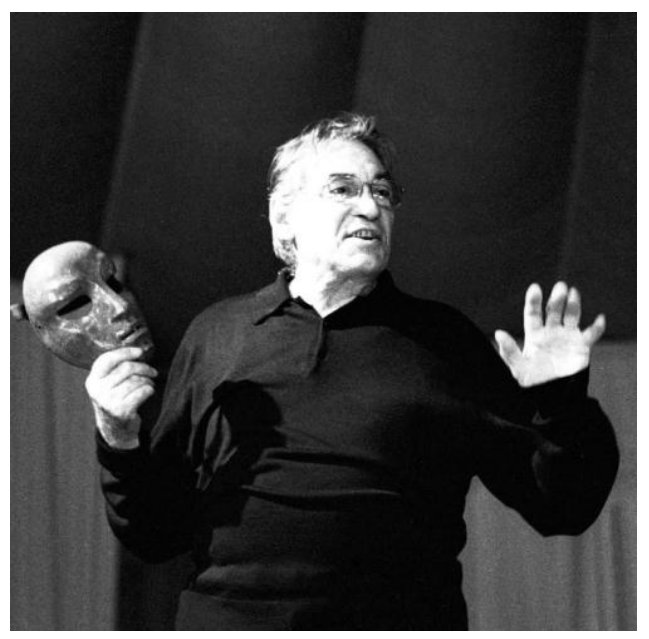

Figura 23 - Jacques Lecoq. 
Em sua pedagogia privilegia-se o mundo exterior, a busca das íntimas sensações, onde ao se favorecer o horizontal, o vertical, o que existe de maneira abstrata, fora de si, o aluno se revelará a ele mesmo. Para Lecoq compreender as leis do movimento é fundamental, principalmente com relação ao ponto fixo que se desenvolve na relação equilíbrio-desequilíbrio na qual alguns elementos como compensação, alternância, impulso, acento, ritmo e espaço atuam. O movimento é uma dinâmica, mais do que um simples deslocamento de um ponto ao outro.

Em sua escola seguem-se exercícios de preparação corporal e vocal, acrobacia dramática e análise de ações físicas. Nesta primeira fase da "viagem" são abordadas as linguagens da poesia, pintura e música. A segunda parte do caminho é concentrada na linguagem dos gestos, preparando a exploração de diferentes territórios dramáticos com aderências poéticas: o melodrama (grandes sentimentos), Commedia dell'arte (comédia humana), os bufões (do grotesco ao mistério), a tragédia (o coro e o herói) e o clown (o burlesco e o absurdo). "Meu objetivo não é "curar" as pessoas por meio do teatro, num processo de criação, o objeto criado não mais pertence a seu criador. O objetivo é realizar o ato de criação: dar um fruto que se desprende da árvore!” (LECOQ, 2010, pág. 45).

Nesta "jornada" a máscara como instrumento pedagógico tem uma importância fundamental como agente de transformação do corpo ao desenvolver essencialmente a presença. O percurso inicia-se com a máscara neutra, trata-se de uma máscara de referência, uma máscara de fundo, uma máscara de apoio para todas as outras. Possui uma aparência simples, sem definição de idade ou personalidade. A máscara neutra é o ponto zero, o vazio, é o momento antes da ação. Tudo para ela é descoberta, é novidade, portanto, não age ou reage de modo convencional. Não possui uma expressão particular, nem uma personagem típica: não ri nem chora, não é triste nem alegre, mas pode ser feliz ou infeliz como todos os humanos. Não tem julgamento ou expectativa em relação a nada, vive apenas o momento presente. $\mathrm{O}$ ator por trás dela coloca-se em estado de descoberta, disponibilidade, permitindo que ele olhe, sinta, toque nas coisas como se fosse a primeira vez. Movimenta-se na medida justa, com economia de movimentos e ações. Ao se colocar no estado de neutralidade sentirá seu corpo disponível, “como uma página em branco" (pág. 69), pronto para atuar. 
Por suas fortes conotações simbólicas e arquetípicas, a máscara exige um suporte filosófico, temático e cultural. Colocá-la em cena acreditando que certos atributos (como forma, pintura, textura) são suficientes para transformá-la em personagem é um engano. Num primeiro impacto, causa estranheza e admiração, mas aos poucos torna-se repetitiva. Não se deve com ela reproduzir o cotidiano como tal. É outro ritmo [...]. Usá-la em cena para fazer o que uma pessoa usualmente faz sem transposição teatral, acaba se criando apenas o anedótico e essa não é sua função dramática. (AMARAL, 2002:7576).

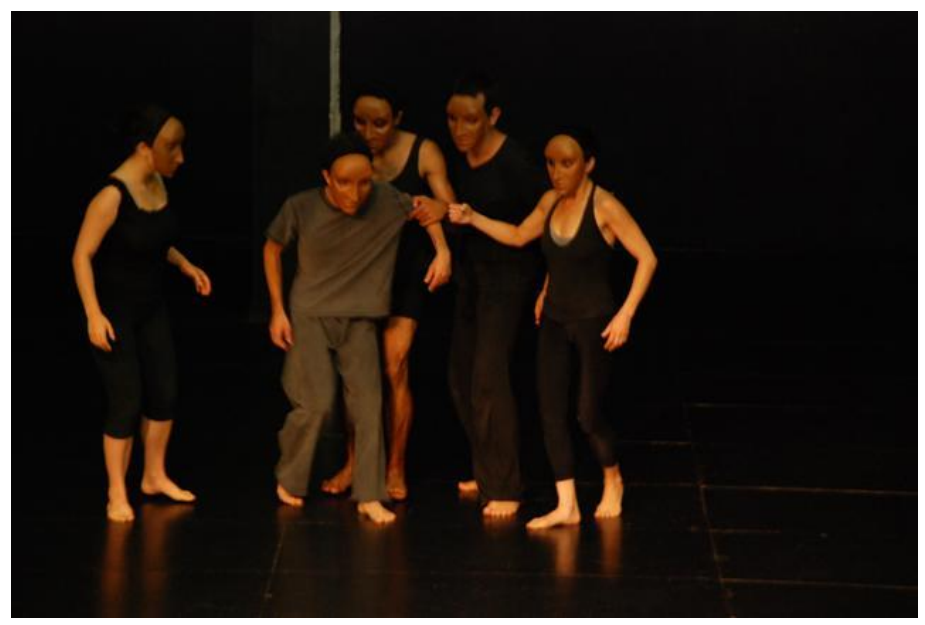

Figura 24 - Núcleo de Máscara - Escola Livre de Teatro. Mostra de processo, máscara neutra - 2009.

O estado de neutralidade é um dos grandes pontos de discussão do trabalho mascarado que não encontra em seu conceito a unanimidade conclusiva, devido a disparidade de visões e entendimentos. Conforme LECOQ (2010) a neutralidade referese a uma atitude interna e relaciona-se às ações ou atitudes denominadas universais. Por assim ser, distancia-se da psicologia de um indivíduo e busca uma essência comum a todos e não ao particular. Há um desafio de transformação identitária, no sentido de despir o mascarado de suas peculiaridades étnicas, culturais, sociais, emocionais e psicológicas. O exercício da máscara neutra requer apreensão de humildade, porém não se trata de subserviência ou de anulação, mas de exercitar para exercer o ser.

Numa segunda etapa entra-se na forma, nas chamadas máscaras larvárias. Formas simplificadas da figura humana: redondas, pontudas, curvas, onde o nariz grande e acentuado dirige toda a face. São geralmente assimétricas, para permitirem diferentes nuances, são grandes, brancas, com a aparência de rostos ainda inacabados. Descobertas nos anos 60 no carnaval da Basel, na Suíça, são bastante elaboradas, finas 
em seus detalhes, suscitam movimentos menores, mais sutis. Expressam sentimentos mais complexos, evidentes em seus traços, compondo, por exemplo, personagens do tipo o "raivoso", o "inteligente", o "narcisista", o "medroso", etc. Permitem um jogo amplo, simples, elementar e altamente poético. Com ela o ator busca um tipo de movimento correspondente a máscara, com uma dinâmica e ritmo próprio.

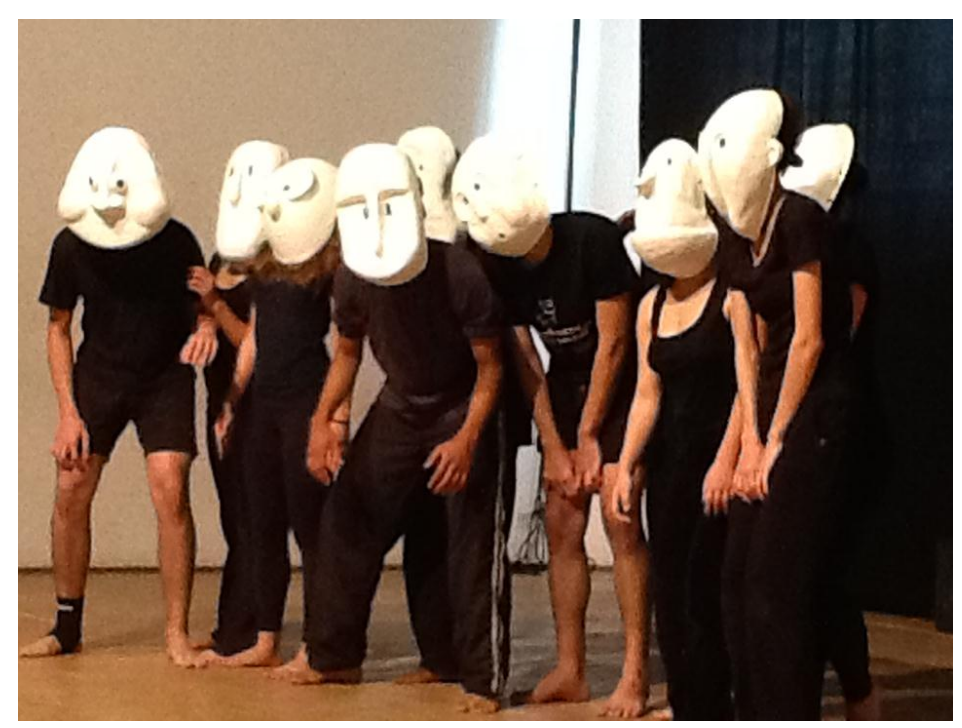

Figura 25 - Máscaras Larvárias - USP - 2013.

Neste processo de descobrimento do corpo expressivo, a percepção tem uma importância ímpar para o ator, tanto do seu corpo como do espaço. Quando recebemos um estímulo do meio, eles são captados pelos órgãos sensoriais e interpretados a partir de nossa subjetividade e experiências. Quem a utiliza pela primeira vez experimentará a sensação de estar dentro de um "casulo" devido aos pequenos orifícios da másca força seu portador a orientar-se pela luz frontal que ilumina a cena para assim poder manterse de frente para a plateia. Sua utilização proporciona ao ator, com o tempo, uma "inteligência" para o jogo cênico, amplitude dos outros sentidos (audição e tato) e a aquisição de repertório de novas situações.

Para LINARES (2010, pág.150) as máscaras larvárias, por terem uma visibilidade reduzida, faz com que a resposta do espectador não seja plenamente recebida pelo ator por meio do seu contato visual. Sua percepção sensorial deve se 
manter preparada no nível de sensibilidade mais aguçado, em estado de prontidão, para receber a resposta do sucesso (ou do insucesso) das suas ações a partir das diversas formas de manifestação do público. É neste sentido que o espectador se torna parceiro e guia orientando-o e conscientizando-o, sem saber, no caminho que o conduz à eficácia da ação cênica.

Um corpo expressivo começa a aparecer pela lógica dos desenhos-animados que as larvárias trazem à cena. Busca-se na animalidade a imaginação, o absurdo e a curiosidade de seus sentidos, que suscita o ator a guiar-se pelos impulsos internos. Aos poucos "concede" ao ator um caminho da sensibilidade com o parceiro no jogo e com o espaço em que está inserido. Deixa-se moldar com a forma, deixa-se entrar na forma. É a pré-expressividade da corporeidade espontânea do ator, é entrar em um mundo com um número infinito de possibilidades.

A jornada da máscara chega ao fim com a Commedia Dell'arte, território das grandes trapaças humanas, que colocam seus desejos, seu estado de sobrevivência acima de tudo. Todos personagens são ao mesmo tempo ingênuos e espertos, regendo através do sexo, da fome ou da ganância seus atos, a ponto de seus instintos essenciais os colocarem em situações cômicas e imaginativas. A Commedia Dell'arte evidencia o trágico limitado da natureza humana, destacando-se pelo domínio corporal, pela arte de substituir longos discursos por alguns signos gestuais e de organizar a representação "coreograficamente".

Surgida na Itália no começo do século XVI era um contraponto ao teatro literário culto e foi inicialmente denominada de commedia all improviso, commedia a soggetto, commedia di zanni. Foi somente no século XVIII que passou realmente a se chamar Commedia dell'arte. Seus atores eram artesões e foram ao contrário dos grupos amadores acadêmicos, os primeiros atores profissionais. Seus ancestrais foram os mimos ambulantes, os prestidigitadores e os improvisadores. Em sua mise-en-scène combina-se, antes do espetáculo, o plano de ação: a intriga, desenvolvimento e solução. Os detalhes eram deixados ao sabor do momento. Uma vez inventado o roteiro 
$\left(\right.$ canovaccio $\left.^{26}\right)$, cada ator improvisa seu começo, meio e fim. Estes momentos conhecidos como $\operatorname{lazzi}^{27}$ são os momentos mais interessantes no espaço de interpretação: é o momento do improviso, onde não há nada escrito. Só o ator poderia por meio do jogo e sua presença cômica criar este momento não presente no texto. Esta técnica de improviso se diferencia da conhecida gag, que segundo Lecoq pode ser "puramente mecânica ou absurda", ao contrário do lazzi que enfatiza sempre um elemento humano do personagem.

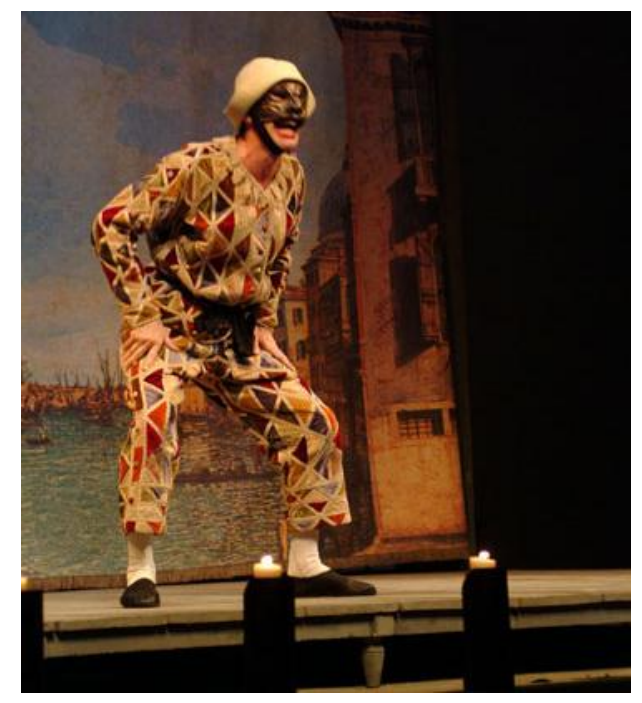

Figura 26 - Enrico Bonavera - Arlecchino, servidor de dois patrões.

Piccolo Teatro di Milano "Arlecchino Tour - New York - 2005.

Em meio ao grotesco, ao rebaixamento, à distorção, o ator é conduzido pelo arquétipo de cada máscara, cada ator utiliza seus recursos físicos e emocionais, com situações levadas ao extremo. A fixação de tipos torna-se seu traço característico devido ao contraste da linguagem, status, sagacidade ou estupidez dos personagens prédeterminados que assegura o efeito cômico. A ideia não é o "que" interpretar, mas, sim, "como" interpretar os diversos personagens. "Sua habilidade de criar personagens diferentes será extremamente valiosa quando, a final do treinamento, o ator tira a

\footnotetext{
${ }^{26}$ É o resumo (o roteiro ou canovaccio) para resumir a intriga ou fixar os jogos de cena. Não lidos como textos literários, mas como partitura constituída de pontos de referência para os atores improvisadores. PAVIS, Patrice. Dicionário de teatro, 2007.

${ }^{27}$ São os elementos mímicos ou de improvisação que servem para caracterizar a personagem. Contorções, rictus, caretas, comportamentos burlescos e clownescos integrados ao texto, como uma maneira refinada de conduzir o diálogo. Uma espécie de encenação de todos os componentes paraverbais do jogo do ator.
} 
máscara e atua sem ela. Ele terá maior flexibilidade de interpretar personagens diferentes ao longo de sua carreira” (LOPES 1991,pág 335).

Todo este trabalho mascarado que Lecoq arregimenta tem como objetivo dar ao corpo a maleabilidade necessária aos diversos papéis que o ator terá de compor, de deixar na lembrança as nuances de corpos poéticos como repertório criativo. Promover um teatro em que o ator esteja em ação, em movimento e que possa não só reconhecer a realidade, mas dar-lhe forma através da imaginação.

\subsection{4 - Novas tecnologias: corpo-projetado/corpo híbrido}

A partir de 1960 as experiências do corpo com o mundo começam a sobrepujar sua dimensão natural. Nasce assim uma nova visibilidade corporal além da fatalidade e finitude, que exerce sobre ele novidades identitárias. Suas doenças, sua sexualidade, gestos, posturas, sua relação com os objetos e o espaço são perpassados pela ciência e pela tecnologia. Os questionamentos sobre seus limites, sobre as suas fronteiras abrem questionamentos entre o individual e o social, o masculino e o feminino, sobre o natural e o artificial, presença e ausência.

De acordo com SANTAELLA (2008) a fragmentação do sujeito, seu desejo de diferenciação, a proliferação das imagens, a virtualização nas redes teleinformáticas, as novas tecnologias médicas e a engenharia genética encorajam as transformações do imaginário e do real. "O corpo tornou-se o lugar privilegiado das técnicas e o destino certo das máquinas" (COUTO, 2001, pág. 87). Torna-se um campo de experimentações artificiais colonizando-o interna e externamente.

O corpo está em todos os lugares, transfigurado nos discursos feministas, na filosofia, nos estudos culturais, nas ciências naturais e na arte. Esta onipresença deve-se ao fato das novas formulações culturais da era digital em escala mundial, que virtualizam o corpo e criam a ilusão (ainda) da simbiose total entre homens e máquinas. Neste pensamento, SANTAELLA (2004) evidencia que a visibilidade do corpo também se deve aos artistas que tentam expor esta antropomorfia que surge no horizonte humano. Desde as vanguardas artísticas, os mascaramentos e os monstros corporais 
foram recheados de rebeldia e resistência à oficialidade da arte, utilizando o corpo como objeto de intervenções cada vez mais híbridas. "Mesmo que estas mutações não sejam visíveis, [...] elas têm estado no cerne da cultura algum tempo [...] pois são os artistas que conseguem dar forma as interrogações humanas que as outras linguagens da cultura ainda não puderam claramente explicitar" (pág.67).

As potencialidades transgressoras das performances e da videoarte a partir de 1970, direcionam as atividades artísticas na contemporaneidade, testam os limites físicos e morais do corpo "histórico", onde os acontecimentos se inscrevem, produto das transformações políticas, culturais, econômicas e estéticas. As mutações ocorridas desde a sociedade industrial produzem a fusão de arte e tecnologia, extraindo do corpo significados. Várias correntes das artes visuais, da dança, da música experimental, das tradições do teatro de vanguarda, aliadas as evoluções midiáticas e da tecnologia combinam forças e efetivam ações que testam os limites da arte e da vida.

Esta densa rede de interconexões procura uma subjetividade e uma identidade contemporânea, a relação da arte com as estruturas de poder, os vários desafios de gênero, raça e etnia, associados aos projetos eugênicos desencadeados pelas correntes do chamado pós-humano estabelecem novos mascaramentos aos corpos. Máscaras que acrescentam ao ser humano parentescos com os monstros imaginários, "que presentificam as incansáveis interrogações da humanidade” (MORAES. 2002 pág.171), as mudanças, as novas conexões que estão por surgir diante dos embates da figura humana com suas alteridades, seja além ou aquém de seus modelos ideais, pelo excesso, pela falta ou pelo extático ou bestial.

O mascaramento e o monstruoso associam-se em novos estratagemas que insinuam um aprofundamento mais intrincado entre seres humanos e máquinas, que ampliam suas possibilidades de prazer e liberdade, como também projetam sua escravização ou mesmo sua transmutação. Estes corpos pós-humanos são refletidos pelas máscaras videográficas de Otávio Donasci e Denis Marleau, que através de suas obras expõem a inquietação e as indagações do corpo diante da virtualidade, da biotecnologia e da teleinformática.

No final do século XX a máscara e o monstro se interpenetram através da tela para expor o retrato atual do pensamento técnico no mundo contemporâneo: as sociedades do controle - prometeicas e fáusticas - que compõem os ideais subjetivos do 
corpo híbrido e da ausência-presença, representativos de corpos-imagens. Este novo homem é daqui em diante fruto de uma sociedade tecnocrata. A combinação de duas partes confere à máscara e ao monstro uma autêntica vocação para a representação. $\mathrm{O}$ que existe neles é o excedente absoluto que se manifesta para além da realidade do objeto, com mais pormenores, com mais conteúdo que uma imagem vulgar, que mostra o irreal verdadeiro. 


\title{
MONSTRO-MÁSCARAS VIDEOGRÁFICAS
}

\begin{abstract}
Ó Adão, não te demos nem um lugar determinado, nem um aspecto que te seja próprio, nem tarefa alguma específica, a fim de que obtenhas e possuas aquele lugar, aquele aspecto, aquela tarefa que tu seguramente desejares, tudo segundo o teu parecer e a tua decisão. A natureza bem definida dos outros seres é refreada por leis por nós prescritas. Tu, pelo contrário, não constrangido por nenhuma limitação, determiná-la-ás para ti, segundo o teu arbítrio, a cujo poder te entreguei. Coloquei-te no meio do mundo para que daí possa olhar melhor tudo o que há no mundo. Não te fizemos celeste nem terreno, nem mortal nem imortal, a fim de que tu, árbitro e soberano artífice de ti mesmo, te plasmasses e te informasses, na forma que tivesses seguramente escolhido. Poderás degenerar até aos seres que são as bestas, poderás regenerar-te até as realidades superiores que são divinas, por decisão do teu ânimo.
\end{abstract}

Oratio Hominis Dignitate, Giovanni Pico della Mirandola ${ }^{28}$

Todo monstro é materialmente uma máscara: seu horror é externo, sua representação se dá por intermédio da fantasia.

Luiz Nazário

\section{CAPÍTULO 3}

\section{UNIR PARA REPRESENTAR}

\footnotetext{
${ }^{28}$ Giovanni Pico della Mirandolla, (1463-1494), foi um erudito, filósofo neoplatônico e humanista do Renascimento italiano. Distinguiu-se dos outros filósofos platônicos florentinos de sua época por seu interesse na síntese da teologia cristã e diversas filosofias, especialmente a cabala judaica. Sua famosa obra Oratio Hominis Dignitate exaltou a dignidade do homem e sua liberdade para influenciar seu próprio desenvolvimento espiritual. Seu pensamento visava o resgate o livre arbítrio conferindo poder ao homem para alterar a direção do destino, corroboraria sua aguçada e prometeica sabedoria de que os astros inclinam, mas não determinam o destino.
} 


\section{1 - A expressão cênica do homem-máquina}

Podemos pensar a arte e as questões preponderantes como uma relação com o tempo e com os pensamentos que ela subjetiva, provocando diversas leituras nas camadas da realidade que nos encontramos. Segundo KERCKHOVE (1997) a arte não é uma saída para as incertezas, mas um meio de entrada para a coletividade de uma existência em construção. A tecnologia, então, seria um conjunto de ideias consensuais, aderidas pelas comunidades tecnofetichistas, que afeta o real, provoca uma leitura, uma rápida absorção de ideias pouco conscientes, mas amplamente massificantes.

Sendo assim, artistas como o videoperformer brasileiro Otávio Donasci e o diretor canadense Denis Marleau são "antenas" conscientes desta realidade, questionando os efeitos dos processos ontológicos do corpo e elaboram perguntas que nos passam despercebidas. Suas obras, também produzidas pela tecnologia, funcionam como agentes críticos dos efeitos da hibridização homem-máquina. Nesta crítica que une o conceito da máscara com a forma do monstro, os antigos dualismos e fronteiras que caracterizam a cultura tradicional são colocados em xeque: eu-outro, corpo-mente, criador-criatura, real e irreal, presença e ausência. Suas monstro-máscaras videográficas configuram uma forma com direito a diferença e individualidade, dentro de possíveis pluralidades de criação e invenção do humano. São espelhos que oferecem ao espectador momentos de estranheza e reflexão diante da iminente transumanização, associando o specimen (aparência, forma de) e o spectrum (espectro, aparição, fantasma) com o vídeo.

As monstro-máscaras videográficas se concretizam numa perspectiva expressiva de máquinas semióticas com extraordinária capacidade de metamorfose, sujeitas as anamorfoses na conjunção corpo e vídeo. Conforme MACHADO (1993) pode-se intervir infinitamente sobre o vídeo, subverter valores, alterar seus valores cromáticos, recortar figuras e utilizar uma gama de técnicas que geram paisagens híbridas e exóticas. Diferente da imagem fotográfica e a cinematográfica, a imagem eletrônica caracteriza-se por ser mais elástica, diluível e manipulável, como uma massa de modelar. Donasci/Marleau subvertem a máquina, proporcionando às suas criações possibilidades e significados que redefinem a maneira de nos relacionarmos com determinado meio. Ao passo que, também neste novo jogo, "antecipam, respondem ou 
complementam a ação no devir da cena" (SILVA, 2008, pág. 122), habilidades que geram uma intermediação entre linguagens.

Sendo assim, proporcionam um grande close-up de uma realidade calcada nas correntes técnicas. Traduzem os ideais prometeicos e fáusticos da imagem do corpo, de seu controle, de sua longevidade e manipulação, idealizando a hiper-realidade ou até mesmo a perda de seu suporte biológico/material que as conquistas científicas colocam como propostas de alteridade humana.

\title{
3.2 - Sociedades da técnica - de Prometeu a Fausto.
}

\author{
Prometeu \\ Sim, curei nos homens a preocupação da \\ morte. \\ Coreuta \\ Que remédio achaste para este mal? \\ Prometeu \\ Alojei neles às cegas esperanças. \\ Coreuta \\ Foi esse um dom utilíssimo para a \\ Humanidade. \\ Prometeu \\ Além disso, dei-lhes de presente o fogo. \\ Coreuta \\ Os efêmeros possuem agora o fogo \\ chamejante? \\ Prometeu \\ Sim, e dele aprenderão artes sem conta. \\ Prometeu Acorrentado, Ésquilo
}

As poéticas de Marleau e Donasci estão correlacionadas às sociedades de controle, com a ideia de artefatos técnicos como extensões amplificadas do ser humano, que se tornaram o centro do pensamento moderno. Uma das primeiras exposições sistemáticas sobre o tema foi publicado em 1877 por Ernst Kapp (1808-1896), hegeliano de formação que cria a teoria antropológica da tecnologia, que formula que ferramentas primitivas são facilmente vistas como projeções orgânicas, de partes do corpo. Por exemplo, a mão em concha teria gerado ferramentas como pás, colheres e 
outros artefatos, como o punho cerrado seria análogo ao martelo e muitas espécies de armas. As invenções correspondentes ao tempo de Kapp são criadas de forma equivalente com as estruturas internas do corpo humano: o cabo telegráfico elétrico é comparado aos nervos e os caminhos de ferro ao aparelho circulatório.

Ao formular tal teoria, Kapp também elabora uma teoria antropológica da tecnologia, onde o inconsciente produz diversas externalizações técnicas, que projeta traços e fases do ser humano. Uma vez produzidos, tais artefatos proporcionam ao homem alcançar o conhecimento de si mesmo. A compreensão da natureza humana não estaria na introspecção ou no estudo do comportamento, mas no estudo dos produtos oriundos do trabalho humano, sobretudo dos artefatos técnicos. Em sua formulação não existe a alienação tecnológica, pelo simples fato de Kapp enxergar a tecnologia como desalienante. A externalização do inconsciente via técnica orgânica oferece, de certa forma, uma garantia de crescimento da autoconsciência humana. Esta concepção técnica para MARTINS (1996) trata-se de um somatismo tecnológico (prometeico), devido à ênfase posta no ser humano corporizado como modelo analógico de toda invenção.

A correlação entre tecnologia e corpo humano também está presente no princípio da auto-amputação. As pesquisas médicas de Hans Selye e Adolphe Jonas sustentam que nosso organismo, ao lidar com um "excesso" ou "irritação" na saúde ou na doença, age de forma auto-imputiva toda vez que nossa energia perceptiva não consegue evitar ou localizar a causa do excesso. Muitas vezes para dar vazão a este excedente criamos situações artificiais que imitam as irritações e pressões da vida, de forma controlada (esporte e jogo). Sob pressão de estímulos físicos, o sistema nervoso central reage para proteger-se através de um estratagema que implica na amputação ou isolamento do órgão, sentido ou função atingida. Desta forma, "o princípio da auto-amputação como alívio imediato prontamente se aplica à origem dos meios de comunicação, desde a fala até o computador" 29 . Esta teoria explica as invenções humanas como extensões do nosso corpo, exigindo sempre novas relações e equilíbrios, modificações que atendem os desejos e aspirações humanas.

\footnotetext{
${ }^{29}$ MCLUHAN, Marshall. Os meios de comunicação como extensões do homem, págs. 60-62.
} 
Hoje o somatismo tecnológico de Kapp de prioridade do orgânico sobre o mecânico é colocada em risco pelas biotecnologias contemporâneas e pelo impulso da mecanização da vida. Para atual tecnociência, o inconsciente é trocado por sistemas de processamento de informação. Nesta configuração, a tecnologia é a chave para a antropologia: gnosticismo tecnológico (fáustico). A manipulação do mundo material, com a transcendência da condição humana, busca ultrapassar parâmetros básicos como finitude e corporalidade, gerando novas criações que apontam para a superação das limitações próprias ao orgânico. A biotecnologia, por exemplo, não busca apenas aperfeiçoamentos cosméticos ou protéticos para organismos humanos e não-humanos, mas têm finalidade a criação de novas formas de vida, vidas mistas, biológicas e mecânicas.

Para SIMODON (2008) a técnica apresenta-se pelo emprego dos objetos para solução dos problemas e apresenta-se como uma estrutura da relação do homem com o mundo. Na sociedade da técnica, o objeto é visto como sagrado, a idolatria da máquina por meio de identificação é uma aspiração tecnocrata ao poder incondicional, conotando a máquina como elixir moderno. Com a intenção de melhorar ou controlar totalmente os rumos da natureza humana, as máquinas são pensadas como duplo, como projeções técnicas de um devir a muito tempo pensado de coexistência. "Assim, o homem tem por função ser o coordenador e o inventor permanente das máquinas que estão à sua volta. Ele está entre as máquinas que operam com ele" (pág. 12), delegando ao Homem a função de arquiteto de si mesmo.

A realidade técnica torna-se então reguladora e integra-se à cultura. Essa integração torna-se fundamento que trará um poder de unidade e de estabilidade, ao tornar adequada à realidade que exprime e regula. Desta forma, o sociólogo português Hermínio Martins utiliza duas figuras míticas da cultura ocidental para demonstrar as diferenças entre a sociedade moderna e contemporânea: Prometeu e Fausto, arquétipos utilizados para analisar o pensamento ocidental sobre a técnica. Inseridos na lei do eterno retorno, as monstro-máscaras videográficas de Donasci carregam ideais prometeicos de corpo obsoleto, de acoplamentos e do ciborgue. Por sua vez, Marleau assimila em sua poética influências fáusticas de controle do corpo, da questão de sua ausência e transferência da mente humana para organismos cibernéticos. 


\section{3 - Sociedade prometeica}

Antes de mim eles viam, mas viam mal; eles ouviam, mas não compreendiam. Tais como os fantasmas que vemos em sonhos, viviam eles, séculos a fio, confundindo tudo.

Prometeu Acorrentado - Ésquilo

A sociedade prometeica tem raízes no positivismo francês com Saint-Simon, que pretendia consertar a violência das políticas revolucionárias. Em sua visão a técnica representa um grande instrumento, rápido e completo de melhoramento do ser humano. Uma sociedade calcada no progresso científico industrial permitiria ultrapassar as estruturas de opressão humana. A ação do homem deve ser exercida sobre as coisas e não sobre outro homem, sendo que esta última ação é prejudicial à espécie.

Prometeu no idioma grego significa 'premeditação', 'antevisão'. Na mitologia grega, segundo Hesíodo, foi dado a este titã, juntamente com seu irmão Epimeteu, a tarefa de criar os homens e todos os animais. Epimeteu encarrega-se da criação e Prometeu assume a função de supervisor. Na obra, são atribuídos a cada animal os mais variados dons: coragem, força, rapidez, sagacidade; asas a um, garras a outro, uma carapaça protegendo um terceiro etc. Porém, quando chegou a vez do homem, Epimeteu gastara todos os recursos nos outros animais. Recorre então ao seu irmão Prometeu que rouba o fogo dos deuses e o entrega aos homens, assegurando sua superioridade sobre os outros animais. Todavia o fogo era exclusivo dos deuses. Como castigo a Prometeu, Zeus ordenou a Hefesto que o acorrentasse no cume do monte Cáucaso, onde todos os dias uma águia (ou corvo) dilacerava o seu fígado, que se regenerava no dia posterior, impondo-lhe um suplício sem fim. Prometeu é um símbolo de revolta contra o poder real ou aparentemente indestrutível e inalcançável. É a não submissão ao destino que se apresenta como certo. "É o símbolo do inconformismo. Em sua ação premeditada, a metáfora de Prometeu confere ao homem a tecnologia e de certa forma denuncia a arrogância da humanidade em sua tentativa de usurpar as prerrogativas divinas por meio de artimanhas e saberes terrenos" (SIBILIA, 2003. Pág.43). 


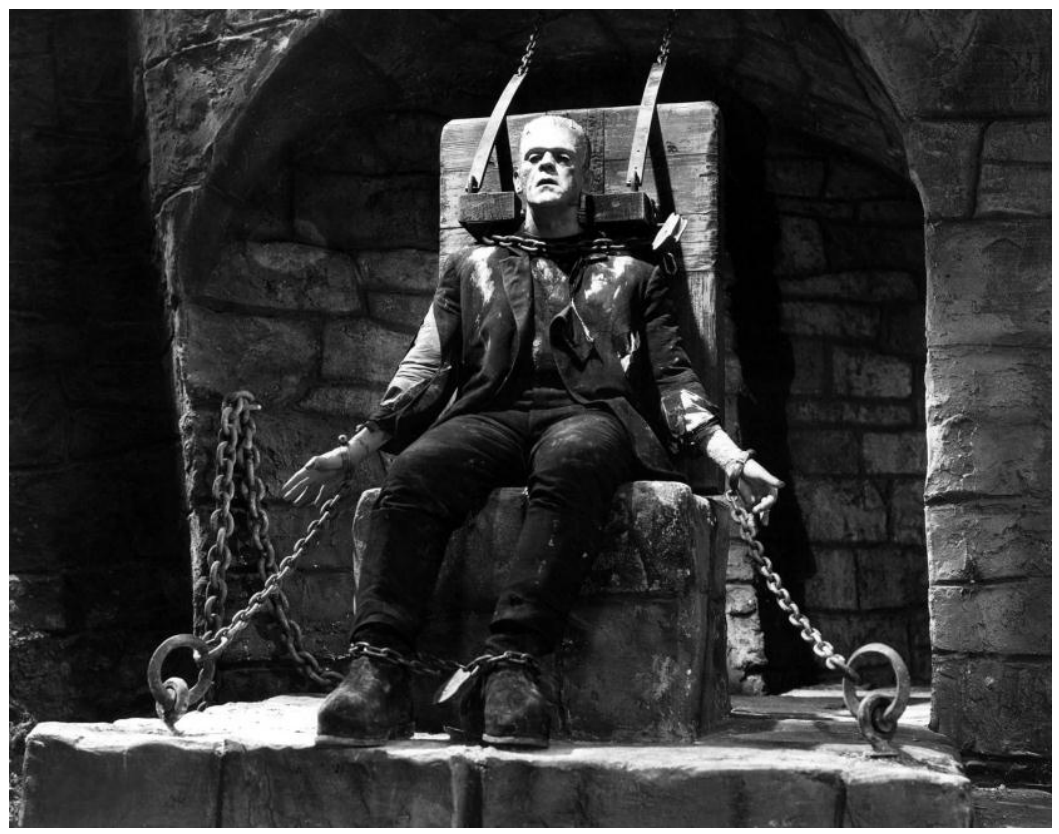

Figura 27 - The bride of Frankenstein. Filme de James Whale (1935).

As aspirações da sociedade prometeica se formaram na primeira metade do século XIX por meio do conhecimento científico. Confiantes no progresso, os defensores do prometeísmo colocam ênfase na ciência como "conhecimento puro" e têm a visão meramente instrumental da técnica. Ao menos teoricamente, o desenvolvimento gradativo deste tipo de saber levaria à construção de uma sociedade racional, "assentada em uma sólida base científico-industrial capaz de acabar com a miséria humana" (SIBILIA, 2003, pág.44). Com base no positivismo tecnocrático, a ciência e a tecnologia operariam juntas para a salvação do ser humano e do cosmo.

[...] a história do prometeismo tecnológico: a vida orgânica nunca será compreendida de modo tão fundamental - pelo menos no que a cognição científica respeita - quando o mundo físico ou humano, ambos os quais são susceptíveis de indefinida mecanização, de uma maneira que a vida orgânica não o seria nunca. A ostensiva refutação desta limitativa tese pelos recentes avanços da genética e da biologia molecular e o fluxo de biotecnologias cada vez mais largamente aplicadas e mais potentes que as implementam dá corpo a um espectro de mecanização planetária universal [...] (MARTINS; 1997 pág.296). 
As ferramentas prometeicas sobejam certo aperfeiçoamento do corpo de forma naturalista e não transcendentalista. Em sua visão, os artefatos técnicos compõem extensões, projeções e amplificações das capacidades corporais, que criam Frankensteins modernos, que trocam os quebra-cabeças da carne por conjunções com o silício e submetem a vida orgânica à mecanização.

O corpo-máquina prometeico criado através da técnica é pensado como aumento da longevidade humana, mas não na extinção de sua finitude. Para tais cientistas existe um terreno onde o que não é passível de explicação fica a cargo do sagrado, do divino. Os prometeístas consideram que há limites com relação ao que pode ser conhecido, feito e criado. Os mistérios da origem da vida e da evolução biológica estão fora do alcance da racionalidade científica.

O corpo então, neste processo, torna-se receptáculo de identidades flexíveis (máscaras) que se unifica com novas próteses artificiais, atualizando o imaginário e o cotidiano humano. E através da arte, o potencial de novas configurações se vislumbram em possíveis desdobramentos político-sociais.

\section{4 - Otávio Donasci - a tela como segunda pele}

Artista performático e professor das Artes do Corpo da PUC-SP, Donasci é um visionário, um ser múltiplo, multifacetado como as criaturas videográficas que cria. Desde criança já montava seus próprios computadores, tinha fascinação por desmontar os mais variados objetos, só pelo prazer de saber como eram feitos, o que lhe rendeu uma curiosidade técnica que o tornaria um dos pioneiros da videoarte no Brasil. Conhecido no cenário teatral performático e audiovisual do país, atuou como diretor de criação em agências publicitárias, de espetáculos multimídia, produtor de eventos especiais e cenógrafo. Por este último, recebeu os prêmios APCA e Mambembe (1994) pelo conjunto de sua obra. Com suas videocriaturas participou da maioria dos festivais de vídeo e arte eletrônica do exterior (Nova York, Paris, Berlim, Montreal, Lisboa, Kyoto etc.), além de participar de três Bienais Internacionais de São Paulo. No início de 1990, trabalhando em conjunto com o diretor Ricardo Karman, criou as Expedições Experimentais Multimídia: Viagem ao Centro da Terra (1992) e a Grande Viagem de 
Merlin (1994), gigantescos espetáculos interativos que envolviam teatro, turismo e artes plásticas.

As videocriaturas do Otávio Donasci são desenvolvidas desde 1981, criadas através de monitores de vídeo low-tech acoplados ao corpo de performers por intermédio de próteses ortopédicas, que até hoje causam estranhamento. Para MELLO (2008), Donasci mistura o conceito da máscara com o elétron, com rostos virtuais eletrônicos aplicados sobre um segundo corpo real. Uma interface homem-máquina, mistura de vídeo, teatro e performance, revelando o próprio princípio da intermídia, em que o trânsito existente entre uma e outra linguagem é capaz de conceber uma nova categoria expressiva.

Suas monstro-máscaras videográficas construídas a partir de televisores preto e branco, telas de cristal líquido e televisores de plasma são fixadas na cabeça de um ator. Os monitores podem ser ligados por intermédio de cabos a um videocassete ou a uma câmera de baixa performance sem fios. O figurino é composto de uma malha preta com um capuz do mesmo material que cobre também todo equipamento. Esta malha semitransparente confere ao performer ver sem ser visto e poder se locomover pelo espaço, enquanto a tela de monitor mostra a imagem de um rosto recitando monólogos ou diálogos improvisados, real-time, com o público ou com outras videocriaturas.

Nas primeiras intervenções, o rosto da monstro-máscara é pré-gravado, mas ao longo dos avanços tecnológicos, a exibição do rosto passa a ser em tempo real, condição que permitiu a improvisação, a interatividade e várias outras criações: videotauro (1985), um cavalo com um monitor de TV de 20 polegadas no lugar da cabeça circulou pelas ruas do Bixiga, com um capitalista selvagem dentro de uma jaula. O videobusto (1986), composto por um busto de fiberglass com rosto de monitor. A obra foi exposta nos 80 anos da Pinacoteca do Estado de São Paulo e o busto videográfico conversava o tempo todo com as pessoas que entravam no museu. O videovivo (1989), performance feita com Ana Lívia Cordeiro, onde eram projetadas imagens tridimensionais que contracenavam com o ator em cena. Apresentação feita na $20^{\mathrm{a}}$ Bienal de São Paulo. Videopersonas (1990), personagens criados a partir de efeitos de edição imitando as videocriaturas. Com formas variadas, os personagens têm duas bocas e cantam em dueto; outro tem a cabeça inversa e fala de trás para frente etc. Os videomanequins 
(1991), criados da junção de corpos de manequins e monitores de cinco polegadas, onde são exibidos rostos pré-gravados de um banco de dados. Em outro momento os videomanequins estavam em um salão de baile à meia-luz, com música romântica ambiente. Eram oferecidos ao público três videomanequins com rodinhas para dançar e namorar, provocando toques e reações afetivas.

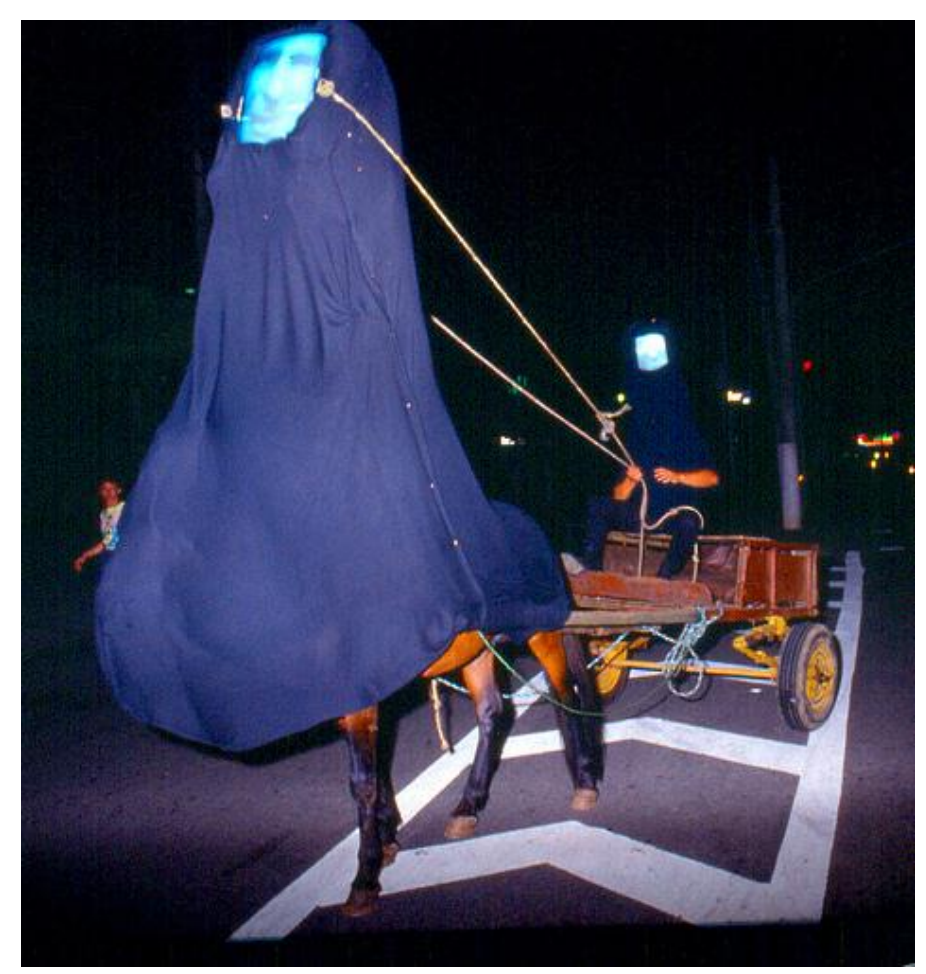

Figura 28 - Videotauro

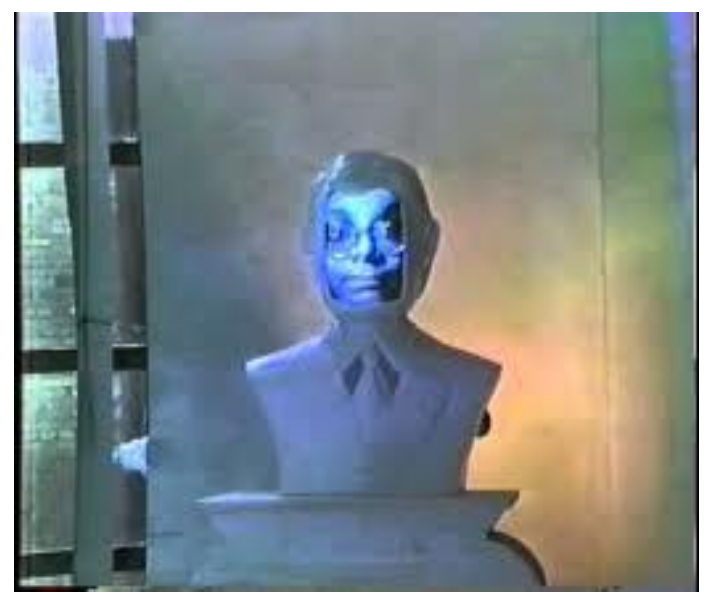

Figura 29 - Videobusto 


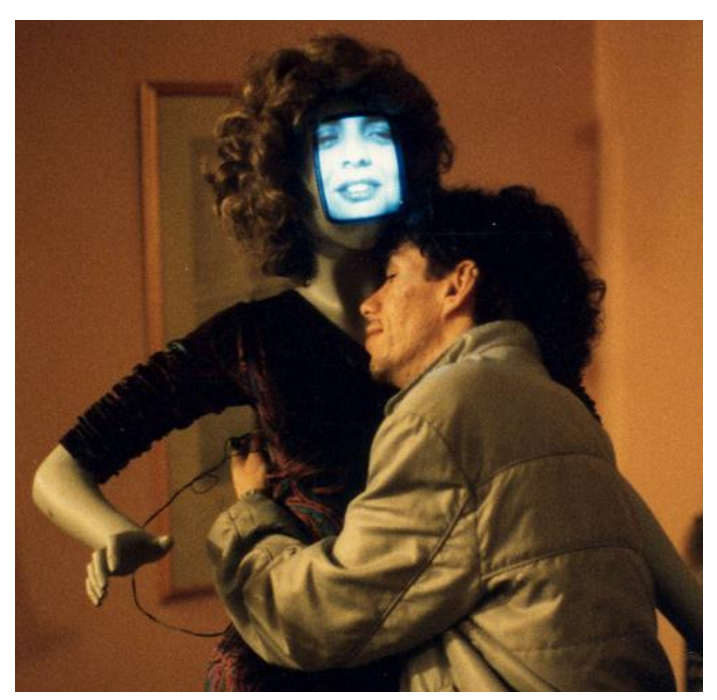

Figura 30 - videomanequim - IX VIDEOBRASIL SESC - Pompeia. SP - 1992.

A trajetória de Donasci confunde-se com a trajetória do vídeo no Brasil a partir de 1980, quando formas alternativas midiáticas surgem, como as televisões locais de pequeno alcance, TVs comunitárias e pequenas produtoras, que chamam a atenção dos produtores independentes como formas de ações qualitativas. O vídeo é a ferramenta utilizada para discutir o mundo contemporâneo. Uma fase de pluralismo e hibridização cultural que surge com o cinema de vanguarda e seu entrecruzamento com as artes visuais. Contaminações culturais e de linguagem que levam o vídeo a uma visão descentralizada, um processo de misturas entre o cinema, a performance, a televisão, a música, a arquitetura, o espírito pop e os computadores. Neste contexto, os artistas estão mais centrados nas possibilidades alternativas que o vídeo proporciona, numa maior articulação do quadro videográfico, apontando tanto para o acaso e a imprevisibilidade como para a formalização e estruturação da ação estética. "Tais processos desestabilizam as formas convencionais de produção do signo eletrônico e transitam em torno do deslocamento poético dos sentidos" (MELLO, 2008, pág. 116). Nesta procura por transcender a "caixa preta”, a desconstrução do vídeo amplia as capacidades discursivas da arte contemporânea.

A multiplicidade de formas de suas monstro-máscaras deve-se especialmente pelas características da personalidade plural de Donasci, sempre interessado em uma infinidade de técnicas que com o passar do tempo, foi descobrindo, desenvolvendo e 
melhorando. Para Donasci aceitar as coisas como parecem, como elas são, como estão, é algo totalmente insatisfatório. Sua inquietude perante a vida, de sua profunda vontade de um conhecimento multifacetado: teatro, cinema, artes plásticas, vídeo, publicidade, desenho ou engenharia elétrica faz dele um artista-cientista pós-moderno. Demonstra em sua obra a metáfora da busca prometeica de um ser híbrido, de um ser humano que busca a conjugação maquínica proveniente da sociedade de controle. Um monstro "luminoso iluminado", como ele mesmo afirma.

\subsection{1 - o mito de Frankenstein}

Contemplei o coitado[...] o desgraçado monstro que eu havia criado.

Frankenstein, Mary Shelley

O nascimento do livro, conforme a autora mesmo descreve em seu prefácio, deve-se ao desafio de lorde Byron em uma reunião de amigos para que cada um escrevesse um conto sobrenatural, e efetivamente a história de Mary Shelley foi a única a se concretizar. A ideia da obra partiu de uma conversa ouvida pela autora entre seu marido e Byron sobre a criação artificial da vida e sobre as experiências de um mencionado Edward Darwin (avô do famoso naturalista). Seu monstro se baseia nas angústias e paixões humanas e, entre elas, a tentativa do controle da natureza humana sobre a vida e a morte.

A similitude do monstro de Shelley com os de Donasci cria a prerrogativa neopositivista de um enorme fascínio da melhoria do corpo através de aparatos eletrônicos. O moderno prometeu tem como premissa básica a criação de um serhumano, de um super-humano, construído por partes de corpos a partir da ciência. Nesta era de informação conforme STELARC (1997) a liberdade de forma está acima da liberdade de ideias, de modificar o corpo como se quer. "Quando acoplamos ou implantamos dispositivos protéticos para prolongar a vida de uma pessoa, também 
criamos um potencial para impulsionar o desenvolvimento pós-evolutivo. Pessoas remendadas são experimentos pós-evolutivos ”(pág.53).

Na conjunção corpo e imagem, Donasci cria um terceiro ser, um ser híbrido tipicamente prometeico. “Ao vestir a máscara eletrônica, senti meu corpo se deixar levar pelo comando desse rosto, como que tomado por outro ser arrancando de mim expressões performáticas desconhecidas. Senti que formávamos - eu e a imagem do rosto do ator fundida - uma terceira pessoa, híbrida de nós, diferente de nós, potencialização de nossas expressões e ao mesmo tempo estranho para nós". (DONASCI. 2002, pág.9). Donasci então subjetiva o ciborgue, um sistema homemmáquina autorregulado a fim de se adaptar sutilmente às condições de existência humana. Esta nova configuração confere ao ciborgue um controle regular pela técnica que interfere no funcionamento de seus comportamentos. O corpo eletrônico quer a perfeição, longe da doença, da deficiência, dissolve-se num universo de dados que o separa da simbiose edipiana.

O corpo ciborgue não é inocente, não nasceu em um jardim; não busca identidade unitária e assim gera dualismos conflituais sem fim (a não ser o fim do mundo); considera a ironia a evidência [...]. A máquina é [...] um aspecto de nossa encarnação. Podemos ser responsáveis por ela, ela não nos domina; somos ela mesma. (HARAWAY, 1990, pág.160).

A tecnologia não é apenas presa ao corpo, mas sim implantada, oferecendo a cada pessoa a possibilidade, o potencial de evoluir individualmente, num desenvolvimento onde a coesão da espécie não é mais a distinção corpo-mente e, sim, a divisão corpo-espécie. Faculta assim numa consciência alternativa, pós-histórica, transumana. A questão não é mais mecanizar o corpo: é reprojetá-lo, torná-lo mais compatível com as máquinas e aumentar sua performance por longos períodos. Neste formato o indivíduo tende a ser um produto que não decide sua orientação e existência, o corpo é um empreendimento a ser administrado para aumento das potencialidades de memória, de processamento de informações, de capacidade extra-sensorial e de habilidade expandida de comunicação. 
Este futuro que a imagem das monstro-máscaras alude populariza a ideia de fábrica de órgãos, viabiliza a possibilidade de reposição de uma peça caso tenhamos alguma avaria ou mau funcionamento. O interno do corpo não cessa de ser revelado, modificado e planejado. Como também o corpo passa a ser considerado uma mercadoria, que deve circular e abastecer um novo mercado. No passado conhecemos diversas formas de comércio do corpo humano: a posse de indivíduos (escravidão), a prostituição em diversos níveis e o trabalho assalariado, que de certa forma se baseia num modelo de utilização das capacidades físicas e intelectuais.

No capitalismo avançado, o corpo é remodelado constantemente e como caráter preponderante do próprio sistema, a prática de consumo deve ser rápida e descartável. Com este pensamento, as peças corporais internas ou externas devem ser incessantemente substituídas para que o corpo possa durar indefinidamente. Passamos então a ser um produto comprado e vendido como mercadoria. Assim, construímos a eficiência na qual as pessoas que se orientam por tal culto, comprometidas com a transfiguração e a remodelagem, são socialmente aceitas, integradas, idolatradas, invejadas e copiadas. Em contrapartida, pessoas pouco comprometidas, pouco afáveis às obrigatoriedades de mutação, dispostas a não cooperar com a nova configuração, são consideradas irresponsáveis, culpadas por seus próprios defeitos e deficiências corporais.

Franskenstein é uma colcha de retalhos, um monstro prometeico com pedaços de corpos sem identidade, sem referências, que volta-se contra seu criador pelo desejo de vingança pelo abandono. A queda de Victor Frankenstein, criador do monstro, acontece quando não consegue perceber as intricadas relações com sua própria criatura e que suas atitudes, como aversão e repúdio ao que acabara de criar, acarretaria em desastrosas consequências. Donasci coloca em cena a questão da democracia corporal, da excessiva exaltação da confluência maquínica, como também da mutabilidade determinada como projeto central pela sociedade prometeica, onde a técnica exerce o papel de axioma inquestionável. 


\subsection{2 - A técnica por trás da técnica}

A relação do trinômio: corpo, imagem e técnica tão conjurada em nossos tempos fica evidente numa experiência pessoal que proporcionou duas distintas utilizações da monstro-máscara videográfica. Na década de 90 numa demonstração de Donasci, experimento a sensação de estar no corpo da videocriatura. Coloco o capacete, o televisor em minha cabeça é ajustado e o tecido translúcido preto desce diante do meu rosto. Depois de tal ritual, uma ansiedade toma conta de meu corpo. Estava ali, perdido, num mundo a parte, por mais que minha audição estivesse excitada, por mais que a vontade de experimentação fosse enorme, meus gestos, minha disposição no espaço, minhas "caretas" por detrás da máscara, tentando antecipar, adivinhar o que a cabeça eletrônica tentava falar foram em vão.

Tudo parecia caótico: as mãos se agitam, a noção de tempo e espaço se confunde, meu corpo atabalhoadamente propunha ações demais, não havia o tempo de escuta, acarretando um nervosismo maior que o prazer de atuar, maior que o prazer da experimentação. Meu corpo não entendeu, não compreendeu o que aquele ser pedia. Nesta época não tinha nenhuma noção corporal ou simplesmente "técnica" alguma, apenas a vontade de entender, de ser outro. A tentativa foi frustrante, mas não menos instigante por saber que o meu corpo poderia criar novas nuances, novas organizações criativas.

Contudo, em 2011, vários eventos marcam os 30 anos das videocriaturas e a Oficina Cultural Oswald de Andrade promove uma palestra prática com Donasci. Novamente ali estou, pronto para utilizar a videocriatura, para entrar novamente naquele mundo que me pedia algo mais. Mais uma vez escolho ser o corpo da criatura, mas diferentemente do que acontecera há 20 anos, minha atuação foi diferente, mais pontual e centrada. Hoje percebo que um dos motivos entre a primeira e a segunda utilização foram a aquisição de variadas técnicas corporais como linguagem da máscara teatral, improvisação, mímica corporal dramática, arte acrobática, artes marciais, yoga, e práticas de consciência do movimento como os sistemas de Laban e Feldenkrais. "[...] O importante é crer que não é qualquer pessoa que pode fazêe-lo, e que para isso é preciso uma preparação" (ARTAUD, 1999, pág.5). 
Ao colocar a monstro-máscara meu corpo automaticamente assume uma postura extracotidiana, tem energia, ganha ritmo e um compasso sincronizado com o rosto eletrônico foi estabelecido. Os gestos se não são precisos, são ponderados, intercalando acelerações em alguns momentos; lentidão e pausas em outros. Respeito frontal que a máscara exigia estava ali, uma movimentação pelo espaço consciente se sucedia, o improviso funcionava e acima de tudo o jogo tornou-se mais consciente, mais claro. A partir daquele instante a noção cartesiana, da divisão mente e corpo se esvaiu, o corpo tornou-se uma máscara, um intermediário entre dois mundos, que ritualizava aquele instante na metamorfose da forma.

$\mathrm{Na}$ psicologia da Gestalt ${ }^{30}$, a percepção das formas está relacionada a lei da pregnância que afirma que a recepção de uma imagem será boa sempre que as condições também sejam, ou seja, será imposto à percepção a imagem que possuir a melhor, mais estável e mais conhecida configuração. Donasci com sua monstro-máscara de baixa definição tenta vencer as formas pregnantes de um sistema, causando estranhamento em sua nova configuração. Sendo assim, a imagem do vídeo pequena, sem profundidade, de efeito ilusório precário não fascina o espectador, pelo contrário, o estimula a um distanciamento crítico.

A "forma é configuração visível do conteúdo", segundo ARHEIM (1980) e esta configuração serve para informar sobre a essência das coisas através de seu aspecto externo. Além disso, a forma sempre ultrapassa sua função prática encontrando em sua configuração qualidades visuais como força ou fragilidade, harmonia ou discordância. Todas as vezes que constatamos a existência de uma configuração, consciente ou inconscientemente a tomamos como representação da forma de um conteúdo e quando as formas se desestabilizam, as partes dos corpos tornam-se permutáveis.

\footnotetext{
${ }^{30}$ A Psicologia da Gestalt originou-se na Alemanha, entre 1910 e 1912. A tradução da palavra alemã "Gestalt" é complexa e os termos, em português, que mais se aproximam de sua tradução seriam "forma", "configuração". Os três pesquisadores que marcaram essa corrente teórica foram Marx Wertheimer, Kurt Koffka e Wolfgang Köhler. Esses pesquisadores embasaram-se nos estudos psicofísicos - os quais relacionaram a forma e sua percepção. Seus experimentos iniciaram-se com relação à percepção e sensação do movimento. Visavam entender os processos psicológicos envolvidos na ilusão de ótica, quando o estímulo físico percebido pelo sujeito possui uma forma diferente da que corresponde à realidade.
} 


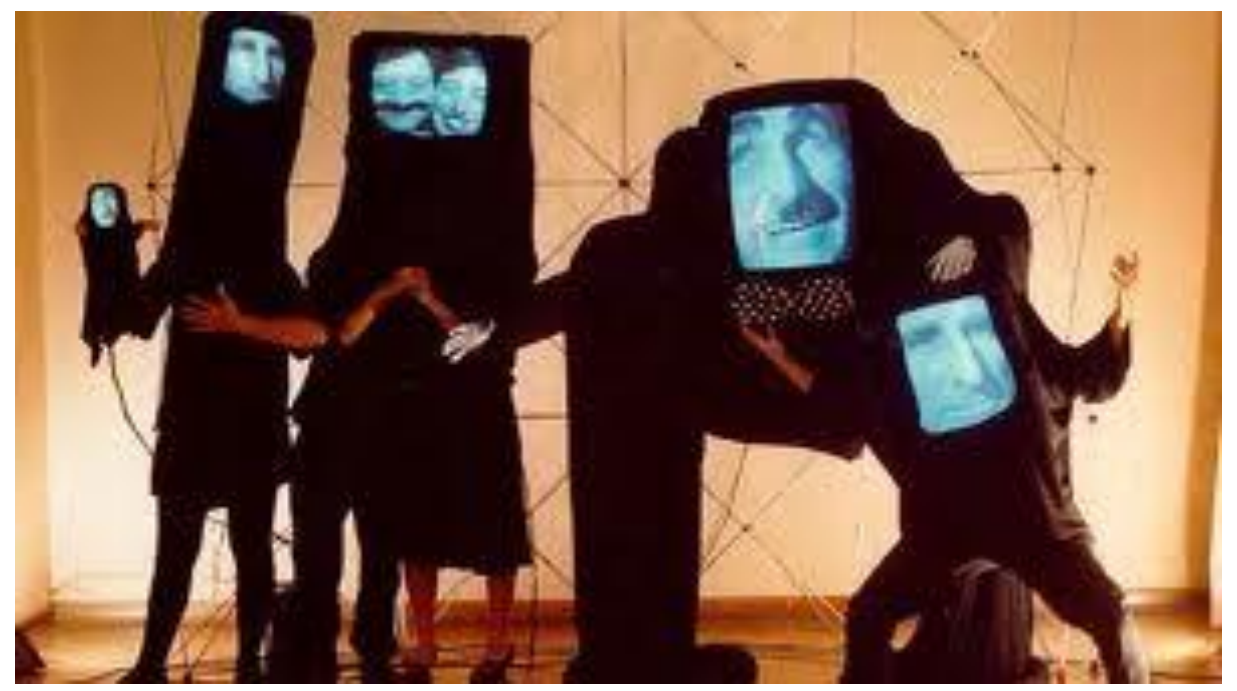

Figura 31 - Videocriaturas Família ${ }^{31}$

Libertados de suas aparências, de suas propriedades físicas, são dotados de um poder de migração e instaura-se um tempo, uma atmosfera. "Os objetos [...] obedecem, quase sempre, a [...] disposição de intercâmbio entre o [...] natural e o artificial" (MORAES, 2002, pág. 76-77). A recusa do pensamento dualista anula os contrários e fornece ao objeto o estatuto de analogias transmutacionais. Sendo assim, a analogia do corpo e o rosto eletrônico valem-se de ajustamentos, tramando um grande número de parentescos, multiplicando-os indefinidamente.

Na primeira utilização a vontade de exceder foi automática, mas o improviso foi profícuo pela falta de repertório técnico, por mais que desejasse uma unificação com minha cabeça eletrônica, os meus gestos não se amplificavam no espaço, e o excesso da minha criação corporal monstruosa beirou o caótico. Na segunda tentativa, tecnicamente munido de conhecimentos corporais, o excesso não foi abolido, mas reorganizado em potencial cênico, gestualmente disforme, mas condizente com o jogo proposto. A vontade de exceder limites foi tecnicamente filtrada, sem consumir muita energia, mas intensificada através de um corpo extracotidiano, um corpo grotesco, mediante uma dualidade auto-representativa entre corpo e imagem. A monstro-máscara de Donasci

${ }^{31}$ Estas vídeocriaturas utilizam monitores preto e branco (como proposta de linguagem) desde 5 polegadas (VideoFantoche, a esquerda na mão do performer), até o protótipo de 24 polegadas com dois performers (penúltimo da esquerda para direita). 
desmascara em cena o homem produto da ciência, produto da sociedade prometeica, que necessita da técnica para exercer cada vez mais o melhor desempenho corporal em sua forma ciborgue. Deste modo, a pluralidade técnica aliada às novas mídias gera uma autorreflexão, uma necessidade humana de coexistência simbiótica. Isto engendra novas formulações, proporcionando uma inovação para o desenvolvimento artístico, onde a presença do performer a partir de mutações do ator estabelece uma paisagem multiforme criada pela ideia do "videoteatro" ou mesmo como artefato pedagógico no treinamento do ator.

A monstro-máscara videográfica necessita que o ator, principalmente o que representa o seu rosto, tenha um eixo de interpretação: o rosto mexe, mas a cabeça não. Ao passo que uma videocriatura como Videofantoche (1984) requer não só a técnica de manipulação de bonecos, mas necessita de uma ternária concentração do performer que veste o "corpo": 1. Deve ter atenção do próprio corpo no espaço; 2. Estar concentrado com o sincronismo de sua cabeça eletrônica; e 3. Precisa animar, dar vida ao boneco em suas mãos.

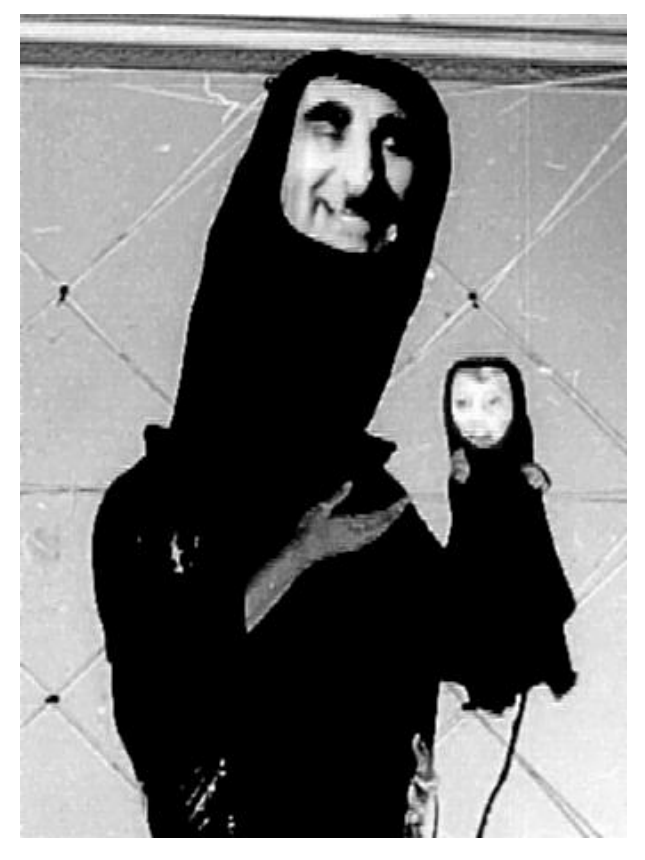

Figura 32 - Videocriatura e Videofantoche 
Desta forma, a atuação do performer que representa simultaneamente dois personagens torna-se complexa, uma vez que ele precisa interpretar dois personagens distintos simultaneamente. Exige neste caso um conhecimento apurado não só das particularidades da arte da animação, mas também das particularidades da interpretação do chamado "teatro de atores". Além disso, em monstro-máscaras como a PlasmaCriatura (2002) é preciso uma condição energética e física para aguentar o peso da tela de plasma de 42 polegadas. Nesta videoperformance um personagem pré-gravado de torso nu apresenta-se com atitudes cheias de tensão física e emocional. Em determinado momento encontra-se imerso em uma banheira/piscina. Neste meio tempo, ao som de um tango, dança ao vivo com as pessoas presentes. A conexão físico-energética é fundamental. "É o que vai dar vida às ações físicas, transformando-as em ações vivas e a técnica em técnica-em-vida"(BURNIER, 2009, pág.55). O performer então assume uma corporeidade que intervém no espaço e no tempo, transformando-se num individuo atuante que garante presença criativa à videocriatura.

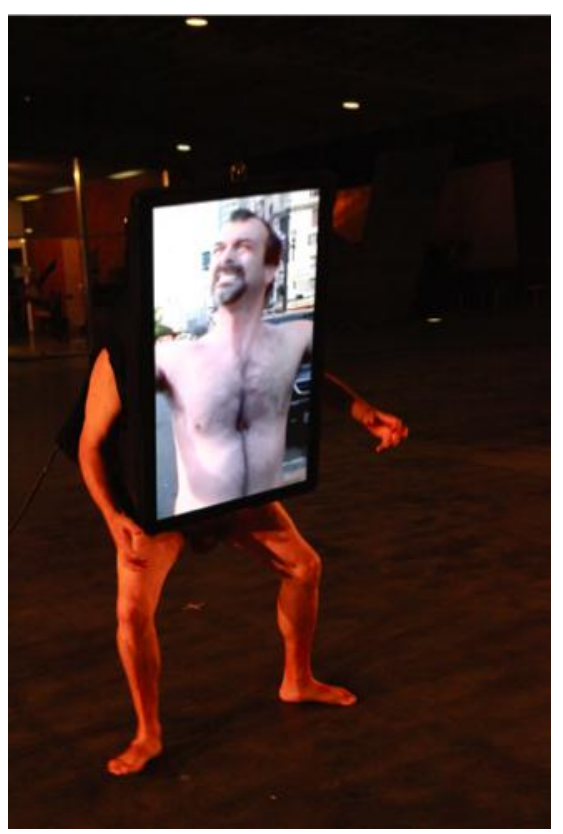

Figura 33 - Videotango no circuito Bodearte -2012 


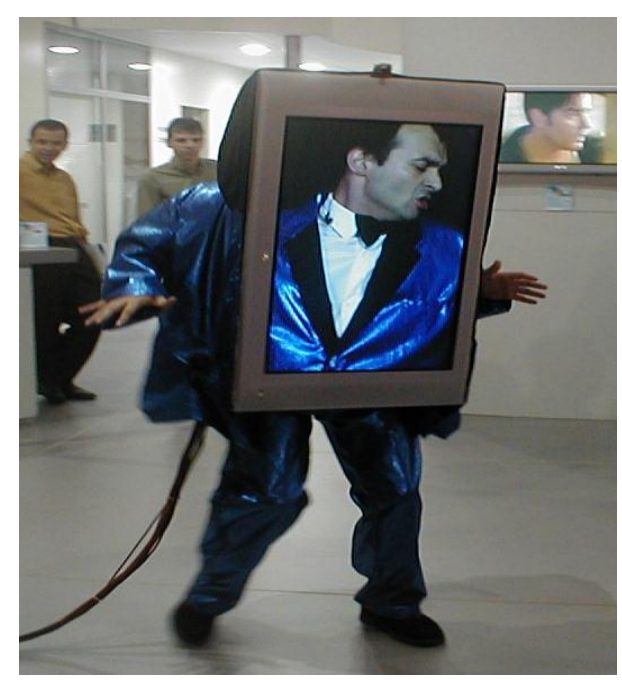

Figura 34 - PlasmaCriatura - videocriatura com rosto e parte do corpo de monitor de plasma de 42 polegadas. $^{32}$

Nesta presença performática acentua-se a característica mais preponderante presente nas monstro-máscaras de Donasci: o acaso. Lidar com as situações de improviso em cena requer dos performers tanto do rosto como do corpo uma atitude de escuta das reações do público. Quando o ator abre-se ao desconhecido, quando trabalha além de um plano intelectual, a resposta à experiência concretiza-se em um nível intuitivo, no aqui e agora. Isto gera espontaneidade na hora de atuar e nas inter-relações com o mundo a nossa volta que está em constante transformação.

A monstro-máscara é um ser técnico e requer algumas regras tanto para quem atua através do monitor, quanto para o corpo presencial. Para o ator que configura a cabeça há uma necessidade de entendimento que o eixo de movimentação deve ser restrito ao recorte do vídeo, de angulação lateral, inclinação e rotação. "Existe toda uma técnica de olhar, de eixo de interpretação, onde o rosto mexe; a cabeça não",33. Além do que, Donasci pondera que o ator que configura o corpo da monstro-máscara deve evitar o "overacting", termo tipicamente pejorativo para descrever o desempenho exagerado, usado como auxílio cômico ou para realçar características marcantes. O

\footnotetext{
${ }^{32}$ A videocriatura está ligada por cabos a um estúdio móvel. Um ator (imagem) que aparece no plasma interpreta ao vivo as ações, que é transmitido para o plasma instalado em outro performer. A interação do plasma gera uma interação mais forte. Microcâmera e monitores internos na videocriatura permitem a visualização do público pelo performer.

${ }^{33}$ Entrevista pessoal realizada em 2014 com Otávio Donasci.
} 
performer que empresta seu corpo a monstro-máscara, pelo excesso gestual, que acentua o que está sendo dito por sua cabeça eletrônica cria ruído, suja a atuação da videocriatura. Entretanto, o excesso é típico do monstro, sua diferença persiste exatamente na amplitude, na visão arrebatadora através do olhar que ele causa. Como também, a união de dois meios, do quente (corpo) com o frio (vídeo) corrobora a linguagem da máscara quando o ator necessita “apagar" o ego para o atuar mascarado.

Em uma de suas primeiras criações chamada Profeta, realizada em 1981 na Galeria São Paulo, Donasci e o ator Osmar de Pieri, um dos primeiros a utilizar as monstro-máscaras videográficas, passaram horas testando vários materiais e figurinos. Juntos criaram um laboratório de utilização que aos poucos amplia as possibilidades cênicas da videocriatura. "Perguntava para ele (di Pieri) o que você tem na cabeça, ele dizia: tenho tal texto, então eu dizia a ele para deixar o texto fluir. Ele trabalhava o texto da primeira vez normal, depois laboratizava o processo, esticando as frases, falando vagarosamente, com um tom acima" ${ }^{34}$. Enquanto o texto tomava forma, Donasci interferia em seu rosto como um cientista, forjando as possibilidades criativas do meio eletrônico, unindo corpo e imagem de seu prometeu videográfico. Este trabalho experimental constante demonstra como a monstro-máscara requer um trabalho minucioso como aborda COHEN (2004) na preparação do ator-performer em quatro níveis:

- Laboratório de vídeo e expressão facial - fase de preparação do ator para ter sua imagem gravada.

- Laboratório de criação de protótipos como monitores-fase, onde são criados os "seres" (criaturas antropomórficas, formas de animais etc.).

- Laboratório de expressão corporal com protótipos-treinamento do performer que fará o "corpo". Gestualidade e sincronicidade com a imagem do "rosto".

- Laboratório de utilização do espaço cênico para o espetáculo-treino do uso, do espaço e do contato do público.

34 Ibid. 


\subsection{3 - Videocriaturas prometeicas.}

Não choreis prematuramente; esperai até que tenhais de tudo pleno conhecimento.

Prometeu Acorrentado - Ésquilo.

Conforme SANTAELLA (1997) máquinas sensórias funcionam como extensões dos nossos sentidos, dotadas de conhecimento sensível. A monstro-máscara de Donasci amplifica a produção de signos: imagens e sons que captam e reproduzem tais signos roubados do mundo real. Ou seja, estas máquinas sensórias capturam a realidade para dentro de uma câmera ou gravador e o devolvem para o mundo como um duplo, eco daquilo que já pré-existe numa existência duplamente doadora e usurpadora.

Por tal motivo, a relação das máquinas sensórias desloca-se quase que por completo da relação dos aparatos com o ser humano para obsessão nas relações que os signos estabelecem com a realidade como fidelidade, infidelidade, imitação, simulacro, verossimilhança. Para FLUSSER (1985) a imagem técnica transcodifica o recorte de uma realidade e, "como toda a imagem, é também mágica, seu espectador tende a projetar esta visão sobre o mundo".(pág.11). Vivemos assim, uma ritualização, vivenciamos, produzimos, valorizamos e agimos cada vez mais em função das imagens. Enquanto a magia pré-histórica ritualiza determinados modelos, mitos, com o intuito de transformação do ser, a imagem técnica ritualiza outro tipo de modelo: o "programa". A nova magia visa readequar seus receptores para um comportamento mágico programado. A função das imagens técnicas é a de emancipar a sociedade da necessidade de pensar conceitualmente.

O caráter aparentemente não-simbólico, objetivo, imagens técnicas faz com que seu observador as olhe como se fossem janelas e não imagens. O observador confia nas imagens técnicas tanto quanto confia em seus próprios olhos. Quando critica as imagens técnicas (se é que as critica), não o faz enquanto imagens, mas enquanto visões do mundo. (FLUSSER, 1985, PÁG. 10). 
Se a fotografia confere uma máscara fiel aos fatos deve-se ao seu papel de informação e desinformação, sua capacidade de emocionar, transformar, denunciar e manipular os fatos, devido ao seu status de elemento documental das ciências positivas do século XIX. É um instrumento ambíguo de conhecimento que ganha força como representação iconográfica de um dado real, por ser considerada desde seu advento como registro objetivo, "neutro", produto de um objeto técnico "que não pode mentir", um duplo da realidade, um objeto de registro mimético.

A imagem fotográfica é "[...] um complexo e fascinante processo de construção de realidades" (KOSSOY, 2002, pág.47). Processos ideologizantes de manipulação da opinião pública. O fotógrafo constrói o signo, a representação e nosso imaginário reage diante das imagens técnicas de acordo com nossas concepções, situação econômica, social e política. A realidade da fotografia é fixa e imutável, refere-se ao recorte temporal, refere-se à realidade do assunto, mas também é o registro criativo que vira documento de múltiplas interpretações.

Por outro lado, a imagem do vídeo é uma imagem-movimento, eletrônica, o ato do olhar, um ato de todos os corpos de imagens existentes. Vídeo em latim não é só um verbo, como também é um verbo na primeira pessoa do singular do indicativo do verbo ver: "eu vejo". De outra maneira, o vídeo é o ato de olhar num "aqui e agora" de um sujeito em ação, o que acarreta um processo em curso e uma adequação temporal ao presente histórico. O "eu vejo" é algo ao vivo, no presente diferente do ver "saudosista", preso ao passado da fotografia. O vídeo figura como uma perspectiva ambígua, onde é objeto e processo, imagem-obra e meio de transmissão. É paradoxalmente bifronte.

A linguagem do vídeo mascara e deforma. Nesta mistura, neste trânsito entre linguagens, imprime uma estética do desvio, do disforme, "que evoca a construção de um mundo perceptivo, ordenado, homogêneo [...] a construção de um mundo híbrido, heterogêneo, impuro, repleto de conflitos e ruídos." (MELLO, 2008, pág.124). É a desconstrução como procedimento das imagens de síntese numérica com seu excesso de limpeza, estilização que tornam as ações matematicamente perfeitas. $\mathrm{O}$ vídeo reorganiza nosso determinismo tecnológico ao inserir experiências "sujas", rasuradas e transmutantes entre corpo e imagem. 

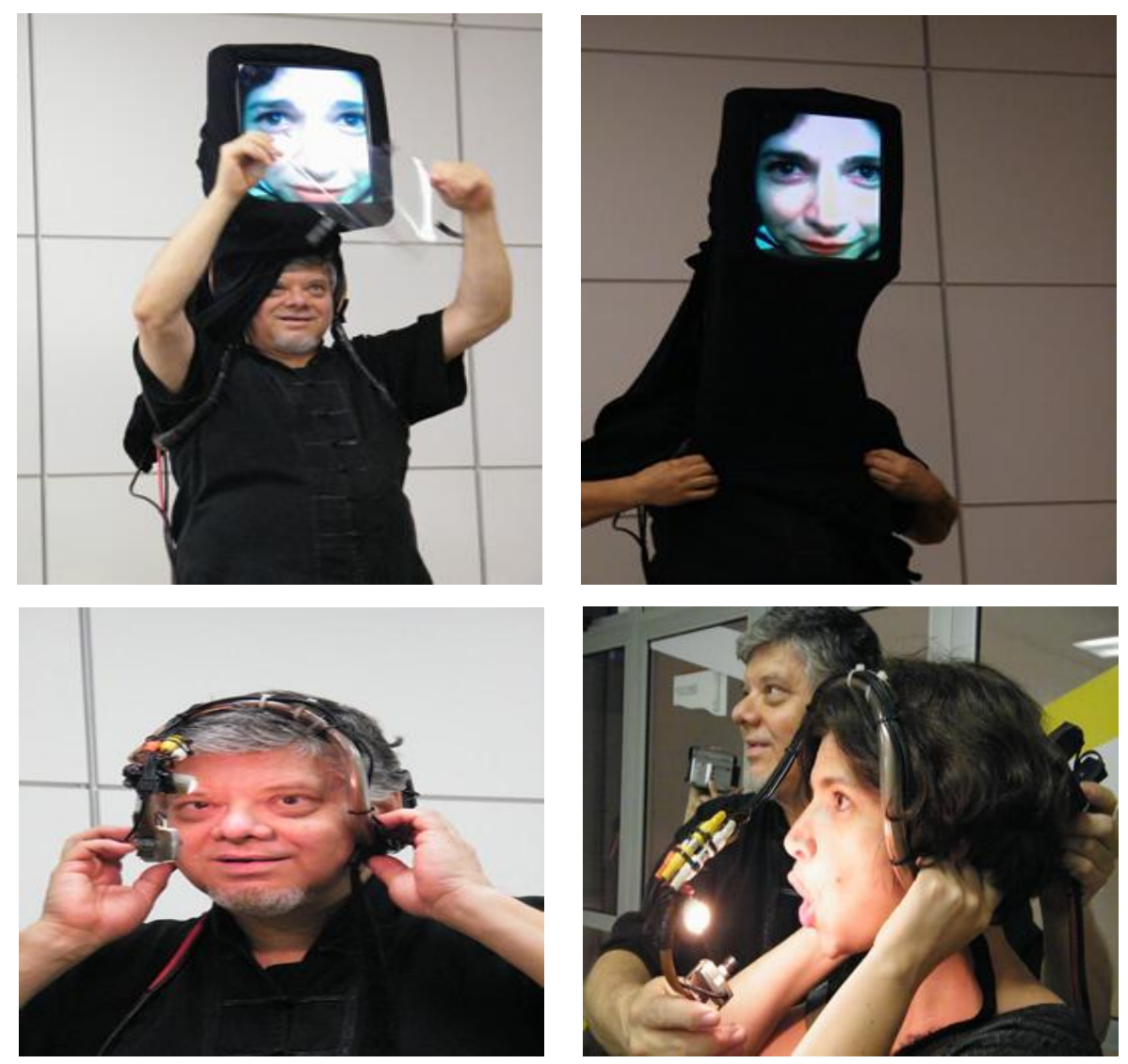

Figuras 35, 36, 37 e 38 - Donasci demonstrando a utilização da videocriatura. ${ }^{35}$

O disforme propaga-se pela baixa definição do vídeo que opera com pontos de informação. MACHADO (1995) afirma que a tela do cinema é transparente e desta forma torna-se invisível ao espectador, o que garante uma representação realista e força o espectador a se identificar com a imagem projetada. Entretanto, na tela do vídeo existe uma opacidade, de modo que o espectador ao contemplá-la depara-se com sua materialidade. Sistemas com baixa definição aguçam a imaginação ao mesmo tempo em que exigem do espectador uma maior participação. $O$ poder imagético das videocriaturas, da interação, de sua imprevisibilidade se deve pelo fato da imagem videográfica ter um recorte fechado e sempre em primeiro plano. "Um plano geral, excessivamente aberto, não é considerado uma boa imagem de vídeo, porque tende a desmaterializar as figuras que estão representadas" (MACHADO. 1992/1993, pág.8). O vídeo como um meio híbrido, opera com códigos distintos - parte importado do cinema e parte do teatro, da literatura, do rádio e mais modernamente da computação gráfica, aos quais acrescenta recursos expressivos específicos, alguns modos de formar

\footnotetext{
${ }^{35}$ Instante - Experiência / Acontecimento em Arte e Tecnologia no SESC - Campinas, São Paulo (2011).
} 
ideias ou sensações. O discurso videográfico é impuro por natureza, ele reprocessa formas de expressão, atribuindo-lhes novos valores, e sua essência encontra-se sobretudo, na solução peculiar que ele dá ao problema de síntese de todas estas contribuições.

Em seu videoteatro performativo, com características pós-dramáticas, Donasci explora estruturas audiovisuais elaboradas, alargando os processos no espaço e no tempo. A instantaneidade e simultaneidade da monstro-máscara videográfica não se limitam a apresentar o resultado final, mas passam a enriquecer o processo de constituição da imagem como procedimento teatral. Cabe ao espectador agora, reagir diante do que vê e não apenas contemplar uma imagem pacientemente reproduzida. $\mathrm{O}$ que está em cena não é o personagem, mas a máscara provocadora duplicada do homem prometeico. E nesta provocação performativa, Donasci nos oferece um ritual mascarado como nas sociedades antigas. A única diferença é que a monstro-máscara não representa um deus, mas o homem em simbiose com a máquina.

\footnotetext{
Com o que será parecido o homem do futuro? Há séculos que biólogos, futurólogos, escritores de ficção científica se entregam a este perigoso exercício [...]. Uma enorme cabeça e pernas minúsculas [...] a emergência da biótica deixa augurar interfaces ainda mais íntimas entre o homem e suas máquinas, levando, inclusive, à criação de novos órgãos e novos sentidos. (ROSNAY, 1997, pág. 156-157).
}

Esta simbiose intersubjetiva coloca em jogo os corpos em interação e a relação do teatro e mídia. LEHMANN (2007) afirma que o rosto dos atores ampliados por uma imagem eletrônica, altera a realidade teatral de maneira fundamental pela adição de recursos e esta imagem de vídeo numa relação de complexidade com o corpo revela uma estética midiática em cena. Em tal atitude pode-se ver as máscaras de comportamentos vigentes dentro de uma sociedade tecnocrata, que direcionam a percepção corporal como um ser expandido. Nesta ode a comutação, o público assiste a um agenciamento rápido, codificado numa mistura heterogênea de partes do corpo, 
sons, imagens de vídeo, monitores, bi e tridimensionalidade como mimese da realidade da sociedade técnica.

A performatividade da monstro-máscara videográfica trabalha com esta variedade de códigos, ao mesmo tempo móveis e de constante mutabilidade que determinam na sua interação possibilidades combinatórias gestuais e de comportamento. Perpetua desta forma um processo de engajamento da arte que se dá tanto à sua criação e envolvimento com signos abertos, quanto criar para si seu próprio espaço de autoliberação.

Em seus 30 anos de existência, as monstro-máscaras videográficas ainda suscitam estranhamento a quem as observa pela primeira vez. Causam deslumbramento, fascinação, empatia. Elas dançam, cantam, duplicam-se, interagem com as pessoas, andam a cavalo, namoram, xingam, misturam-se com outros objetos e nos fazem rir proporcionando a ritualização da cena, onde o que importa não é o que está sendo narrado, mas a prática, o acontecimento em si. No videoteatro de Donasci existe uma combinação de formalismo e espontaneidade. Textos e imagens pré-gravados convivem com as situações de improviso, por intermédio de um discurso que não se dá pelo verbal, como no teatro engajado de vanguarda, mas como metáfora visual de um tempo prometeicamente projetado.

Se o meio eletrônico manipula o real, criando padrões, mitos, máscaras, monstros que passam a ser aceitos como verdade, Donasci usa a mesma arma para denunciar os ideais da sociedade prometeica onde os homens se transformam naquilo que contemplam. Assim, utilizamos ou percebemos uma extensão de nós mesmos sob a forma tecnológica, implicando necessariamente em adotá-la. Ai aparece o "princípio do embotamento", quando temos de entorpecer nosso sistema nervoso central, expondo-o e projetando-o para fora, de forma que a tecnologia seja uma extensão do nosso corpo físico. Pois de acordo com essa visão, os artefatos técnicos constituem meras extensões, projeções e amplificações das capacidades próprias do corpo humano. As monstromáscaras videográficas apresentam aspectos prometeicos por certo "aperfeiçoamento" do corpo, de forma naturalista e não-transcendentalista; ou seja, não pretende ir além dos limites impostos pela natureza humana, mas pretende-se um upgrade corporal, uma simbiose. 
Donasci ao criar uma infinidade de monstro-máscaras abre uma discussão sobre os limites deste conhecimento, antecipa as transgressões de fronteiras abstratas ou concretas, de códigos e aspirações. Mais do que fomentar se o ator de carne e osso é realmente necessário, se pode ser substituído, melhorado, hibridizado, ele expõe o desejo emancipatório do homem prometeico de se autofundir, de controlar a natureza. Sua obra amplia a estética teatral ao promover um debate do corpo e dos objetos, a fronteira entre o humano e o inumano. Para LYOTARD (1990) o mundo tecnocientífico pós-industrial tem por princípio representar, legitimar tudo numa mesma superfície, produzir cultura e mercado. Para ele o papel dos artistas não é recompor uma realidade através do conhecimento técnico, mas fazer "alusão a algo não apresentável, o que não tem nada de edificante, mas se inscreve no infinito da transformação das realidades" (pág.131). A função então seria construir a cada ciclo uma nova versão, mais crível, durante um espaço de tempo que por sua vez figuraria como a concepção humana idealizada. Sua criação perpassou fronteiras: teatro, performance, circo, música, dublagem, televisão e os mais variados campos artísticos. Seja videoteatro ou videoperfomance, Donasci proporciona uma elevada discussão sobre o hibridismo e os sistemas de controle pelo qual todos nós estamos sujeitos. Desvela a crença do serhumano na ciência através da técnica como processo irreversível, além expor um mundo fragmentado, multifacetado, onde talvez o único meio de trocar experiências seja rearranjar o "eu vejo" para “o que eu quero?”.

\section{5 - Sociedade fáustica}

É inegável que a sociedade mata o desejo.

Fausto, Goethe.

A imagem mais preponderantemente fáustica é a dependência conceitual e ontológica da ciência em relação à técnica. A priori, a ciência deve servir sempre a um saber tecnológico. Pressupõe a prioridade ontológica da técnica sobre a ciência, onde os 
procedimentos científicos não visam a verdade ou o conhecimento da natureza íntima (os poderes causais) das coisas, mas tão só a cabal compreensão dos fenômenos, estritamente para fins de previsão e controle. É a procura pela apropriação total da natureza, tanto exterior quanto interior do corpo humano. A primeira formulação geral de uma visão fáustica da técnica e da ciência foi em 1918, na obra A Decadência do Ocidente, de Oswald Spengler, que causou muita polêmica pelo fato de coincidir intencionalmente com o lapso industrial e militar da Alemanha e pela passagem da República de Weimar ao Terceiro Reich.

Em sua ideologia as aspirações de poder e do conhecimento são a mesma do personagem Fausto, mito do homem contemporâneo, símbolo da insatisfação e da impermanência que o faz buscar um sentido, um valor. É a sede do infinito, do ilimitado, do mais além. É a busca incessante pelo novo, a inquietação que jamais cessa, num ímpeto para se embrenhar no desconhecido, a inesgotável ânsia do saber e da transformação. Fausto escapa ao mundo da ética. Quer ir adiante, seja para onde for independentemente do bem ou do mal. Quer desvendar o universo a qualquer custo. "Prometeu desafiou um deus. Fausto quer ser Deus. Animado por uma vontade de crescimento infinito, pelo desejo de superar as suas próprias possibilidades" (SIBILIA, 2003, pág. 43). A vontade de tomar as rédeas do destino e o controle interior e exterior da vida.

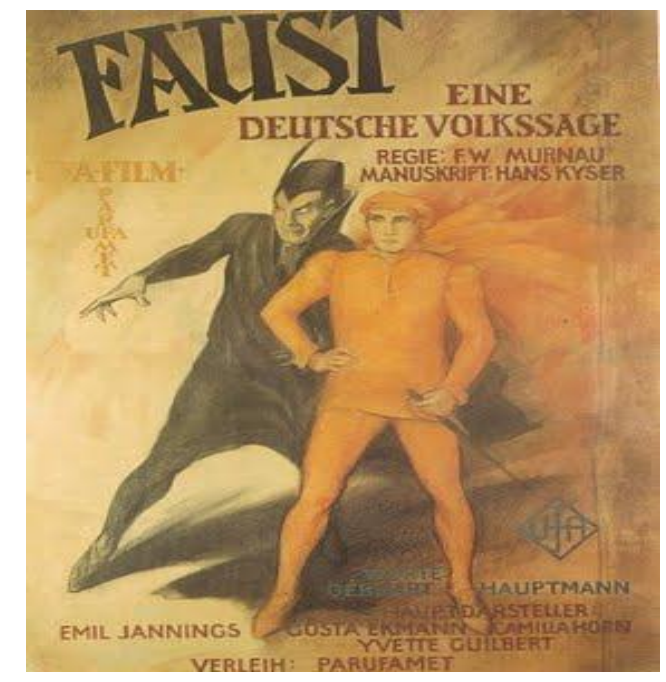

Figura 39 - Fausto (Alemanha - 1926) Filme de F.W. Murnau. 
A conquista exterior é impulsionada pela teleinformática, pelos computadores, telefonia móvel, as redes de comunicação, os satélites e toda miríade de gadgets teleinformáticos que abarrotam os mercados, contribuindo para a produção de corpos e das subjetividades do século XXI. Neste mundo cada vez mais computacional geram pensamentos de transfiguração virtual, criando pesquisas que tem como objetivo transpor o espírito para uma máquina, com a desencarnação da mente que abandona o corpo para se reinteirar aos fluxos informáticos. Na bioinformática, através da inteligência artificial, os pesquisadores pretendem fazer a transferência da consciência humana para um computador. Hans Moravec, do Instituto de Robótica da Carmegie Mellon University, de Pittsburgh, afirma que a partir de 2040 os computadores adquirirão as potencialidades do cérebro humano. Entre outras palavras, o robô como o idealizamos, mimeticamente intrínseco ao humano, só pode ser viável quando o computador atingir uma potência pelo menos igual a um milhão de vezes a potência de um PC atual, igualando-se à potência do cérebro humano. "O objetivo inicial $d a$ robótica será portanto, atingido: uma máquina se deslocará livremente, totalmente dotada das capacidades intelectuais de um ser humano!" (LECOURT. 2005, pág. 56).

O projeto fáustico volta-se também para o interior do corpo, através da biotecnologia, com a tecnociência contemporânea que deseja a transposição de nossas limitações biológicas, potencialidades e desejos de existência. O conhecimento científico é colocado à disposição de uma reconfiguração do que é vivo contra o envelhecimento e a morte. "Os avanços mais recentes na área da biotecnologia, com toda sua artilharia informática a serviço do "deciframento da vida", se propõem precisamente a vencer as resistências que esse derradeiro vestígio de caráter sagrado da natureza costumava opor ao instrumental tecnocientífico. Cedendo por fim, a última terra incógnita do planeta Terra já pode ser conquistada: o mistério da vida" (SIBILIA. 2003, pág.47). As descobertas da biotecnologia não almejam meras melhorias cosméticas em nossos corpos, redefinindo a antiga e conhecida evolução orgânica pelo tecnológico no tratar os seres naturais como matéria-prima manipulável. A ideia é a supressão total dos defeitos congênitos antes da concepção e posteriormente a conquista da imortalidade. 
O Projeto Genoma, financiado por agências governamentais americanas e anelado também pelo capital privado tem como finalidade a manipulação genética do DNA da espécie humana, com a intenção de detectar a origem das doenças e evitá-las antes que elas aconteçam (até mesmo antes do nascimento). Segundo LE BRETON (2003) a decodificação do genoma provoca uma série de conflitos de interesses, principalmente no que se refere a todo comportamento programado, subscrevendo sem compaixão o indivíduo ao seu destino.

A fantasia da onipotência do gene o tornou um ícone cultural, um equivalente leigo da concepção da alma no cristianismo. Discute-se o gene da resistência física, da preguiça, da celebridade, do sucesso, da felicidade, da propensão às drogas etc., favorecendo a crença que a genética é a resposta para todas as questões. O DNA então seria a projeção biológica, a transparência do sujeito, uma revelação de seu destino préprogramado. “Os videntes ficam sem emprego a partir destes fatos - os biólogos dirão o futuro do indivíduo, suas probabilidades de carreira, seus gostos sexuais, suas chances de ser bem sucedido na vida, sua inteligência [...]”' (LE BRETON, 2003, pág.108).

A correlação entre os dois pensamentos, o prometeico e o fáustico, pode também ser observada pela passagem do mundo analógico-mecânico para informático-digital, ou seja, das sociedades disciplinares (prometeicas) para as sociedades de controle (fáusticas). Em um artigo, Gilles Delleuze, com base na teoria dos corpos dóceis de Foucault, afirma que as sociedades disciplinares nos séculos XVIII e XIX atingem seu apogeu no início do século XX e procedem à organização dos grandes meios de confinamento. O indivíduo não cessa de passar de um espaço fechado a outro, cada um com suas leis: primeiro a família, depois a escola ("você não está mais na sua família"), depois a caserna ("você não está mais na escola"), depois a fábrica, de vez em quando o hospital, eventualmente a prisão, que é o meio de confinamento por excelência. É a prisão que serve de modelo analógico ${ }^{36}$. Mas tal sociedade conheceria sua crise devido às transformações iniciadas com a Segunda Guerra Mundial.

Ao contrário das sociedades disciplinares que operam num sistema fechado dentro das instituições de confinamento (a escola, a fábrica, o quartel e o hospital), os

\footnotetext{
${ }^{36}$ Gilles Deleuze- Post-Scriptum Sobre As Sociedades De Controle. Conversações: 1972-1990. Rio de Janeiro: Ed. 34, 1992, p. 219-226. Tradução de Peter PálPelbart.
} 
diferentes internatos ou meios de confinamento pelos quais o indivíduo transita são variáveis independentes: supõe-se que a cada vez ele recomece do zero e a linguagem comum a todos esses meios é analógica. Nas sociedades de controle os estados são metaestáveis, onde tudo é variável. Ao passo que os diferentes modos de controle, os controlatos, são variações inseparáveis, formando um sistema de geometria cuja linguagem é numérica (o que não quer dizer necessariamente binária). Os confinamentos são moldes, distintas moldagens, mas os controles são modulações autodeformantes que mudam continuamente, a cada instante.

É fácil fazer corresponder a cada sociedade certos tipos de máquina, não porque as máquinas sejam determinantes, mas porque elas exprimem as formas sociais capazes de lhes darem nascimento e utilizá-las. As antigas sociedades de soberania manejavam máquinas simples, alavancas, roldanas, relógios; mas as sociedades disciplinares recentes tinham por equipamento máquinas energéticas, com o perigo passivo da entropia e o perigo ativo da sabotagem; as sociedades de controle operam por máquinas de uma terceira espécie, máquinas de informática e computadores (FOUCAULT. 2008, pág. 223).

A tecnologia e ciência constituem os mais derradeiros e significativos capítulos da história humana. Nesta perspectiva, a técnica não se origina de uma racionalidade cognitiva anterior e sim, da vontade de uma cultura, a vontade de poder. A biopolítica iniciada com os nazistas devido a sua eutanásia compulsiva surge agora com outro discurso, com outras proporções, devido ao surgimento da manipulação genética, que amplifica as possibilidades de transformação dos seres humanos.

Segundo Baudelaire se o artista comparado ao público para Baudelaire é um relógio que adianta, respondendo à manipulação pela imaginação, Denis Marleau possibilita uma leitura desta corrente de pensamento, de exposição da técnica como formação de um imenso corpo institucionalizado, submisso ao Estado e ao mercado. A obra videográfica de Marleau revela o que deve ser revelado, mostra as possibilidades transumanas. Suas monstro-máscaras inserem o numérico como relação intrínseca entre homem e a máquina. Busca o eterno retorno nas leituras possíveis de um futuro que se configura no horizonte, na exposição das interfaces que facultam ao corpo uma virtualidade. 


\section{6 - Denis Marleau - a pele como simulacro}

Denis Marleau é um dos mais importantes encenadores canadenses de sua geração, com mais de 30 anos de atividade e 40 espetáculos em seu currículo, com produções relevantes no exterior que trabalham tanto a primazia do texto quanto a tecnologia videográfica. Nascido em Valleyfield, no Quebec, estudou no Conservatório de Arte de Montreal onde descobriu seu talento como encenador devido ao seu interesse pelas cores, formas e cenografia. Após sua formação, parte para a França para realizar um estágio de mímica corporal dramática durante dois anos, ao mesmo tempo que tem contato com diretores importantes como Tadeusz Kantor, Giorgio Strehler e inúmeros e diferenciados repertórios teatrais.

Sua experiência internacional possibilita reorganizar algumas crenças e ideologias que trouxe de sua formação. Em 1982, três anos depois de seu retorno ao Canadá, funda o UBU Compagnie de Création e, como diretor geral, artístico e cenógrafo, começa sua carreira com espetáculos-colagem concebidos a partir de textos dadaístas. A colagem que Marleau realiza é um jogo de materialidade sonora, que a partir do eixo metáfora/metonímia determina o movimento de aproximação ou afastamentos dos fragmentos selecionados. Desenvolve um método com base no trabalho vocal que não enfatiza a textualidade e se concentra na poesia sonora e na abordagem virtuosa do ator. Espetáculos como Merz Opéra (1987), Oulipo Show (1988) e Les UBS (1991) revelam um diretor com uma visão teatral única, especialmente em Quebec, onde o tradicionalismo e realismo dominam. Em seu país, sua geração mudou radicalmente a ideologia da estética teatral a partir de 1980, e isto se deve aos jovens diretores que encenam os clássicos com uma roupagem coerente com o seu tempo e com a compreensão de sua época. Basicamente tais encenadores utilizam belas imagens estéticas; outros edificam a capacidade poética da obra e corporal dos atores; e ainda, outros abordam os clássicos com a firme intenção da primazia das palavras, da exploração de sua sonoridade. Neste último exemplo encontramos Marleau, que monta os clássicos como autores modernos e monta os autores modernos como clássicos. Marleau se encontra entre os revitalizadores do teatro canadense, que a partir de 1980 
oscilaram entre a criação de peças de repertório com um diálogo universal e de renovação clássica.

A partir de 1990 sua atuação eclética o leva a novas dimensões com espetáculos que revisitam mestres como UBU (Alfred Jarry), Roberto Zucco (Bernard-Marie Koltès) e Woyzcek (Georg Büchner), além de abordar novos dramaturgos: Normand Chaurette, José Pliya, Gaétan Soucy, Jon Fosse e peças de repertório: Lessing, Goethe, Beckett, Shakespeare, entre outros.

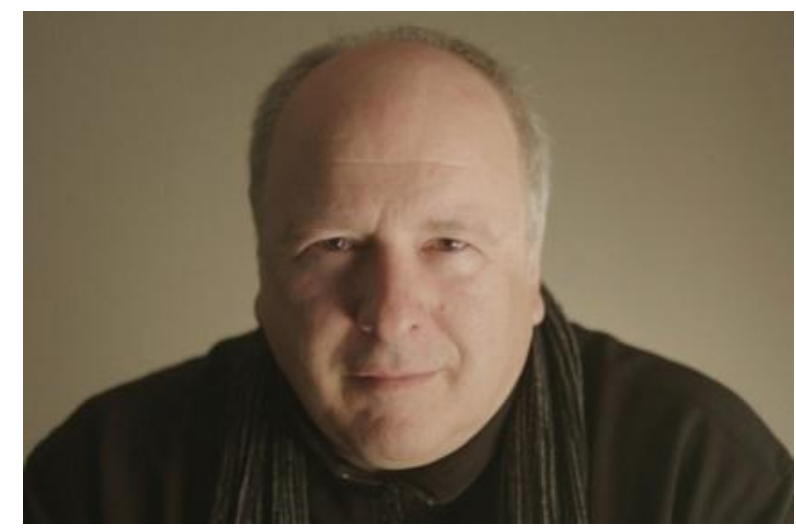

Figura 40 - Denis Marleau.

Marleau tem a difícil tarefa de explorar o texto de forma espetacular (opsis) ou produzir/criar todos os elementos cênicos com uma coerência formal rigorosa, aproximando-se de um visual emprestado à arte contemporânea, além de primar por um trabalho vocal rítmico, gestual não-realista e de poesia formalista. Explora uma estética pós-dramática com presença, readmissão e a continuidade transformada de estéticas de vanguarda. Utiliza uma peça-paisagem, que se refere a outro tempo, que exige esforço contínuo de observação, com uma tensão que privilegia uma "atmosfera" reflexiva, que desta forma o aproxima dos simbolistas como Maeterlinck, Jarry, além de Craig, Kantor e contemporaneamente, de Robert Wilson.

A partir de 1997, Marleau começa uma segunda fase criativa e trabalha com artistas das mais variadas disciplinas, em especial o escultor Michel Goulet. Nesta etapa começa a fazer experimentações videográficas que suscitam velhos questionamentos sobre a presença do ator em cena com espetáculos como Les trois jours derniers de 
Fernando Pessoa (1997), Les Aveugles (2002), Dors mom petit enfant (2004), Une fête pour Bóris (2009) e Agamennon (2011). Em tais espetáculos explora hibridismos com a escultura, a música, a dança, as artes visuais e as novas tecnologias. Por mais de 20 anos, Denis Marleau oferece uma reflexão sobre a inserção de novos suportes midiáticos em cena e fomenta o debate sobre a virtualização do ator.

Nos cinco espetáculos acima citados Marleau esboça interesse pela duplicação de personagens e pode-se se dizer até com certa obsessão, um estilo. Na concepção do espetáculo, Marleau torna-se de certa forma um cineasta, isolando as imagens do rosto dos atores com o objetivo de capturar em grande plano expressões frontais, petrificadas como a potência da Górgona, que hipnotizam o espectador pelo olhar. São personagenscoro, são esboços de homens e mulheres, lembranças de seres desaparecidos, de dimensão estática, uma zona intermediária entre a vida e a morte, território tão tipicamente aludido à máscara. A atmosfera criada reforça a experiência coletiva, ao mesmo tempo individual da perda, da vertigem, da solidão e do questionamento fundamental de qualquer ser humano em relação ao seu lugar no mundo.

\subsection{1 - Marionetização da cena}

Em sua fase de experimentação videográfica, todo o mise-en-scène de Denis Marleau mescla corpos e imagens, numa ação virtualizada que projeta o rosto de atores em máscaras brancas utilizadas por outros atores em cena, ou moldes de cabeças presos em suportes ou em bonecos. No espetáculo Les trois jours derniers de Fernando Pessoa, baseada na obra literária do italiano Antonio Tabucchi, mostra o poeta português Fernando Pessoa hospitalizado devido a uma crise hepática grave. Três dias depois, recebe visitas noturnas de seus principais heterônimos: Álvaro de Campos, Alberto Caeiro, Ricardo Reis, Bernardo Soares e Antônio Moura. Dividido em cinco atos, cada heterônimo vem acertar as contas com o seu criador em cenas que quebram as fronteiras do sonho e da realidade, instaurando-se uma convergência entre atores e objetos, entre a vida e a morte. A utilização do vídeo desenvolve o mundo interior de Pessoa, um sentimento nostálgico do personagem materializado por seus heterônimos. 


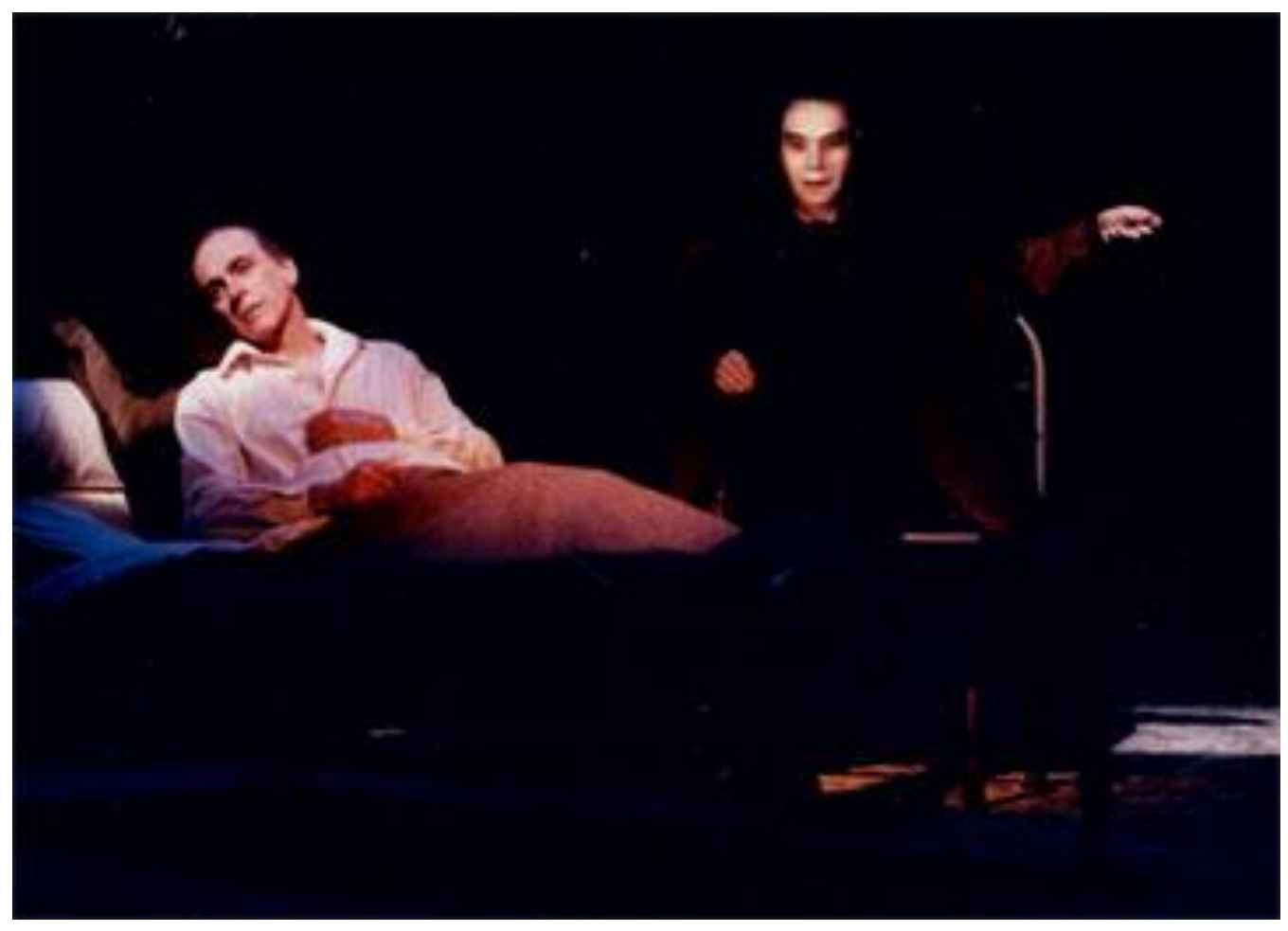

Figura 41 - Le trois derniers jours de Fernando Pessoa - 1997.

Para se atingir esta atmosfera, na etapa de pré-produção, Marleau capta em vídeo, em close-up filmados em longos planos-sequência, o rosto e as falas para cada personagem. Para isso, o ator deve evitar qualquer movimentação exagerada, seu rosto deve ficar num eixo frontal, imóvel, deve caber num espaço estático de interpretação. Conjuntamente a esta etapa são confeccionadas máscaras brancas, como máscaras mortuárias, tirando o molde em gesso da cabeça do ator. Posteriormente, na fase de encenação, a imagem capturada do ator é projetada sobre as máscaras brancas, que podem estar tanto no rosto de outro ator como em cabeças brancas fixas em suportes. 


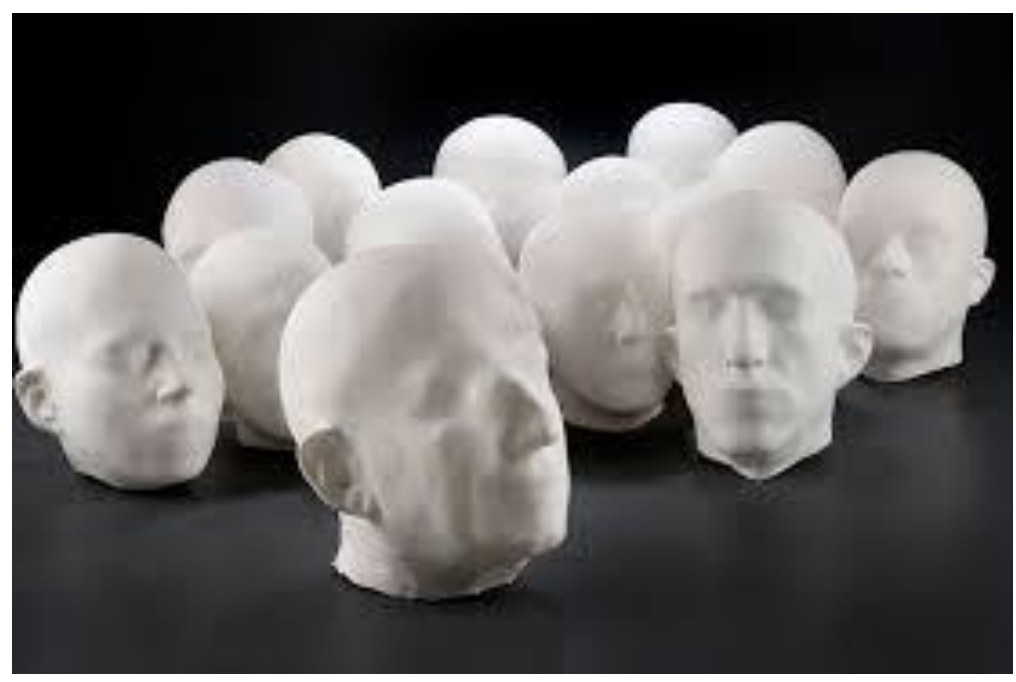

Figura 42 - exemplo de moldes - Cabeças em gesso para exposição de manequins Jean Paul Gaultier, criadas originalmente para Musée des beaux-arts de Montréal - 2011

Neste desdobramento entre presença e ausência, animado e inanimado, vida e morte, é levantada uma questão antiga pertinente à relação do ator e a desconfiança sobre sua real necessidade. Para Craig o corpo do homem não é apropriado para servir de instrumento a uma arte. Fausticamente também prevê fundamentos da sociedade do controle ao categoricamente afirmar "mas enquanto o mundo durar, a natureza do homem lutará pela liberdade e revoltar-se-á por se fazer dela escravo [...]” (CRAIG, 1977, pág. 93) Ainda pondera que o teatro continuará a se desenvolver apesar dos atores, contudo, mais a frente ameniza seu discurso dizendo que o que afirmara era por amor ao teatro e que "[...] um extraordinário desenvolvimento vai erguer e reanimar o que está moribundo e que o ator contribuirá com todas suas forças [...] ”" (pág. 96).

Craig continua ainda a predizer não só um futuro cênico, como também os desejos fáusticos de controle da natureza, quando proclama que a nossa arte corresponde à fotografia, um recorte no tempo e no espaço, efetivado como verdade pelas ciências positivas. $\mathrm{O}$ ator assemelha-se a um aparelho fotográfico, que registra e reproduz a natureza. Desta forma então, afirma que o ator desaparecerá e no seu lugar um personagem inanimado surgirá: com o nome supermarionete "até que tenha conquistado um nome mais glorioso" (CRAIG, 1977, pág.108). Novamente levanta a ideia de um ídolo, de uma escultura, de objeto inanimado, que não rivaliza com a vida, e 
sim transcende ao corpo de carne e osso, como um espírito vivo. Reitera que na ciência ou em qualquer lugar que reina a vida há presenças invisíveis, de potências, de forças, de possibilidades. "[...] enquanto o fim desses homens irradia um clarão divino [...] os homens veem seu destino agravar-se [...] cedem a uma força intangível e inevitável" (pág. 272). Só a máscara pode efetivamente representar os estados da alma, essências da humanidade.

Similares às ideias de Craig sobre as dinâmicas reveladoras da máscara é o pensamento de Yeats. No seu teatro do anti-eu o personagem deve ser imerso num rompimento dos entraves do homem com o homem e a arte do mundo real só se aflora, só encontra o equilíbrio, o ritmo só pode ser atingido no limiar do transe. Neste axioma, a máscara é uma imagem fundamental, sobre-humana, na qual "[...] as estrofes, o ritual, a dança, a música[...], os gestos estilizados e o cenário não-realista devem unirse para manter a porta fechada contra um mundo intruso" (CARLSON, 1997, pág.298). Neste processo os espectadores entenderão o seu lugar no mundo, não por ação direta, mas por sugestão, por cores e gestos que permeiam o espaço não pelo intelecto, mas pela memória e pela imagem refletida.

Em Dors mom petit enfant, texto de Jon Fosse, a concepção da supermarionete evidencia-se através de um cenário minimalista com três pequenas criaturas (bonecos), com os rostos dos atores projetados sobre elas. Suspensos em uma plataforma falam calmamente, perguntam onde estão e discutem questões metafísicas, numa atmosfera que flutua entre a existência e seu oposto: o nada, o que não é a morte, mas o começo de tudo. Com um cenário branco como se fosse um limbo, as pequenas criaturas acentuam as questões do ator-animador, uma vez que a técnica de manipulação de bonecos requer uma troca energética da matéria com o corpo, que garante certa unidade ou sintonia entre animador e boneco, que porventura transfere ao objeto a emoção que corresponde à personagem. $\mathrm{O}$ trabalho com o boneco situa-se no paradoxo de mostrar o humano presente no objeto, o real e o irreal que a atuação do ator-animador torna verossímil.

Contudo, Marleau confere aos bonecos uma identidade de não-ser, sem manipulação humana proveniente do vídeo e segundo DUBOIS (2004) assume a posição de entremeio na multiplicação e maquinação do olhar no cogito ${ }^{37}$ de Descartes e

37 (René Descartes- 1596 a 1650) - Cogito ergo sum - penso logo existo, como se sabe, afirma a existência do sujeito na atividade do pensar: o ser aí é questão de conceito, concepção, conceitualização. Porque, apesar de todas as coisas poderem ser questionadas, se elas são do domínio da realidade ou de 
o percept $^{38}$ de Berkeley. Ou seja, o vídeo é uma tentativa técnica de dois grandes conceitos metafísicos: a conciliação do pensar e o ser visto, que forma a esquizofrênica tentativa de criação de identidades. $\mathrm{O}$ vídeo então revela-se enfim, de forma positiva na busca de si ou negativa na dissolução de toda a consistência do ser.
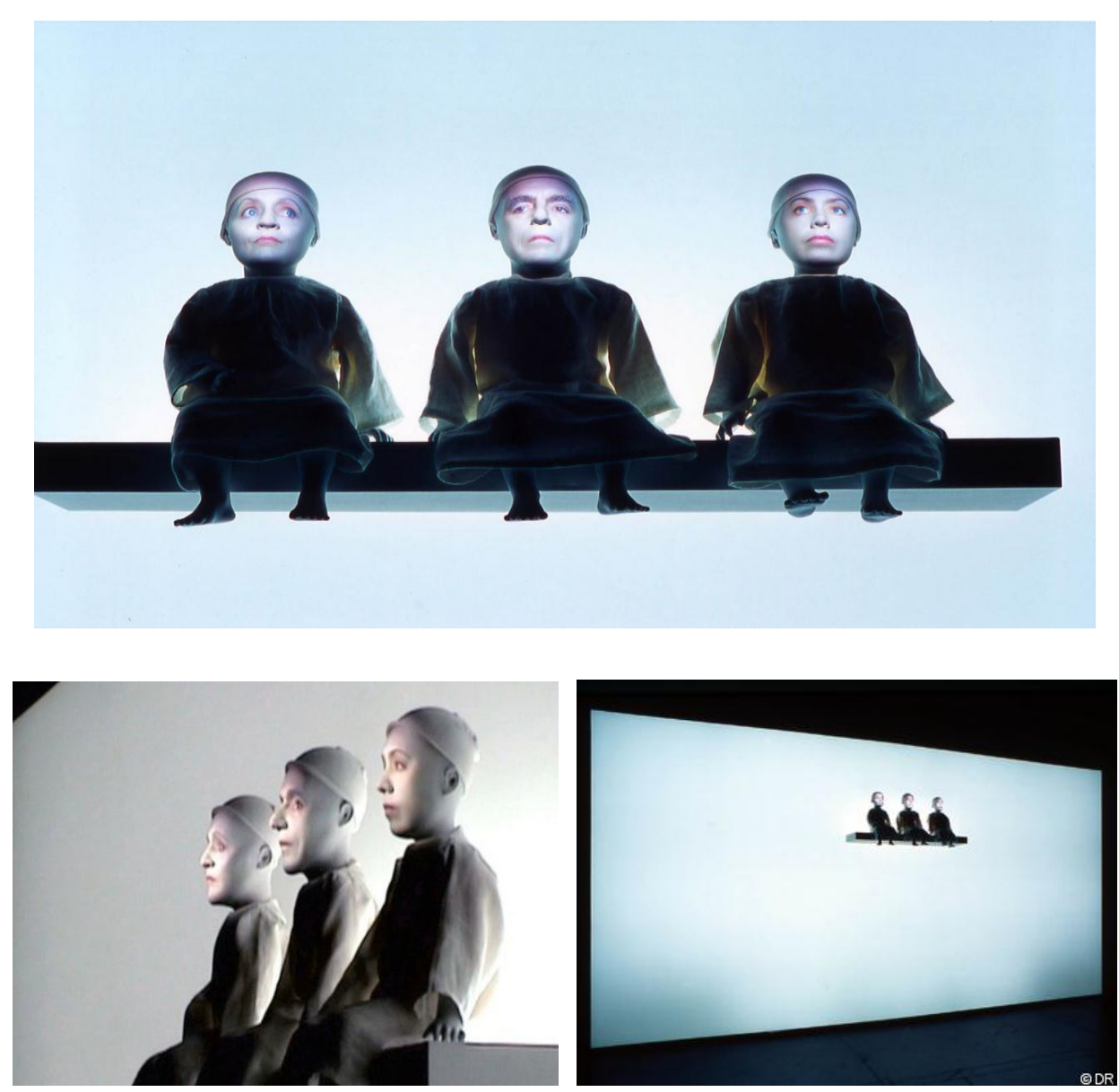

Figuras 43, 44 e 45 - Dors mom petit enfant - 2004

algum produto da imaginação (um sonho, a influência de um demônio, etc.), a própria ato de duvidar da própria existência serve como prova da realidade da existência de um próprio.

${ }^{38}$ Et percipit, Ser é ser percebido) conceito criado por Georges Berkely (1685-1753) que situa, por sua vez, o ser da perspectiva do percepto - de forma negativa, ou inversa, passiva: ser é ser percebido (e ao perceber). Sua primeira exposição da teoria, então revolucionária que os objetos só existem como percepção e não como matéria separada da percepção. Ele chamou a teoria Imaterialismo (concebida como era em oposição à predominante materialismo da época), embora mais tarde foi referido por outros como idealismo subjetivo. 
Para Kleist (1777-1811), em seu ensaio Sobre o Teatro de Marionetes, os bonecos encantam o espectador pela graça de seus movimentos, cuja simplicidade e leveza o tornam mágico. As imagens e figuras simbólicas que emanam ativam a imaginação. A leveza e graciosidade atingida pela marionete não pode ser alcançada pelo próprio homem e a marionete perfeita superaria o corpo humano. Segundo ele, o boneco, por não ter outra possibilidade senão as leis mecânicas, movimentando-se sempre pelo centro de gravidade, sendo mais gracioso, diferente do homem por movimentar-se fora do centro, por ser "afetado", desequilibrado. Para se atingir este estado da marionete seria preciso voltar a um estado de inocência, voltar a algo que ele já perdeu. Esta nostalgia que Kleist propõe parece um sincretismo com o cristianismo, onde o ser humano visa voltar à fonte, um caminho da existência humana, de uma alma sem o peso da matéria. Torna-se igual ao seu criador, torna-se um deus.

Entretanto, para os simbolistas, conscientes que a supressão do ator consumaria o fim do teatro, tentam prendê-lo dentro de uma dura rede estética, com o intuito de amenizar sua presença física e seus vícios de representação. Alfred Jarry (1873-1907) busca a solução na irrealização do gestual, dicção monocórdica, um retorno à máscara e caberia ao ator ser apenas um instrumento de evasão poética do autor. Nos devaneios simbolistas, ao proferir o texto, o ator materializa as palavras, encarnando-as e através de sua voz degrada a pureza do verbo.

Diga-se que é preciso que o ator tenha uma voz especial, que é a voz do papel, como se a cavidade da boca da máscara não pudesse emitir senão aquilo que a máscara diz, se os músculos dos lábios fossem maleáveis. E é até melhor que não sejam maleáveis, e que o registro em toda a peça seja monótono. (JARRY. 1896, pág. 06)

Jarry continua:

O ator "faz a cara", e deveria fazer todo o corpo, da personagem [...]. O ator deverá substituir a sua cabeça por uma máscara de cabeça, efígie da personagem. E se o caráter eterno da personagem está incluído na máscara, há um meio simples, paralelo ao do 
caleidoscópio e sobretudo ao do giroscópio, de pôr em luz, um a um ou vários em conjunto, os momentos acidentais. (pág.04).

Maeterlinck também em seu texto "Um teatro de androides" disserta sobre a questão da presença, sobre a necessidade física, real do ator. "Seria necessário talvez. afastar completamente o ser vivo da cena" "39. Sua ideia também era utilizar máscaras, substituir o ator por sombras, reflexos, projeções (fantasmáticas) "Toda obra-prima é um símbolo e o símbolo jamais suporta a presença ativa do homem" "40. Além disso, evoca as figuras de cera como modelo possível de um personagem inventado, que minimiza ao máximo a ação e coloca em cena, seres cuja única função seria a de articular de forma passiva o texto. A presença do ator não revelaria as camadas simbólicas, a força de toda uma obra, por outro lado, bonecos, marionetes, objetos, ou seres sem vida conteriam a energia extraordinária que todo o ser que possui a aparência de vida sem ter vida tem: a de encantar e propor ao espectador uma atmosfera mais orgânica e menos dinâmica como a cena realista.

Haveria um dia o uso da escultura, sobre a qual começamos a indagar estranhas questões? O ser humano seria substituído por uma sombra, um reflexo, uma projeção de formas simbólicas ou um ser que possuiria a aparência da vida sem ter vida? Não sei; mas a ausência do homem me parece indispensável. (MAETERLINCK. 1890. pág. 9192).

Nesta ânsia de controle total da cena as teorias simbolistas, de certa forma, corroboram com as leis da sociedade fáustica, devido ao tema "destino" ser para Maeterlinck um tema explícito e central. Ao contrário da causalidade trivial da experiência cotidiana, "o teatro deve exprimir a entrega dos homens ao destino de acordo com uma lei que permanece obscura" (LEHMAN. 2007, pág.96). As figuras parecem à mercê de uma magia misteriosa, com a alusão de uma comunicação de entrega, igual à do teatro Nô, que ocorre através do refúgio humano no mundo dos espíritos. Maeterlinck em sua época já prediz esta evasão do corpo, este corpo obsoleto,

\footnotetext{
${ }^{39}$ Maeterlinck - um teatro de androides, pág.91 - Pitágoras 500 - vol. 4 - Abr. 2013.

${ }^{40}$ Ibid.
} 
com sua intenção de suprimir a presença física do ator. Contudo Marleau, devido aos avanços da ciência e tecnologia, materializa em cena os parâmetros destes homens sem corpos bioinformaticamente alterados e concretiza não só os ideais simbolistas, mas as aspirações técnicas da sociedade fáustica de uma virtualidade humana iminente.

\subsection{2 - Presença na ausência}

Denis Marleau materializa as ideias que Maeterlinck, Jarry e Craig tanto preconizaram, a ideia da presença na ausência e da anulação da representação. Como também fomenta discussões sobre a vida sem corpo, do real e o virtual conceituadas pela sociedade fáustica. Na busca da imortalidade, as tecnologias da virtualidade costumam ser louvadas pela capacidade de ampliação, multiplicação e potencialização do ser humano. As possibilidades da bioinformática ampliam os espaços, ultrapassando os limites do corpo e anulando as distâncias geográficas. O pós-biológico medido pela conectividade, na reconfiguração da velha cultura biológica.

Todavia temos que considerar a enganosa oposição entre real e virtual. A explicação comumente usada no emprego da palavra virtual é dar significado a simples ausência de existência em contraponto com a realidade como efetivação material numa presença tangível. A palavra virtual vem do latim virtualis, derivado de virtus: força, potência. $\mathrm{O}$ virtual tende a atualizar-se, sem ter passado. "A árvore está virtualmente presente na semente [...] o virtual não se opõe ao real, mas ao atual" (LEVY. 1996, pág.15). Ambos, tanto virtualidade como atualidade, são maneiras diferentes de ser.

A atualização aparece como a resolução de um problema que não estava previamente pronunciado. A atualização é a criação, uma maneira de se atingir uma configuração dinâmica de forças e finalidades. A atualização é mais que dotar a realidade de uma possibilidade, ou uma produção de novas qualidades, um devir que alimenta o virtual. Um exemplo está na execução de um software, uma execução lógica - possível/real ao contrário da interface entre humanos e sistemas informáticos que tem a ver com a dialética do virtual e atual. Este software quando é atualizado por uma equipe de programadores encontrará, através de códigos, um caminho que acarretará em outros funcionamentos, desencadeará conflitos e novas configurações. Por outro lado, virtualização é um movimento inverso da atualização, através da vontade de potência 
confere-se a passagem do atual ao virtual. A virtualização não é uma desrealização, ou seja, a transformação de uma realidade possível, mas sim uma mutação de identidade. $O$ virtual é uma situação subjetiva, uma configuração dinâmica de tendências, de forças, de finalidades e coerções. A atualização é um acontecimento, efetua-se num ato que não estava pré-definido e que por sua vez, transforma uma configuração num significado. $O$ possível é uma forma à qual uma realização confere uma materialidade caracterizada como substância, oposta ao acontecimento (virtual, atual).

Marleau em suas pesquisas videográficas trabalha simultaneamente com real, o possível, o atual e o virtual, os quatro modos de ser descritos por Pierre Levy. O possível e o virtual têm traços em comum, anunciam antes um futuro do que oferecem uma presença. O real e o atual são promessas, estão presentes. Enquanto o real assemelha-se ao possível, o atual corresponde ao virtual.

Estes quatro modos operam conjuntamente em cada fenômeno concreto e segundo LEVY (1996) se a virtualização for obstruída, instaura-se a alienação, os fins não podem ser repostos, máquinas abertas, em devir, reduzem-se em mecanismos mortos. Se a atualização for cortada, as ideias, os problemas, deixam de ser inventivos. A inibição da potencialização direciona a ação ao sufocamento, ao esgotamento e por último, no caso da impossibilidade de realização, os processos perdem a concretude da ação.

Enfim o real, a substância, a materialidade, subsiste ou resiste. O possível contém as formas não manifestas, ainda letárgicas, ocultas no interior. A essência do virtual está na saída: ele existe. Por fim, na manifestação deste acontecimento, o atual acontece e sua operação encontra-se na ocorrência. A virtualização passa do aqui e agora, sai do tempo para enriquecer a eternidade, ela é fonte do tempo, das histórias, já que comanda as atualizações do ser e por sua condição criadora inventa questões, problemas, processos, atos e máquinas de devir. 


\begin{tabular}{|l|l|l|}
\hline & LATENTE & MANIFESTO \\
\hline Substância & Possível (insiste) & Real (subsiste) \\
\hline Acontecimento & Virtual (existe) & Atual (acontece) \\
\hline
\end{tabular}

Tabela 1 - os quatro modos de ser (Pierre Levy).

\begin{tabular}{|l|l|l|l|l|}
\hline TRANSFORMAÇÕES & DEFINIÇÃO & ORDEM & CAUSALIDADE & TEMPORALIDADE \\
\hline Realização & $\begin{array}{l}\text { Eleição, } \\
\text { queda de } \\
\text { potencial }\end{array}$ & Seleção & Material & Mecanismo \\
\hline Potencialização & $\begin{array}{l}\text { Produção de } \\
\text { recursos }\end{array}$ & $\begin{array}{l}\text { Seleção } \\
\text { problemas }\end{array}$ & Formal & Trabalho \\
\hline Atualização & $\begin{array}{l}\text { Invenção de } \\
\text { problemas de }\end{array}$ & Criaçãão & Final & Eternidade \\
\hline Virtualização & & & Processo \\
\hline
\end{tabular}

Tabela 2 - as quatro passagens de ser (Pierre Levy).

A ideia de imersão como desejo de imortalidade confere às tecnologias de virtualidade a potencialização e multiplicação das possibilidades humanas através da teleinformática, que permite ultrapassar os limites geográficos sem deslocamento do corpo, inaugurando fenômenos tipicamente contemporâneos como telepresença ou presença virtual. Sendo assim, oferecem novas experiências sem necessidade de organização do corpo, da linearidade do tempo e da materialidade do espaço. É a transposição do conceito homem-máquina prometeico para o homem-informação. De um lado o corpo mantém a priopercepção de sua existência carnal, por outro, as 
interfaces das quais o corpo é submetido aumentam seu poder perceptivo numa jornada em um mundo espectral.

\title{
3.6.3 - Fantasmagorias fáusticas
}

\author{
$O$ que é um fantasma? Um evento terrível \\ condenado a repetir-se continuamente. Um instante \\ de dor, talvez. Algo morte, que parece por um \\ instante ainda vivo. Um sentimento suspenso no \\ tempo. Como uma fotografia obscura, como um \\ inseto preso no âmbar.
}

A Espinha do Diabo - Guillermo Del Toro - 2011

Ao retirar a visão do corpo, sua ausência analogamente nos remete a um desejo puramente fáustico, de substituição da physis pela techne, exposto nas monstromáscaras de Denis Marleau, que nos remete a noção de presença dada pela pelo fantasma. Como a máscara, o fantasma está entre dois mundos, o sensível e o sobrenatural e reflete as possibilidades de congelamento do tempo. Como é também, a repetição da última imagem do morto e se parece com imagens em eterno loop de um etéreo gravador de vídeo.

O fantasma é uma imagem capturada pelo olhar de quem o fita aterrorizado, petrificado. Pode fazer surpreendentes revelações ou contar sua história de infortúnios e desvarios e parecer ao mesmo tempo matéria e não-matéria, pela costumeira representação do espectro como um corpo transparente. $\mathrm{O}$ fantasma necessita comunicar algo, que paralelamente denuncia o crime pelo qual foi vítima e profetiza os perigos que perscrutam os envolvidos na história. Ele aponta lugares, enigmas que engendram decifração. O fantasma é um duplo que captura nosso olhar, é sua imagem que vaticina passado e futuro dentro de um território da estranheza. 
Entre os séculos XVII e XVIII, a Europa teve um particular interesse no estudo das ilusões de óptica e do olhar humano, em especial com o jesuíta alemão Athanasius Kircher que desenvolveu diversos aparatos para produzir espetáculos luminosos que impressionavam seus espectadores. Depois das experiências de Kircher, o inventor francês Étienne Gaspard Robert (conhecido como Robertson) criou o fantascópio ou fantasmagoria (do grego phantasma, "fantasma" e agorenó, "eu falo” ou "eu chamo"). Toda técnica da fantasmagoria baseava-se no uso apropriado do fantascópio, que deveria ficar oculto do público por detrás da tela de projeção. Esse aparelho consistia, na verdade, em uma espécie de lanterna mágica equipada com um diafragma e um mecanismo que permitia seu deslocamento para frente ou para trás. "Desta forma uma imagem (um fantasma) parecia mover-se em direção à plateia, que se encontrava encerrada em uma sala escura, criando assim um clima de espanto sobrenatural". (FELINTO. 2008, pág. 71). O termo fantasmagoria passou a designação técnica de certo tipo de espetáculo óptico que criou uma nova espécie de imaginação. Uma forma que veio de encontro com as obras dos artistas românticos e simbolistas e tal imaginação, característica do sonho, pressupõe a abertura de um espaço interior.

Marleau leva à cena o que a sociedade reprime e projeta no cinema, "o devir do mundo dos sonhos, [..] o afloramento do fantasma, a emergência do imaginário[...]" (MACHADO, 1997, pág.15) como uma forma de exorcizar tais fantasmas. Segundo FELINTO (2008) o fantasma é uma imagem que não foi criada para ser propagada sobre nenhuma superfície. Apesar de ser reproduzido por meios audiovisuais em filmes, monitores de televisão, vídeos, sua imagem prescinde tais suportes, por ser uma mídia em si mesmo, que perturba o objeto e imagem, entre o animado e o inanimado.

Ele simboliza a entidade fáustica, virtualizadamente desejada em Les Avengleus obra escrita por Maeterlinck, e também chamada - Fantasmagories Technologiques $\mathrm{Na}$ história do dramaturgo simbolista, um grupo de homens e mulheres cegos adormecem durante um passeio na floresta. Ao acordarem, notam que seu guia não responde aos seus chamados. Ao esperarem o seu retorno, conversam para preencher o silêncio e afastar o medo gerado pelos ruídos que surgem do nada. Mas o guia não voltará: encontra-se morto, entre eles. 
A poética de Marleau declaradamente simbolista tem um caráter estático e tendência ao monólogo. No simbolismo abandona-se toda estrutura dramática, de ação e de imitação, além da ideia clássica do tempo linear e progressivo em favor de um tempo-imagem. Contra a coerção mimética naturalista, o simbolismo alude que a realidade sensível está no mundo das essências e a vocação do criador está em empenhar-se em decifrar os sinais deste mundo e se comunicar com ele. O teatro simbolista é mutação, o palco deveria ser um cerimonial que remete ao sagrado, ao mesmo tempo em que o dissimula no presente. ROUBINE (2000) afirma que por intermédio do simbolismo, a representação se desliga pela primeira vez da imposição mimética e da sujeição de um modelo baseado no real. No domínio teatral a difusão das ideias simbolistas estão ligadas à absoluta supremacia da palavra poética, único meio de entrar em contato com o mundo das essências. O que para alguns simbolistas a encarnação do texto poético feito para teatro resulta em uma saturação, uma materialização que degrada a poesia. Desta forma, os discursos direcionam-se em promover o valor supremo, o belo, a palavra do poeta, ao mesmo tempo que se quer desvalorizar, senão eliminar os elementos constitutivos da teatralidade. $O$ teatro simbolista renuncia à maioria das técnicas herdadas dos dois últimos séculos, qualquer interferência visual deve ser evitada para não prejudicar a comunhão poética. Busca-se o livre jogo da imaginação do espectador, que irá elaborar através de livres associações, por intermédio das palavras, a compreensão da obra.

Nas Fantasmagories Technologiques através de 12 máscaras videográficas, Marleau cria a ilusão de profundidade, onde seis homens interpretados pelo mesmo ator, Paul Savoie, e seis mulheres, interpretadas por Céline Bonier, proporcionam ao público um espetáculo de rara beleza visual, num misto de escultura, vídeo e teatro. "Imagens vivas" falam sobre a cena - com uma projeção complexa sem que nenhuma tecnologia seja visível e sem presença humana em tempo real.

Como espíritos saídos da escuridão, estas monstro-máscaras são o que DELLEUZE (1983) chama de imagem-afecção, o primeiro plano: o rosto. Ao se colocar em primeiro plano, na penumbra, os personagens, suas imagens videográficas alteram o espaço/tempo e eleva sua figura à potência de entidade. Não percebemos um espaço, quando ampliamos, quando isolamos e contemplamos este rosto da multidão. Podemos então fazer dois tipos de pergunta ao rosto - em que você pensa? Ou então: o que há 
com você. "Ora o rosto pensa em algo, se fixa em um objeto, e este é o sentido da admiração ou do espanto, que o wonder em inglês conservou" (pág. 105). Temos dois tipos de rosto: intensivo e reflexivo. Em suma, o rosto refletor não se contenta em pensar em algo. Assim como o rosto intensivo exprime uma potência pura, e define-se por uma série que nos faz passar de uma qualidade a outra, o rosto reflexivo exprime uma qualidade pura, isto é, um "algo" comum a vários objetos de natureza diferente. Desta forma, uma dimensão de outra ordem se abre a nós. É o que Epstein sugere quando afirma: o rosto de um covarde fugindo, assim que o vemos em primeiro plano, vemos a covardia em pessoa, vemos o "sentimento-coisa", a entidade. Se for verdade que a imagem de cinema é sempre desterritorializada, existe então uma desterritorialização muito especial própria da imagem-afecção.

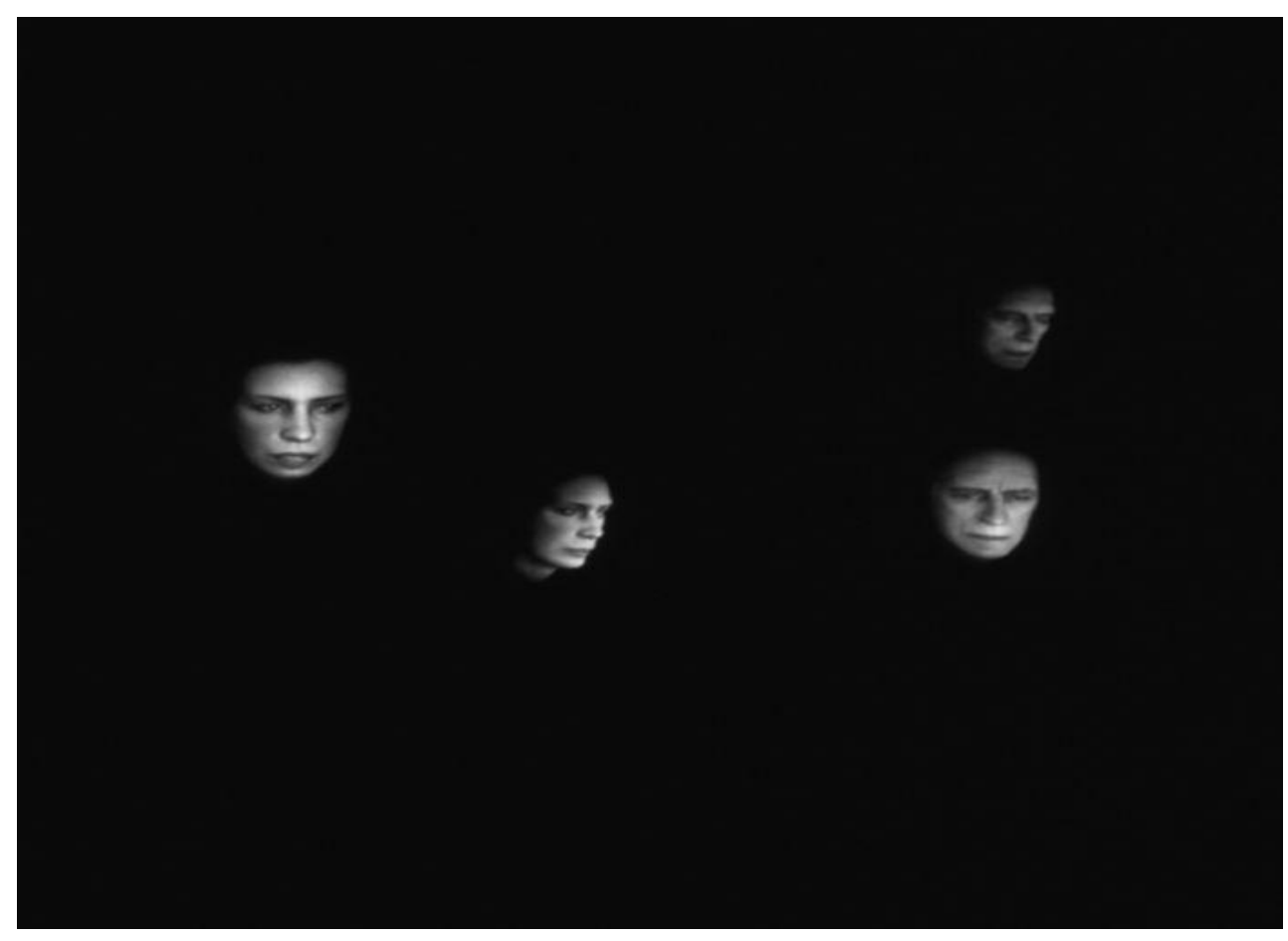




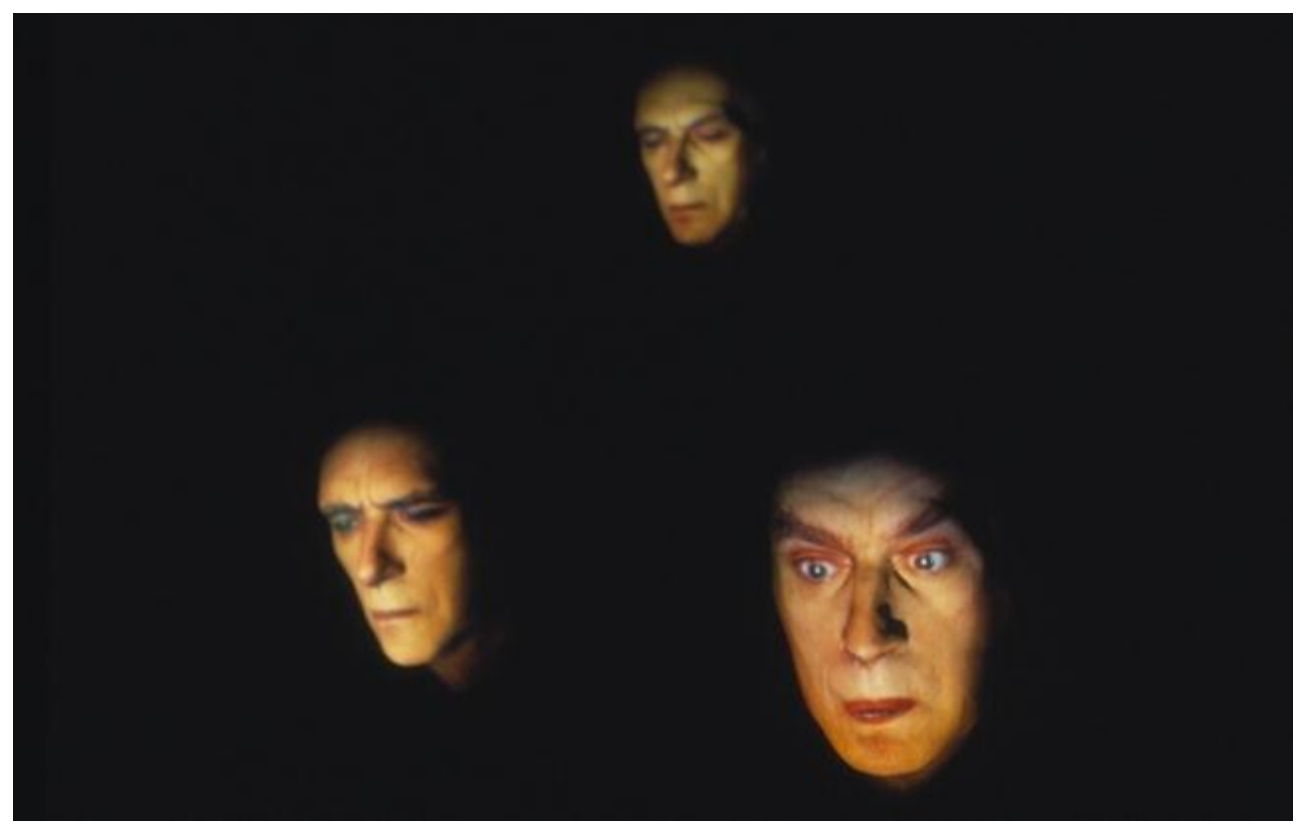

Figuras 46 e 47 - Les Aveugles - Fantasmagories Tecnhologiques - 2002.

O diretor canadense nos contempla sutilmente com uma visão do ideal fáustico de domínio total da natureza e não é de hoje que esta discussão existe. Durante milênios vigorou, na tradição ocidental, uma distinção radical entre physis e techne (em termos gregos) ou natura e ars (em termos latinos). Natural e artificial. Por um lado, o ser que é princípio do seu próprio movimento; por outro lado, as operações humanas para utilizar e ampliar o escopo do natural. Dois mundos nitidamente diferenciados. Hoje, porém, com fronteiras bem tênues. O corpo ausente prediz o corpo informação, que a partir da manipulação do DNA, coloca o gene como agente organizador e armazenador da vida fora de informações da forma (do organismo), que adquire status de ordem onde tudo é possível. Pois é a informação e não a matéria que define os rumos da vida nos ideais fáusticos onde "[...] o conteúdo daquilo que permutamos com o mundo exterior ao ajustar-nos a ele, [...] faz com que nosso ajustamento seja nele percebido" (WIENER, 1970, pág.18).

Este corpo informação simbolicamente representado na figura do monstro, como vimos no capítulo 1, serve como duplo catártico. Desta forma, Denis Marleau no espetáculo, Une fête pour Boris (2009), expõe o exagero, a deformação de caráter, onde a humilhação, a grosseria e o desejo permanente de suicídio permeiam a narrativa. Com 
texto do autor austríaco, Thomas Bernhard, Marleau coloca em cena 15 personagens com uma particularidade em comum, todos têm as pernas amputadas. Monstromáscaras que formam um coro de enfermos que questiona sua deficiência, dentro de um registro decadente e risível, onde expõem de forma agressiva seus sonhos e sua relação com a morte, bebendo, rindo jocosamente, protestando e cantando a plenos pulmões. A deficiência torna-se artifício teatral na contradição dos costumes, da máscara e do travestimento. É a humanidade amputada pela via do grotesco.

Na história, a Boa Dama perde suas pernas e seu marido em um acidente de carro, entretanto, apesar do infortúnio parece não ter perdido a nobreza e o ar assertivo. Ela é monstruosa, frágil e destrutiva. Cheia de desconfiança e ciúme, aterroriza todos ao seu redor, especialmente a empregada Johanna, que aparentemente aceita todas suas grosserias e Boris, seu novo marido, também sem as pernas, que escolheu em um asilo. Para o aniversário de Boris convida outros 13 aleijados para um jantar final hilário. Com uma atmosfera macabra apresenta uma realidade radicalmente reduzida: restrições espaciais, mutilações físicas e reduções linguísticas espelhadas pelo empobrecimento das relações humanas.

Com referências A Classe Morta, de Tadeusz Kantor, Une fête pour Boris, a morte é colocada em cena cerimonialmente, consiste no aniquilamento tragicômico do sentido, degrada os personagens e provoca uma comicidade de um paradoxal desejo de viver. $\mathrm{O}$ ator vulneravelmente humano torna-se parte da estrutura cênica. Para Kantor também os bonecos são como a essência primordial e esquecida do ser humano. Em uma espécie de troca, os corpos vivos em conexão com os objetos de cena transformam o palco numa paisagem da morte, em que a transição de pessoas para bonecos se torna imperceptível. Seu amor pelos bonecos se diferencia de Craig, pelo fato que para Kantor, o boneco não deveria rivalizar com o ator, mas criar outro modo de presença. 

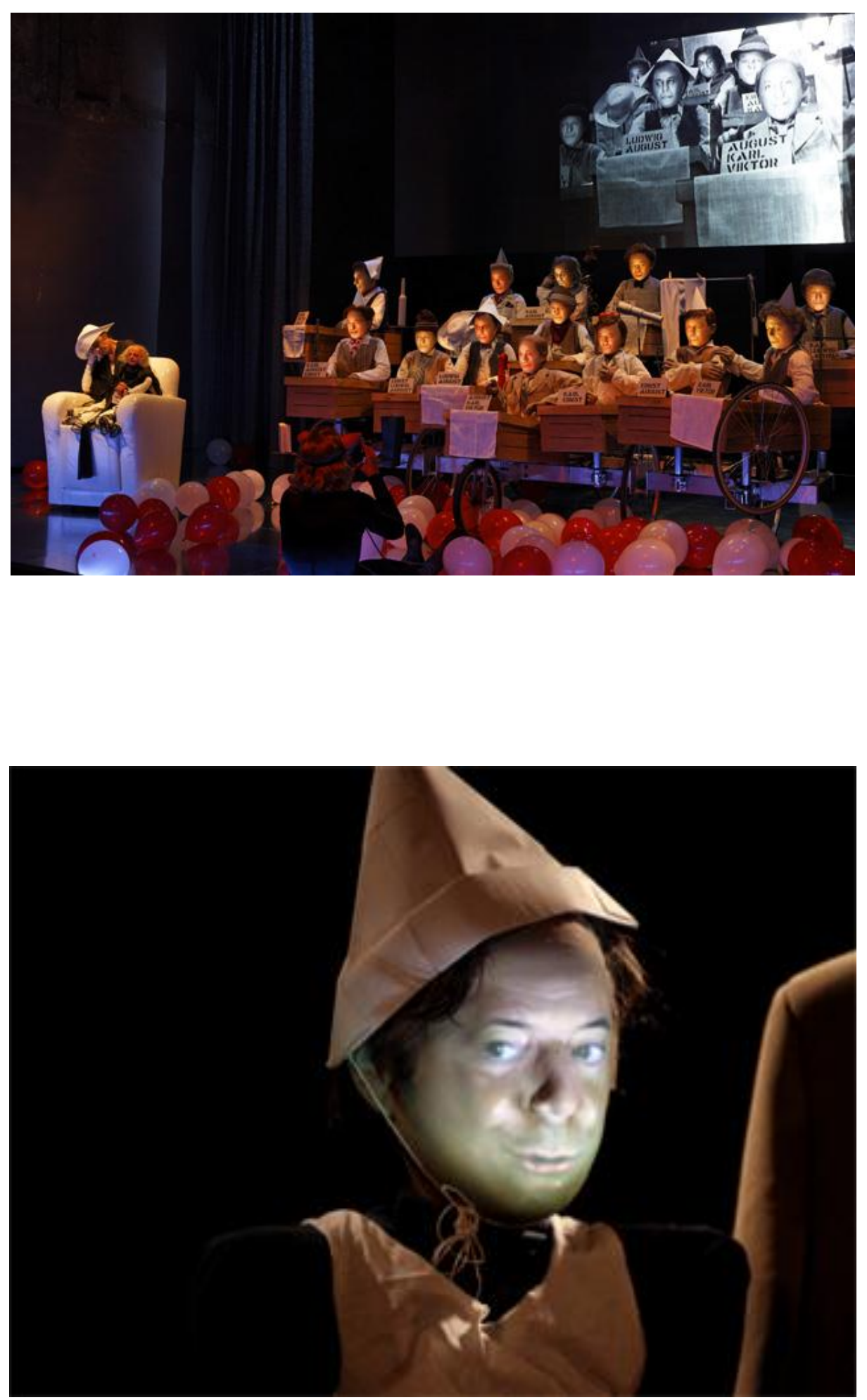


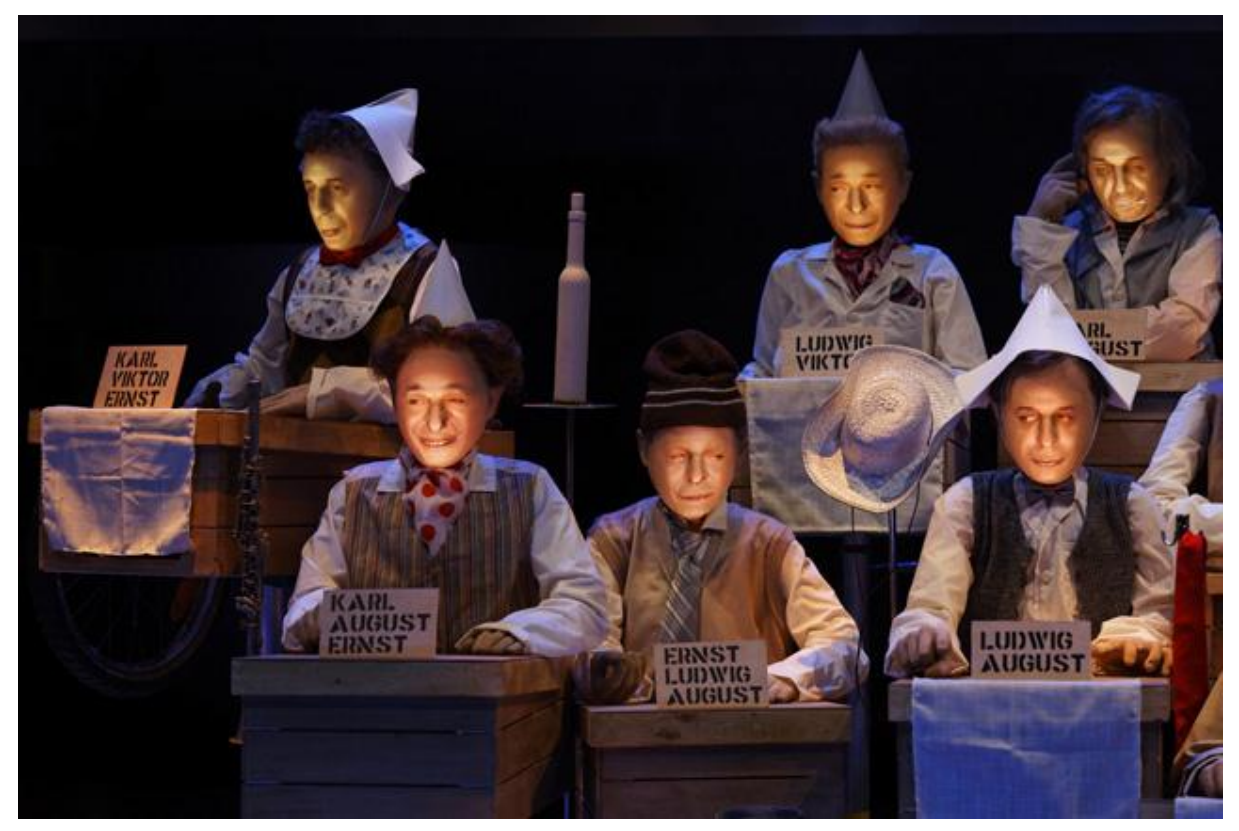

Figuras 48, 49 e 50 - Une Fête pour Boris - 2009.

Com Marleau as monstro-máscaras reduzem a imprevisibilidade. Se com Donasci o performativo, o improviso surge da união de vídeo e corpo; em Marleau seu rigor técnico, em sua estética visual apurada não há espaço para o acaso. Tudo é milimetricamente pensado, planejado, para que tudo aconteça sem erros, sem imprevistos. Para COELHO (2012) mais do que pensar em um ator virtual, poderíamos dizer que temos um ator representado através da sua projeção e da sua máscara. Pois o que temos em cena é uma imagem filmada (projeção), que em virtude da tela tridimensional (máscara) e da sonoridade (gravações sonoras), consegue simular uma presença real. Não há margem para o inesperado, para o improviso. O que há é uma tensão entre o orgânico e o inorgânico, que modifica ator e objeto.

Grande responsável por esta tensão, a imagem eletrônica é múltipla, variável, estável e complexa, transita numa infinidade de configurações, que aliada aos recursos, processos ou suportes informáticos eleva sua abrangência a enésima potência. Quando falamos sobre o vídeo nos colocamos fora de qualquer território institucionalizado, e como afirma MACHADO (1993) trata-se de um objeto híbrido, fundamentalmente impuro, de identidades múltiplas e que tende camaleonicamente se dissolver em outros objetos e incorporar seus modos de organização. 
Meio precário de registro naturalista, devido a sua limitada definição de imagem, o vídeo tende a dissolver as figuras num mar de reticulas, e o espectador, por sua vez, tem sua atenção solicitada pelo ambiente que o rodeia, distanciando ou o aproximando desta imagem. O vídeo de imagem ruidosa explicita a natureza fantasmática e sua característica videográfica privilegia a metamorfose, pelo fato de se poder intervir nela infinitamente, "subverter seus valores cromáticos, inverter a relação figura e fundo, tornar transparentes os seres representados, [...] a figura registrada resulta apenas num modelo gerador, a partir do qual se pode fantasiar largamente" (MACHADO. 1993, pág. 49). O vídeo é imagem-luz e ao contrário de outras imagens existe no tempo e não no espaço. A imagem eletrônica é síntese temporal de um conjunto de formas em mutação.

Em sua versão contemporânea de Agamennon, de Sêneca, que Marleau trás para cena, as monstro-máscaras assumem grandes proporções através de um cenário branco, com 15 enormes máscaras onde os rostos dos atores são projetados continuamente, com o mesmo rosto aparecendo em várias máscaras ao mesmo tempo. $\mathrm{O}$ assassinato do lendário rei de Micenas já inspirara Ésquilo a escrever a tragédia Agamêmnon. Meio século depois, Sêneca cria sua versão homônima na qual forças externas e imponderáveis regem o destino do homem e os infortúnios são todos decorrentes de conflitos internos.

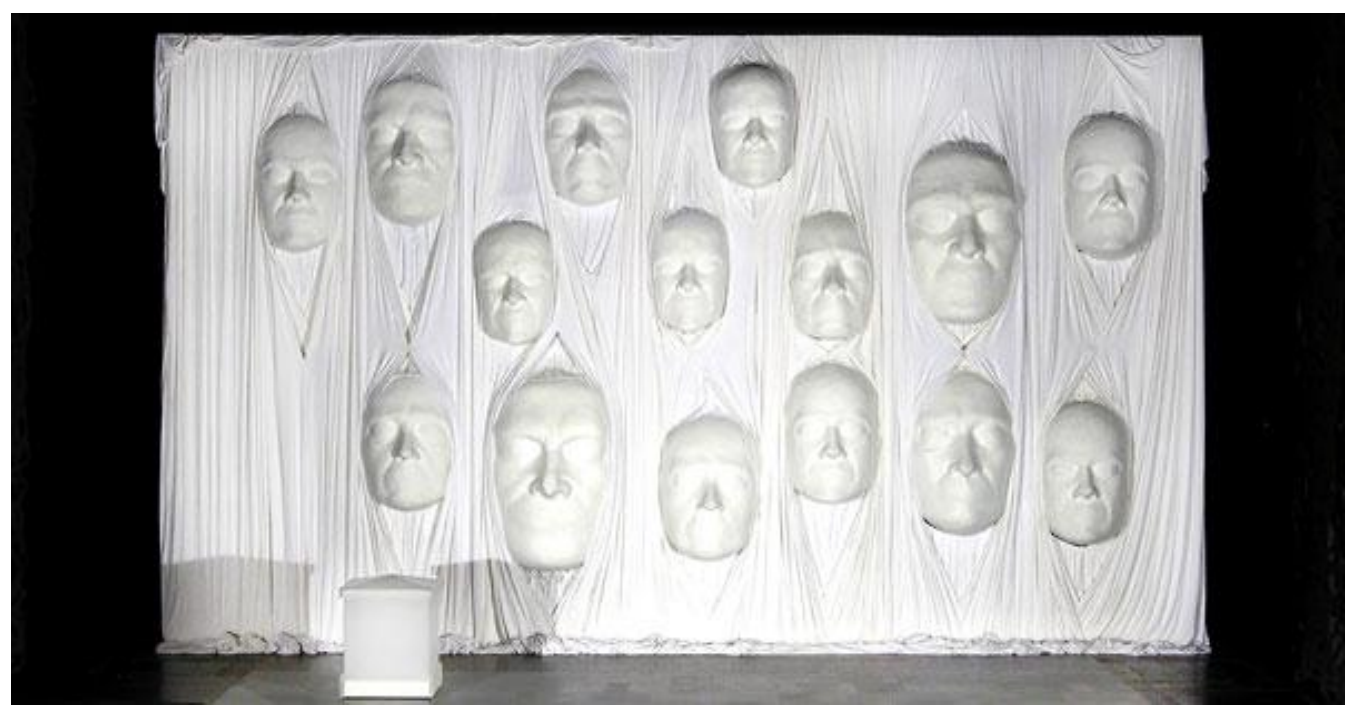




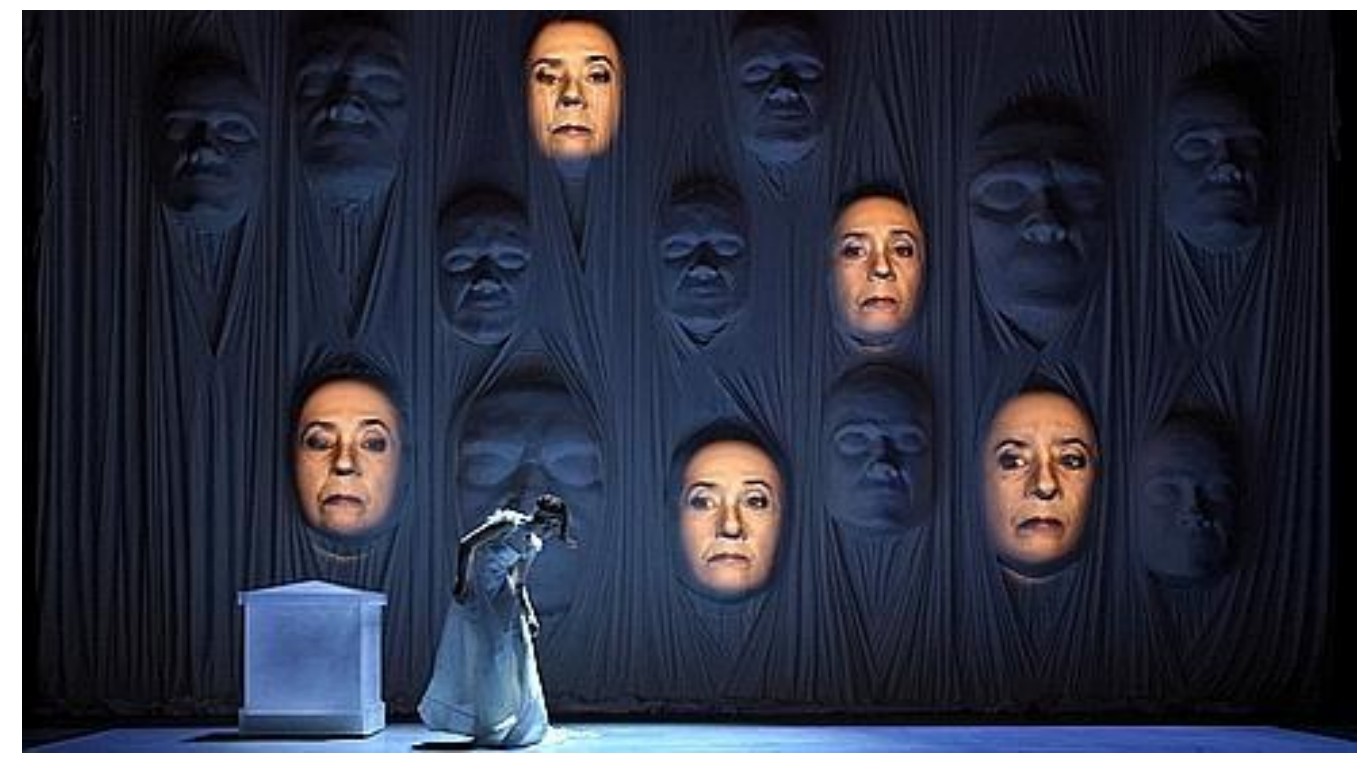

Figuras 51 e 52 - Agamennon - 2011

A solução videográfica gera um coro-monstro, que "mostra" o poder devastador dos vícios e das paixões por meio de situações que "demonstram" as consequências desastrosas do furor descomedido, da falta de controle dos sentimentos tanto para aquele que não os controla, quanto para os que o cercam. Na Grécia antiga o ator suspenso por uma máquina, o deus ex-machina, descia em carne e osso ao palco na figura de um deus, para rapidamente resolver os problemas mundanos. Esta técnica implica numa materialidade cênica que dava um final mágico ao espetáculo. Marleau coloca em cena o homem ex-machina, que antagonicamente virtualiza seu corpo para expor os problemas humanos e suas aspirações.

Marleau numa apurada construção técnica da cena carrega características “cíbridas”. Segundo ANDERS (1999) o cibridismo, união de ciber e híbrido é a capacidade que as novas tecnologias nos proporcionam para habitar dois mundos simultaneamente. Os sistemas cíbridos nascem das interconexões de espaços físicos e redes informacionais. "O espaço das semelhanças imediatas torna-se como um grande livro aberto; é carregado de grafismos; ao longo da página, veem-se figuras estranhas que se entrecruzam e por vezes se repetem" (FOUCAULT, 2000, pág. 37). Hora real, hora virtual, o comportamento cíbrido liberta da lei do lugar, desencadeia o fantasmático como já vimos, um ser preso entre dois mundos. 
Seja a morte, o vazio, a presença na ausência, o disforme, a técnica como controle total da natureza, ou a luta contra o acaso, as monstro-máscaras de Marleau abrem o debate sobre o fato de repensarmos as novas relações sociais atreladas à tecnologia defendida por ascetas fáusticos de superação das limitações humanas. A articulação corpo/sociedade/tecnologia é cada vez mais ponto crucial de discussão de muitos artistas sobre a bioinformatização do corpo e das potências mobilizadoras para tal realização desta imaterialidade. Sendo assim, o espectador é convidado a embarcar numa possibilidade futura, numa experiência sensorial, de conjecturas científicas, onde as imagens videográficas criam a ilusão, uma produção de presença e a digitalização do corpo. O transumano, o pós-humano é refletido dentro do possível, daquilo que um dia poderá existir, no sonho de transcendência com a máquina, da fusão da vida em uma tessitura suscetivelmente técnica de imortalidade.

\footnotetext{
Encarar a finitude não produz desespero, mas pode nos ajudar a melhorar na competência de viver. Pode causar algum desespero na medida em que seremos levados a fazer um caminho diferente daquele ao qual estamos acostumados, familiarizados e seguros, ou seja, o caminho da infinitude. (SEIBT, 2009. pág.373).
}

Como também, a tecnologia possibilita a Marleau concretizar pensamentos simbolistas pelo seu teatro estático, onde "os mortos que parecem nos falar com vozes solenes" (MAETERLINCK, 2013, pág.92) preconizam a figura da supermarionete de Craig e atualizam o discurso de mecanização da vida proveniente dos manifestos das vanguardas históricas. Pode-se ver uma correlação da cena marleauziana com o futurismo nas compenetrações e simultaneidades procedimentais de outras artes, como é o caso do cinema, através da noção de enquadramento, alterando a noção de tempo e espaço lineares e sucessivos. Da exaltação do maravilhoso e do devaneio dos surrealistas. Quando afirmam que o maravilhoso não é igual em todas as épocas e apenas parte dele chega até nós, pelo “[...] manequim moderno ou qualquer outro simbolo capaz de resolver a sensibilidade humana durante um tempo". 41 A ideia é colocar ao alcance de todos belas imagens como guia do espírito, que pouco a pouco, convencem-se da suprema realidade destas

\footnotetext{
${ }^{41}$ Breton, Manifestos do Surrealismo, 1924, pág. 38.
} 
imagens. No princípio, o homem sentiria-se limitado a elas, mas compreenderia que elas lisonjeiam sua razão e aumentam seu conhecimento da vida.

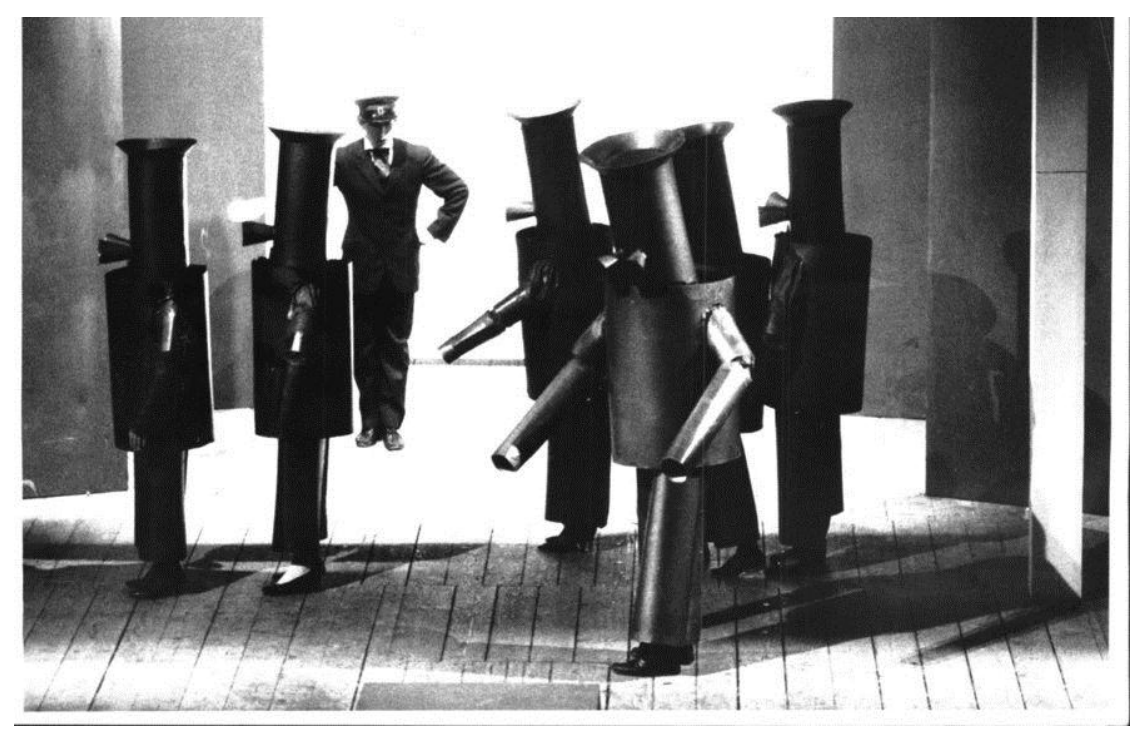

Figura 53 - Gran Serata Futurista 1909 - 1930 (1980) - Fabio Mauri.

Da estética da Bauhaus, Marleau busca em Oskar Schelmmer o conceito nietzschiano do dionisíaco versus o apolíneo, que considera o contraste entre os dois como forças da arte. Apolíneo é o lado positivo, o símbolo da luz, o mundo interior, a verdade dos estados de fantasia em contraponto da realidade cotidiana. Dionisíaco é o lado negativo, a afirmação triunfal da realidade nua e crua e suas imprevisibilidades. Não leva em conta a individualidade, dando a entender que o apolíneo é apenas uma ilusão. Tais formas então fundiriam a ordem com o caos na temática recorrente de capital, mecanização e arte.

As vanguardas artísticas denunciaram o tempo em que estavam inseridas, as desilusões com o poder político, o vazio humano e acima de tudo guardam no âmago de seus questionamentos a questão do homem e da máquina, um relacionamento de amor e ódio que culminará mais explicitamente, depois da segunda metade do século XX, nas correntes prometeicas e fáusticas que se apoiam na técnica como objeto de transformação social e domínio total da natureza. Entretanto, segundo BÜRGER (2008), o fracasso dos movimentos históricos apresenta três pontos cruciais. 1. A tentativa de superação do esteticismo da arte na práxis da vida no desenvolvimento da arte burguesa (crise desta sociedade na Primeira Guerra Mundial); 2. A impossibilidade de realizar tal 
projeto devido às condições sociais dadas e 3. A resistência da própria instituição. As vanguardas, por sua vez, não retrocederam às suas condições de partida, mas prepararam e apontaram o caminho pelo qual a sociedade se encaminhava.

Sendo assim, a era dos manifestos chega ao fim quando a filosofia se separou do "estilo", ou seja, uma vez que a definição filosófica da arte não implica em nenhum imperativo estilístico qualquer coisa passa a ser arte, o que BELTING (1995) chama de período pós-histórico. Por tal motivo, a arte tende a ser pluralista e não seguidora de narrativas mestres. As vanguardas artísticas tentaram extinguir seus antecessores, até que se evidenciou depois da segunda metade do século $\mathrm{XX}$, a não existência de condicionamentos filosóficos ou estilísticos. Artistas são agora especialistas, com técnicas aglutinantes numa Babel estética.

Então cabe à arte ser crítica, com seu movimento imanente à sociedade, um posicionamento de autocrítica, passando por múltiplas mediações que se fundamentam em posicionamentos sociais. De compreender objetivamente as épocas passadas para poder transmutá-la, de direcionar a experiência estética para a vida cotidiana, contestando o que a sociedade racionaliza como verdade de uma existência autoorganizada.

A fomentação de uma ideologia está vinculada a uma multiplicidade de significados em parte contraditórios entre si, uma vez que a objetivação intelectual muitas vezes não condiz com a realidade social. Em seu livro A Crítica da filosofia do direito de Hegel, Marx tece uma interessante análise sobre a religião, para explicar que através de uma falsa consciência denuncia-se o constructo ideacional, ao mesmo tempo em que não nega a verdade. A religião então seria uma ilusão onde, o homem projeta num outro lugar aquilo que gostaria que o mundo fosse. Ao acreditar cada vez mais em sua crença, objetiva as qualidades humanas, acentuando sua ilusão. No entanto, ao praticar tal ideologia expõe as misérias reais da vida, uma verdade que aponta a carência da humanidade na terra. Desta forma expõe, mesmo de forma alienada, um protesto contra aquilo (pecados) que não deveria existir. Pode-se fazer um paralelo da análise de Marx e o poder de alienação que uma imagem pode conferir à nossa vida, o poder de verdade absoluta da fotografia, do poder de sedução e imaginação do cinema, como também o vídeo impuro que por natureza reorganiza as formas de expressão. 
Comportamentos grotescos, figuras monstruosas e máscaras sociais como pudemos ver nos capítulos anteriores formam os elementos na vida e da arte utilizados como esquemas de controle, submissão e regulamentação de ideais. Através da técnica, que é inerente aos animais pela livre movimentação no espaço, de sua relação simbionte com a Natureza, o homem deseja uma relativa autonomia e independência que necessita para afirmar sua existência, para que ela ganhe significado. Esta mobilidade animal nada mais é do que sua tática de vida, um comportamento de luta. Portanto, a utilização de máquinas serve um determinado processo dentro de um domínio da natureza.

[...] luta primordial entre os animais primitivos, conduz aos atuais procedimentos dos inventores e engenheiros; que, da mais antiga das armas, a astúcia, vem entroncar na construção das máquinas com que impomos à Natureza e a submetemos aos nossos estratagemas. (SPENGLER, 1993, pág. 41).

As monstro-máscaras de Denis Marleau mostram a aposta entre Fausto e Mefisto como a eterna insatisfação do homem consigo mesmo, como a ação deve se pautar numa contínua estrada de transformação. Para Mefisto os finsjustificam os meios e em seu ponto de vista, Fausto é facilmente controlável, convencido a fazer o pacto, pois sabe que é da natureza humana gerar eternas coerções no meio em que vive. Mefisto e Fausto, espelhos, duplos em si mesmo, pactuam para transgredir, para adquirir conhecimento e para obter a imortalidade. "Fausto não pode absolutamente repelir Mefisto, mandá-lo embora, uma vez que o tem sempre junto a si em sua angústia em relação ao deter-se e em sua obsessão de consumir pela negação tudo o que existe" (JAEGER, 2007, pág.3). O espírito desse Fausto-Mefisto, espírito que sempre nega, é a imagem literária de Goethe para o pensamento processual que caracteriza a Modernidade, o qual nega todo o existente com vistas ao novo e o ainda-não existente. Vivemos uma tensa rede de pactos impostos política, social e economicamente, que proporciona a monstro-máscara viver o papel central de uma sociedade, onde o personagem se recusa a sair de cena, mesmo quando as luzes se apagam. 


\section{Recomeços finais}

E se um dia, ou uma noite, um demônio lhe aparecesse furtivamente em sua mais desolada solidão e dissesse: "Esta vida, como você a está vivendo e já viveu, você terá de viver mais uma vez e por incontáveis vezes; e nada haverá de novo nela, mas cada dor e cada prazer e cada suspiro e pensamento, e tudo o que é inefavelmente grande e pequeno em sua vida, terão de lhe suceder novamente, tudo na mesma sequência e ordem - e assim também essa aranha e esse luar entre as árvores, e também esse instante e eu mesmo.[...] A perene ampulheta do existir será sempre virada novamente - e você com ela, $[\ldots]$.

Nietzche, Gaia Ciência

Ao longo do tempo, monstros e máscaras foram utilizados como duplo do Homem, como objetos de expurgo e transformação. Monstros sempre foram artifícios usados como catarse ou contenção, habitando o limite fronteiriço entre o bem e o mal, como ponto central de ruptura da ordem econômica, social e política. Seu excesso de olhar, seu excesso de presença prende a atenção de quem o observa, exterioriza fantasias e é por isso que nasce: para ser morto e ressuscitado. Morto, porque é nele que exorcizamos nossos medos; e ressuscitado porque cada época necessita de uma nova forma deformante para seguir em frente, alguém para culpar por seus próprios infortúnios. Espelho da carne ou de sua falta, através dele transgride-se, transforma-se e transcodifica-se o invisível. A monstruosidade esconde-se na camada mais espessa, onde o caos reina absoluto e a partir dele o homem a todo instante se reconfigura, uma eterna volta à fonte. Um eterno retorno, uma eterna superação.

Por sua vez, o monstro também é uma máscara e pode tornar-se monstruosa conforme sua vontade. A máscara atravessa os tempos junto ao homem, escondendo-se para se revelar num paradoxo inerente a sua vontade de potência. Ao colocar a máscara 
torno-me outro, existo em um mundo fronteiriço entre o natural e o sobrenatural, sou espectador de dois mundos, como se zelasse para que o equilíbrio entre corpo e alma continuasse estável. Como palimpsesto corporal, atemporal, também dita regras, novas normas, propõe ou impõe passagens que suscitam novos deveres e novos direitos. Produto da ilusão, de atmosfera, de jogo onde não se admite o "não". Como símbolo através da forma, da multiplicidade e também da síntese amplia significados, encarando o mundo de frente. Por trás de uma máscara sempre há uma parcela do desconhecido para quem a utiliza e para quem a fita.

Por estarem inseridas na lei do eterno retorno monstro e máscaras denunciam ideologias, divulgam ideias, debatem regras, expõem normas, renovam posicionamentos sociais e se juntam para representar a atualidade humana. Máscaras (personas) e monstros (sombras) tornam-se as imagens poderosas incrustradas no insconciente coletivo. As personas se referem a como nos apresentamos ao mundo, como nos relacionamos com os outros, são nossos papéis sociais. Em várias fases de nossa vida, colocamos ou retiramos diversas máscaras, conforme nossas necessidades, desejos ou acontecimentos. Em cada cultura estabelece-se um padrão arquetípico suscetível de variação infinita projetado para o controle. Já o seu oposto, a sombra seria o que uma pessoa não desejaria ser, o lado negativo, a soma de tudo que é desagradável, que deve ser escondido. Inclui memórias, desejos, tendências e experiências contrárias aos padrões e ideais sociais. Quando a recusamos torna-se perigosa, pelo fato de projetarmos suas qualidades indesejáveis no outro. Parte integral de nossa natureza a sombra jamais pode ser eliminada, é fonte infinita de criatividade.

As monstro-máscaras videográficas de Otávio Donasci e Denis Marleau atualizam a linguagem da máscara teatral, expandindo as potencialidades expressivas e poéticas, ao mesmo tempo que exteriorizam o momento histórico pelo qual vivemos. Denunciam as sociedades prometeicas e fáusticas, seus anseios, fomentam a reflexão sobre os caminhos que a sociedade do controle intencionalmente nos induz. Desmascaram a eugenia, a desumanização, a virtualidade iminente do corpo, são máquinas semióticas de extraordinária capacidade de metamorfose que espelham a alteridade humana.

Além disso, ampliam as possibilidades pedagógicas no treinamento corporal do ator, uma vez que para sua utilização, é necessário o entendimento de uma técnica 
específica, como também, a aglutinação de outras técnicas que lhe dão base interpretativa. Sendo assim, abre-se um precedente para a inserção didática de novas tecnologias em sala de aula que servem como facilitador na composição de um corpo cênico, condizente com a geração Y (nascidos em 1980) e Z (nascidos a partir de 1990) e que se desenvolveram em meio as transformações tecnológicas.

Estas gerações cresceram em meio as atividades múltiplas e desde cedo já manipulam com certa destreza aparelhos eletrônicos como tablets, smartfones e outros gadgets informáticos. São pessoas digitais que "zapeiam" de um canal a outro, ao mesmo tempo que navegam na internet, que conversam ao celular e que possuem um conceito de um mundo desapegado das fronteiras geográficas. Para eles, a globalização não foi um valor adquirido no meio da vida, sendo assim, informação não lhes falta, estão um passo à frente em relação a outras gerações, e habilmente adaptam-se aos novos tempos engedrados pela hibridização.

Tal hibridização é fruto da presente aceleração técnica em nossa contemporaneidade, que sobrepõem a conexão do ritmo biológico ao tecnológico, criando uma situação ímpar em nossa sociedade. Doravante, o mundo preso à imprevisibilidade sofre radicais mudanças de pensamentos seja em termos da natureza ou culturais. NIEZSTCHE (1995) afirma que o homem não é um fim, e sim uma ponte, uma passagem para a transcendência. Um meio entre o animal e o "super-homem", uma máscara modelada conforme as ideologias.

Nesta corrente de pensamento, a biopolítica torna-se um dos fenômenos mais importantes dentro das sociedades industriais, com toda a gama de tecnologias de poder com foco nas populações. Todos Estados implementaram suas estratégias de planejamento, regulação e prevenção com o propósito de intervir nas condições de vida, impingindo modificações e imposições normativas. Nasce assim a população como problema político e uma série de dispositivos, como vimos anteriormente, disciplinares dos corpos individuais e coletivos implementadas através de instituições como as escolas, fábricas, hospitais e prisões. Apoiadas nas ciências sociais tinham como objetivo a docilização dos corpos e o aumento de sua força útil. Disciplina e biopolítica são um conjunto de técnicas voltadas para a dominação. Enquanto o primeiro atinge o homem-corpo, com a intenção de treiná-lo como organismo mecanizado, o segundo foca na proposta eugênica que regulamenta fatores vivos. As antigas instituições 
disciplinares e os espaços de enclausuramento abrem novas malhas de sujeição potencializadas pela tecnologia. Como afirma DELEUZE (1992), controle é o nome que Burroughs usa para designar este novo monstro e que Foucault enxerga como nosso futuro próximo.

O "Homem-Máquina de La Mettrie é uma redução materialista da alma e uma teoria geral do adestramento, no centro dos quais reina a noção de "docilidade" que une o corpo analisável ao corpo manipulável. É dócil o corpo que pode ser submetido, que pode ser utilizado, que pode ser transformado e aperfeiçoado. Os famosos autômatos, por seu lado, não eram apenas uma maneira de ilustrar o organismo; eram também bonecos políticos, modelos reduzidos de poder [...] (FOUCAULT, 2009, pág. 118).

Ao utilizarem as monstro-máscaras videográficas, Donasci e Marleau ampliam o espectro de debate sobre o pensamento contemporâneo ao exporem as facetas da hibridização do homem com a máquina. O primeiro prometeico e o segundo fáustico, denunciam os preceitos das sociedades do controle. Donasci com sua vontade de potência dionisicamente cria sua monstro-máscara como um ser anárquico, um terceiro ser, que amplifica, melhora as qualidades humanas, seus estados perceptivos, quer o improviso, o acaso. Marleau, gorgonicamente enfatiza a luta contra a imprevisibilidade, o rigor técnico como ferramenta artística e política, coloca em cena a virtualidade possível, investe no duplo de um novo ser e coloca em foco a morte como objeto de controle. Ambas monstro-máscaras videográficas preconizam um futuro. Seja como o eterno Prometeu ou como o insaciável Fausto um caminho já delineado começa a tomar forma: o transumano. 


\section{REFERÊNCIAS BIBLIOGRÁFICAS}

ABBAGAGNO, Nicola. Dicionário de Filosofia. São Paulo, Martins Fontes, 2001.

AgOSTINHO, Santo. A cidade de Deus. Petrópolis, editora Vozes, 2009.

AGRA, Lucio. História da arte do Século XX: ideias e movimentos. São Paulo. Editora Anhembi-Morumbi, 2004.

AMARAL, Ana Maria. Teatro de formas animadas: máscaras, bonecos, objetos. São Paulo. Edusp, 1991.

Editora Senac, 2002. . O ator e seus duplos: máscaras, bonecos, objetos. São Paulo.

ARHEIM, Rudolf. A arte do cinema. Portugal. Edições Lisboa 70, 1989.

Arte e percepção visual. Uma visão da psicologia criadora. Nova versão. São Paulo. Pioneira Thomson Learning, 2005.

ARISTÓTELES. Da história dos animais. Livro VII-X. Lisboa. Imprensa NacionalCasa da Moeda, 2008.

de México, 1946.

Obras completas, México. Editora Universidade Nacional Autónoma

ARTAUD, Antonin. O teatro e seu duplo. São Paulo. Editora Martins Fontes, 1999.

ASLAN, Odette. O ator no século $\boldsymbol{X X}$. São Paulo. Perspectiva, 2003.

Le masque, Du rite au théâtre. Paris, CNRS Éditions, 1999.

AUGRAS, Monique. $O$ duplo e a metamorfose : a identidade mítica em comunidades nagô. Petrópolis. Editora Vozes, 1983.

BACHELARD, Gaston. O direito de sonhar. Rio de Janeiro. Editora Bertrand Brasil, 1994.

BAIXAS, Joan. Escenas del imaginario. Internacional Festival of Visual Theatre and Puppets of Barcelona. XXV aniversario. Centro de Cultura Contenporània de Barcelona, 1998.

BAKHTIN, Mikhail. A cultura na Idade Média e no Renascimento. São Paulo: Editora Hucitec; Brasília. Editora da Universidade de Brasília, 1993.

BARTHES, Roland. A câmara clara : nota sobre a fotografia. Rio de Janeiro. Editora Nova Fronteira, 1984.

BAUDRILLARD, Jean. A troca simbólica e a morte. São Paulo. Edições Loyola, 1996. 
. Simulacros e simulação. Lisboa. Relógio d’Água, 1991.

BELLOUR, Raymond. Entre Imagens. Foto, Cinema, Vídeo, Campinas, Papirus, 1997.

BELTRAME, Valmor Níni e ANDRADE, Milton de (org.). Teatro de Máscaras. Florianópolis. UDESC, 2011.

BENJAMIN, Walter. A obra de arte na era de sua reprodutibilidade técnica. In: Obras escolhidas I. São Paulo. Brasiliense, 1987.

BENOIST, Luc. Signos, símbolos e mitos. Belo Horizonte. Interlivros, 1976.

BERGSON, Henri. O pensamento e o movente. Ensaios e conferências. São Paulo. Martins Fontes, 2006.

BERMAN, Marshall. Tudo que é sólido desmancha no ar. São Paulo. Editora Schwarz, 1986.

El Fausto de Goethe: la tragedia del desarrollo. Todo lo sólido se desvanece en el aire: La experiencia de la Modernidad. Madri: Siglo XXI, 1988. P.2880 .

BERTHOLD, Margot. História do Teatro Mundial. São Paulo. Editora Perspectiva, 2006.

BOECHAT, Walter. Quatro Grandes Mitos Humanos. Mitos e Arquétipos do Homem Contemporâneo. Petrópolis. Editora Vozes, 1995.

BRAUNSTEIN, Florence e PÉPIN, Jean-François. O lugar do corpo na cultura ocidental. Lisboa. Instituto Piaget, 1999.

BRETON, André. Manifestos do surrealismo. Lisboa. Salamandra, 1993.

BRETON, Philippe. À imagem do homem: do golem às criaturas virtuais. Lisboa. Instituto Piaget, 1995.

BURGER, Peter. Teoria da Vanguarda. São Paulo. Cosac Naify, 2008.

CALLOIS, Roger. Mito e homem. Lisboa. Edições 70, 1972.

Cotovia, 1990. Os Jogos e os Homens: a máscara e a vertigem. Lisboa. Edições

CAMPBELL, Joseph. O herói de mil faces. São Paulo. Editora Cultrix/Pensamento, 1995.

CARLSON, Marvin. Teorias do teatro. Estudo histórico-crítico, dos gregos à atualidade. São Paulo. Unesp, 1997.

UFMG, 2010.

Performance: uma introdução crítica. Belo Horizonte. Editora 
CAVALIERE, Arlete e VÁSSINA, Elena. Teatro russo - literatura e espetáculo. Ateliê Editorial, 2010.

CHEVAliER, J.; GHEERBRANT, A.Dicionário de Símbolos (mitos, sonhos, costumes, gestos, formas, figuras, cores, números), Rio de Janeiro. José Olympio, 1998.

COHEN, Jeffrey Jerome. Pedagogia dos Monstros - os prazeres e os perigos da confissão de fronteiras. Belo Horizonte. Autêntica, 2000.

COHEN, Renato. Performance como linguagem. São Paulo. Perspectiva, 2007.

CONGER, John P.. Jung e Reich. O corpo como sombra. São Paulo. Summus, 1993.

CORBIN, Alain; COURTINE, Jean-Jacques e VIGORELLO, Georges. História do Corpo: As mutações do olhar: $\boldsymbol{O}$ século $X X$. Volume dirigido por COURTINE, JeanJacques. Petrópolis. Editora Vozes, 2008.

COURTINE, Jean Jacques. Os Stakhanovistas do narcicismo. Body-building $\boldsymbol{e}$ puritanismo ostentatório na cultura americana do corpo. In SANT'ANNA, Denise Bernuzzi. Políticas do Corpo. Elementos para uma história das práticas corporais. São Paulo. Estação Liberdade, 1995.

COUTO, Edvaldo Souza. A satelização do corpo: uma estratégia do pós-humana de sobrevivência SILVA, Dinorá Fraga da e FRAGOSO, Sueli (orgs.). Comunicação e cibercultura. São Leopoldo. Editora Unisinos, 2001.

CRAIG, Edward Gordon. Da arte do teatro. Barcelos. Companhia Editora do Minho, 1977.

DANTO, Arthur. Após o fim da arte. A arte contemporânea e os limites da história. São Paulo. Odysseus: Edusp, 2006.

DELEUZE, Gilles. Diferença e Repetição. Rio de Janeiro. Graal, 1998.

Post-scriptum sobre as sociedades de controle. Conversações: 1972-1990. Rio de Janeiro: Ed. 34, 1992, p. 219-226.

Sobre o teatro: um manifesto de menos; O esgotado. Rio de Janeiro. Editora Zahar, 2010.

DEL PRIORE, Mary. Esquecidos por Deus. Monstros no mundo europeu e iberoamericano: uma história dos monstros do Velho e do Novo Mundo (séculos XVIXVIII). São Paulo. Companhia das Letras, 2000.

DELUMEAU, Jean. História do Medo no Ocidente: 1300-1800, uma cidade sitiada. São Paulo. Companhia das Letras, 1996.

DOMINGUES, Diana (org.). Arte e vida no século XXI. Tecnologia, ciência e criatividade. São Paulo. Editora UNESP, 2003.

São Paulo. Editora UNESP, 1997.

Arte no Século XXI: A humanização das tecnologias. 
DORT, Bernard. O teatro e sua realidade. São Paulo. Editora Perspectiva, 1977.

DUBOIS, Philippe. Cinema, vídeo, Godard. São Paulo. Cosac Naify, 2004.

ECO, Umberto. A história da feiúra. Rio de Janeiro/São Paulo. Editora Record, 2007.

ELIADE, Mírcea. Mito do eterno retorno. Arquétipos e repetição. Lisboa. Edições 70, 1981.

Mito e realidade. São Paulo. Editora Perspectiva, 2000.

FABRIS, Annateresa. Futurismo uma poética da modernidade. São Paulo. Editora Perspectiva/Edusp, 1987.

FELINTO, Erick. A imagem espectral: comunicação, cinema e fantasmagoria tecnológica. São Paulo. Ateliê Editorial, 2008.

FO, Dario. Manual mínimo do ator. São Paulo. Editora Senac, 1999.

FOUCAULT, Michel. Os Anormais. São Paulo. Martins Fontes, 2001.

. As palavras e as coisas. Uma arqueologia das ciências humanas.

São Paulo. Martins Fontes, 2000.

2009.

Vigiar e Punir: o nascimento da prisão. Petrópolis. Editora Vozes,

FLUSSER, Vilém. A história do diabo. São Paulo. Annablume, 2008.

FRANCO JÚNIOR, Hilário. A Idade Média: o nascimento do ocidente. São Paulo. Brasiliense, 2001.

FRAZER, James George. O ramo de ouro. Rio de Janeiro. Editora Zahar, 1982.

FREUD, Sigmund. $\boldsymbol{O}$ estranho, 1919. História de uma neurose infantil. Rio de Janeiro: Imago, 1996. p. 233-270. (Edição standard brasileira das obras psicológicas completas de Sigmund Freud, 17).

GARCIA, Silvana. As trombetas de Jericó: teatros de vanguarda histórica. São Paulo. Editora Hucitec, 1997.

GIL, José. Metamorfoses do Corpo. Lisboa: Editora d’Água, 1997. . Monstros. Lisboa. Relógio D’Água Editores, 2006.

GHIRALDELLI JR., Paulo. O corpo. Filosofia e educação. São Paulo. Editora Ática, 2007.

GLUSBERG, Jorge. A arte da performance. São Paulo. Editora Perspectiva, 2009.

GOLDENBERG, Roselee. A arte da performance. Do futurismo ao presente. São Paulo. Martins Fontes, 2006.

GUMBRECHT, Hans Ulrich. Produção de presença. O que o sentido não consegue transmitir. Rio de Janeiro: Contraponto. Editora PUC-Rio, 2010. 
HARAWAY, Donna e KUNZRU, Hari. Antropologia do ciborgue: as vertigens do pós-humano. Belo Horizonte. Autêntica Editora, 2009.

ICLE, Gilberto. O ator como xamã. São Paulo. Editora Perspectiva, 2006.

JEHA, Julio (org.). Monstros e monstruosidades na literatura. Belo Horizonte. Editora UFMG, 2007.

Horizonte. Editora UFMG, 2009.

JUNG, Carl Gustav. Os Arquétipos e o inconsciente coletivo. Petropólis. Editora Vozes, 2002.

KANTOR, Tadeusz. O teatro da Morte. BABLET, Denis (org.). São Paulo. Editora Perspectiva, Edições SESC SP, 2008.

KAPPLER, Claude. Monstros, demônios e encantamentos no fim da Idade Média. São Paulo. Martins Fontes, 1994.

KAYSER, Wolfang. O Grotesco. Configuração na pintura e na literatura. São Paulo. Editora Perspectiva, 1986.

KLEIST, Heinrich von. Sobre o teatro de marionetes. Rio de Janeiro. Sette letras, 1997.

LASCAULT, Gilbert. Le monstre dans l'art occidental: um problème esthétique. Paris. Klincksieck, 1973.

LEÃO, Lúcia (org.). O chip e o caleidoscópio: reflexões sobre as novas mídias. São Paulo. Editora Senac, 2005.

LE BON, Gustave. Psicologia das multidões. Porto. Edições Roger Delraux, 1980.

LE BRETON, David. Adeus ao corpo: antropologia e sociedade. Campinas. Papirus, 2003. A sociologia do corpo. Petrópolis. Editora Vozes, 2010.

LECOQ, Jacques. O corpo poético : uma pedagogia da criação teatral. São Paulo. Editora Senac, 2010.

LECOURT, Dominique. Humano pós-humano - a técnica e a vida. São Paulo. Edições Loyola, 2005.

LEHMANN, Hans-Thies. O Teatro pós-moderno. São Paulo. Cosac Naify, 2006.

LÉVY, Pierre. O que é virtual? São Paulo. Editora 34, 1996.

LIMA, Márcio José Silveira. As máscaras de Dionísio: filosofia e tragédia em Nietzsche. São Paulo. Discurso Editoral Ijuí. UNIJUÍ, 2006. 
LYOTARD, Jean-François. $O$ inumano. Considerações sobre o tempo. Lisboa. Editorial Estampa, 1989.

LYON, Henry R. Dicionário da Idade Média. Rio de Janeiro. Jorge Zahar, 1997.

MACHADO, Arlindo. Máquina e Imaginário. O desafio das poéticas tecnológicas.

São Paulo: Edusp, 1993.

Rios Ambiciosos, 2001.

O quarto iconoclasto e outros ensaios hereges. Rio de Janeiro:

Pré-cinemas \& pós-cinemas. Campinas. Editora Papirus, 2005.

A arte do vídeo. São Paulo. Editora Brasiliense, 1997.

MAERTENS, Thierry. Le masque et le miroir: essai d'anthropologie des revêtements faciaux. Paris, Aubier Montaigne, 1978.

MANNONI, Laurent. A grande arte da luz e da sombra: arqueologia do cinema. São Paulo. Editora Senac; Editora UNESP, 2003.

MARTINS, Hermínio. Hegel, Texas e outros ensaios de teoria social. Lisboa. Edições Século XXI, 1996.

e GARCIA, José Luis, com colaboração de JERÓNIMO, Helena Mateus. Dilemas da Civilização Tecnológica. Lisboa. Imprensa de Ciências Sociais, 2003.

MCLUHAN, Marshall. Os meios de comunicação como extensões do homem. São Paulo. Editora Cultrix, 1979.

MEIERHOLD, Vsevolod. Textos Téoricos. Madri. Alberto Corazón, 1970.

MELLO, Christine. Extremidades do vídeo. São Paulo. Editora Senac, 2008.

MERLEAU-PONTY, Maurice. Signos. Barcelona. Editorial Seix-Barral, 1964.

Fontes, 1999.

Fenomenologia da Percepção. São Paulo. Martins

MINKSY, Marvin. La sociedad de la mente. La inteligencia humana a la luz de la inteligencia artificial. Buenos Aires. Ediciones Galápagos, 1986.

MONTEIRO, Marko Synésio Alves Monteiro. Os dilemas do humano. Reiventando o corpo numa era (bio)tecnológica. São Paulo. Annablume Editora, 2012.

MORAES, Eliane Robert. Anatomia do Monstro. Corpo território da cultura. BUENO, Maria Lúcia; CASTRO, Ana Lúcia (org.). São Paulo. Annablume Editora, 2005. 
NAZÁRIO, Luiz. Da natureza dos monstros. São Paulo. Arte \& Ciência, 1998.

NARUYAMA, Akimitsu. Freaks - Aberrações Humanas. Portugal. Livros e Livros, 2000 .

NIETZSCHE, Friedrich. A Origem da Tragédia. São Paulo, Editora Cupolo, 2006. Vontade de Potência. Petrópolis. Editora Vozes, 2011.

Gaia Ciência. Curitiba. Hemus Editora, 2002.

Assim falava Zaratustra. São Paulo. Bertrand Brasil, 1995.

NOGUEIRA, Carlos Roberto Figueiredo. O Diabo no imaginário cristão. São Paulo. EDUSC, 2000.

NOVAES, Adauto. O homem-máquina: a ciência manipula o corpo. Adauto Novaes (org.). São Paulo: Companhia das Letras, 2003.

PAVIS, Patrice. Dicionário de Teatro. São Paulo. Perspectiva, 2007.

PEREIRA JR, Edvaldo Costa; SILVEIRA, Fabiano Augusto Martins e ROBERTO, Giordano Bruno Soares. História do Direito. Novos caminhos e novas versões. Capítulo 8. Roteiro para leitura do Malleus Maleficarum. Belo Horizonte. Mandamentos Editora, 2007.

PICON-VALLIN, Béatrice. A cena em ensaios. São Paulo, Editora Perspectiva, 2008.

A arte do teatro: entre a tradição e a vanguarda.

Meierhold e a cena contemporânea. Rio de Janeiro. Letra e Imagem, 2006.

RANK, Otto. O Duplo. Rio de Janeiro. Coeditora Basílica, 1939.

RAMOS, Luis Fernando. Por uma teoria contemporânea do espetáculo: mimeses e desempenho espetacular. Texto e imagem: estudos de teatro. WERNECK, Maria Helena e BRILHANTE, Maria João (org.). Rio de Janeiro. 7letras, 2009.

RIPELLINO, Angelo Maria. Maiakóvski e o teatro de vanguarda. São Paulo, 1986.

ROSNAY, Joel de. Homem Simbiótico. Perspectivas para o terceiro milênio. Petrópolis. Editora Vozes, 1997.

ROSSET, Clement. O Real e seu duplo. Porto Alegre. LPM, 1988.

ROUBINE, Jean-Jacques. Introdução às grandes teorias do teatro. Rio de Janeiro. Editora Zahar, 2003.

RYNGAERT, Jean-Pierre. Para ler o teatro contemporâneo. São Paulo. Martins Fontes, 1998.

SANTAELLA, Lucia; ARANTES, Priscila. Estéticas tecnológicas. Novos modos de sentir. São Paulo. Editora PUC, 2008. 
Cultura e artes do pós-humano: da cultura das mídias à cibercultura. São Paulo. Paulus, 2003.

2008. Corpo e comunicação: sintoma da cultura. São Paulo. Paulus,

2007. Linguagens líquidas na era da mobilidade. São Paulo. Paulus,

SIBILIA, Paula. O homem pós-orgânico. Corpo, subjetividade e tecnologias digitais. Rio de Janeiro. Relume Dumará, 2003.

SIMODON, Gilbert. Du mode d'existence des objets techniques. Paris. Aubier, 2008.

SODRÉ, Muniz. A comunicação do grotesco: introdução da cultura de massa brasileira. Rio de Janeiro. Mauad, 2004.

SPENGLER, Oswald. O homem e a técnica. Lisboa. Guimarães Editores, 1993.

STOLS, Eddy; THOMAS, Werner e VERBERCKMOES, Johan (eds.). Naturalia, Mirabilia \& Monstrosa em los Impérios Ibéricos (Siglos XV-XIX). Bélgica. Leuven University Press, 2006.

STRAUSS, Anselm. Espelhos e máscaras: a busca da identidade. São Paulo. EDUSP, 1999.

SZONDI, Peter. Teoria do drama moderno: 1880-1950. São Paulo. Cosac Naify, 2001.

TUCHERMAN, Ieda. Breve história do corpo e de seus monstros. Lisboa. Nova Veja, 2004.

VARELA, Jorge e MARTORELL, Amparo Ruiz. El actor oculto: máscaras, sombras e títeres. Castellón: Servicio de Publicaciones/Diputación Provincial de Castellón, 1986.

VENTURELLI, Suzete. Homem artista, deus criador ou feiticeiro ciborgue. In DOMINGUES, Diana (org,). Arte e vida no século XXI. Tecnologia, ciência e criatividade. São Paulo. Editora UNESP, 2003

VERNANT, Jean-Pierre. Figuras, ídolos, máscaras. Lisboa. Teorema, 1991.

e NAQUET, Pierre Vidal. Mito e tragédia na Grécia antiga.

São Paulo. Editora Perspectiva, 2005.

VILLAÇA, Nízia. A Edição do corpo. Tecnociência, artes e moda. Baureri, São Paulo. Estação da Letras Editora, 2007.

e GÓES, Fred. Em Nome do Corpo. Rio de Janeiro. Rocco, 1998. 
WIENER, Norbert. Cibernética e sociedade: o uso humano dos seres humanos. São Paulo. Editora Cultrix, 1970.

ZAMORA, Guerrero Juan. História del teatro contemporâneo. Barcelona. Juan Flors Editor, 1961.

\section{$\underline{\text { Trabalhos Acadêmicos }}$}

COELHO, Maíra Castilhos. A presença de corpos ausentes. A fantasmagoria de Denis Marleau em os Cegos de Maurice Maeterlinck. Dissertação de Mestrado em Artes Cênicas. Instituto de Artes, UFRS. Porto Alegre, 2012.

COSTA, Felisberto Sabino. A Outra Face: A Máscara e a (Trans)formação do Ator. Tese pós-doutorado, Escola de Comunicação e Artes, USP. São Paulo, 2006.

FELÍCIO, Vera Lúcia Gonçalves. Máscara: processo de metamorfose, enigma do nãoimaginário. Tese de Livre-Docência, USP. São Paulo, 1990.

LOPES, Elizabeth Pereira. A máscara e a formação do ator. Tese de Doutorado em Artes. Instituto de Artes da UNICAMP. Campinas, 1991.

NASCIMENTO, Otávio do. Videocriaturas: análise de performances entre 1980 e 2001. Dissertação de Mestrado em Audiovisual. Escola de Comunicação e Artes, USP, 2002.

VIVIANI, Ana Elisa Antunes. $O$ salto de volta à multidimensionalidade: perspectivas de compreensão do corpo na cibersociedade. Dissertação de Mestrado - Escola de Comunicação e Artes. USP, 2007.

\section{$\underline{\text { Artigos }}$}

ACHCAR, Ana. Caderno de Textos sobre a máscara. (Investigação e Documentação Teatral). Depto. de Extensão, Unirio - Rio de Janeiro, 2001.

AGRA, Lúcio. Autor/autores - performance no coletivo ou de como a reencenação da performance é um fator estratégico para sua pedagogia. Revista Sala Preta. V.8, n.1, 2008.

CABRAL, Maria de Jesus. Stéphane Mallarmé, um moderno clássico - notas sobre “Erechtheus. Tragédie par Swinburne (1876). Revista Máthesis no 14 - págs. 169-197. Jandaia Do Sul. Editora Fafijan, 2005.

FABBRINI, Ricardo Nascimento. Fim das vanguardas: estetização da vida e generalização do estético. Poliética. São Paulo, v. 1, n. 1, pág. 167-183, 2013. 
FERAL, Josete. Por uma poética da performatividade. O teatro performativo. Revista Sala Preta, v.08, 2008.

FRANCO FERRAZ, Maria Cristina. Sociedade Tecnológica de Prometeu a Fausto. Contracampo, Niterói: IACS/UFF, v.4, p. 117-124, jan.2000.

FOUQUET, Ludovic. Voyages en absence: quatre propositions de Denis Marleau. Jeu: revue de théâtre, nº 111, (2), pág. 154-160, 2004.

GRACIA, Silvio de. A Dimensão eletrônica. Da obsolescência do corpo às estratégias da tecnoperformance. Performance presente futuro. LABRA, Daniela (org.). Rio de Janeiro. Libre, 2008.

JACQUES, Heléne. Un Théâtre d'acteurs vidéographiques: Les aveugles de Denis Marleau. Intermedialités: histoire et théorie des arts, des lettres et des techniques, $\mathrm{n}^{\circ} 6$, pág. 79-94, 2005. Québécoise d'études théâtrales.

Projections de la mort. Surdeux mises en scène de Denis Marleau. L'Annuaire théâtral: revue Québécoise d'études théâtrales, n 37, 2005, págs. $113-127$

HACKMAN, Berenice Gonçalves. Fadas e monstros da era digital: um recorte do imaginário. COLÓQUIO - Revista Científica da Faccat - v. 7, n. 1-2, jan./dez. 2009.

ISAACSSON, Marta. Desdobramentos do ator e do personagem pela máscara videográfica. REPERTÓRIO: Teatro \& Dança. Ano 13, Número 14, págs. 30-36. 2010.

ArtCultura, v. 13, nº 23, págs. 08-22, 2011.

JAEGER, Michael. A aposta de Fausto e o processo da Modernidade: figurações da sociedade e da metrópole contemporâneas na tragédia de Goethe. Estud. av. [online], 2007, vol.21, n.59, págs. 309-322. ISSN 0103-4014.

MACHADO, Arlindo. O vídeo e sua linguagem. Revista USP, Brasil, n. 16, pág. 6-17, fev. 1993.

MARTINS, Hermínio. Tecnologia, Modernidade e Política. Revista Lua Nova. São Paulo. Agosto, 1997. N. 40-41.pág.279-322.

MAETERLINCK, Maurice. Um teatro de androides. Trad. MOLER, Lara Biasoli. Pitágoras 500 - vol. 4 - pág. 92. Abr. 2013.

OLIVIER, Aurélie. Petites infamies. Jeu: revue de théâtre, $n^{\circ}$ 133, (4), pág. 121-124, 2009.

PEIXOTO JUNIOR, Carlos Augusto. Sobre corpos e monstros: algumas reflexões contemporâneas a partir da filosofia da diferença. Psicolofia em Estudo, Maringá, v. 15, n-1, pág. 179-187, jan/mar, 2010. 
PICON-VALlin, Béatrice. Os Novos Desafios da Imagem e do Som para o Ator: Em Direção a Um “Superator". Revista Cena. Número 7. Periódico do Programa de PósGraduação em Artes Cênicas. Instituto de Artes - Universidade Federal do Rio Grande do Sul. Tradução: Marta Isaacsson. Artigo originalmente publicado In: Etudes Théâtrales, n.26 de Université de Catholique de Louvain Centre d'Etudes Théâtrales, Louvain-la-Neuve, 2003.

RAMOS, Luis Fernando. Hierarquias do real na mimeses espetacular contemporânea. Revista Presença, v.1, n.1, pág. 61-76, jan.-jun. Porto Alegre, 2011.

RUPRECHT, Alvina. Face à Face avec Denis Marleau. Recherches thèâtrales au Canada, volume 22, $\mathrm{n}^{\mathrm{o}}$ 1, 2001.

SANTAELLA, Lucia. O pluralismo pós-utópico da arte. Revista ARS, v.7, nº 14, pág. 131-151. São Paulo, 2009.

SEMELER, Alexandre Ribas e ROZADOS, Helen Beatriz Frota. Imagem, informação e tecnologia: vídeo digital como objeto de estudo para ciência da informação. Revista Informação \& Informação. Londrina, v. 17 n. 1, p. 78 - 92, jan./jun. 2012.

SIBILIA, Paula. A técnica contra o acaso: os corpos inter-hiperativos da contemporaneidade. Revista Famecos: mídia, cultura e tecnologia. Porto Alegre, v.18, n.3, pág. 638-656, setembro/dezembro, 2011.

TREVIZAM, Matheus. Os "monstros" de Virgílio no livro I das Geórgicas. Revista Fragmentos, número 35, pág75-89. Florianópolis/ jul. Dezembro, 2008.

TRIGO, Isa. Cyborgs e Máscaras. In: Repertório: Teatro e Dança, n. 2. Salvador: UFBA, 1999, págs. 43-53.

VARANDAS, Angélica. A Idade Média e o Bestiário. Medievalista on line. Ano 2 número 2. IEM - Instituto de Estudos Medievais, Lisboa, 2006.

\section{Audiovisual}

TECHNOCALYPS; History Channel (Documentário em 03 capítulos). Aperfeiçoamento Humano. Episódio 1 - Biopoder; episódio 2 - preparando para singularidade; episódio 3 - O messias digital. Direção: Theys Frank, 2006.

ENTREVISTA COM ZYGMUNT BAUMAN. Café Filosófico CPFL; Fronteiras do Pensamento, 2011.

AS TRANSFORMAÇÕES DO MUNDO CONTEMPORÂAEO - Luc Ferry e Jorge Forbes. Café Filosófico CPFL; Fronteiras do Pensamento, 2011.

NOVAS SUBJETIVAÇÕES E O MAL-ESTAR NA CONTEMPORANEIDADE. Joel Birman. Café Filosófico CPFL; Invenção do Contemporâneo [s.d.]. 
O HUMANO DESCARTÁVEL. Eugenio Bucci. Café Filosófico CPFL, 2009.

FOUCAULT, DELEUZE E DERRIDA FRENTE À CRISE. Scarlett Marton. Café Filosófico CPFL; Invenção do Contemporâneo, 2012.

CORPO E SAÚDE NA CONTEMPORANEIDADE. André Martins. Café Filosófico CPFL; O Futuro do Corpo; [s.d.].

A VIDA BIOLÓGICA E A VIDA TECNOLÓGICA: DO SUJEITO CORPORAL AO SUJEITO PÓS-ORGÂAICO. Benilton Bezerra Jr. Café Filosófico CPFL, 2009.

HUMANO, DEMASIADO HUMANO - JEAN-PAUL SARTRE - O CAMINHO PARA A LIBERDADE. BBC, [s.d.].

EU, HUMANO. National Geografic, 2012.

FRANKENSTEIN. Direção James Whale. Estados Unidos, 1931, 70 min, p\&b. Dvd.

DR. JEKILL AND MR. HYDE. Direção: Victor Fleming, 1941, 113 min. p\&b. Dvd 2009.

O GABINETE DO DR. CALIGARI. Direção Robert Wiene, 1919, 51 min., p\&b. Dvd -2008 .

1984. Direção Michael Radford, 1984, 1h53min. Dvd - 2005.

V DE VINGANÇA. Direção: James McTeigue, 2h10min. Dvd - 2006.

A ESPINHA DO DIABO. Direção Guillermo Del Toro, 1h47min. Dvd - 2001. 


\section{ANEXO 1 \\ Descrições sobre a mulher do Malleus Malleficarum}

Demônios têm poderes sobre o corpo e sobre a mente dos homens, somente Deus permite exercê-los (o Diabo aparece como uma espécie de permissionário);

a. Existem bruxas, com ajuda do Diabo, através de um pacto com ele firmado, que são capazes de causar males concretos à humanidade;

b. Deus permite a ação dos demônios como Seus ministros e servos com a finalidade de corrigir, punir e aperfeiçoar o universo;

c. As bruxas e o Diabo trabalham em conjunto;

d. As bruxas são instrumentos humanos e agentes livres. Sua culpabilidade é incontestável;

e. Os demônios exercem seu poder sobre os homens pela lascívia da carne;

f. Os demônios (íncubos) mantêm coito com mulheres devassas, embora não o façam por prazer, envergonhando-se, inclusive, de certos atos sexuais, como a sodomia;

g. Deste contato carnal pode haver a concepção;

h. A bruxaria é praticada principalmente por mulheres, porque são mais fracas na mente e no corpo e porque são mais carnais que o homem;

i. Deus confere à bruxaria um maior poder de atuação sobre o genital, tendo em vista o pecado original;

j. Os pecados das bruxas são mais graves que os pecados dos próprios anjos maus;

k. As bruxas não simplesmente hereges, são apóstatas da fé;

1. De todos os criminosos do mundo, são as bruxas que merecem a mais severa punição, cabendo-lhes a pena de morte, precedida de terríveis torturas, de modo que a danação eterna já tenha lugar nesta vida. 


\section{ANEXO 2}

\section{Freaks - deformidade da diversão}

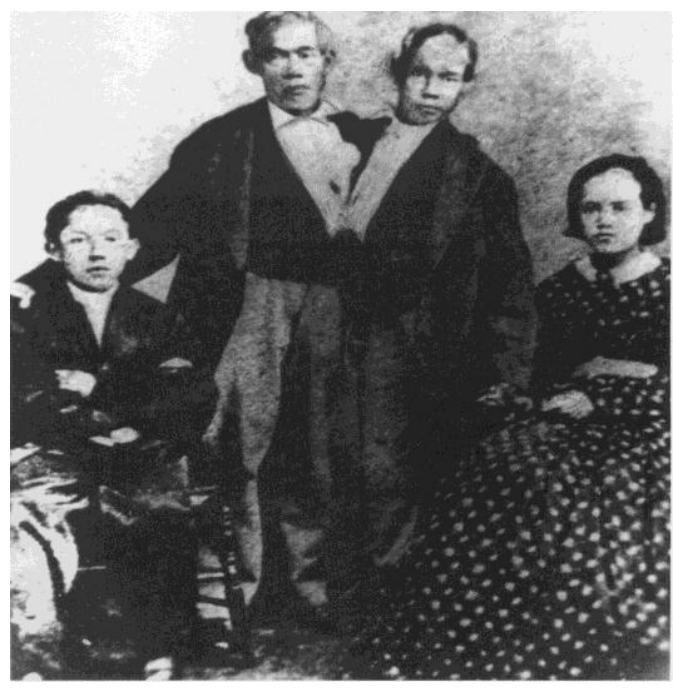

Figura 54 - Nascidos na China, 1811, Eng e Chang Bunker foram os primeiros e os mais famosos gêmeos siameses a atuar no Barnum's Museum. Casaram com duas irmãs: Eng teve sete filhos e cinco filhas e Chang sete filhas e três filhos. Eng e Chang morreram na Carolina do Norte a 23 de janeiro de 1874, com 63 anos. Coleção Akimitsu Naruyama.

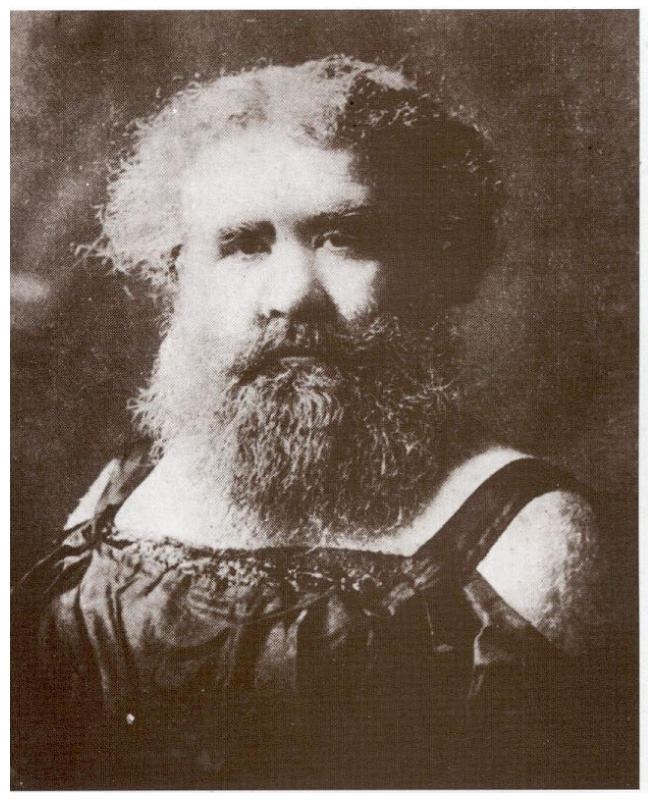

Figura 55 - Grace Gilbert, a mulher barbuda, atuou num espetáculo secundário do Dreamland Circus em Coney Island, Nova Iorque. Foto tirada em 1914.Coleção Akimitsu Naruyama. 


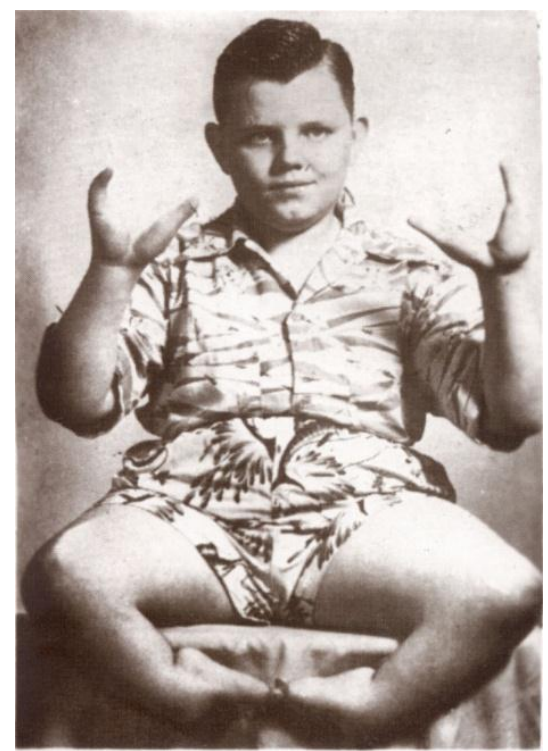

Figura 56 - Grady Stiles, o rapaz-lagosta provinha de uma família cujo os membros sofriam do mesmo problema desde há quatro gerações. Apresentou-se na Feira Estadual de Indianápolis no dia 29 de agosto de 1925. Coleção Akimitsu Naruyama.

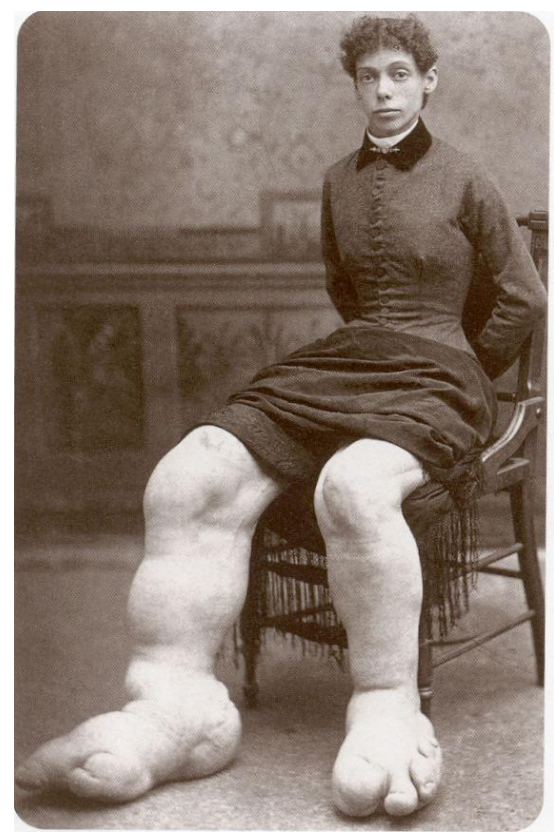

Figura 57 - Fanny Mills, Ohio Big Foot Girl. Nasceu em 1880. Foto tirada em 1904. Coleção Akimitsu Naruyama. 


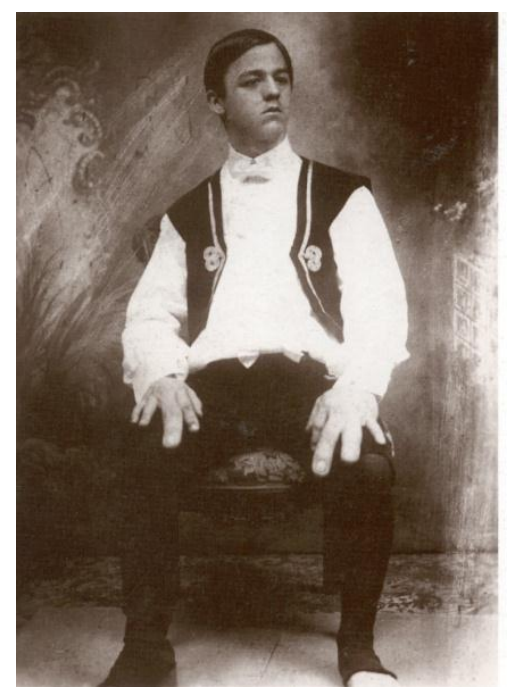

Figura 58 - Joe, o rapaz dos dedos grandes atuou no Colonel Cummin's Wild West Show. Faleceu em 1931. Foto tirada em 1906. Coleção Akimitsu Naruyama.

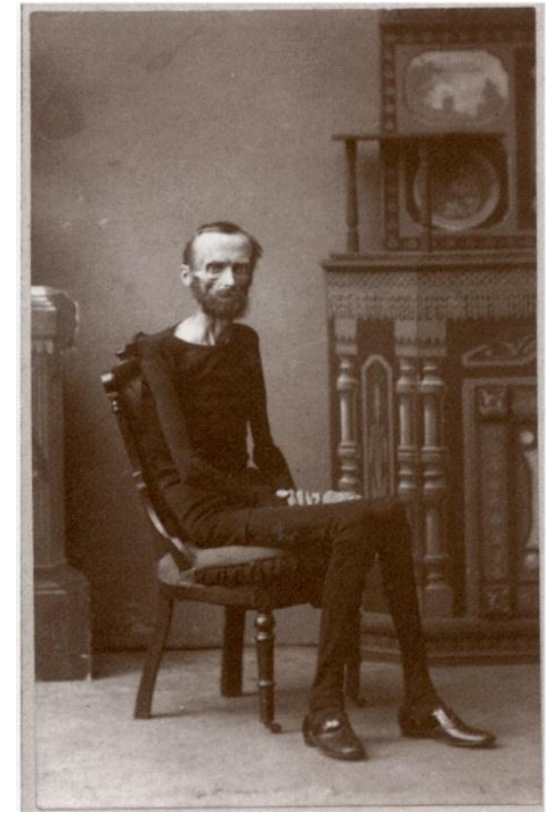

Figura 59 - O máximo que J.D. Avery - o esqueleto-andante pesou em sua vida 27,5 kg. Coleção Akimitsu Naruyama. 


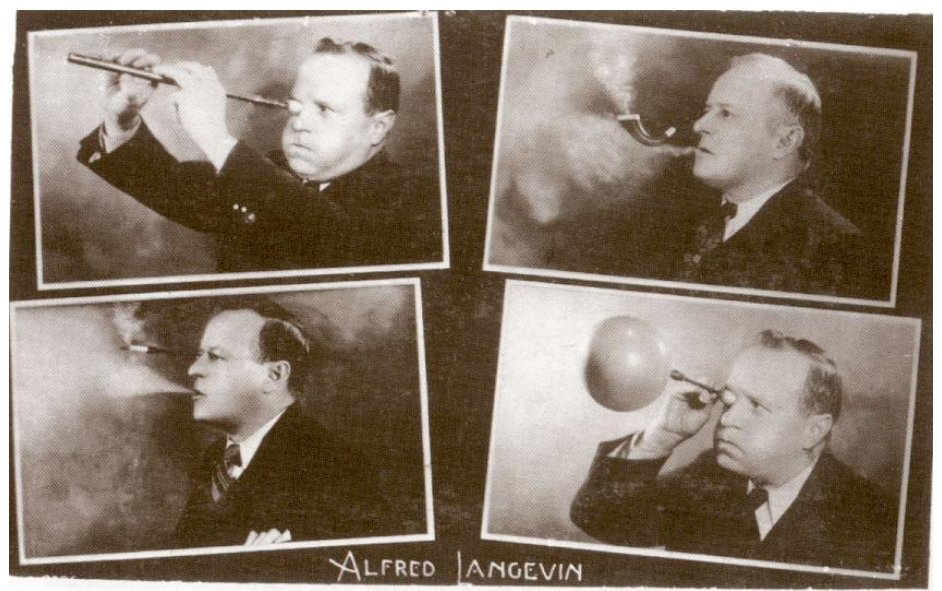

Figura 60 - Alfred Langevin tinha uma aparência normal e sem deficiências visíveis - até começar a inspirar e expirar pelo olho direito. Conseguia inalar o fumo de cigarros pelo olho e expirá-lo pela boca e também não tinha dificuldades em encher um balão com o olho. Coleção Akimitsu Naruyama.

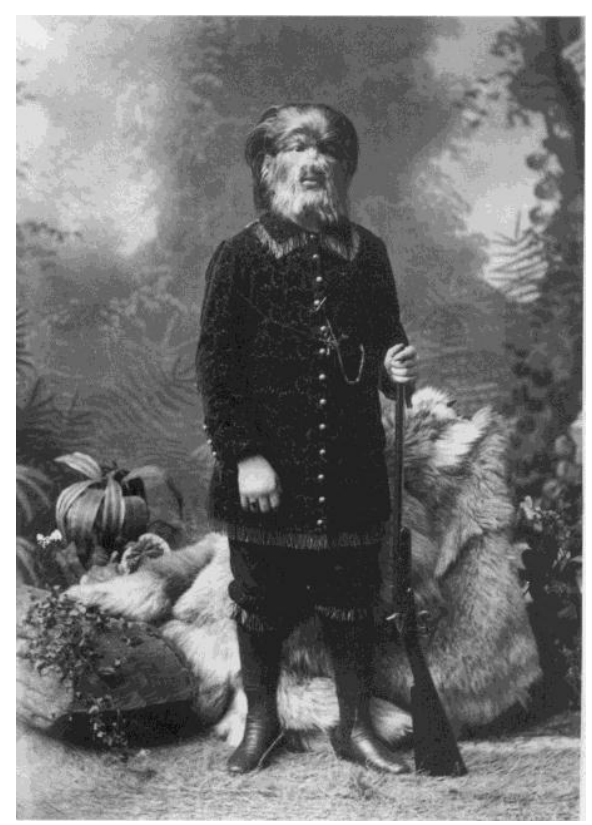

Figura 61 - Jo Jo, o rapaz com rosto de cão, era muito famoso. Todas as 23 sessões que se apresentava por dia esgotavam. Atuou no Barnum's Circus e no Sell Brothers' Circus e em 1891 viajou pela Austrália, durante um ano. Era oriundo da Sibéria, por onde viaja com seu pai, que tinha o mesmo problema. Barnum levou Feodor (seu nome verdadeiro) para a América e inventou uma fascinante história acerca dele. Tinha, supostamente, sido capturado na Rússia, onde vivia nas florestas, comendo pequenos animais. Seu pai era, segundo Barnum, demasiado violento e selvagem para ser capturado. Coleção Akimitsu Naruyama. 


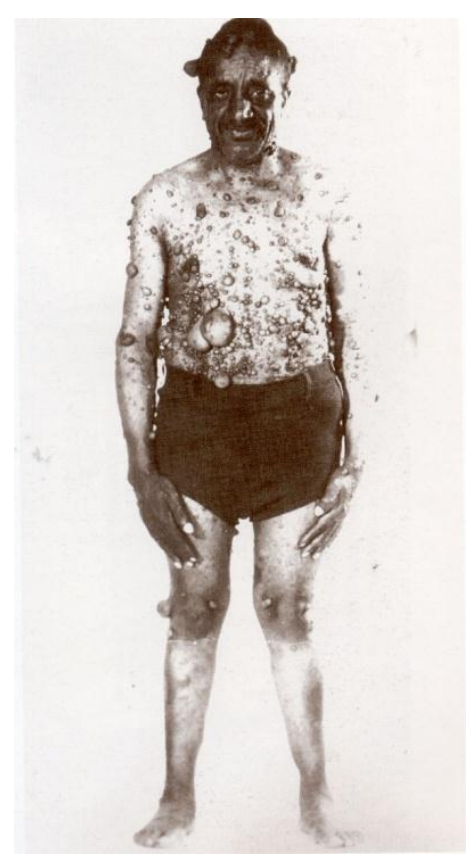

Figura 62 - Homem coberto de bolhas. Atuou no Kraft Show em 1947.Coleção Akimitsu Naruyama.

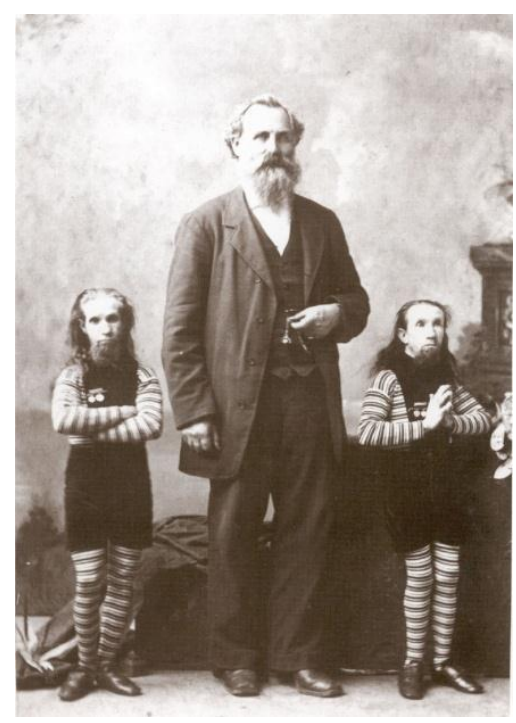

Figura 63 - Waino e Plutano eram os homens selvagens de Bornéu, mas seus verdadeiros nomes eram Hiram e Barney Davis. Apesar de sua pequena estatura e pouco peso - apenas $22 \mathrm{~kg}$ - eram muito fortes e entretinham o público, levantando pesos e membros da audiência. De acordo com a lenda criada por Barnum Courier de 1882, tinham sido capturados pela tripulação de um navio que procurava água potável em Bornéu, depois de uma violenta luta. Sua tribo era supostamente incapaz de falar e se comunicavam através de sons guturais. Eram tão fortes que conseguiam capturar tigres com as próprias mãos. Barney morreu em 1912 e Hiram em 1905. Coleção Akimitsu Naruyama. 


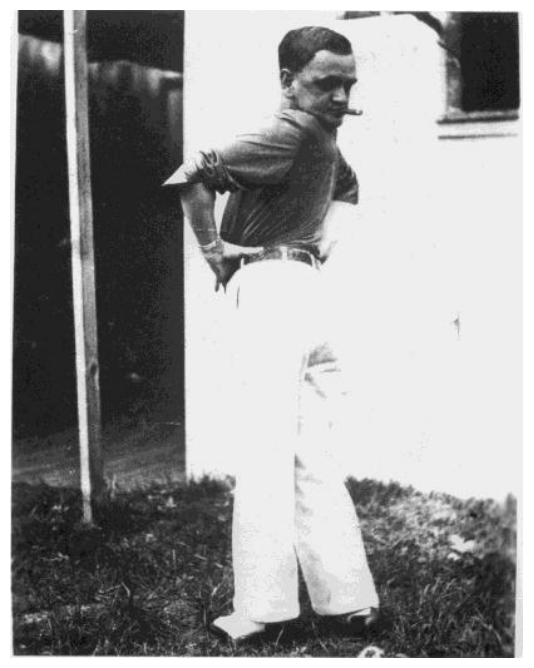

Figura 64 - O Homem Coruja nasceu na Alemanha em 1886 e começou a mostrar a sua bizarra habilidade em apresentações pela Europa no século passado. Segundo ele, sua capacidade de girar a própria cabeça veio com três anos de treinamentos. Em 1921, foi para os Estados Unidos onde se apresentou no Barnum \& Bailey. Além de girar a cabeça, ele também caminhava nessa situação. Em 1940 ele foi fotografado pela revista Life pedindo uma bebida no bar com a cabeça virada para trás. Em 1952 ele apareceu no programa de TV You Asked For It. O alemão, simpatizante do nazismo, morreu 3 anos depois, de ataque cardíaco.

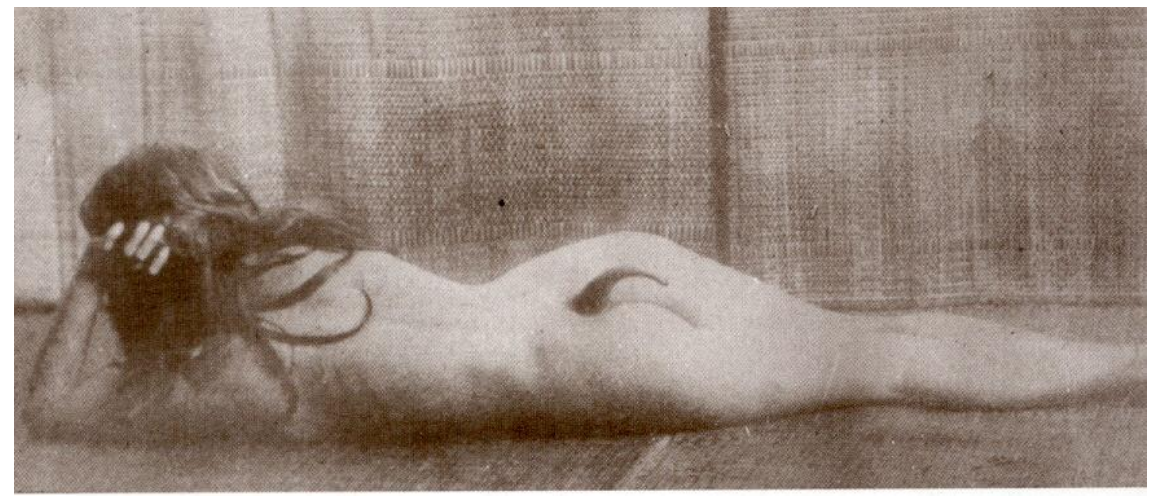

Figura 65 - Stella Blachea, a mulher com cauda, nasceu em Bordéus, na França. Foto tirada quando posava para Adam Forepaugh's Circus com 22 anos. Coleção Akimitsu Naruyama. 


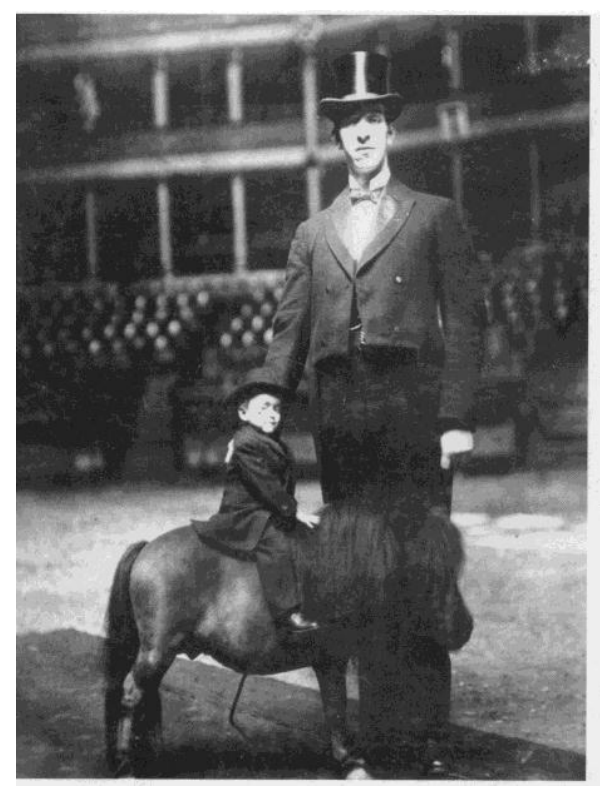

Figura 66 - George Auger, o gigante gaulês e o anão Tom Sordie trabalhavam para o Barnum \& Bailey's Circus. George media 2,59 m de altura e pesava $102 \mathrm{~kg}$. Faleceu no dia de Ação de graças em 1922, aos 36 anos. Quando foi fotografado Tom tinha 25 anos e $71 \mathrm{~cm}$ de altura. Coleção Akimitsu Naruyama.

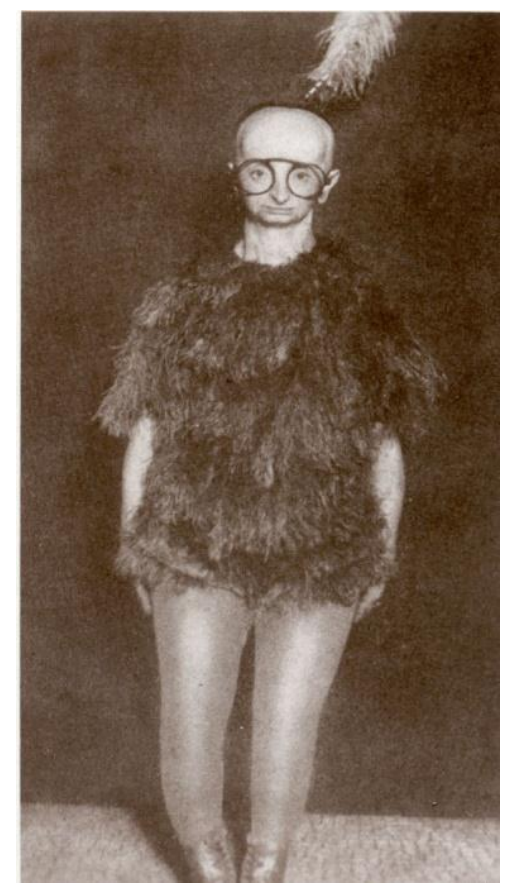

Figura 67- Koo Koo, a mulher-pássaro. Foto tirada em 1937 durante as gravações do filme: A Parada dos Monstros. Tal qual outras aberrações, Koo Koo trabalhou para vários circos, mas ficou mais tempo com o Ringling Brothers' Circus. 


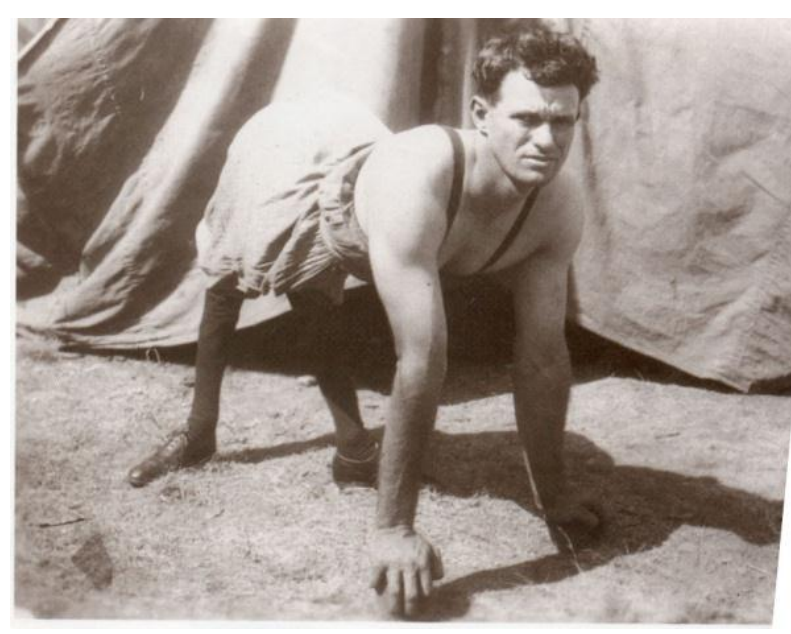

Figura 68 - O rapaz-cavalo trabalhava no Tom Mix Circus e nos espetáculos secundários de Ted Metz. Coleção Akimitsu Naruyama.

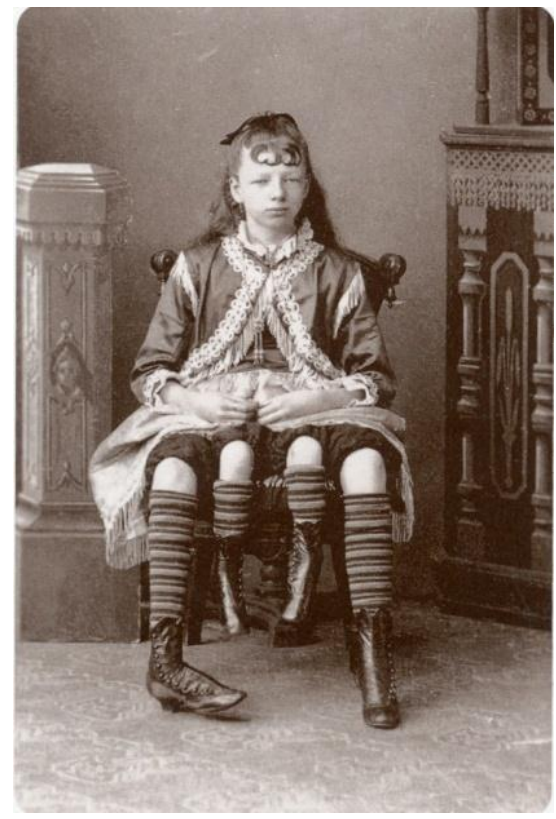

Figura 69 - Myrtle Corbin, a mulher com quatro pernas nasceu em Claubourne, no Texas e tinha dois corpos distintos a partir da cintura para baixo. Esta fotografia foi tirada quando tinha cerca de 15 anos. Casou-se e teve quatro filhas e um filho; três crianças nasceram de um corpo e as outras do outro. Myrtle atuava no Barnum \& Bailyes's Circus e faleceu em 1927. Coleção Akimitsu Naruyama. 


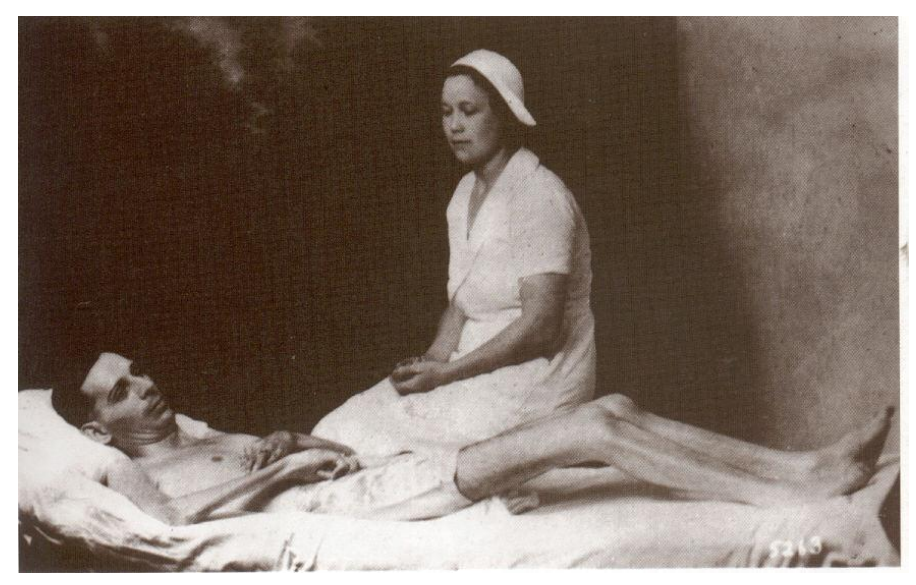

Figura 70 - John Shouse, o homem-petrificado, nasceu em Oklahoma. Seus ossos petrificaram e só conseguia mexer a boca para beber. Esta foto, que mostra sua mulher, foi tirada quando tinha 35 anos. Sua enfermeira afirmava que se alguém lhe batesse, Shouse despedaçar-se-ia como um vaso de porcelana sobre o chão de mármore. Coleção Akimitsu Naruyama.

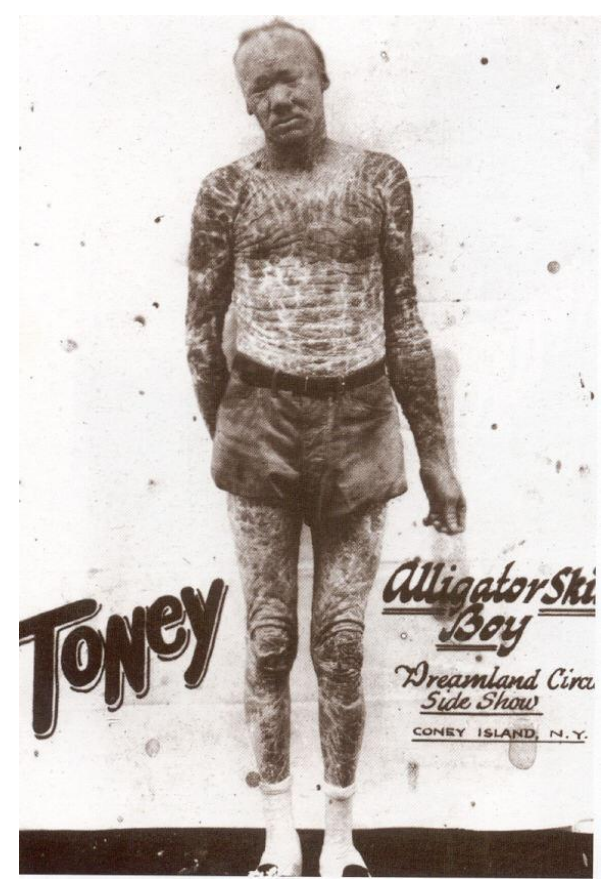

Figura 71 - Toney, o rapaz com pele de crocodilo atuou num espetáculo secundário do Dreamland Circus, em Coney Island, Nova Iorque em 1915. Coleção Akimitsu Naruyama. 


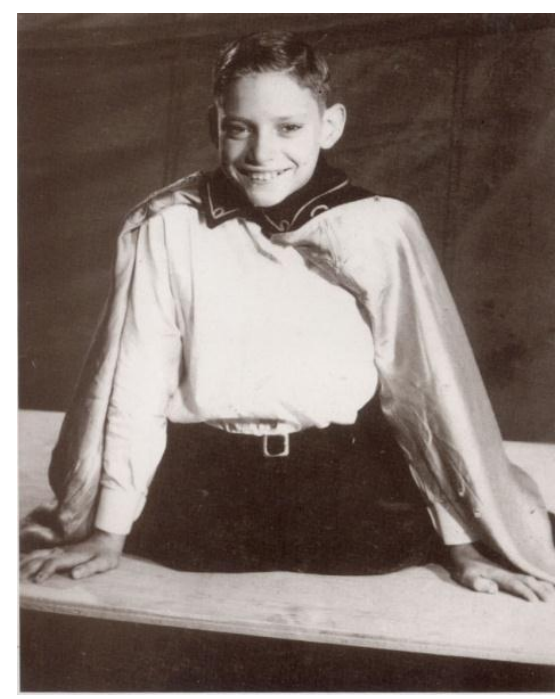

Figura 72 - Wesley Uppaman, nascido em Greenville, na Carolina do Norte, andava sobre suas mãos durante as apresentações. Em 1949 viajou com o Clyde Beatty's Circus. Coleção Akimitsu Naruyama.

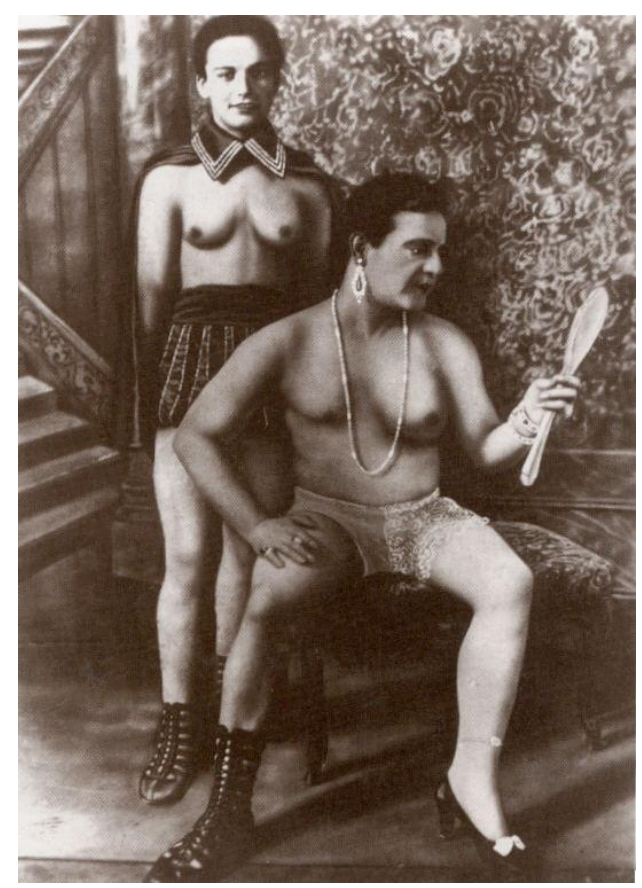

Figura 73- Alberta e Alberta Karas nasceram na França. Seu caso é tido como o primeiro na história da medicina de duas pessoas com os dois conjuntos genitais (nascidos de pais normais). O que está de pé comportava-se como homem, mas a metade superior do seu corpo era feminina e a inferior; masculina. O que está sentado comportava-se como uma mulher, mas tinha um lado feminino e outro masculino. A face feminina nunca precisava ser barbeada e tinha uma maça do rosto mais alta do que a do lado masculino. O braço e a perna do lado feminino também eram cerca de $5 \mathrm{~cm}$ menores do que o lado masculino. Usava sapatos especiais para não mancar. Coleção Akimitsu Naruyama. 


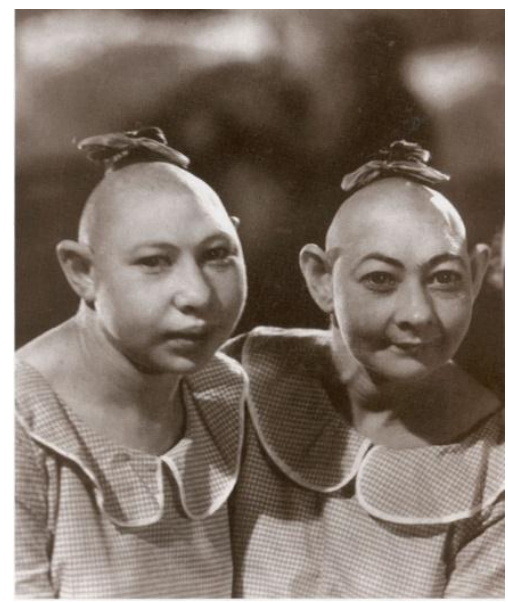

Figura 74 - Crianças astecas de cabeças pontiagudas. Eram oriundas da Austrália e atuaram no Ringling Brothers' Circus durante 30 anos. Coleção Akimitsu Naruyama.

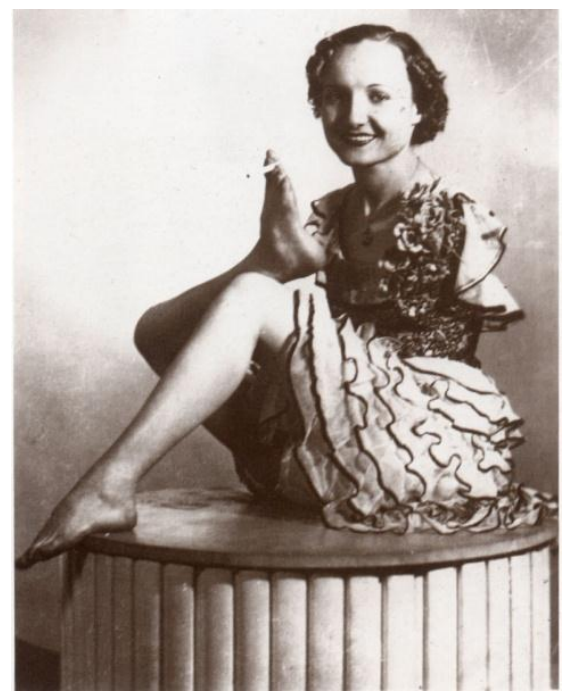

Figura 75 - Frances O'Connor, a maravilha sem braços, nasceu dia 14 de abril de 1917 em Sheridan, no Wyoming. Era especialmente conhecida por segurar um revólver com um pé e puxar o gatilho com o outro, mas também não tinha dificuldades em fumar um cigarro. Foto tirada em 1941, quando tinha 24 anos. Coleção Akimitsu Naruyama. 


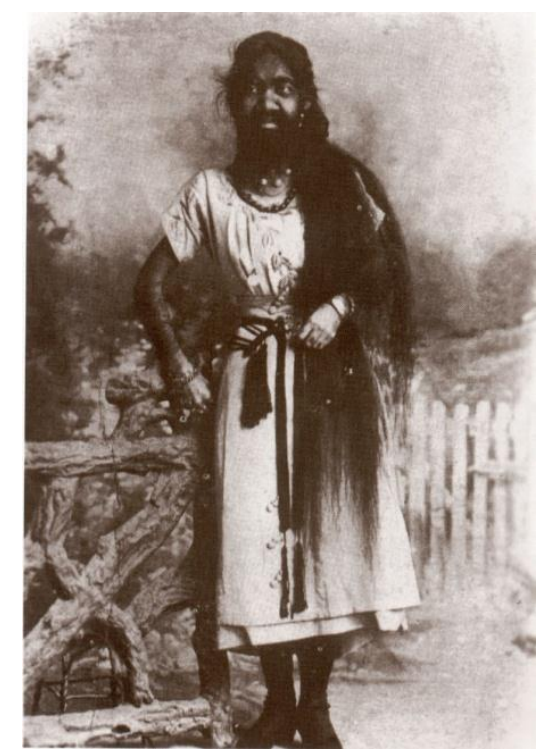

Figura 76. Krao, a mulher elo perdido foi encontrada no Laos, pelo famoso caçador de talentos do Médio Oriente A. Farini. Krao estava completamente coberta de cabelo, tal como seus pais e diz-se que tinha muitas características dos macacos. Fez sua primeira apresentação aos sete anos e foi adotada por uma família berlinense. Doou dinheiro à caridade, falava várias línguas e tinha uma voz maravilhosa. Ela não tinha contato com os outros artistas, a não ser durante os espetáculos, e mesmo durante estes, preferia estar com hamsters e canários. Foto tirada em 1924, quando trabalhava para Ringling Brothers' Circus. Coleção Akimitsu Naruyama. 